\title{
ENERGY DIVISION \\ ANNUAL PROGRESS REPORT \\ For Period Ending September 30, 1983
}

\author{
W. Fulkerson, Director \\ T. J. Wilbanks, Associate Director and Senior Planner
}

H. E. Zittel, Section Head, Environmental Impact Section

R. M. Davis, Section Head, Regional and Urban Sturlies Section

R. B. Shelton, Section Head, Economic Analysis Seriion

A. S. Loebl, Section Head, Data and Analysis Section

J. W. Michel, Section Head, Efficiency and Renewables Research Section

Date Published-June 1984

Prepured by the

OAK RIDGE NATIONAL LABORATORY

Oak Ridge, Tennewee 37831

operated by

MARTIN MARIETTA ENERGY SYSTEMS, INC.

for the

U.S. DEPARTMENT OF ENERGY

under Contract No. DE-ACO5-840R21400 


\section{Contents}

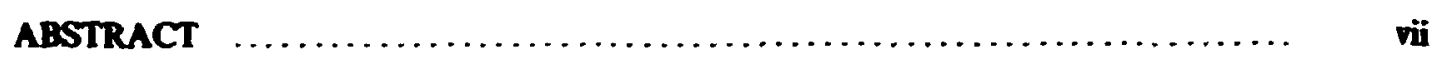

1. INTRODUCTION AND EXECITTIVE SUMMARY $\ldots \ldots \ldots \ldots \ldots \ldots \ldots \ldots$

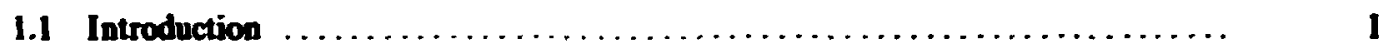

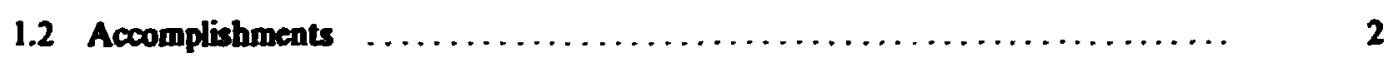

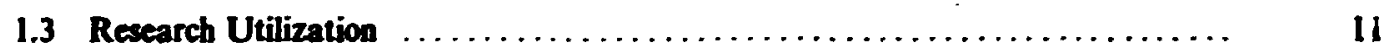

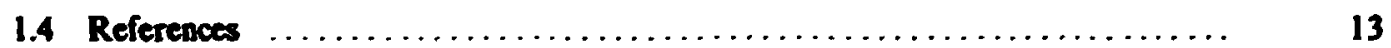

2. ENVIRONMENTAL IMPACT SECTION $\ldots \ldots \ldots \ldots \ldots \ldots \ldots \ldots \ldots \ldots \ldots \ldots \ldots \ldots \ldots$

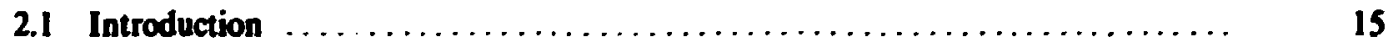

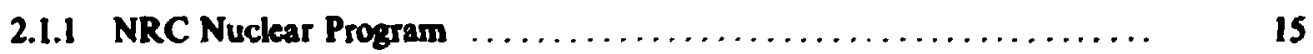

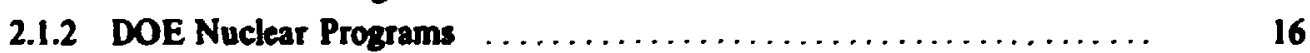

2.1.3 Foasil Energy and Conservation and Renewables Programs ........ 17

2.1.4 Integrated Ascessments Group ............................. 19

2.1.5 Applied Physical Sciences Group $\ldots \ldots \ldots \ldots \ldots \ldots \ldots \ldots \ldots \ldots . . \ldots$

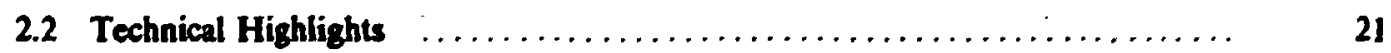

2.2.1 Use of DOE Site Selection Criteria for Screening Low-Level

Waste Disposal Sites on the Oak Ridge Reservation .............. 21

2.2.2 A Model for Groundwater Seepage from Mill Tailings Ponds ........ 23

2.2.3 Une of Electromagnetic Terrain Conductivity Measurements to Map Liquid Hazardous Waste Migration in Groundwater ........ .. 24

2.2.4 National Inventory of Abandoned Mine Land Problems ............. 24

2.2.5 Evaluation of Dispersion Models for Use in Emergency Response Situations ....................... 26

2.2.6 Environmetal Analysis of the Operation of ORNL .............. 27

2.2.7 Methodology for Estimating Fisheries Hharveat $\ldots \ldots \ldots \ldots \ldots \ldots \ldots .28$

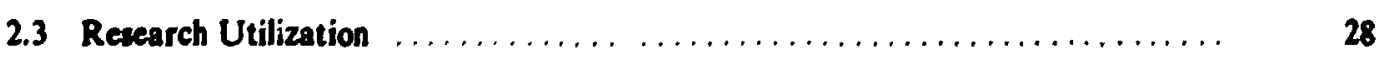

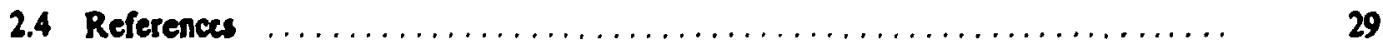


3. REGIONAL AND URBAN STUDIES SECTION $\ldots \ldots \ldots \ldots \ldots \ldots \ldots \ldots \ldots \ldots$

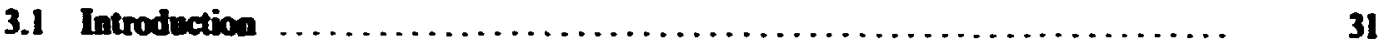

3.2 Social Analysis and Aswermeat Highlights .................... 33

3.2.1 Reatarting Three Mile Island Unit 1: Social and

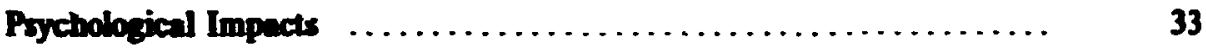

3.2.2 Energy-Related Inventions Program $\ldots \ldots \ldots \ldots \ldots \ldots \ldots \ldots \ldots . . . \ldots \ldots$

3.3 Resource Amalysis and Mineral Aswessueat Highlights ................. 37

3.3.1 Winerals Valuation for Royalty Purpoes .................. 37

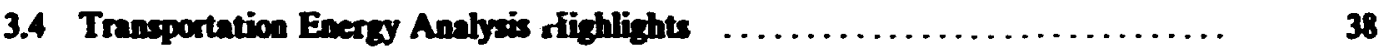

3.4.1 Intermediate Future Forecasting System:

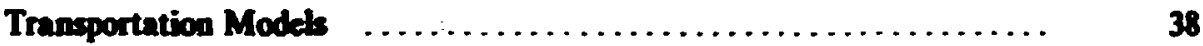

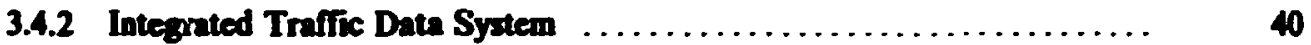

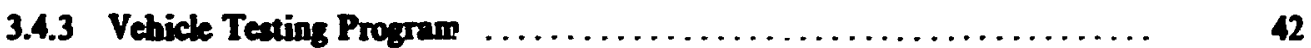

3.4.4 Gasoline and Diesel Fuel Forecast ........................ 45

3.5 Emergency Planning Highlights $\ldots \ldots \ldots \ldots \ldots \ldots \ldots \ldots \ldots \ldots \ldots \ldots \ldots \ldots \ldots$

3.5.1 Hazard Mitizution Potential of Earth-Sheltered Residences .......... 46

3.5.2 Improved Robotic Equipment for Radiological Emergencies .......... 49

3.5.3 Emergency Planning for Reactor Sites ....................... 49

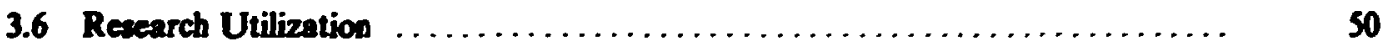

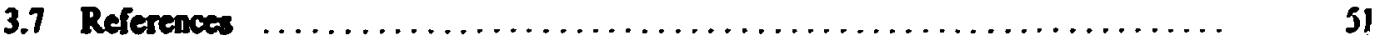

4. ECONOMIC ANALYSIS SECTION $\ldots \ldots \ldots \ldots \ldots \ldots \ldots \ldots \ldots \ldots \ldots \ldots \ldots \ldots$

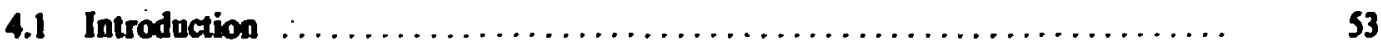

4.1.1 Energy and Technology Group $\ldots \ldots \ldots \ldots \ldots \ldots \ldots \ldots \ldots \ldots \ldots, 53$

4.1.2 Resource and Environmental Analysis Group $\ldots \ldots \ldots \ldots \ldots \ldots \ldots .54$

4.1.3 Energy Demand Modeling Program $\ldots \ldots \ldots \ldots \ldots \ldots \ldots \ldots \ldots . \ldots \ldots$

4.1.4 Uranium Industry Analysis Program $\ldots \ldots \ldots \ldots \ldots \ldots \ldots \ldots \ldots . \ldots 7$

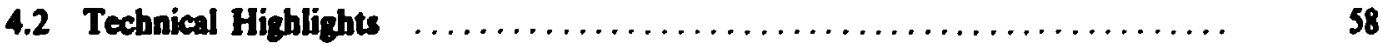

4.2.1 Clinch River Dreeder Reactor: An Asecesment of Need

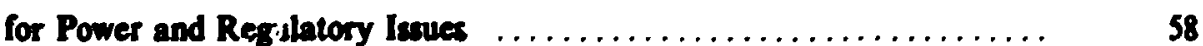

4.2.2 Short-Rotation Woody Crops Progran $\ldots \ldots \ldots \ldots \ldots \ldots \ldots \ldots \ldots .61$

4.2.3 Optimal Stockpiling $\ldots \ldots \ldots \ldots \ldots \ldots \ldots \ldots \ldots \ldots \ldots \ldots, 64$

4.2.4 Pricing Cogenerated Electricity .......................... 64

4.2.5 Simulation of Libsrian Esergy Demand ........................ 67

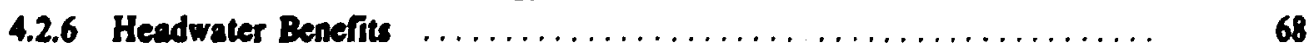

4.2.7 End-Use Models $\ldots \ldots \ldots \ldots \ldots \ldots \ldots \ldots \ldots \ldots \ldots \ldots \ldots \ldots \ldots, 69$

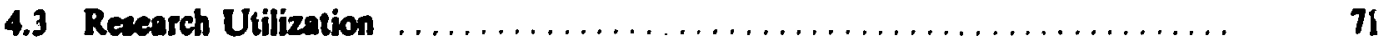

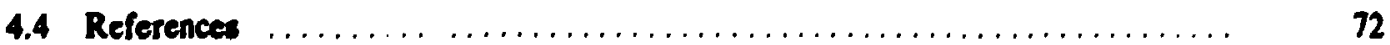




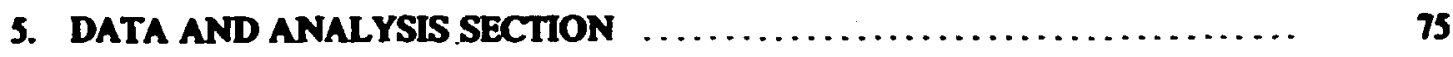

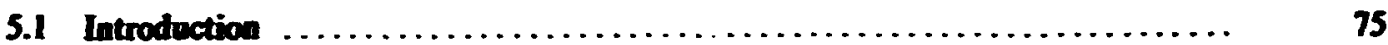

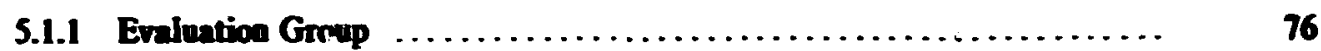

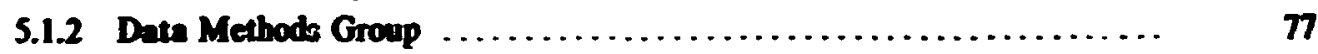

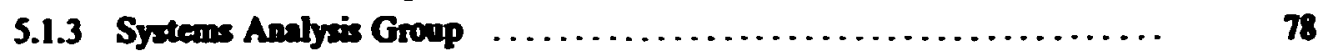

S.1.4 Syzems Development Group $\ldots \ldots \ldots \ldots \ldots \ldots \ldots \ldots \ldots \ldots \ldots \ldots$. 9

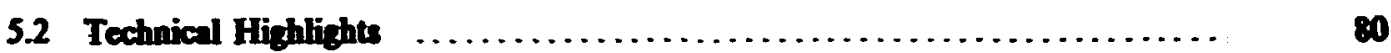

5.2.1 Evaluation of Home Eaergy Aulit and Loas Programs ............ 80

5.22 Alternate Fueb Information Requirements Review .............. 84

5.2 .3 Nuclear Information Requivernents Reviev ................... 85

5.24 Petroleum Supply Interruption Stadies ..................... 86

5.2.5 Major Item Syatem Mapping (MISM) Project for the U.S. Army Materiel Development and Readinew Command ............. 89

5.26 Aircrew Automated Bscape Syatems ........................ 91

5.2. Project to Enhance the Accescibility and Avilability of the Logintics Intelligence File for the U.S. Army

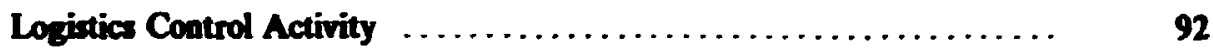

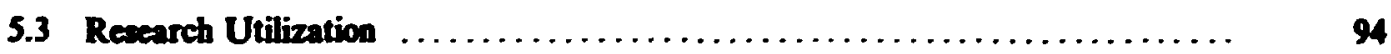

5.3.1 Evaluation Group $\ldots \ldots \ldots \ldots \ldots \ldots \ldots \ldots \ldots \ldots \ldots \ldots \ldots \ldots \ldots$

5.3.2 Systems Analysis Group $\ldots \ldots \ldots \ldots \ldots \ldots \ldots \ldots \ldots \ldots \ldots \ldots$

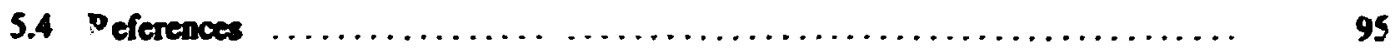

6. EFFICIENCY AND RENEWABLES RESEARCH SECTION ............ 97

..I Introduction .......................................... 97

6.1.1 Section Overview ................................. 97

6.1.2 Building Equipment Recearch Program .................... 98

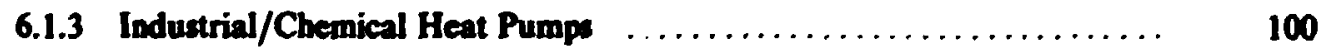

6.1.4 Power Systems Technology Program ........................ 100

6.1.5 Building Thermal Envelope Systems and Insulating Materials Program ............................... 102

6.1.6 Residential Conservation Service Program $\ldots \ldots \ldots \ldots \ldots \ldots \ldots \ldots .103$

v.1.7 Work for Other Government Agencies .................... 104

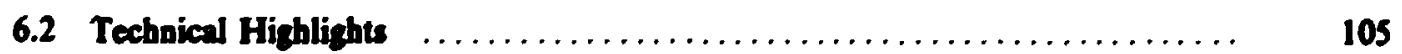

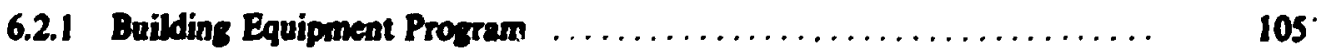

6.2.2 Induatrial/Chemical Heat Pumps $\ldots \ldots \ldots \ldots \ldots \ldots \ldots \ldots \ldots . \ldots \ldots$

6.2.3 Power Systems Technolozy Progrom .......................... 114

6.2.4 Buildios Thermal Envelope Sytems and Insulatiog Materials ........ 117

6.2.5 Recidential Conservation Service $\ldots \ldots \ldots \ldots \ldots \ldots \ldots \ldots \ldots \ldots . \ldots \ldots$

6.2.6 Work for Other Government Agencies .................... 124

6.3 Rewearch Utilization $\ldots \ldots \ldots \ldots \ldots \ldots \ldots \ldots \ldots \ldots \ldots \ldots \ldots \ldots \ldots \ldots, 127$

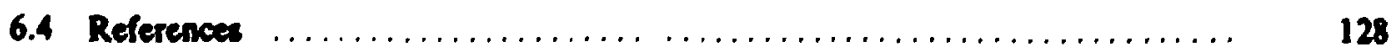




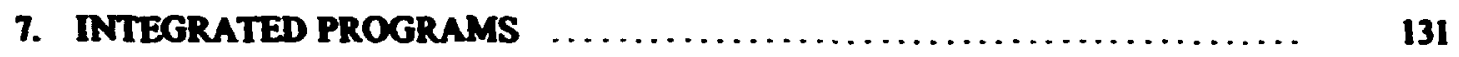

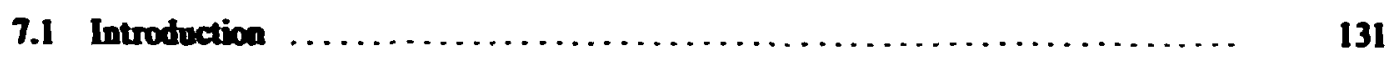

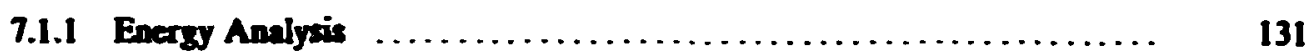

7.1.2 Emergency Preparedeess .............................. 132

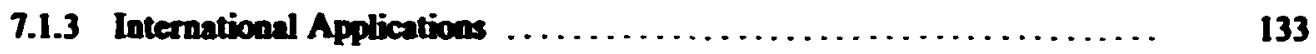

7.1.4 Specia' Studies ................................ 133

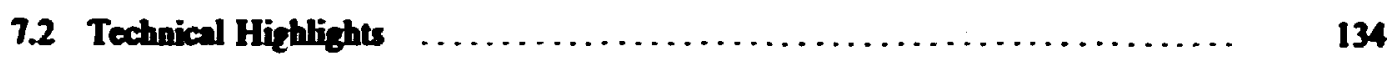

7.2.1 Aseanent of Energy Options for Liberia ................. 134

7.22 When Will the Next Energy Crisis Occur? ................. 135

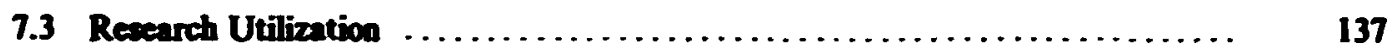

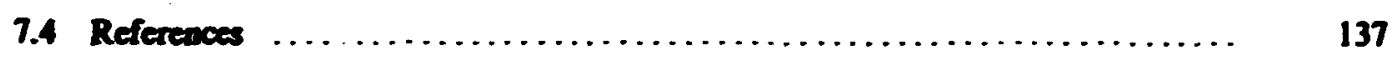

8. PUBLICATIONS, PRESENTATIONS, AND PROFESSIONAL

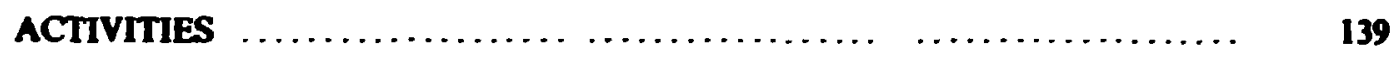

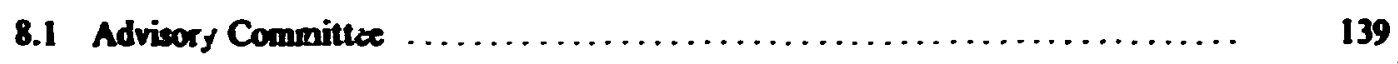

8.2 Publications by Energy Division Staff ........................ 139

8.3 Enviroamental Impact Statements and Assessments ................ 153

8.4 Presentations by Energy Division Staff $\ldots \ldots \ldots \ldots \ldots \ldots \ldots \ldots \ldots \ldots \ldots$

8.5 Professional Activitics and Awards $\ldots \ldots \ldots \ldots \ldots \ldots \ldots \ldots \ldots \ldots \ldots, \quad 162$

8.6 Workshops and Symposia Organized by

8.7 Energy Division Consultants and Subcontractors $\ldots \ldots \ldots \ldots \ldots \ldots \ldots \ldots \ldots, \quad 166$

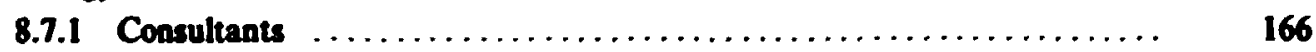

8.7.2 Subuontractors by Company $\ldots \ldots \ldots \ldots \ldots \ldots \ldots \ldots \ldots \ldots \ldots, 167$

8.8 Publications by Subcontractors $\ldots \ldots \ldots \ldots \ldots \ldots \ldots \ldots \ldots \ldots \ldots \ldots \ldots, 168$

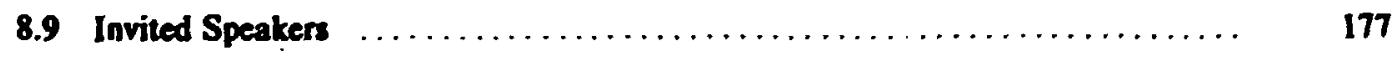

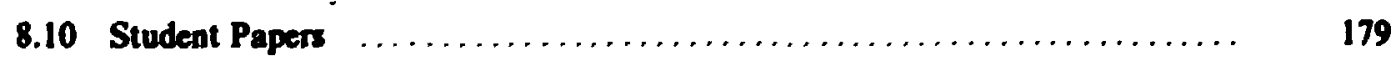

8.11 Financial Statement and Personnel Summary $\ldots \ldots \ldots \ldots \ldots \ldots \ldots \ldots .179$ 


\section{Abstract}

This report covers wort done during FY 1983 by the stafi of the Enexs Dividion and its sebcontractors and by colleagues in other Oak Ridge National Laboratory dividions morting on

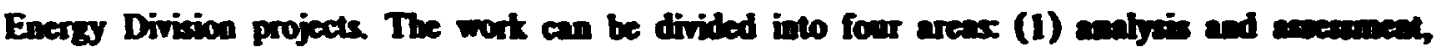
(2) modek and data systems, (3) research to improve the efijicacy of enersy we and to improve electric power transmiasion and distribution, and (4) rescarch utilization. Sepport cane priacipally from the U.S. Department of Energy (DOE), the U.S. Nuchar Regulatory Comminsion, and the U.S. Department of Defense, tut also from a number of other asencies and organizations.

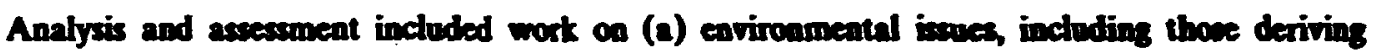
from the preparation of enviroamental impect statements; (b) energy and resource analycis and (c) emergency preparedness. Environmental statement sctivity dectined in FY 1983, and research on the siting of repositories for low-level redionctive waste and on the detection and modeling of leachate from existing hazardous waste disposal sites increased. Enerzy and resource analysis included completing wort with the Liberian government to develop an energy policy for that country, evaluating the effectiveneas of government and utilty energy conservation programs, developing methods for valuing fuel mineral deposits on federni land, and forecanting gasolise and diesel fuel demand. Emergency preparedness research involved studies on nuclear reactor sceident contingency planning, on the feasibility of earth-sheltered bousing for diaster mitigation, on electromagnetic polse effects on the electric power grid, on optimum oil stockpiliag, and on fuetswitching capability.

The models and data syatems area involved recearch on cvaluating and developing esiersy. environment, and engineering simulation models and on devising large data management systems, evaluating user data requirements, and compiling data basea. In the modeling work, codes were developed to simulate transport of pollutants in porous media; atmospheric dieperion models for use in energency situations were evaluated; models for forecanting exersy demand in the transportation and recidential sectors were improved; a model was developed to analyze the cont of fuel from woody biomass plantations; experiments were conducted to develop data for a rehicke fuel simulator, and a model to simulate emergency ejection systems for military arreraft was documented and improved. The data systems area is growing rapidly and in FY 1983 involved, for example, completing an inventory of abandoned coal mine problems throughout the United Statex, analyzing user data requirements related to renewable fuels and the auclear indianry, and development of a user-friendly traffic data bese management sybtem for city traffic engineers.

Research on improving the efficiency of energy use was focused primarily on the buildinas and electricity sectors. A major effort on heat pump technology, which includes both beat-activated and electrically driven systems, entinues. Under subcontract, Weatinghouse has developed a two-speed air-to-air heat pump with an annual performance fector that could be as high as 2.7. Simulation 
modeting indicates that oven that could be improved. High coeficicats of performence were abo

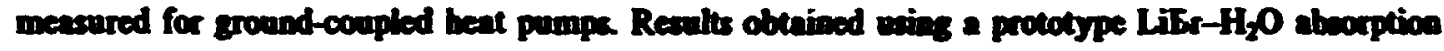
heat pamp showed $t^{\prime}$ :at industrial wate heat conld be upgraded to weful temperatures and that the covomics bok promisine. Experiments were largeb completed on the efiects of thermal mass in

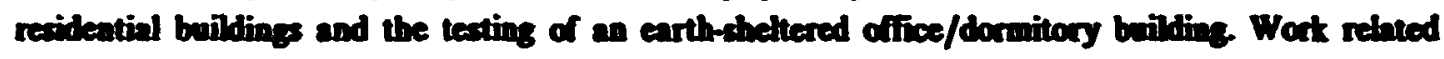
to power systems inclucied contined progress on the Athens, Tenuences dietribution antomation and control experiment, analysis of the problems involved with dipened ceneratiog cources sach as

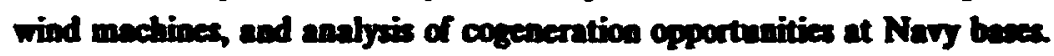

An important expect of all the work wes research utilizntion. Since the Enersy Divition is doing applied research, results are, by definition, intended to solve problems or answer quections of

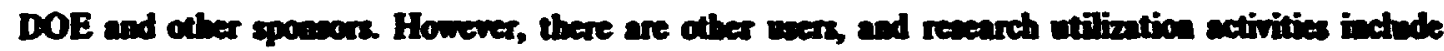
technolos trander, commercialization efforts, ontreach to state and regional orgaizations, and of conses ivformation discemiantion. 


\section{; \\ 1. Introduction and Executive Summary}

William Fulkerson

\subsection{INTRODUCTION}

The Energy Division is one of fffeen research divisions at Oak Ridge National Lal-. ratory (ORNL). It was extablished in 1974 to bring together (1) wort on environmental, technological, and regional ascesements related to exergy development and (2) research on energy demand analycis and on improving the efficiency of energy use and conversion (energy conservation). Because of this broed scope, the staff of the Division has atways been multidisciplinary. During FY 1983, scientific and technical profescionals numbered 133, including 54 engineen, 38 physical and life scientists, and 41 social scientists. The Division is the "home" for mot of the practicing social scientists at ORNL, many of whom are coonomists and geographers, although there are also political scientists, sociologists, psychologists, demographers, and others.

The work of the Division is carried out not only by its own staff, but also by subcontractors and colleagues in other ORNL divisions, including Environmental Sciences, Health and Safety Research, Instrumentation and Controls, Engineering Technology, Metals and Ceramics, Fusion Energy, Computer Sciencex, Engineering, and Information. During FY 1933, more than half the budget was spent by subcontractors, including a large number of universities and private firms. The list of subconaractors (Sect. 8.7) shows the range of institutions involved.

This tenth annual report of the Division covers work done during FY 1983 (October I, 1982. through September 30,1983$)$. As with these documents in the pact, ${ }^{1 \rightarrow}$ the format follows approximately the organizational structure of the Energy Division. Chapters 2 to 6 summarize the activities of the rections of the Division: Environmental Impact Section, headed by H. E. Zittel; Regional and Urban Studies Section, R. M. Davis; Economic Analyzis Section, R. B. Shelton; Data and Analysis Section, A. S. Loebl; and Efriciency and Renewables Research Section, J. W. Michel. In addition, work on a variety of projects that cut acroes section lines is reported in Chap. 7 , Integrated Programs. These activitie are under the supervision of T. J. Wibanks, Associate Director of the Division.

During FY 1983, the research efforts were supported primarily by the U.S. Department of Energy (DOE) (75\% of expenditurea), along with a wide variety of other federal agencies, principal among which were the U.S. Nuclear Regulatory Commiscion (NRC) and the U.S. Department of Defenec (DOD). Important support also came from the U.S. Department of the Interior (DOI), the Agency for I.ternational Development (AID) of the U.S. Department of State, the U.S. Department of Transportation (DOT), the Federal Emergency Management Agency (FEMA), the U.S. Department of Justice, the U.S. Environmental Protection Azency, the Tennesuce Valley 
Authority (TVA), and the Synthetic Fuels Corporation. Within DOE, support came from five assistant secretaries (Conservation and Renewable Energy; Fossil Energy: Environmental Protection, Safety and Emergency Preparedness; Energy Research; and Nuctear Energy) and also from the Energy Information Administration (EIA); the Economic Regulatory Administration; the Office of Policy, Planning and Analysis (now Policy, Safety and Environment); the Federal Energy Regulatory Commission; the Oak Ridge and San Francisco Operations Offices, and from other DOE national laboratories. Work was also supported by the Electric Power Research Institute, Bonneville Power Administration, and the Clinch River Breeder Reactor Project office. A summary of expenditures for each sponsor is given in Chap. 8.

\subsection{ACCOMPLISHMENTS}

The work of the Division is very diversified, but it can be divided into three major categories: analysis and assessment, models and data systems, and technology development. Analysis and assessments contribute information on ir tant energy issues and on policy and technological alternatives, identify research and developm:nt (R\&D) needs, and help to set R\&D priorities. The primary foci during FY 1983 were on (1) environmental issues, including those related to the preparation of environmental statements and assessments and those involving the operation of the Laboratory itself; (2) energy and resource analysis, which ranged from hilping the Liberian government develop an energy strategy to evaluating the effectiveness of various government and utility energy conservation programs; and (3) emergency preparedness, which included work on reactor accident response planning, uses of earth-sheltered housing for civil defense, optimum petroleum stockpiling, and analyzing the chances of another oil crisis.

Work on models and data systems involves research to develop tools and methods useful in analysis and assessment and in decision making. It includes development and evaluation of environmental models, models for energy demand forscasting, and models for projecting the economics of energy technologies (e.g., plantations for growing biomass fuel). Data systems R\&D is a growing area deriving largely from our efforts for the EIA, but increasingly the work is being supported by other agencies, including DOT and DOD. Past activities have emphasized evaluating the quality, relevance, and limitations of data systems and assessing user data requirements and needs. The work for DCD includes these activities but is focused on developing advanced data systems to support decisioi, making and problem solving. These systems are designed to take advantage of rapidly evolving computer hardware and software, including state-of-the-art data base management approaches.

Technology development activities of the Division principally involve research on improving the efficiency of energy end use, particularly in buildings, and research on electricity transmission, distribution, and end use. Work on heat pumps, including electric-driven as well as heat-activated systems, is a specialty. It includes applications ranging from heating and cooling residential and commercial buildings to upgrading low-temperature reject heat for industrial process applications. Research is also under way on improving building thermal envelopes and on diagnosing building energy performance and evaluating the cost-effectiveness of retrofit measures to upgrade the existing stock of buildings. Technology development also encompasses power systems $R$ \&D, which involves work on the electric distribution and transmission system. Projects include a large-scale experiment on distribution automation and load control at Athens, Tennessee; analyzing problems involved with incorporating dispersed generating sources into the grid; work on improving high- 
voltage transmission system hardware; and investigations of the system effects of electromagnetic pulses from nuclear explosions.

Significant accomplishments for FY 1983 in each of these three areas (analysis and assessment, models and data systems, and technology development) are summarized in Table 1.1. Each item includes a reference to the relevant section in the body of the report.

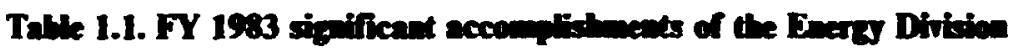

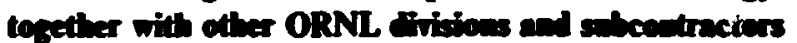

\section{ANALYSIS AND ASSESSMENT}

A. Environmental lesues

- Six environmental impact statements (EISs) and assessments were completed. This represents the first significant decrease in this work since ORNL became involved with writing National Environmental Policy Act (NEPA) documents in 1972. Nevertheless, the staff was involved in important and interesting cases, such as the preparation of a generic EIS for the national magnetic fusion program (Sect. 21.2) and, in collaboration with Argonne National Laboratory, an EIS for : very large hydroelectric project on the Susitna River in Alaska (Sect. 2.1.5).

- Approximately 30 environmental monitoring plans for pruposed synfuel projects were critically reviewed as part of DOE assistance to the Synthetic Fuels Corporation. Additionally, lessons learned about surface water and air quality impacts at direct coal liquefaction pilot plants were revealed by careful analysis of available data. (Sect. 2.1.3)

- DOE site selection triteria were applied to the identification and ranking of five candidate areas for the siting of a new low-level radioactive waste disposal repository on the Oak Ridge Reservation. Site deficiencies, which must be considered and addressed in the design of a facility, were clearly identified as a result of using the site selection criteria. (Sect. 2.2.1)

- Electromagnetic conductance measurements were used succesfully to map the location of subsurface contaminant migration pathways from the vicinity of a liquid hazardous waste disposal site. (Sect. 2.2.3)

- An environmental analysis of the operation of ORNL was published. The report gives a comprehensive account of discharger, past and present management policies, and an asseasment of the significance of impacts to the environment and buman health and safety. (Sect. 2.2.6)

- For the NRC, a method was developed and applied to extimate the commercial and recreational fisheries harvest rates within an $80-\mathrm{km}$ radius of nuclear power plants in the United States. Initial results indicate that previous methods may overeatimate marine recreational harvests by as much as two orders of magnitude. Since such eatimates are used to eatimate the potential effects of miajor reactor accidents, the differences are significant. (Sect. 2.2.7)

- A study of the poseible community paychological effects of the restart of Three Mile Island (TMI) Unit I indicated that the most likely effect is an increased level of community and interpersonal conflict resulting from extreme polarization over the 
Talle 1.1 icantiman

insen Other impacts litely to occur, bet at uolnown levela, include an increase in streas, a change in levels of recidential antiffection, a change in boal ecosomic conditions, and increased migration. Community proffing revenled that $30 \%$ to $50 \%$ of the population exhibits characteristics that can be anociated with fectors thought to betp cause inpacts. (Sect. 3.2.1)

\section{B. Energy and Resource Analysis}

- For AID, en ascesement of energy aptions for Liberia was completed as a collaborative effort with the Liberian government. Among the mont aignificant findings were (1) that there is sabetantial potential to dippiace imported oil by more use of domestid energy resources, notably wood and hydropower, and (2) that the country can eave an eatimated S15-20 million per year by shutting down its antiquated oil refinery and buying finished petroleum products on the ward market. (Sect. 7.2.1)

- ORNL is assisting EIA in its work to evaluate the viability of the U.S. aranium mining and milling industry. During FY 1983 a set of criteria for jedging viability was formulated, three public hearings were held, and, on the basis of comments received, a final set of criteria was announced by EIA in the Federal Register in October 1983. Additionally, research was initiated on developing analytical approaches to estimating and projecting the statc of the world uranium market and the part played by domestic producers. (Sect. 4.1.4)

- Short-term forecasts for EIA of highway gasoline and diesel fuel demand correctly predicted increased oil use in 1983, reversing an unprecedented four-year decline. If economic growth continues, gasoline consumption could grow at an average rate of 1\% through 1985. (Sect. 3.4.4)

- Research to evaluate the effectiveness of utility esergy conservation programs has revealed a subatantial consistency in outcomes for the programs audied to date, including those run by Northeast Utilities in Connecticut, Northern States Power in Minnesota, and Bonneville Power Administration in the northwest. Reaidential energy audit programs result in small but statistically significant savings of 5-6 GJ per year per household compared to similar households not receiving audits, but saving averaging four to five times larger were achieved when bow- of no-interest bons or other customer financial incentives were used. The cont-effectiveneas of these programs depends greatly on the circumstances of individual utilitiea. (Sect. 5.2.1)

- Much of the energy savings reported by states under the DOE State Energy Conservation Program has been presumed to be because of the effects of new local building codes, many of which require meeting or exceeding ASHRAE Standand 90-75. A statistical analysis of the data on the thermal efficiency of new homes built around the country, however, did net reveal a strong correlation between improving efficiency and the extablishment and implementation of the codes. (Sect. 3.1)

- The DOE Energy-Related Inventions Program was evaluated, and the conclusion was that the grants program has a succeas rate a high ws that reported for private venture capital firms. Of the 165 inventions awarded government grants between 1975 and 1982, 46 had been able to attract follow-on financing, and 35 inventions had reached the marketplace, with cumulative sales of $\$ 178$ million. (Sect. 3.2.2)

- Various methods for determining the value of fuel minerals on government lands were analyzed for the Minerals Management Service of DOI. The methods are needed to determise royalty payments to the government. Methods were recommended for coal and natural gas. (Sect. 3.3.1) 
Talle 1.1 (contione)

- A study was initiated for DOE/EIA to try to ideatify the caveres for the differeace between preconstruction cost estimates and actual costs for asclear poner plants. Analysis of the data for 51 plants indicated that the difierence has grown almoet linearly over the years and that, for the plants completed moat recently, the difference has amounted to as moch as $52000 / \mathrm{kW}(\mathrm{e})$. (Sect. 4.1.2)

- The difficulties of determining a fair price for utilities to pay cogenentors for excess power were analyzed for EIA. It was shown that setting the prics as the average cout to the utility for producing the additional amount mpplied by the coseacrator does not adequately account for riat borne by tie vtility. It is abo difisicult to fector in such iswes as time-of-day demand, scheduling, and reliability. (Sect 4.24)

- A study of the "need for power" from the now-defunct Clinch River Breeder Reactor (CRBR) was completed for DOE. The results indicated that, for the Sontheastern Electric Reliability Council (but not including Florida), committed or planned electrical generating capacity for the region would be significantly les than forecasted peak demand requirements by 1995 but that the CRBR power output of $350 \mathrm{MW}$ would be only 3-9\% of the shortfall in 1995 and 1-2\% in the year 2000 . (Sect. 4.2.1)

C. Emergency Preparedness

- New computer-assisted techniques have been developed to rapidly aseess and update eximates of the geographical distribution and number of people rexiding within a 16-km (10-mile) radius of existing and proposed nuclear power plant siter. A variety of alternative methods, including the use of Landeat (satellite) data, has been tested and evaluated. However, none have been proven to be atatiatically significant improvements over the basic computer approech that uses digital eaumeration diatrict centroid data available from the U.S. Bureau of Census and digitized exclusion zones such ds water bodies and known uninhabited zones. (Sect. 2.1.1)

- For the NRC, a atudy was completed to evaluate the interface between utilities and off-site organizations in emergency planning and response. Rexearch results suggeat that implementation of exiating regulations has led to comprehensive planning efferts and that, although interorganizational communication may not be optimal, planning and teat exercises should help ensure reasonably comprehensive response to emergencies. (Sect. 3.5.3)

- In an asalysis of human factors that may have an impact on reactor accident classification and off-site notification, it was concluded that a change in the clascification system will eliminate many of the problems in accident claseification decision making. Notification of off-site officials is not bighly susceptible to human problems, and it is not a significant factor in the clasuification decision. (Sect. 3.5.3)

- In light of experience at TMI, the requirements for robotic equipment for we by DOE in radiological emergencies were ascened. The advances in digital control and forced feedback, coupled with the development of a six-legeed, computer-controlled walker by Odetic Corporation, offer considerable promise for use of robotics in coping with harsh environments. (Sect. 3.5.2)

- Although earth-sheltered housing can provioe procection againat tornadoes, foreat fires, power outages in cold weather, and radiolozical pround contamination and can be easily upgraded to a blast shelter status in time of national emergency, such housing is unlikely to substantially penetrate the residential market without some form of subsidy. The additional cost of construction compared to that of a 
Table 1.1 (coutinned)

conventional frarne structure overrides the life cycle energy savings, and the emergency preparedness advantage of earth sheltering may not be a sufficiently attractive feature to offset the additional cost. (Sect. 3.5.1)

- For the Electric Energy Systems Division of DOE, a detailed researct: plan to assess thu effects of electromagnetir pulse from a nuciear explosion on the U.S. power system was completed. (Sect. 6.1.4.2)

- Even with the present Iran-Iraq War, there exists today an effective world oil production capacity of about 5 million tarrels per day in excess of world demand. Nevertheless, with a substantial economic recovery in the United States and dround the world, this gap could narrow substantially within three years, and the world could again enter a "band of risk" where another oil crisis could be triggered. (Sect. 7.2.2)

- An optimum oil stockpiling model was applied to various import disruption scenarios. Depending upon assumptions, the optimal public-plus-private U.S. stockpile levels ranged from about 40 to 315 million metric tons ( 300 million io 2 trillion barrels), and the total expected economic loss from disruption ranged from about $\$ 100$ billion to $\$ 400$ billion. For any given scenario, results were found to be relatively sensitive to values of short-run demind elasticity but not very sersitive to changing the speed at which the market is assumed to adjust (e.g., more rapid adjustment could result from $R \& D$ on synthetic fuels technology). (Sect. 4.2.3)

- In an analysis for EIA, fuel-switching capability in the industrial and util y sectors was estimated. It was concluded that 22,000 metric tons per day $(160,000 \mathrm{bb} / \mathrm{d})$ of oil was burned in 1982 in electricity-generating plants with dual-fuel capacity and that, in the period 1976-1979, about 61,000 metric tons per day. $(450,000 \mathrm{bbl} / \mathrm{d})$ of oil was used in large industrial boilers that can be switched from oil to other fuels. It was suggested that more recent data on the industrial sector are needed. (Sect. 7.1.2)

- For EIA, ORNL developed a variety of region-specific monthly consumption models for seven different petroleum products. These region-specific models of petroleum product consumption are needed for providing short-term piojections to support decision makers in the event of a petroleum supply disruption. In addition, data for the Turner, Mason, and Associates linear programming model of domestic petroleum refinery operations were updated, and the model was used to estimate likely regional responses of refinery output to a crude oil shortage for those same products. (Sect. 5.2.4)

\section{MODELS AND DATA SYSTEMS}

\section{A. Models}

- A computer code (MIGRAT) was developed for the NR.C to simulate the transport of moisture and multiple decaying and retarded contaminants in unsaturated porous media. The model is being used to assess the impacts of various approaches to disposal of uranium mill tailings. (Sect. 2.2.2)

- Research to evaluate atmospheric dispersion models for use in emergency situations (such as during a reactor accident) continued, with both analytical and experimental usting. Results to date show that sophisticated particle-in-cell codes produce no better results than simple puff-type codes. To determine the usefulness of candidate models in an emergency response mode, the real-time capabilities of each code are presently being studied. (Sect. 2.2.5) 
Talk 1.1 (contioned)

- A set of models was developed for EIA to forecast transportation sector fuel demand over a ten-year period as part of the EIA Intermediate Future Forecasting System. The highway model projects fuel consumptions of gasoline and diesel fuel by exch of three vehicle types (automobile, single-unit truck, and tractor-trailer truck) using four exogenous inputs: price of gasoline, price of No. 2 distillate, personal disposable income, and gross national pruciuct. (Sect. 3.4.1)

- Several ORNL energy ent-use models were upgraded during FY 1983, particularly the residential sector moiel. The improvements were funded partly by Bonneville Power Administration and included (1) incorporation of a nested logit fuel an: equipment choice approach, (2) simultaneous optimization of shell and equipment efficiency choice for each building type and up to 81 configurations of fuel and equipment type, (3) a Lagrange multiplier methodology for estimating the effect of goverament policies and conservation programs, and (4) development of fuel choice and usage econometric components fully consistent with the engineering/ technology-based simultaneous optimization and etficiency determination. (Sect. 4.2.7)

- As part of a collaboration with the Environmental Sciences Division, a model, FIRSTCUT, was developed for DOE's Biomass Energy Technology Division to analyze the economics of growing short-rotation intensive-culture woody biomass crops for fuel or chemicals. The model was used for two systems, mesquite and hybrid poplar, to show how preduct cost depends on such variables as length of cutting cycle, number of coppices, discount rate, biomass productivity, and the costs of establishment, cultural management, and harvesting. (Sect. 4.2.2)

- For AID, a macroeconomic model of the cconomy of Liberia was developed, together with complete economically estimated equations for simulating energy use by various sectors. Use of the model illustrates the sensitivity of economic growth and energy use to world market conditions for petroleum, wood producis, rubber, and iron ore. (Sect. 4.2.5)

- Under ElA sponsorship and in collaburation with the Engineerirg Technology Division, the Federal Energy Regulatory Commission (FERC) hesdwater benefits model was fully documented, evaluated, and, to some extent, improved and corrected. This is the model used by the FERC staff to compute annual gains in generated hydroelectric energy and increased dependabie capacity at power plants downstream from federai dams. Among the significant improvements were a better technique for determining and valuing dependable capacity gains and changes to make the code run more efficiently. (Sect. 4.2.6)

- For the Naval Weapons Engineering Systems Activity, a model used to predict the performance of auiomated aircrew ejection systems was documented and reformatted to run on IBM computers and was evaluated against theoretical considerations and experimental observations. (Sect. 5.2.6)

\section{B. Data Systems}

- ORNL is designing a system that will allow traffic engineers and city planners to more easily and effectively use the extensive traffic control computer models developed by the Federal Highway Administration of the DOT. The approach is to provide, in the field, microcomputer interfaces to the central DOT mainframe computers on which the models are run. The trick to solving the interfacing problem is the development of a flexible integrated traffic data model by which the user can 
Talle 1.1 (contined)

be cued by the microcomputer in preparing data input to any of the msiels and can receive the output back in a convenient and usable ferm. (Sect. 3.4.2)

- Also for the Federal Highway Administration, ORNL is testing 15 automobiles to develop data-based simulators of fuel consumption and emissions. These 15 vehicles (including diesels) are expected to represent about 60\% of the 1979-1985 passenger vehicle population, and the simulators are designed to be applicable to traffic models of the Federal Higiway Administration. By the end of FY 1983, ten vehicles had been tested, and the fuel simulator resulis agreed well with the EPA highway fael use cotimates for the models compared. (Sect. 3.4.3)

- During FY 1983, ORNL, in collaboration with TVA, Lockheed Corporation, and East Tennessec State University, completed a national inventory of abandoned mine land problems with emphasis on those problems impacting public bealth, safety, and gerseral welfare. The inventory, which includes data concerning 6,137 Problem Areas in 35 states and land of 4 Indian tribes, is a nationally standardized dat: oase in which the same rules of classification and prioritization of problems were used for the data from each state and tribe. The results indicate that there are likely to be sufficient funds from taxing current mining operations to correct the health, safety, and general welfare problems but probably not enough to correct all environmental problems not directly affecting public health, safety, or general welfare. (Sect. 2.2.4)

- For EIA, an analysis of information requirements regarding alternate or renewable fuels, including solar, biomass, wind, and geothermal, was completed using a new approach. Each item of information needed by some user was ranked according to a nonmonetary measure of benefit divided by cost. The benefit index was derived from the estimated contribution of the information items to national goals, and the cost index was estimated in terms cí accuracy required, size of respondent population, and degree of respondent burden. The requirements review resulted in a number of specific recommendations to EIA for infonnation collection changes and additions. (Sect. 5.2.2)

- A requirements review of information about the nuciear industry was also performed for ElA. It was found that users needed more and better information on power plant construction; uranium exploration, supply, and reserves; and spent fuel storage. Adequate information is available on operating power plants, and information on uranium conversion and enrichment, fuel fabrication, and research reactors was either available or could be considered "nct required." (Sect. 5.2.3)

- For the Army Materiel Development and Readiness Command, a data system is being developed to implement the concept of major item system mapping which will relate all hardware components to the major weapon, support, and ammunition systems of which they are a part. The hierarchical data base will be used to produce computer-displayable maps for 1500 to 2500 major item systems containing some 10,000 components. (Sect. 5.2.5)

- ORNL has proposed a fault-tolerant, parallel-processor, modularly expandable system for the Army Logistics Control Activity to update its present data base management system, which is used to keep track of material requisitions throughout the Army. The proposed system should accommodate, at reasonable cost, substantial increases in the data base and the rate at which it can be updated and manipulated. ORNL may be asked to develop and test a prototype to demonstrate that the proposed sysiem is a good solution to the upgrading problem. (Sect. 5.2.7) 


\section{TECHNOLOGY DEVELOPMENT}

\section{A. Heat Pumps}

- Three subcontractors (Carrier Corporation, the Trane Company, and Phillips Engineering Company) have completed exgincering analyses which suggest that advanced absorption leat pumps using ratural gas as a fuei may be able to achieve heating coefficents of performance abnve 2.0 and cooling coefficients of performance ranging from 1.4 to 1.8. If this jerformance can be achieved with systems that are economic, the development will represent a significant breakthrough. (Sect. 6.2.1.1)

- The ORNL beat pump model was used to demonstrate optimal design for modulated air-to-air heat pumps. For a home in Nashville, Tennessee, the results indicate annual energy savings of about $26 \%$ over those of an optimized single-speed machine as a result of the combined reduction of cycling lossts, frosting losses, heat exchanget uninading, and resistance heating. Cycling losses alone (amounting to about 11\% of energy use) can be reduced substantially and probably more cheaply without modulation (e.g., by use of solenoid valves). (Sect. 6.2.1.2)

- Research on ground-coupled heat pump systems is under way for DOE in colloboration with Brookhaven National Laboratory and Niagara-Mohawk Power Corporation. Heat transfer models to simulate the effects of moisture migration and phase change on the heat exchanger/soil interaction are being developed and tested by field and laboratory experiments. Seasonal heating factors of about 2.5 were obtained, but cosling season factors varied from 1.3 in clay soils to 1.9 in sandy soils. (Sect. 6.2.1.3)

- Analytical studies of an externally powered (e.g., electrically driven) Stirling heat pump suggest that such a device could achieve interesting coefficients of performance, especially if an isothermal condition can be achieved. The advantage over conventional Rankine cycle air-to-air heat pumps would be that the capacity and coefficient of performance for the Stirling cycle do not drop off rapidly with decreasing outdoor temperatures. The Stirling cycle might be very useful for cold clinnates and has the added environmental advantage of not using fluorochlorocarbons. (Sect. 6.2.1.4)

- The prototype of an $\mathrm{LiBi}-\mathrm{H}_{2} \mathrm{O}$ absorption heat pump for using low-temperature $\left(60^{\circ} \mathrm{C}\right)$ wasce heat to produce process steam temperatures for industrial applications was successfully demonstrated. Single-stage boosts of $22^{\circ} \mathrm{C}$ (with $15^{\circ} \mathrm{C}$ cooling water) were achieved, in good agreement with analytical extimates, and preliminary projections of the er vnomics of a two-stage machine to produce process steam temperatures look pr mising. The prototype fiatures a unique adiabatic absorption stage to enhance the temperature boost. The teat results indicate that the kinetics of the absorption process in the adiabatic step are much more rapid than had been expected. (Sect. 6.2.2.2)

- A theory of simultaneous mass and heat transfer for absorption of a gas or vapor into turbulent liquid films was developed for the cases of an adiabatic and an isothermal wall. The theory should be useful in the design of absorption heat pumps. (Sect. 6.2.2.1)

- For st.e Building Energy Research Division of DOE, the cost-effectiveness of various retrofit measures was investigated. One concept studied was an add-on heat pump 
Table 1.1 (contined)

that is applicable to beildings with existing forced-air systems and fossil-firud furnaces. The idea is to take advantage of the high efficiency of the electric heat pump during periods of moderate weather. It was found that the heat pump mikes the most sense where the furnace is not very efficient, electricity prices ar: less than about $6 \notin / \mathrm{kWh}$, and a central air conditioner needs to be replaced. (Sect. 6.2.5.1)

B. Buildings

- The effect of uninsulated thermal mass in the cxternal walls of buildings was investigated in two extensive sets of experiments, one at the National Bureau of Standards, Gaithersburg, Maryland, and the other at the New Mexico Energy Research and Development Institute near Santa Fe, New Mexico. In general, tbe results were predictable in that wall thermal mass is effective for improving energy efficiency only when diumal swings in ambient temperatures provide periocis when ambient temperature is alternately above and below inside temperatures. The results provide the basis for generalization for any part of the country. (Sect. 6.2.4.1)

- Data ior a complete heating and cooling season wert obtained at the earth-sheltered, passively heated uffice/dormitory building of the Joint Institute for Heavy Ion Research at ORNL. The results give detailed information about the magnitude and nature of heat losses a.nd gains for brth summer and winter; for example, 45\% of the heat luss during winter is due to infiltration and maintaining a 0.5 -air-change-perhour ventilation rate, while another $25 \%$ is lost through the windows at night. By reducing this window loss with reflective insulacing blinds (just installed), it should be possible to cut heat pump requirements in half and raise the percent of solar heating in the building from 55\% to 75\%. (Sect. 6.2.4.3)

- A roofing thermal research apparatus capable of testing four $1.2-\mathrm{m} \times 2.4-\mathrm{m}$ roof panels was designed and constructed. The apparatus will be used to evaluate models of heat transfer and investigate the effects of moisture. (Sect. 6.2.4.2)

- A detailed analysis was made of the comparative econonics of the following cptions: (1) renovating the antiquated steam district heating system at ORNL or (2) replacing it with a new hot water system using European technology. The higher capital cost of the hot water system had a simple payback period of about five to six years, resulting from estimated lower fuel and operating costs compared to those of the steam system. (Sect. 6.2.6.2)

\section{Power Systems}

- The Athens, Tennessee, distribution automation and control experiment being conducted for the Electric Energy Systerns Division of DOE in collaboration with TVA, the Athens Utility Board, and the Tennessee Valley Public Power Association took a giant step forward with the seiection of a contractor, Brown Boveri Control Sysi .ns, Inc., to provide the communication and control system. During FY 1983, detailed design of the system was largely completed, and hardware and software production was well under way. The system will be capatle of switching substation and feeder devices, switching customer loads, and monitoring the status of power system values as well as customer loads. It will employ distributed intelligence features and should aid operators during both normal and emergency conditions, help reduce peak loads, provide better interface between the bulk suppliers and the end users, and help accommodate dispersed power generation and/or storage. (Sect. 6.2.3.1) 
- In three subcontracted studies, the power system and safety problems associated with dispersed generating sources (c.g., photovoltaics or wind machines) were investigated. For a low penetration of these sources, only minor changes in safety practices and protection hardware will be required, but with 1 istantial penetration the complexity of controlling, protecting, and maintaining the distribution system wil: increase to the extent that distribution automation may be required. (Sect. 6.2.3.2)

- A study of small corgeneration systems [ $<500 \mathrm{kW(e)]} \mathrm{for} \mathrm{applications} \mathrm{to} \mathrm{buildires} \mathrm{on}$ Navy bases, such as hospitals and unaccompanied enlisted personnel housing, indicated that such systems could indeed be economically attractive with simple. payback periods as low as four to five years, depending on the particular application and the cost of purchased electricity. (Sect. 6.2.6.1)

\subsection{RESEARCH UTILIZATION}

The principal users of the results of Energy Division research are, of course, the sponsors of the research. But the results often have broader usefulness, and it is an important responsibility of a national laboratory to encourage utilization by others. Specifically, this utilization effort may involve technology transfer to encourage use ty the private sector, technical assistance to state and locai governments (and occasionally to the governments of developing nations), and various other avenues of technical communication and information dissemination.

During FY 1983 the staff worked on or completed a number of state-of-the-art reviews designed to give users practical "how to" information. These included

1. Guidance for the Disposal of Uranium Mill Tailings: Long-Term Stabilization of Earthen Cover Materials. ${ }^{10}$

2. Design Considerations for Long-Term Stabilization of Uranium Mill Tailings Impoundments."

3. A waste treatment handbook for low-level radioactive wastes (in progress).

4. A shallow-land burial handbook for low-level radioactive wastes (in progress).

5. A review of corrective measures to stabilize subsidence in shallow-land burial trenches (in progress).

6. Revision of radiological defense handbooks for FEMA. ${ }^{12,13}$

7. Eight case studies of various state and community energy conservation programs. ${ }^{14,15}$

8. Residential Conservation Service Model Audit Manual. ${ }^{16}$

Assistance to state and local governments took a variety of forms. A mammoth project to develop a computerized inventory of abandoned coal mine land problems was completed for DOl's Office of Surface Mining with the assistance of states and Indian tribes." This inventory should be useful to the states in prioritizing work on abandoned mine problems. Workshops were held in Salt Lake City, Utah, Providence, Rhode Island, and Philadelphia, Pennsylvania, to discuss the problems of, and techniques for, evaluating state and community energy conservation programs. In addition, technical assistance was provided to states and utilities in connection with the implementation of the Residential Conservation Service and the Commercial and Apartment Conservation Service programs of DOE. For DOT, a microcomputer-based system is being developed to provide 
community traffic engineers with user-friendly access to DOT traffic models (Sect. 3.4.2). The ORNL Residential Sector Erergy Use Model was transferred to Iowa State University for wost for the Iowa Commerce Commission. A briefing on the ORNL Integrated State Level Forecasting Model was presented at a conference on electric utility load forecasting sponeored by the Maryland Power Plant Siting Prigram.

The staff was also involved in projects to lelp developing nations with their energy problems. These projects were sponsored by AID. The principal effort was an assesesment done in collaboration with ahe Government of Liberia to develop an overall energy sirategy for the country. ${ }^{18}$ The results of this analysis are being used by the World Bank and Arthur D. Little, Inc., for AID. Also, assistance was provided to Tunisia in modeling the use of fuels by highway vehicles.

Technology transfer to the private sector continued primarily in the areas of efficiency improvement and power systems research. This research continues to invoive equipment manufactirers through subcontracting. Approximately $\mathbf{4 0}$ subcontracts with industrial companies were active in FY 1983. One of these companses, Wextinghouse, is Jeveloping a high-eficiency airto-air heat pump incorporating a unique two-speed compressor. A special effort was made to keep the Electric Power Research Institute (EPRI) informed about the progress of the Westinghouse research as it occurred. In general, there are periodic visits and exchanges of information with both the Gas Research Institute and EPRI. Also, the staff visited a number of large and small heat pump nuanufacturing firms to inform them of the research in progress. Many representatives from industrial firms visited the Laboratory to discuss areas of mutual interest. In addition, the ORNL hest pump model continuss to be requested by a growing number of manufacturing firms.

Collaborative research either was or is in progress with a number of utilities. Examples include (1) the Niagara-Mohawk Power Company on ground-coupled heat pumps; (2) the Athens Utility Board of Athens, Tennessee, and TVA on electric distribution system automation and control; and (3) the Bonneville Power Administration, Northeast Utilities of Connecticut, and Northern States Power of Minnesota on evaluating the effectiveness of utility energy conservation programs.

ORNL staff helped with planning of the recently established Building Thermal Envelope Coordinating Council, the purpose of which is to exchange information on building research between multiple public and private organizations. This activity is carried out through research coordinatina committees on such areas as insulation, indoor air quality, thermal mass, roofing, and diagnostics. Also, summer workshops for university faculty were held again in 1983-one for architects and the other for engineers. The ongoing program is to inform faculty participants of the latest developments coming from DOE-sponsored researct: on tuildings.

Some activities involved transfer of research results to various government agencies and organizations that did not sponsor the original work. A two-week workshop was conducted for geologists from the Bureau of Land Management on methods for extimatiog the probability of fuel and other mineral resources on unexplored land. The ORNL Building Innovations Economic Analysis Model' ${ }^{19}$ was transferred to Pacific Northwest Laboratory (PNL) and to EIA. It is being used by PNL in cooperation with the American Society of Heating, Refrigerating, and Air Conditioning Engineers (ASHRAE) to suggeat voluntary building energy performance standards for i. unresidential buildings. The staff also contributed to a report by the National Acedemy of Sciences Committee on Behavioral and Social Aspects of Energy Consumption and Production. ${ }^{20}$

Technical communications and information discemination included interaction with peen, sponeors, and the interested public and the recording of results of the work (Chap. 8). During FY 1983, the staff published 54 articles in scientific or technical journals, and 30 others were accepted 
for publication. In addition, 80 ORNL reports, 2 books, and 17 book chapters were published; 26 fapers were printed in the proceodings of technical meetings; and 6 covironmental impact itatements, assessments, or appraisals were issued. Additionally, the Division held or organized 17 workshops anci symposia and hosted many visitors from universities, government organizations, industry, and sther research institutions.

\subsection{REFERENCES}

1. S. E Beall et al, Energy Division Anual Progress Report for Period Ending December 31. 1974, ORNL-5030, Odk Ridge National Laboratory, April 1975.

2 W. Fulkersor et al, Energy Division Anumal Progress Report for Period Ending December 31 . 1975, ORNL-5124, Ozk Ridse National Laboratory, April 1976.

3. W. Fulterson a al, Energy Division Amwal Progress Repon for Period Endine September 30.1976. ORNL-5250, Oak Ridge National Laboratory, April 1977.

4. W. Fulkerson a al. Emergy Division Anwal Progress Repon for Period Endins Seprember 30.1977. ORNL-5364, Oal: Ridge National Laboratory, April 1978.

5. W. Fulkersoa a al, Energy Division Anual Progress Report for Period Ending September 30, 1978, ORNL-5513, Oak Ridge National Laboratory. March 1979.

6. W. Fulkerson et al., Energy Division Annual Progress Report for Period Ending September 20.1979. ORNL-5638, Oak Ridge National Laboratory, June 1980.

7. W. Fulkerson a al., Energy Division Anmual Progress Report for Period Ending September 30.1980, ORNL-5740, Oak Ridge National Laboratory, November 1981.

8. W. Fulkerson at al, Energy Division Anwual Progtess Report for Period Ending September 30.1981. ORNL-5872, Oak Ridge National Laboratory, May 1982

9. W. Fulkerson a al., Energy Division Annual Progress Repon for Period Ending Sepeember 30. 1982. ORNL-5947, Oak Ridge National Labozatory, June 1983.

10. L. D. Voorhees, M. J. Sale, J. W. Webb, and P. J. Mulholland, Guidance for Dispasal of Uranium Mill Tailings: Long-Term Stabilization of Earthen Cover Materials, ORNL/TM-8685, NUREG/CR-3199. Oak Ridge National Iaboratory, June 1983.

11. J. D. Nelson, R. L. Volpe, R. E Wardwell, S. A. Schumm, and W. P. Staub, Design Considerotion! for Long-Term Slabilization of Uranium Mill Tailings Impoundmems. ORNL-5979, NUREG/CR-3397, Oak Ridge National Laboratory, September 1983.

12. Federal Emergency Management Agency. Guide for the Design and Development of a Local Radiological Defense Support System, Civil Preparednets Guide Series CPG 1-30, June 1981.

13. Defense Civil Preparedness Agency, U.S. Department of Defense, Radiolocical Defense Preparedness, Civil Preparednews Guide Series CPG 2-6.1, April 1978.

14. M. Schweitzer and S. A. Carnes, Local Govemment Programs 10 Save Enero: Case Studies of Four Selected Commuxities, ORNL-5982, Oak Ridge National Laboratory, September 1983.

15. E. Peelle, R. B. Braid, D. W. Jones, and J. H. Reed, Reaching People with Enerey Conservation Information: Four Statewide Residential Case Studles. ORNL-5984, Onk Ridge National Laboratory, September 1983.

16. M. A. Karnitz, T. K. Stovall and H. A. McLain, Residential Conservarion Sentce Model Audit Manual, OR'JL/CON-103, Oak Ridge National Laboratory, October 1983.

17. R. B. Honea et al., A Notional Inventory of Abondoned Mine Land Problems: An Emphasis on Healih, Safely, and General Welfare Impacts. OSM/TR-4/83, prepared by Oak Ridge National Laboratory and the Tennesuce Valley Authority for the U.S. Department of the Interior, Orfice of Surface Mining. Auzust 1983. 
18. W. F. Barron, M.-H. Neufville, a al. An Assessment of Energy Options for Liberia, ORNL-5989, Oak Ridge National Laboratory, November 1983.

19. D. M. Flanagan, D. M. Hamblin, and B. Thomas, Jr., Completion of a Public Domain Life-Crele Cast Code: Documentation and Validation of the Building Innovations Economic Amalysis (BIEA) Cade. ORNL/TM-8962, Oak Ridge National Laboratory, Oct. 10, 1983.

20. Energy !/se: The Human Dimention Report of the Committee on Behavional and Social Aspects of Energy Consumption and Production, National Academy of Sciences/National Research Council, W. H. Freeman, San Francisco, 1984. 


\title{
2. Environmental Impact Section
}

\author{
H. E. Zittel
}

\subsection{INTRODUCTION}

The work carried out in the Environmental Impact Section during FY 1983 demonstrates an ever-increasing trend toward applied research as compared to past years, when our major efforts were focused on preparation of documents to meet the requirements of the National Environmental Policy Act (NEPA). The expertise developed in thr, section in multidisciplinary areas as the result of such NEPA activities is becoming increasingly recognized on both a local and national scale. The U.S. Nuclear Regulatory Commission (NRC) and the U.S. Department of Energy (DOE) continue to be our major sponsors in both the NEPA and applied research areas. In the following sections of the introduction, the work carried out for the NRC is summarized briefly, as are the activities performed for the DOE in our nuclear, fossil, and conservation and renewables programs. In addition, the research activities of the Integrated Assessment and Applied Physical Sciences groups are described. The remainder of the chapter describes selected technical highlights.

\subsubsection{NRC Nuclear Program}

$$
\text { M. J. Kelly" }
$$

$\begin{array}{lllll}\text { J. S. Baldwin } & \text { G.S. Hill } & \text { R. B. McLean } & \text { R. M. Rush } & \text { J. W. Van Dyke } \\ \text { P. R. Coleman } & \text { N. E. Hinkle } & \text { P. J. Mulholland' } & \text { M. J. Sale } & \text { L. D. Vorhees } \\ \text { R. C. Durfee } & \text { C. R. Kerley } & \text { F. G. Pin } & \text { W. P. Staub } & \text { J. W. Webb }\end{array}$

The NRC Nuclear Program work continued at an overall steady level. The depression in the uranium mining and milling industry resulted in no new applications to the NRC (Office of Nuclear Material Safety and Safeguards) requiring NEPA support for mills and mines, and none are expected in the near term. We did complete, however, one final environmental statement (FES) on the Teton Uranium In Situ Leach Project in FY 1983. Relicensing activity (every five years for active facilities) should supply a steady, low level of environmental assessment work in the future.

\footnotetext{
-Program Manages.

'Computer Sciences Division.

'Health and Safety Research Division.

Environmental Sciences Division.
} 
During the past year, we completed three enviroamental impact appraisats (EIAs) on fued fabrication facilities.

The NRC move to disperse work to regional offoes resulted in the separation of our uranium milling and mining assignments into uranium resources licensing and a generic-problems area that includes low-tevel waste in addition to mill wastes. The latter area may provide continued opportunities to develop solutions to, or at least perspective on, seneric problems affecting groups other than NRC. Examples of this type of work during the past year inclode studies in Guidance for Disposal of Uranium Mill Tailings: Long-Term Stabilization of Earthen Cover Materials' and Design Considerations for Long-Term Stabilization of Uradium Mill Tailings Impoundments.

New studies still in progress include development of the computer code MIGRAT (Sect. 222), which quantifies the migration of moisture and multiple decaying and retanded contaminants in the unsaturated zone. The code has been used in both generic and site-specific atudies to ascess the impacts of open-pit disposal of uranium mill tailings. The studies have resulted in the identification of the major pathways for groundwater contamination through unsaturated zones and in recommendations to improve the design of subgrade dipposal areas.

In addition, our support work for the NP.C Office of Nuclear Reactor Regulation continued. One project was to develop population distribution plots and sector estimates for a 16-km (10-mile) radius around existing reactor sites from 1980 census data extrapolated to 1982 . The plots also show coastlines, water bodies, and other areas unlikely to contain permanent residents. The se plots are used for emergency planning. Plotting for approximately $\mathbf{3 0}$ sites remains to be completed. Alece, two remote access programs have been developed so that NRC can access the Oak Ridge National Laboratory (ORNL) computer to obtain the population distribution around any point in the coterminous United States to assist other agencies in case of major accidents. A recond project concerns fisheries harveat estimates around reactor sites (see Sect. 2.27). This effort has become generic and will cover large rivers, small rivers, reservoirs, the Great Lakes, and estuarine systems.

\subsubsection{DOE Neclear Programs}
J. B. Cannon
W. Davis ${ }^{\dagger}$
G. S. Hillt
J. R. McNally'
R. T. Santoros
I. S. Watson'
C. E. Easterly ${ }^{t}$
R. H. Ketelle
F. G. Pin
J. B. Talbot
F. W. Witten'
H. E. Goeller ${ }^{\dagger}$
D. W. Lee
R. D. Roop
R. E. Thoma

Our DOE Nuclear Program is rapidly becoming cae of our more exciting and progreasive programs. It is in this program that the section has become deeply involved in applied research related to low-level radioactive waste disposal at DOE facilities, including our own. In addition, work on magnetic fusion energy has continued.

In the fusion area, we continued to provide technical assistance to the DOE Office of Fusion Energy in developing a generic environmental impact statement (GEIS) for the national magnetic

\footnotetext{
'Propram Manager.

'Chemical Technolozy Division.

${ }^{t}$ Heateh and Safety Research Division.

'Fusion Energy Division.

'Metals and Ceramics Division.
} 
fuica program. A major deliverables a tectunical report on which she caviroameatal statemeat will be based, was completed and issued as a DOE Headquarters report. ${ }^{3}$ The preliminary draft of the GEIS received a fanorable uxchnical revien from a sebet DOE review pand. It is anticipated that the draft environmental stat:ment will be irowed in FY 1984.

In the bow-kevel waste area, several major tasts were undertaken: (1) the writing of a wate treatmeat handbook, (2) the writing of a shallow-hand barial hadbook, (3) a review of corrective measures to stabilize subaidence in shallow-land burial treacheas and (4) a comprebeavive field

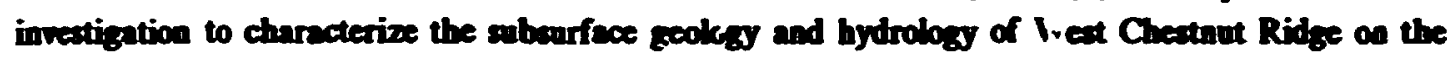
Oak Ridge Reservation. The low-level waste tentmeat madbook will provide geserators of lowlend wate with information on the options available for waste treatmeat prior to dipposal. The shallow-hand burial handbook will provide technical information for intereded individuals on the requirements, ectivitics, and commitmeats incumbeat to developmeat and operation of new shallow-land berial facilities for disposal of bow-level wate. The hapdbools are being doveloped for the DOE Low-Leved Radionctive Waste Management Program and will be ined a DOE reports in FY 1984.

In the seview of corrective measures to stabilize subsidence in shallon waste trenches, we considered roller compaction, grouting, exploxives, surcharging, falling mase, pile driving, in situ incineration, and scclerated decompocition." The falling mass technigue was found to be the most useful single technique and the ose that would yield the greated payofif from future development and field demonstration.

The site charecterization atudy for Weat Chestnut Ridge is aimod at determining the suitability of the area for diupoal d f low-level waste. The field atudy will provide data necescary for a doce-to-man pathways analysis. The study, Use of DOE Site Selection Criteria for Screening Low-Level Waste Dispasal Sites on the Oak Ridge Reservations has already proven to be of great value in this activity (see Sect. 2.21). In other atudies, members of the Applied Physical Sciences Group have used electromagnetic earth conductivity measuring equipment to map contaminant plumes at hazardous waste dispocal sites and to locate water-filled solution channels in terat carbonate terrain. The method is rapid and is vety useful as reconasiasance technique for identifying contarinant migration pathways from wase dispoeal sites (Sect. 22.3).

\subsubsection{Fossil Eaery and Comervation and Rewewalles Programs}
C. R. Boston
J. W. Boyle
F. C. Kornegay
A. W. Reed
G. K. Eddlemon ${ }^{\dagger}$
R. C. Martin
J. W. Webb'
D. B. Hunsaker

The foasil energy and conservation and renewables programs continue at an even pace. One effort of special note was the issuance of the ORNL Environusental Analysis Report (Sect. 2.2.6).

\footnotetext{
-Program Maneger.

'Enviroamental Sciences Division.
} 
The Fousil Energy Program provides DOE and the U.S. Department of Defense (DOD) with environmental assessments and technical support during the development of advanced fossil fuel facilities. Wort during the past year was focused on (1) support to DOE in reviewing environmental monitoring plans for U.S. Synthetic Fuets Corporation (SFC) projects; (2) direct environmental support to SFC in developing its comprehensive stratezy; (3) environmental, safety, and health support to the Fossil Energy Technology Centers; and (4) wastewater treatmeat studies in support of the SRC-I (solvent refined coal) coil liquefaction project.

In addition to the above work, ORNL carried out the following tasks: (1) continued for DOE/Foasil Eneryy (DOE/FE) a triweekly regulatory and legislative update that provides a concise overview of current chapizes in environmental regulation; (2) provided support to the Y-12 Phant at Oak Ridge in asseasing environmental complianse of the steam plant facilities; and (3) continued support to the DOE/Economic Regulatory Adrninistration on the Arthur Kill and Ravenswood eavironmental impact statements (EISs) for the mandated conversion of power plants from oil to coal.

As indicated, the Environmental Impact Section provided support to DOE/FE in the assescoment of environmental issues related to synthetic fuel production as part of the ORNL Fossil Energy Technology Program. The support was focused on two areas: (1) reviewing eavironmental monitoring plans (EMPs) for synthetic fuel projects secking financial assistance from the SFC and (2) participating in a systems analysis approach to analyzing available data on the environmental impacts of direct coal liquefaction.

Section 131(e) of the Energy Security Act designates DOE as a consulting agency with responsibility to assist synthetic fuel project sponsors in the development of EMPs for proposed synfuel projects. ORNL provides support to DOE/FE by conducting multidisciplinary reviews of EMPs in various stages of development. These reviews focus on the technical adequacy, content, and scope of the EMPs, with respect to Final EMP Guidelines published by the SFC. ORNL comments are used by DOE/FE in preparing DOE's official comments to prospective sponsors and to the SFC.

The Environmental Impact Section staff was responsible for the reviews in the areas of groundwater, surface water, and air quality and for managing the reviev effort. Approximately $\mathbf{3 0}$ EMP outlines covering four different resources were reviewed in FY 1983.

Another task was focused on analyzing available data related to the environmental impacts of direct coal liquefaction. The purpose of the task was to identify the lessons learned from work conducted to date and to identify future research needed to address remaining concerns. Staff members examined source monitoring for pxrmit compliznce and ambient monitoring programs relevant to surface water and air quality for the Ft. Lewis, H-Coal, Exxon Donor Solvent, and SRC-I projects. A report discussing the findings is to be delivered to Fassil Energy Technology Environmental Program management in FY 1984.

The Environmental Impact Section has been responsible for preparing EIS3 and EIAs for virtually all DOE geothermal research, development, demonstration, and loan guaranty projects and for designated solar and conservation projects. Work in these areas has continued at a fairly low level, as indicated in Table 2.1. 


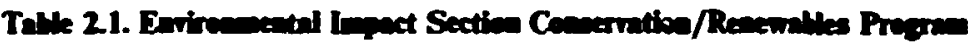

\begin{tabular}{|c|c|}
\hline Project & Sponsor \\
\hline \multicolumn{2}{|l|}{ - Conservation } \\
\hline $\begin{array}{l}\text { - Commercial and Apartment Conservation } \\
\text { S.:vice Program Final EIS Supplement, } \\
1983\end{array}$ & $\begin{array}{l}\text { DOE/Conservativa and } \\
\text { Renewable Energy (HQ) }\end{array}$ \\
\hline \multicolumn{2}{|l|}{ - Renewables } \\
\hline \multicolumn{2}{|l|}{ Geothermal } \\
\hline $\begin{array}{l}\text { - Retrospective Examination of Geothermal } \\
\text { Environmental Assessments, } 1983\end{array}$ & $\begin{array}{l}\text { DOE/Coothermal and Hydro- } \\
\text { power Technology (HQ) }\end{array}$ \\
\hline $\begin{array}{l}\text { - Evaluation of NEPA-Based Environmental } \\
\text { Commitments at Four Geopressure Design } \\
\text { Wells (ORNL/TM-8657), 19:3 }\end{array}$ & $\begin{array}{l}\text { DOE/Geothermal and Hydro- } \\
\text { power Technolozy (HQ) }\end{array}$ \\
\hline $\begin{array}{l}\text { - CU-1 Venture, Geothermal Loan Guaranty, } \\
\text { Draft Environmeatal Ascessment, } 1983\end{array}$ & $\begin{array}{l}\text { DOE/San Francisco } \\
\text { Operations Ofijice (SAN) }\end{array}$ \\
\hline \multicolumn{2}{|l|}{ Biomass } \\
\hline $\begin{array}{l}\text { - Teanol, Incorporated, Loan Guarantee } \\
\text { Application, Environmental Ascessment, } \\
\text { Marion County, Tennesece, December } 1982\end{array}$ & $\begin{array}{l}\text { DOE/Offire of Aloohol } \\
\text { Fuels }\end{array}$ \\
\hline $\begin{array}{l}\text { - New England Ethariol, Incorporated. } \\
\text { Loan Guaraatee Application, Environ- } \\
\text { mental Assessment, Androscoggin County, } \\
\text { Maine, September, } 1983\end{array}$ & $\begin{array}{l}\text { DOE/Ofitice of Alcohol } \\
\text { Fuels }\end{array}$ \\
\hline
\end{tabular}

\subsubsection{Integrated Assessments Group}

R. B. Honea
R. C. Durfee
E. L. Hillsmant
D. P. Vogt
R. G. Edwards ${ }^{\dagger}$
R. M. Rush
D. L. Wilson ${ }^{\dagger}$

The Integrated Assessments Group has been active in a number of areas. The group operates in more of a matrix sense than perhaps any other group in our division, and much of the work is reported elsewhere (see Sect. 4.1.2). A major project, the National Inventory of Abandoned Mine Land Problems, was completed during the past year (see Sect. 2.2.4). Members of this group have also been actively involved in a number of projects such as the demographic work carried out for the NRC.

\footnotetext{
'Group Leader.

Computer Sciences Division.

'Dual capacity.
} 


\subsubsection{Applied Physical Sciences Grom}
A. J. Witten"
J. S. Baldwin
F. C. Kornegay ${ }^{\dagger}$
R. D. Roop
C. C. Gilmore
D. W. Lee
R. D. Sharp ${ }^{\ddagger}$
D. B. Hunsaker
E. C. Longt
W. P. Staub
R. H. Ketelle
F. G. Pin
S. S. Stevens

The Applied Physical Sciences Group contains the nucleus of the section's disciplinary expertise; therefore, its members have been involved in all the programs mentioned previously. The group has also carried out projects in which the project management resided within the group. The work on the Susitna EIS, headed by F. C. Kornegay, is one such example, as is the atmospheric dispersion model work (see Sect. 2.2.5).

ORNL, in conjunction with Argonne National Laboratory, is preparing an EIS for the U.S. Federal Energy Regulatory Commission (FERC) on the proposed Susitna Hydroelectric Project. The proposed two-dan. project, to impound the Susitna River $\sim 180$ miles north of Anchorage, Alaska, would supply hydroclectric power to the south-central portion of Alaska, between Fairbanks and Anchorage. The upstream dam, Watana, is designed to be an earth-filled structure $270 \mathrm{~m}$ $(885 \mathrm{ft})$ high and $1250 \mathrm{~m}(4100 \mathrm{ft})$ long, with an installed capacity of $1020 \mathrm{MV}:$. The downstream dam, Devil Canyon, would be a concrete arch dam $197 \mathrm{~m}(645 \mathrm{ft}$ ) high and $457 \mathrm{~m}$ (1500 ft) long, with an installed capacity of $600 \mathrm{MW}$.

ORNL's personnel are analyzing the impacts on the hydrology and fisheries of the project area and downstre:m, while Argonne personnel are analyzing other areas of concern. The main body of the EIS will compare the impacts of the pruposed project with the impacts associated with other methods of meeting the area's electrical needs, such as other operational scenarios, other Susitna dam sites, alternative hydro sites in the region, and alternative methods for generating electricity, including coal, oil, and natural gas. The impacts of each method for producing the forecast electrical needs of the region will be presented in the EIS and will be considered in the decision to grant or deny the license, as well as forming the basis for any environmental conditions or required mitigation measures that may be attached to the license.

Several other projects were initiated in the past year, probably the most important of which is a study on sonic tomography for use in site characterization. Geophysical diffraction tomography is a new technique that shows promise as a tool for quantitative subsurface imaging. The approach being studied at ORNL is based on the Filtered Backpropagation Algorithm, which is a mathematical extension of the reconstruction software used in cosiventional X-ray CAT scanners. The difference between this method and existing methods is that the new algorithm vigorously accounts for diffraction effects through an exact inversion of the wave equation. This refinement is important in that it admits the use of acoustic and long-wavelength electromagnetic waves, allowing tomography to be taken from the laboratory to the field.

The fieid configuration under consideration at ORNL is a linear array of acoustic transmitters along the ground surface and a linear array of receivers in an adjacent borehole. Our work to date

\footnotetext{
Group Leader.

'Metworology Subgroup Leader.

Computer Sciences Division.
} 
has involved a laboratory effort to verify the algorithm and a limited field program to study acoustic wave attenuation in soils in order to demonstrate the resolution achievable in the field. Both of these tests were successful, suggesting that geophysical diffraction tomography is a viable tool for high-resolution subsurface characterization. Figure 2.1 is a simulated reconstruction using synthetic data to demonstrate the nature of the image provided by the new technique. This figure clearly shows the soil-aquifer interface along with a number of buried drums.

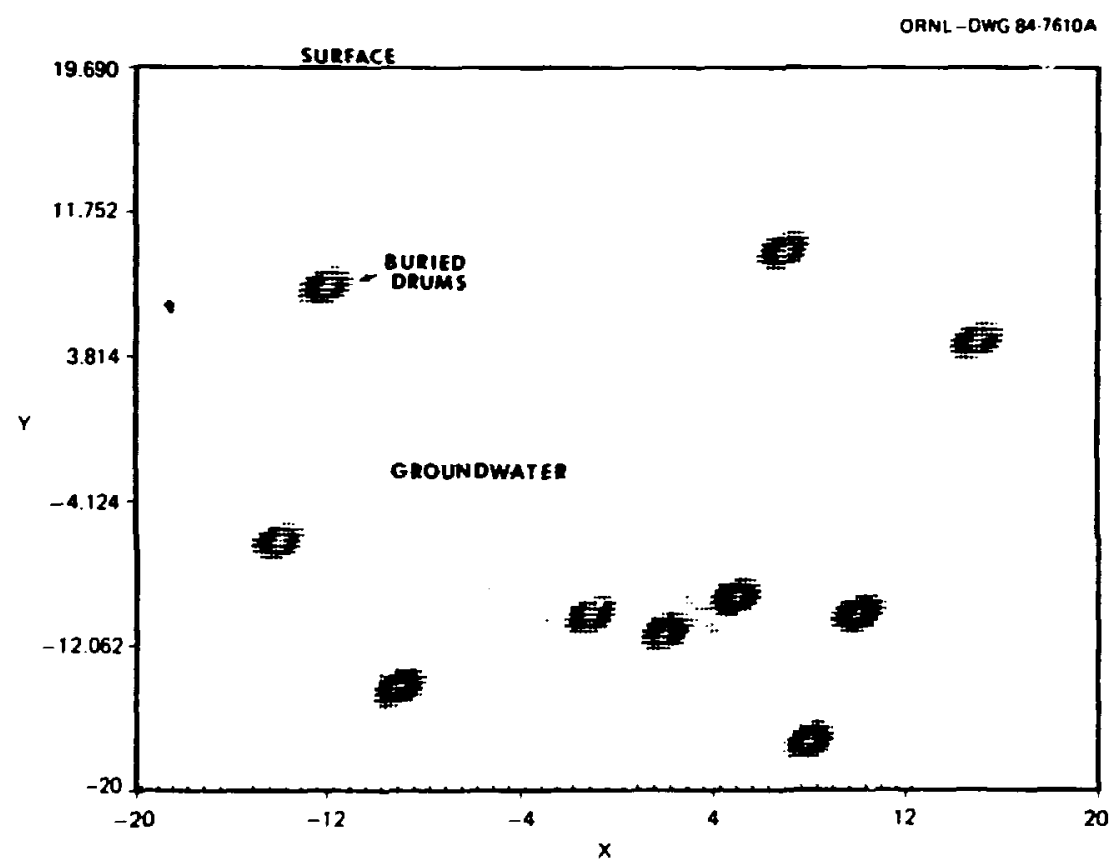

Fig. 2.1. Competer-generated reconatruction (wise synthetic data) of a rertical

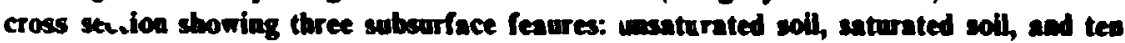
circular butied drums. The degree of shading increases with increasing loval sound speed. The white area from the surface to mid-depth is dry soil, the gray area below is an aquifer, and the dark circles above and below the water table are buried drums.

\subsection{TECHNICAL HIGHLIGHTS}

\subsubsection{Use of DOE Site Selecti..: Criteria for Screening Low-Level Waste Disposal Sites on the Oak Ridge Reservation}

D. W. Lee

R. H. Ketelle

I. H. Stinton

This study applied the proposet 5OE site selection criteria for low-level waste disposal sites to the Oak Ridge Reservation to evaluate their ease of application and to identify any difficulties

UCC-ND Engineering. 
arising during their application. Site selection is considered a two-stage process: site screening and site characterization. Site screening relies on reconnaissance data for identification of a preferred site, and site characterization relies on a detailed site investigation and analysis for evaluation of the site's capability to comply with the DOE performance objectives. The procedure used for site selection incorporates DOE site selection criteria, the needs of the developer, and the consideration of alternative sites.

The site screening methodology applies the DOE site selection criteria by dcfining a region of interest, identifying candicate areas within the region of interest, identifying a slate of candidate sites within the candidate areas, and identifying a preferred site from a slate of candidate sites. The site characterization methodology includes a preliminary investigation of site feasibility, a comprehensive field study, a laboratory analysis of field samples, a site monitoring program, and a pathways analysis.

The DOE site selection criteria were applied through site screening to the Oak Ridge Reservation. The reservation was defined as the region of interest, with DOE as the developer. The limited size of the reservation admits only the Conasauga and Knox Groups as viable geologic groups for consideration because of the limited soil thickness associated with the remaining groups. Five candidate area screening requirements were developed; they resulted in the identification of five candidate areas containing at least one poter.til site in each area. These area screening requirements are as follows:

I. Area should be outside the 100-year floodplain and wetlands.

2. Estimated soil thickness should exceed $10 \mathrm{~m}$ (30 ft).

3. Estimated unsaturated zone thickness should exceed $7 \mathrm{~m}$ ( $20 \mathrm{ft}$ ).

4. Area should be large enough to include at least one site that has an ar ive land area exceeding 80 ha ( 200 acres).

5. Area should be defined to be exclusive of any land previously utilized for the burial of waste.

Candidate site screening requirements were also developed; they contained four exclusionary requirements and five desirable features. These site screening requirements are as follows:

A. Exclusionary requirements:

1. Exclude areas with evidence of karst topography.

2. Exelude areas with a slope greater than $25 \%$.

3. Exclude areas that do not fall within a security boundary defined as

- $250 \mathrm{~m}$ from existing plants,

- $250 \mathrm{~m}$ from public roads, and

- $250 \mathrm{mi}$ from reservation boundary.

4. Exclude areas adjacent to residential development.

B. Desirable features:

1. Available area greater than 80 ha (200 acres).

2. Slope less than $10 \%$.

3. Easy access to site by road.

4. Site in close proximity to waste generators.

5. Utilities available for site development. 
Five candidate sites were identified: two sites in Bear Creek Valley and three sites on Chestnut Ridge. The site selection parameters used for preferred site identification were hydrology, geology. soils, land use, socioeconomics, and ecology /meteorology. Each criterion in the DOE site selection criteria is associated with at least one site selection parameter. Relative comparisons of the candidate sites for each site selection parameter were performed based on reconnaissance data. The candidate sites were ranked by expert opinion for each parameter and sunmarized in an overall ranking of candidate sites. The results of the investigation did not identify a preferred site with natural features that made it clearly the best site. The results of this study suggest that both Knox and Conasauga Group sites have deficiencies which detract from thcir suitability for low-level waste disposal and which must be addressed in the design of a low-level waste dispasal facility.

Application of the DOE site selection criteria using the generic methodology is qualitative and requires considerable judgment at each step. The development of the screening requirements, site selection parameters, and the definition of the region of interest most strongly influence the identification of a preferred site. Site deficiencies that require further consideration in the design of a facility were clearly identified as a result of using the site selection criteria for identification of a preferred site.

\subsubsection{A Model for Groundwater Seepage from Mill Tailings Ponds}

$$
\begin{array}{ll}
\text { F. G. Pin } & \text { R. D. Sharp" } \\
\text { A. J. Witten } & \text { E. C. Long }
\end{array}
$$

A computer code (MIGRAT) was developed to quantify the migration of moisture and multiple decaying and absorbed contaminants in the unsaturated zone. MIGRAT was specifically conceived tu assess the impacts of oper mine disposal of uranium mill tailings; however, the sode is general enough to allow its use in many problems related to shailow, subsurface waste disposal since it incorporates a number of desirable objectives and user-oriented features. These features include

- the capability to simulate one-, two-, or three-dimensional geometries without major changes in coding or input formats,

- the capability to accurately represent complex geometries and heterogeneous material properties,

- the capability to simulate systems with diversified and time-variable boundary conditions,

- the capability to accurately represent the moisture-dependent characteristics of the geological materials,

- the capability to provide worst-case solutions for contaminants migration, taking into account sorption and decay of contaminants,

- the use of the discrete cell (or integrated finite difference) method in order to explicitly preserve the flux terms as such at the boundary of the cells, and

- the use of a self-adjusting optimum time step to solve the highly nonlinear equations.

The model has been applied to a generic uranium mill tailings pit constructed with a clay-lined bottom and steep, unlined sidewalls. ${ }^{7}$ The migration of a two-contaminant system was modeled,

\footnotetext{
'Computer Sciences Division.
} 
assuming that neither contaminant decays and that only one contaminant is retarded. This study showed the anticipated result that moisture and contamination migrate slowly through the bottom clay liner and that, in this migration, concentrations of the retarded contaminant significantly lag the unretarded contaminant. This study also showed that the major pathway from the pit to the un' erlying water table is through the sidewall and that the time scales for this pathway are much siorter than those associated with the clay liner. More importantly, this study revealed that, because of the strong nonlinear character of the nydraulic properties of unsaturated soils, concentrations of the retarded contaminant may only slightly lag the nonretarded contaminant through this pathway and that contamination of the uppermost aquifer by the retarded contaminant may occur shortly after contamination by the nonretarded contaminant.

\title{
2.2.3 Use of Electromagnetic Tennim Conductivity Mensurements to Map Liquid Hazandous Waste Migration in Gromedwater
}

\author{
R. H. Ketelle and F. G. Pin
}

Electromagnetic conductivity measurements were used to map apparent ground conductivity in the vicinity of a liquid hazardous waste disposal site. An area of $\sim 12$ ha (30 acres) was surveyed. Approximately 600 conductivity measurements were obtained to prepare a condurtivity map of the site. Conductivity measurements in the area correlate with specific conductance measurements of surface water and groundwater samples. Contouring of the conductivity datis showed the precise location of contaminant migration pathways in the subsurface. A complex contaminant plume was defined by the conductivity survey (see Fig. 2.2). Conductivity values obtained reflected anisotropic characteristics related to local bedrock structure. Anisotropic characteristics and the use of different instrument configurations indicated semiquantitatively the depth of the high-conductivity zone and the direction of flow.

\subsubsection{National Inventory of Abandoned Mine Laad Problems}

R. B. Honea"
R. C. Durfee ${ }^{\dagger}$
R. M. Rush
R. G. Edwards ${ }^{\dagger}$
D. L. Wilson ${ }^{\dagger}$
C. H. Petrich

This project, which began in - ntember 1979, was completed in July 1983. It was a collaborative effort involving ORNL, the Tennessee Valley Authority (TVA), East Tennessee State University, and Lockheed Missiles and Space Company. The work in FY 1983 involved entering the final data submissions into the Inventory data base and writing a final report.'

In 1977, Congress passed the Surface Mining Control and Reclamation Act, which provided for the abatement of abandoned mine land problems through a reclamation program funded oy a

\footnotetext{
"Project Leader.

Computer Sciences Division.
} 


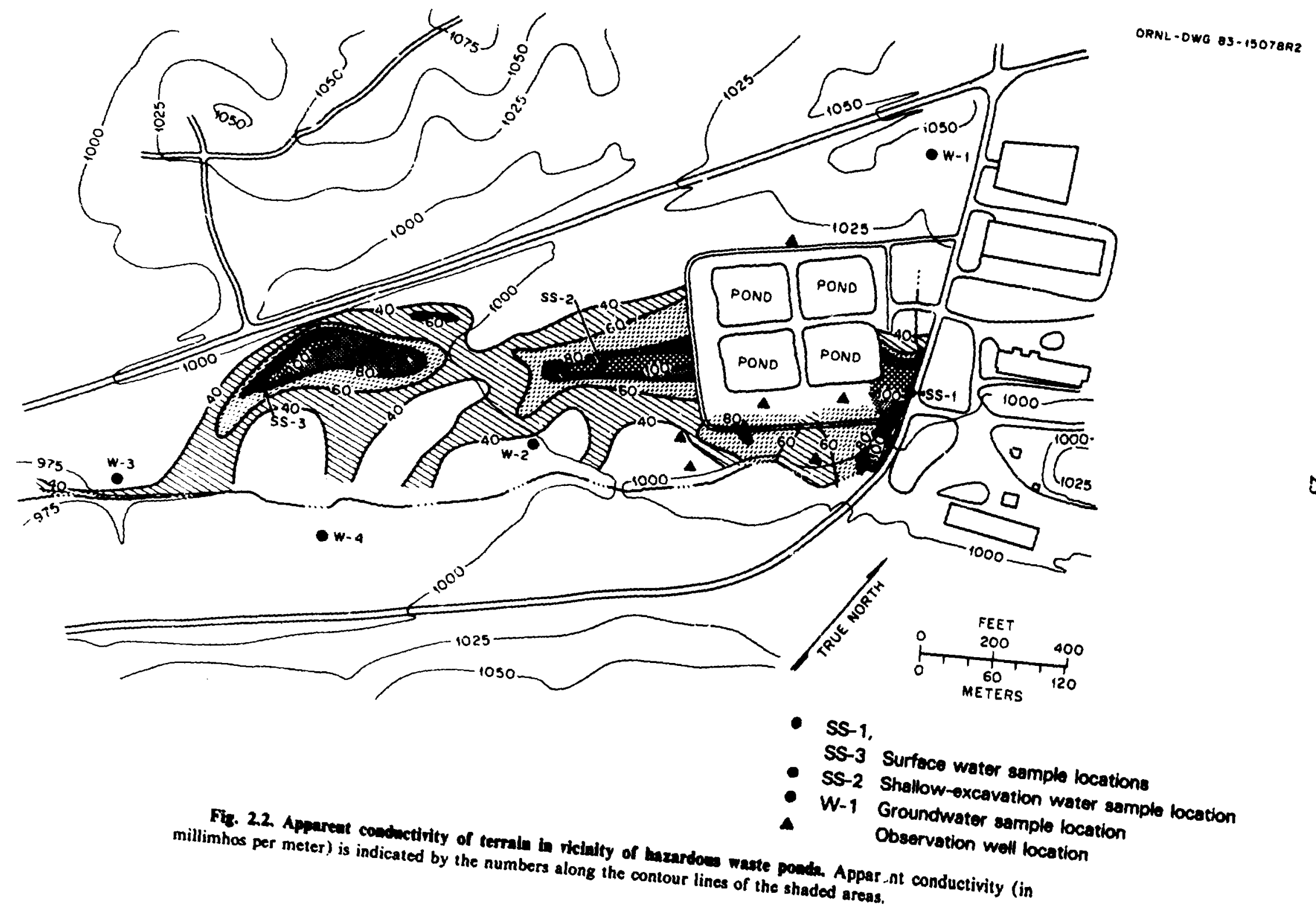


severance tax on current mining. This act also created the Office of Surface Mining (OSM) in the U.S. Department of the Interior to administer the abandoned mine land prugram and to assume other regulatory and research responsibilities. The Energy Division and Computer Sciences Division were given the responsibility to design, implement, and report the results of a national Inventory of the most serious problems associated with past mining practices. The main objective of the Inventory was to help the OSM and the states locate, identify, and rank abandoned mine land problems and estimate their reclamation costs. Although the design of the Inventory and the assembly of the computerized data base were done by ORNL, the field work of collecting the data was the responsibility of each state or Indian tribe under a cooperative agreement with OSM.

The basic unit for the data collection was the Problem Area. Each Problem Area is a specific location containing one or more abandoned mine land problems. A problem is any situation having an adverse effect on the health, safety, and general welfare of the public. For each Problem Area, the Inventory data base contains locational data, keywords describing the nature of the problem(s). an indication of the cost and time to reclaim the Problem Area(s), and a summary description of the Prublem Area. The data base may be searched in a variety of ways to produce an almost endless variety of reports.

The Inventory consists of information on 6137 Problem Areas; 24\% of the Problem Areas are in Pennsylvania, 19\% are in Kentucky, 9\% are in Ohio, and the remainder is divided among 32 other states and 4 Indian tribes. The problems occurring most frequently are those related to mine facility safety hazards, such as open shafts and portals, and hazardous abandoned equipment and facilities. The next most frequent are problems of water-related impacts, such as flooding and landslides, on structures and improved property. One of the importint findings of the Inventory is that the cost of reclaiming the Problem Areas ideniified in the Inventory is estimated to be $\$ 1.7$ billion, with an upper limit of $\$ 3.2$ billion. The severance tax on current mining is expected to produce a reclamation fund of $\$ 3$ billion over the 15 -year life of the program.

\subsubsection{Evaluation of Dispersion Modets for Use in Emergency Response Situations}

\section{F. C. Kornegay}

The objective of this study is to identify the available atmospheric dispersion models that provide the most accurate and reliable estimates of radioactive concentrations downwind of operating reactors in emergency situations. Results from this study will be used to develop criteria to implement these selected codes to produce the near-instantaneous estimates of downwind concentrations in support of the requirements specified in NUREG-0654. ${ }^{10}$

Candidate codes, representing four major classes of models, have been selected and analyzed. A review of these analyses was published in 1982." These codes have been evaluated against theoretical and field data and will be tested using additional field data. Based on these initial tests, the sophisticated, particle-in-cell codes produce no better results than simple puff-type codes. During feriods of steady wirds, the very simple Gaussian plume model performs as well as any code under study. However, during the periods of variable winds, puff-type codes do provide a more realistic estimate of ground-level concentrations. These findings, as well as a review of modeling uncertainty, are presently being reviewed and will be published in early 1984. To determine the 
usefulness of the candidate models in an emergency response mode, the real-time capabilities of each code are presently under study. The sensitivity of each code to variability in meteorological data inputs will be examined since the availability of data has been determined to be a limiting factor for some of the puff-type and the more sophisticated codes in this study. As a final teat, the cost/benefint trade-offs of each model type will be determined.

\subsection{Enviromental Analysis of the Operation of ORNL}

\section{J. W. Boyle"}
R. Blumberg
S. J. Cotter'
R. H. Ketelle
R. D. Roop
G. S. Hill ${ }^{\dagger}$
R. L. Kroodsmat
D. N. Secora
C. R. Kerky
D. W. Lee
W. P. Staub
R. C. Martin
R. E. Thoma

This study ${ }^{12}$ describes the ORNL physical plant, characterizes the existing environment, cites ORNL environmental management policies, discusses accident safety policy, atd presents an environmental analysis of the operation of the ORNL facilities in Bethel and Melton valleys. The analysis shows that the predominant effect of the continued operation of ORNL on the human environment is socioeconomic since ORNL contributes a major portion of the income of the area in terms of staff payroll. In order of significance, the impacts are (1) the ultimate effocts of the research and development results on society (not addressed is, this report), (2) the continuing major sociocconomic effects on the regional communities and the rest of the United States, and (3) the effects associated with dispersion of small amounts of materials that are released to the area environment.

The impacts associated with the releases of materials to the environment result from releases to the atmosphere and to White Oak Creck. The released materials may be grouped into two categories, radioactive releases and nonradioactive releases, which are assessed separately.

Nonradioactive releases to the air included gases and particulate emissions from the codl-fired steam plant, chemical vapors from a large number of hoods and other building exhausts, dust and exhaust from vehicular traffic, and cooling tower drift. Calculations on the nonradionctive components show that national ambient air quality standards are not exceeded for any of the criteria pollutants.

Radiological discharges to the atmosphere amounted to $1.87 \mathrm{PBq}(5 \mathrm{~S}, 500 \mathrm{Ci})$ of radioactivity in 1981; about $77 \%$ of this activity consisted of the noble gaesa, about $23 \%$ consisted of tritium, and a small amount consisted of ${ }^{131} \mathrm{I}(18 \mathrm{GBq}$, or $0.5 \mathrm{Ci}$ ). The population within an $80-\mathrm{km}$ ( 50 -mile) radius of ORNL is calculated to have received a s0-year dose commitment of 0.1 person-Sv (10 person-rem) to the total body, primarily from the tritium released, and 0.28 person-Sv (28 person-rem) to the thyroid from the ${ }^{131} 1$ released. The total body background s0-year dove

\footnotetext{
Project Leader.

'Health and Safety Research Division.

'Environmental Sciences Division.
} 
commitment to this same population is 1,100 person-Sv (110,000 person-rem). Therefore, ORNL releases to the air are equivalent to an $\mathbf{0 . 0 1 \%}$ increase in background radiation.

Water quality within portions of the White Oak Basin was found to be degraded with respect to chemical loading and to radioactivity. The public is excluded from this part of the basin. At White Oak Dam, where the discharge enters the public access domain, average concentrations for most water quality constituents were below EPA standards and criteria for the protection of aquatic life; cadmium and manganese were the exceptions, and mercury and nickel concentrations cocasionally exceeded criteria levels in 1981.

In 1981 the total radioactivity discharged to the Clinch River over White Oak Dam consisted of $0.11 \mathrm{PBq}(3,000 \mathrm{Ci})$ of tritium and $95 \mathrm{GBq}(2.6 \mathrm{Ci})$ of other radionuclides, $93 \%$ of which consisted of ${ }^{60} \mathrm{Co},{ }^{90} \mathrm{Sr}$, and ${ }^{137} \mathrm{Cs}$. Measurements at the mouth of White Oak Creek showed that the radioactivity bas averaged less than the concentration guide for water $\left(C G_{w}\right)$ in uncontrolled areas, about $30 \%$ for each of the past five years. The $\mathbf{C G}_{w}$ is a limit established for the protection of human healtb. Complete mixing is reached within a few kilometers below the confluence of White Oak Creek and the Clinch River. After dilution by flow in the Clinch River is taken into

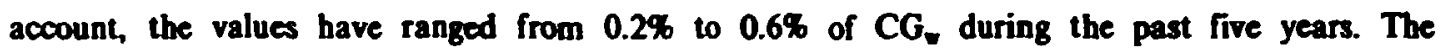
population 50-year dose commitment from drinking water from the Clinch and Tenneasee rivers was 0.038 person-Sv ( 3.8 person-rem), which is about $0.01 \%$ of the dose to the same population of 390 person-Sv (39,000 person-rem) from natural background radiation.

\subsubsection{Methodology for Estimating Fisheries Harrest}

\section{R. B. McLean}

An analysis of a severe radiological accident by the NRC requires estimates to be made of the fisheries harvest rates within an $80-\mathrm{km}$ (50-mile) radius of nuclear power plants. These rates are used in the analyses of liquid pathway consequences of potential accidents. The purpose of this study was to develop methodologies for estimating both commercial and recreational fisheries harvest rates for five major aquatic systems. These systems included (1) large rivers, (2) small rivers, (3) reservoirs, (4) marine coasts, and (5) the Great Lakes. In addition to identifying sources of existing fisheries data for each system, correlation coefficients of physical data (turbidity, degree-days, flowthrough, etc.) with standing stocks were also utilized.

The methodology is tailor-made for each system but, in general, consists of a blend of direct estimation through interpretation of fisheries data and indirect estimation using correlation analysis. Correlations may be between (1) standing stock and sport harvest, (2) growing season and production, (3) biomass turnover :ates and production, (4) total dissolved solids and standing crop, or (5) physical factors (age of system, turbidity, growing season) and sport fish harvests. An initial analysis and comparison with the methodology presently used by NRC indicate previous overestimates of marine recreational harvest by up to two orders of magnitude. Since such estimates are used to determine the potential effects of major reactor accidents, this discrepancy is significant.

\subsection{RESEARCH UTILIZATION}

The research utilization of the work carried out by the Environmental Impect Section can be characterized in terms of technology and information transfer. In general, that work involving the 
preparation of EIAs and EISs is in support of a sponsor's need to meet the requirements of NEPA. Therefore, such documents, both informational and analytical, are used to inform the public of the environmental consequences of a major federal action. The analyses required to arrive at and define such consequences reflect the state of the art and the expertise of the staff. Therefore, such worts operate as a transfer mechanism to the less informed and less expert segment of both the public and the scientific world.

As an exercise attendant to our NEPA work, the staff also prepares informational documents on specific problems encountered. These serve as vehicles for the transfer of research results and/or methodology to the general public or, more specifically, to the commercial sector that has need of such information. Examples of such reports prepared in FY 1983 are as follows: A Review of Corrective Measures to Stabilize Subsidence in Shallow-Land Burial Trenches," Guidance for Disposal of Uranium Mill Tailings: Long-Term Stabilization of Earthen Cover Materials,' Use of Electromagnetic Terrain Conductivity Measurements to Map Liquid Hazardous Waste Migration in Groundwater, and A Process for Locating Shallow Land Burial Sites for Low-Level Radioactive Waste. ${ }^{13}$

In a broader sense, the staff, in carrying out its analyses, must act in a research capacity. In those areas of impact analysis where precise tools and models are not available for prediction of impacts, the staff attempts either to develop such tools and models or to modify extant tools and models to fit the case at hand. Examples of such research were presented in Sect. 2.2.

One specific example of research arising from our NEPA work was presented in Sect. 2.2.2. In this case the NRC funded the development of a computer code (MIGRAT) to enable the assessment of impacts of uranium mill tailings disposal. The computer code developed for this specific purpose is being used in a generic sense to address possible groundwater contamination for shallow subsurface waste disposal.

Another example was presented in the introduction (Sect. 2.1), where our initial findings on the use of sonic tomography for use of site characterization are descr. hed. Again, this is a spin-off frum the identification of research areas where adequate tools for predicting impacts are not available. In each case covered in this report, the staff has used their previous experience to develop methods for doing specific tasks more quickly and efficiently.

\subsection{REFERENCES}

1. L. D. Voothees et al., Guidance for Disposal of Uranium Mill Tailings: Long-Term Stabilization of Earthen Cover Materials, ORNL/TM-8685, NUREG/CR-3199, Oak Ridge National Laboratory, June 1983.

2. J. D. Nelson, R. L. Volpe, R. E. Wardwell, S. A. Schumm, and W. P. Staub, Design Considerations for Long-Term Stabllization of Uranium MIII Tallings Impoundments, ORNL-5979, NUREG/CR-3397, Oak Ridge National Laboratory, September 1983.

3. J. B. Cannon et al, Background Information and Technical Basls for Assessment of Environmental Implications of Magnetic Fusion Energy, DOE/ER-0170, U.S. Department of Energy, Washington, D.C., August 1983.

4. R. D. Roop et al., A Review of Corrective Measures to Stablize Subsidence in Shallow-Lond Burial Trenches, ORNL/TM-8715, Oak Ridge National Laboratory, May 1983.

5. D. W. Lee et al., Use of DOE Site Selection Criteria for Screening Low-Level Waste Dispasal Sites on the Oak Ridge Reservation, ORNL/TM-8717, Oak Ridge National Laboratory, September 1983. 
6. A. J. DeVaney, -A Filtered Backpropagation Algorithm for Difiraction Tomography," Ultrasonic Imazing 4. 336-350 (1982).

7. F. G. Pin, A. J. Witten, R. Sharp, and E C. Long, A Numerical Study of Unsoturcted Flows and Seepage of Contaminaus from Subgrade Mill Tailings Disposal Areas Equipped with Botrom Clay Liners, ORNL/TM-8822, Oak Ridec National Laboratory, July 1983.

8. R. H. Ketelle and F. G. Pin, Use of Electromagnetic Terrain Conductivity Mearurements to Map Liquid Hezardous Waste Migration in Groundwater. ORNL/TM-8865, Oak Ridge National Laboratory. November 1983.

9. R. B. Honea at al., A National Invensory of Abandoned Mine Land Problems: An Emphasis on Health, Safety, and General Welfare Impacts, OSM/TR-4/83, prepared by Oak Ridge National Laboratory and the Ternessee Valley Authority for the U.S. Department of the Interior, Office of Surface Mining, August 1983.

10. Criteria for Preparation and Evaluation of Radiological Emergency Response Plans and Preparedmess in Support of Nuclear Power Plants, NUREG-0654, FEMA-REP-1, U.S. Nuctear Regulatory Commixsion, November 1980.

11. W. S. Lewelken, R. I. Sykes, and D. Oliver, Evaluation of MATHEW/ADPIC As a Real-Time Dispersion Model, NUREG/CR-2199, U.S. Nuctear Regulatory Commixion, March 1982.

12. J. W. Boyle et al., Environmental Analysis of the Operation of Oak Ridge National Laboratory (X-10 Site), ORNL-5870, Oak Ridge National Laboratory, November 1982.

13. W. P. Staub, P. R. Intemann, J. B. Cannon, L. E. Stratton, C. F. Nern, and K. L. Falooner, A Process for Locating Shallow Land Burial Sites for Low-Level Radioactive Waste, DOE/LLW-16T, U.S. Department of Energy, National Low-Level Radioactive Waste Management Program, March 1983. 


\title{
3. Regional and Urban Studies Section
}

\author{
R. M. Davis
}

\subsection{INTRODUCTION}

The Regional and Urban Studies (RUS) Section is primarily concerned with the analysis of energy supply and use at the urban and regional level. The section consists of four groups, including Social Impacts Analysis, Resource Analysis, Transportation Energy, and Emergency Planning. The highlights from the section's work will be described under cach of these four areas.

During FY 1983 the RUS Section received major sponsor support from various offices in the U.S. Department of Energy (DOE), particularly Conservation and Renewable Energy, Fnvironmental Protection, Safety and Emergency Planning (EPSEP), and the Energy Informatio Administration (EIA). Transportation programs received increased support from the U.S. Department of Transportation (DOT), specifically the Federal Highway Administration. Resource and mineral assessments were supported by the U.S. Department of the Interior's (DOI's) Bureau of Land Management and Minerals Management Service. Support for international energy assessments was provided by the Agency for International Development (AID). Work on the technical and socioeconomic feasibility of alternative shelter designs continued, with support from DOE/EPSEP as well as from the Federal Emergency Management Agency. In addition, new programs in mobility fuel forecasting, fuel technolsgy planning, and facility energy conservation were supported by the Departmeric of the Navy.

The section's research into social analysis and assessments has continued to expand (Sect. 3.2), particularly the energy conservation evaluation programs for the DOE Office of State and Local Assistance Programs. The main thrust of this work has been to help DOE and its constituent state and local agencies develop, transfer, and apply sound methods for evaluating the effectiveness of energy conservation programs and calculating energy savings attributable to these programs. Energy savings indices (energy use per unit of service) originally developed by DOE were refined for 17 state conservation program measures, a computer program was created to carry out the corresponding calculations, and CY 1982 energy savings were estimated for states. A systematic review was conducted and a decision paper prepared for DOE on alternative approaches for assessing energy conservation program impacts.'

For many years, DOE has encouraged energy conservation by providing funds to states for energy conservation activities through the State Energy Conservation Program (SECP) and the Energy Extension Service (EES). To highlight the results from these efforts, DOE asked Oak Ridge National Laboratory (ORNL) to conduct case studies of four residential and four local government 
programs that had resulted in innovative actions to save energy. The four state residential ecergy conservation program studies ${ }^{2}$ were as follows: (1) Otlahoma's energy education project for lowincome and elderly persons, (2) Oregon's Master Conserve program, (3) Virginia's workshop for beating oil dealers and contractors, and (4) three Maine energy education projects- the Energy Bus. Energy Conservation Month, and the Home Energy Checkup. The four local government programs $^{3}$ examined were as follows: (1) the Austin, Texas, Comprebensive Community Energy Management Program; (2) the New Castle County, Delaware, energy action, which included extensive in-house energy management efforts and the enactment of a stringent energy-conserving building codes (3) the multifaceted public avareness campaign in Illinois entitled Project Peoria; and (4) the Rock Hill, South Carolina, Energy Futures Conference. The lessons learned, particularly regarding the institutional arrangements required for successful conservation programs, have been disseminated through publications and workshops.

In another task, ORNL conducted a pilot study that could affect the allosation of $35 \%$ of the SECP funds. This study analyzed a proposed rule claange that wouk' have replaced estimated projections of heat energy savings with actual savires reported by states and validated by DOE at the end of each year. The ORNL study group considered the proposed rule change to be peither feasible nor practical given the quality of the data available and the dificulty in attributing heat energy savings to the specific characteristics of the SECP. Related follow-up work to develop a more feasible approach for allocating future conservation program funds is planned. In another task, ORNL attempted to analyze the energy conservation impact of building codes (ASHRAE 90-75). ${ }^{4}$ The average thermal efficiency of single-family homes was found to have improved from 1976 to 1979 in each of the 48 contiguous states. However, a strong correlation between the establishment of building codes and standards and thermal efficiency improvements could not be proven.

Work also continued on the Energy-Related Inventions Program (ERIP) (Sect. 3.2.2), which is join:ly administered by DOE and the U.S. Department of Commerce. This program is designed to award grants to independent inventors and small businesses that have promising energy-related inventions. Our involvement in ERIP has also provided valuable experience in the evaluation of the technology transfer process. We are building on this experience to help DOE's Building Thermal Envelope Systems and Insulating Materials (BTESIM) Program (see Chap. 6, Sect. 6.1.5) and the Department of the Navy develop improved programs in technology transfer. In a related technology utilization effort, our staff is assisting with the design of an experiment in Athens, Tennessee, to test the technical feasibility and customer response to using load management strategies in supplying electric power to communities (see Chap. 6, Sect. 6.2.3.1).

Resource analysis and mineral assessments have been a traditional area of work in the RUS Section. Our work has diversified, however, to include international as well as domeatic assessments. Internationally, a team of energy specialists from this section and others cunducted an in-depth assessment of energy options for the West African country of Liberia (see Chap. 7, Sect. 7.2.1). Domestically, work for DOI toward expanding the use of ORNL's wilderness assessment methodology was continued; an intensive workshop was held to transfer this methodology to geologists involved in uranium assessments. We also are applying our ascessment methodology to several candidate wilderness areas in the state of Utah. In addition, a team of resource analyst. assisted the Minerals Management Service in developing improved guidelines for establishing mineral lease values for royalty purposes (Sect. 3.3.1). 
Transportation energy analysis has continued to expond during the past year. Our work or the analysis of transportation energy usc patterns for all transport modes has continued, with support from DOE's Office of Vehicke and Engine Research and Development. We also continued the development of improved transportation sector energy demand models for EIA (Sect. 3.4.1). Work continued on two major programs supported by DOT's Federal Highway Administration to develop simplified computer software for using urban traffic system models (Sect. 3.4.2) as well as a related experimental field program to teat the on-road fuel efficiency of a variety of vehicles in the U.S. fleet (Sect. 3.4.3). For AID, we consulted with the Government of Tunisia on transportation energy use in that country. With sponsorship from DOE Nuclear Programs and the U.S. Army's Office of Toxic and Hazardous Waste, an analysis of alternative rail and bighway routes for shipping nuclear and other hazardous materials was continued.

The fourth major area of research in the RUS section is emergency planning. Our major effort has involved research into the potential technical and institutional problems associated with earthcovered shelters (Sect. 3.5.1). With sponsorship from DOE/EPSEP, work also continued on the evaluation and developinent of improved plans for a coordinated federal, state, and local agency response to radiological emergencies. In two related emergency planning studies conducted for the U.S. Nuclear Regulatory Commission (NRC), ORNL analyzed the organirational interface between on-site and off-site personnel at nuclear power plants and also investigated the potential role of human factors in incident alert classification and off-site notification at reactor sites under emergency conditions (Sect. 3.5.3).

\subsection{SOCIAL ANALYSIS AND ASSESSMENT HIGHLIGHTS}

R. B. Braid"
L. G. Berry
A. M. Fullerton
E. G. Llewellyn
M. L. Rorke'
R. Bolin ${ }^{\dagger}$
M. L. Johnson
E. Peelle
M. Schweitzer
L. M. Bronfman
D. W. Jones
S. F. Rayner
E. J. Soderstrom
S. A. Carnes
S. J. Liebowitz
J. H. Reed
J. H. Sorensen
N. E. Collins
M. N. Lintz
L. W. Rickert
A. H. Voelker
E. D. Copenhavert

\subsubsection{Reatartine Three Mile Island Unit 1: Social and Psychological Impacts}

On January 7, 1982, the U.S. Court of Appeals for the District of Columbia voted 2 to 1 in favor of a contention filed against the NRC requesting the consideration of paychological health effects and community well-being impacts of restarting Three Mile Island Unit 1 (TMI-1). NRC was ordered to prepare an environmental assessment to determine whether an environmental impact statement on the social and psychological impacts was necessary. Research was conducted by thi:

\footnotetext{
'Group Lender.

'New Mexico State U...ं rersity.

${ }^{t}$ Health and Safety Research Division.

T we University of Tennescec.

'Mohawk Research Corporation, Chicago.
} 
group to provide input for the preparation of an environmental assessment. Although the Supreme Court ever:ually ruled that an assessment was not required, the issue is still of greal scientific interest.

The purpose of the work was to define why impacts may or may not occur, to define a range of social and psychological effects that could accompany a decision about whether or not to restart TMI-I, and to make a preliminary assessment of how impacts could be mitigated. ${ }^{5}$ The scope of the work was focused on community-level impacts and not on impacts on specific individuals, although the two are related. The research did not attempt to predict the exact nature of impacts that will occur nor the precise level. Both are beyond the capabilities of current scientific nractice.

A literature review was conducted which identified nine general social factors that help expiain why impacts will or will not occur (Fig. 3.1). Focus-group discussions confirmed that these are relevant factors that can help explain the cognitive basis for impacts associated with the issue. Although the research cannot predict the magnitude of impacts, the literature review and focus-

ORNE - DY.G 82.15008A

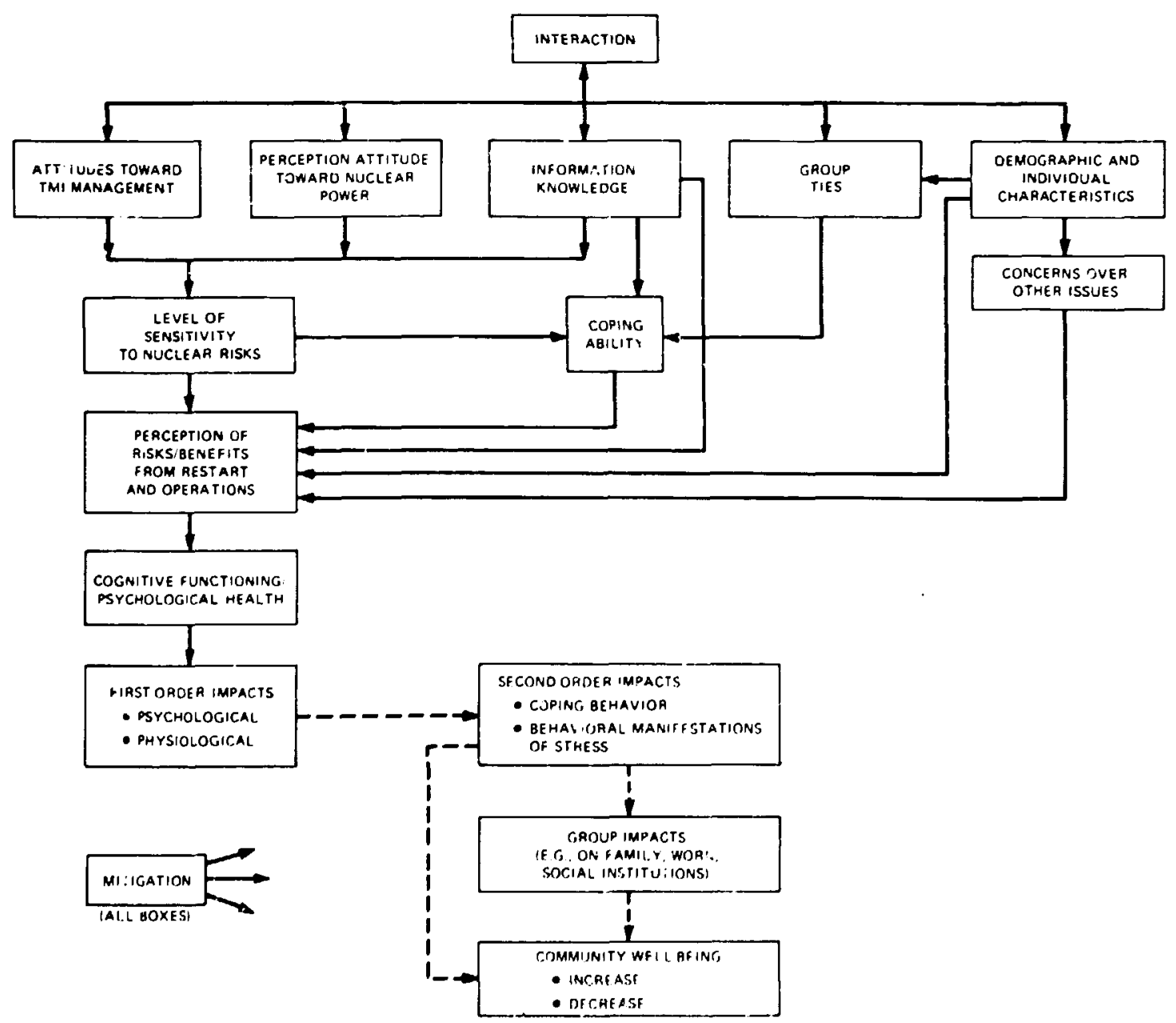

Fig. 3.1. Social factors and interaction which betp explain why impacts occur. 
group discussions helped to define relevant types of impacts that could occur. The most likely effect is an increased level of community and interpersonal conflict resulting from extreme polarization over the issue. Other impacts likely to occur, but at unknown levels, include an increase in stress and its related effects, a change in levels of residential satisfaction, a change in local economic conditions, and increased migration.

Impacts, however inevitable given the situation, can be altered through mitigation. Although the level of prevention cannot be predicted, it is possible to identify the types of mitigation that can be effective in reducing impacts. The identification of potential mitigation strategies is based on a review of relevant experiences, data from the profiling, and an analysis of how particular mitigative measures can alter potential causes of impacts. These suggest a community-based strategy for implementing a mitigation scheme as well as a broad range of possible measures that could be used to reduce impacts.

\subsubsection{Energy-Related Inrentions Program}

The ERIP provides support to independent inventors and small businesses with promising energy-related inventions for the purpose of moving these inventions closer to the marketplace. The program is small, with a budget of about $\mathbf{5 5}$ million per year, and is jointly administered by DOE and the U.S. Department of Commerce, National Bureau of Standards (NBS) (Fig. 3.2). Since ERIP's inception in 1975, DOE has awarded grants totaling $\$ 12.8$ million for 165 of 208 inventions recommended by NBS.

The program was recently evaluated at ORNL, with the following conclusions. ${ }^{6,7}$

1. The evaluation process at NBS has been successful in identifying technically and economically feasible inventions.

2. The success rate for the program is about equivalent to the reported success rates of private venture capital firms.

3. The prograrin is supporting inventions at a point in their development when they are supported by neither the venture capital community nor industry.

4. The one-time DOE grants and the associated ERIP support to inventors have been successful in readying inventors for subsequent financing from the private sector.

Of the 165 inventions, 46 have been able to acquire subsequent financing from a variety of sources, accumulating a total of $\$ 48,855,000$. Further, 35 of the inventions have reached the marketplace, and their cumulative sales to date total $\$ 178$ million. An additional 10 inventions are now starting into production. The combined investment and sales figures yield a leverage ratio for ERIP funds of 17.5:1. This leverage ratio compares very favorably with the 10:1 ratio of the National Science Foundation's Small Business Innovation Research Program and the Department of Commerce's Technology Commercialization Centers.

Some 756 jobs have been, created directly by production related to supported inventions. This total does not include additional spin-off jobs attributable to the inventions such as component and material suppliers, jobbers, franchisees, and distributors. Of the 35 inventions on the market, 25 have direct energy savings benefits. Based on available estimates for 11 of the 25 inventions funded through the ERIP, energy savings were estimated at 3.16 trillion Btu $\left(3.33 \times 10^{15} \mathrm{~J}\right)$ per year, equivalent to $545,000 \mathrm{bbl}$ of oil worth more than $\$ 15$ million at current prices. 


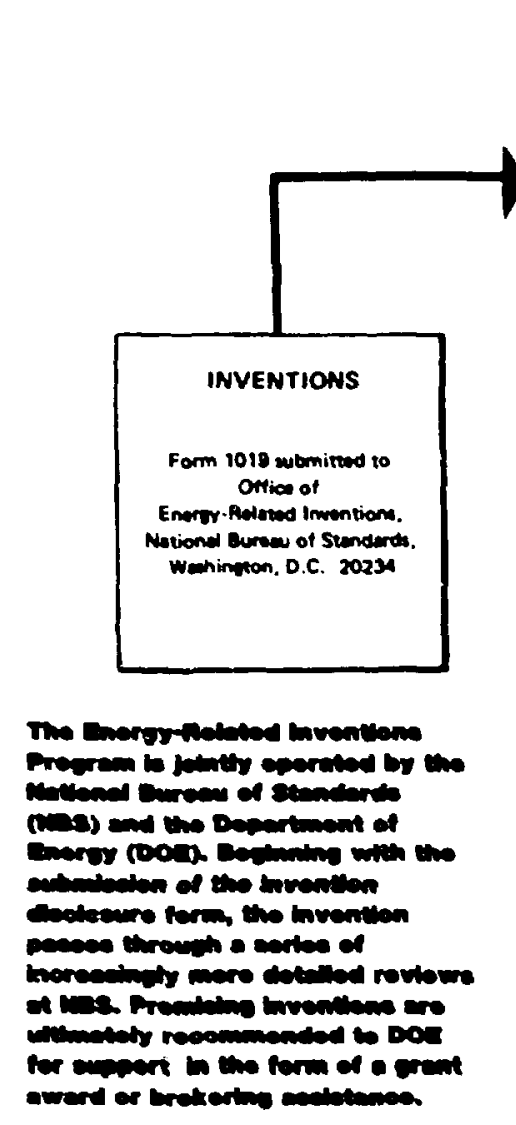

NBS EVALUATION

Dixclowers Reverom

NBS invews inventions to determine eceplabinity lor

mir lied anu not obviously

A IN.UN I ACCEPTABLE

INVE NTIONS MONR to

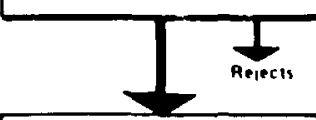

Fincicsure Eveduetion

Brist lectricacal opinions are

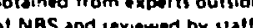

"PROMISING" INVENTIDNS

move 10

DoE eVALUATION

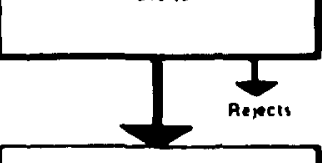

Second. Stem Evalustion

in deptin ansiysur of invention.

tinal report. II tirst stroge

atustion is conlirmed.

DOE $Y$ Enaror Aolsind Inven

IIOns Proorsom, Smalliseno

Tectnoloor Brench

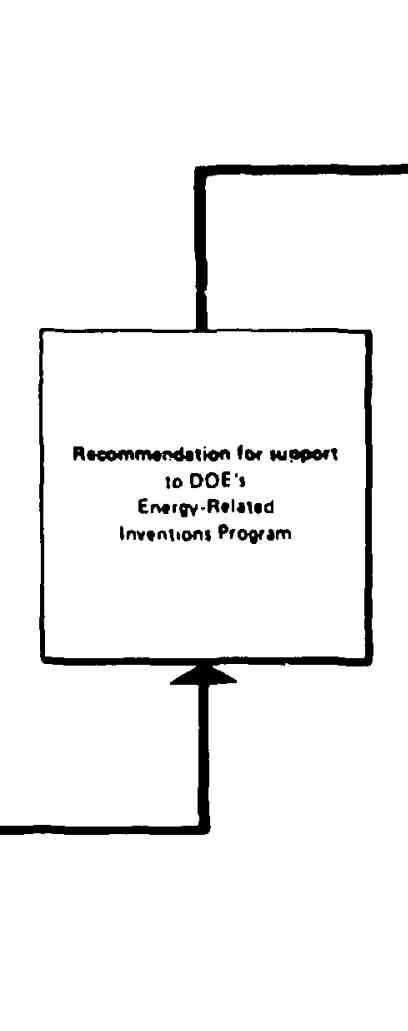

Alcivenment of imsention 10

DOE Coordinater
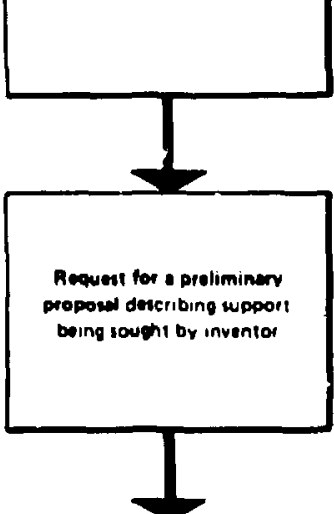

BAOKEAINO ASSISTANCE DR GAANT AWARO 4

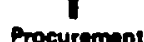

Procurominn 4

4

Notification

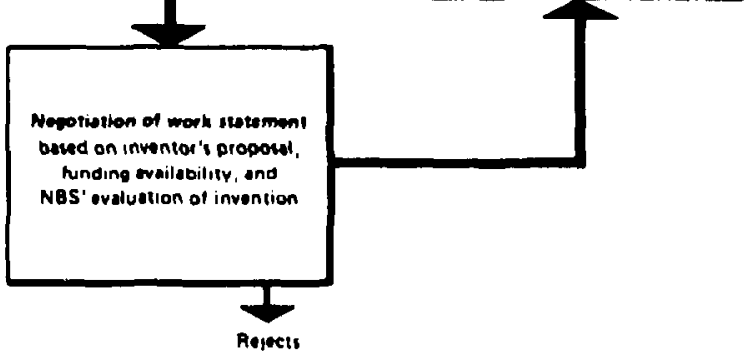

Fi. 3.2. Energy-Reluted Invention Progran procen. 


\title{
3.3 RESOURCE ANALYSIS AND MINERAL ASSESSMENT HIGHLIGHTS
}

\author{
J. E. Dobson"
}

$\begin{array}{lll}\text { T. J. Abraham } & \text { B. F. Hobbs } & \text { C. R. Petrich } \\ \text { W. F. Barron } & \text { D. W. Jones } & \text { D. E. Reilly } \\ \text { R. M. Davis } & \text { C. R. Kerley } & \text { L. W. Rickert } \\ \text { C. S. Daw } & \text { M. E. Lackey } & \text { J. H. Sorensen } \\ \text { E. C. Fox } & \text { R. Lee } & \text { A. H. Voelker } \\ \text { E. L. Hillsman } & \text { E. B. Lewis } & \text { G. P. Zimmerman }\end{array}$

\subsubsection{Minerals Valuation for Royalty Purposes}

ORNL supported the Minerals Management Service (MMS), DOI, in its rule-making and product valuation and royalty guidelines for lessees of federal lands. To compute a royalty payment, the mineral must be assigned a fair market value.

The valuation of gas and of products obtained from gas is more complicated than that of other minerals because of gathering. transporting, and processing before sale, the costs of which may be allowable deductions, and because of precedent-setting court rulings that suggest a separate set of criteria for Indian tribes. In certain situations, the ORNL studies suggested that MMS may require an adjustment to the value of the gas to account for differences in heat content, processing costs, extraordinary revenues related to the sale of gas, or other special circumstances.

Since royalties should be based on the value of the minerals at the time of the lease, certain processing and transportation costs should be subtracted from the lessee's gross proceeds before a royalty is assessed. Using a revenue-requirements approach, a formula for a suitable value of the processing (or transportation) cost allowance was developed as follows:

$$
A_{j}=(1-t)\left(O_{j}+D_{j}+i_{b} \rho_{b} V_{j}\right)+i_{s} \rho_{s} V_{j}-c I_{j} .
$$

where

$$
\begin{aligned}
A_{j} & =\text { the allowance in year } j, \\
t & =\text { the marginal tax rate, } \\
O_{j} & =\text { the operating expenses, } \\
D_{j} & =\text { depreciation, } \\
V_{j} & =\text { the outstanding unrecovered investment, } \\
i_{b} i_{s} & =\text { the debt incerest rate and rate of return } \\
f_{b} f_{s} & =\text { to stock, respectively, } \\
c & =\text { respectively, } \\
I_{j} & =\text { the investment tax credit, }
\end{aligned}
$$

\footnotetext{
Group Leader.

The University of Tennessee.

tEngineering Technology Division.

'Economic Analysis Section, Energy Division.

'Information Division.
} 
A comparison of this formula with another under consiteration by MMS revealed that significant differences in the cost allowances may occur-thus affecting royalty revenues-depending on the method ised to calculate the allowances (Table 3.1).

Table 3.1. Nenerical example to compare two methods

of calculatio the procescing illowne

for royalty proses

\begin{tabular}{ccc}
\hline \multirow{2}{*}{$\begin{array}{c}\text { Year allowance } \\
\text { in effect }\end{array}$} & \multicolumn{2}{c}{ Allowance $\left(10^{6} 5\right)$} \\
\cline { 2 - 3 } & ORNL method & Preliminary MMS method \\
\hline 1 & 3.12 & 2.87 \\
2 & 2.74 & 2.87 \\
3 & 2.56 & 2.87 \\
4 & 2.38 & 2.87 \\
5 & 2.20 & 2.87 \\
\hline
\end{tabular}

\title{
3.4 TRANSPORTATION ENERGY ANALYSIS HIGHLIGHTS
}

\author{
D. L. Greene
}
M. C. Holcomb
R. N. McGill
L. Till ${ }^{\dagger}$
J. N. Hooker
B. E. Peterson
P. S. Hu
G. F. Roberts

\subsubsection{Intermediate Future Forecasting System: Transportation Models}

The Transportation Energy Group developed a new set of transportation sector energy demand models for EIA's Intermediate Future Forecasting System (IFFS). The IFFS models are used by EIA's Longer Term Information Division to produce U.S. energy demand forecasts over a ten-year period. ORNL's new models are now being used in a forecasting exercise, the results of which will be published in the 1983 Annual Energy Outlook.

The transportation models include automobile, single-unit truck, combination (tractor-trailer) truck, and commercial airline energy use. ORNL designed the models to be compact and efficient so that they would be consistent with the philosophy of the IFFS system design. That philosophy is to use the least complex model possible which still captures the major factors to which the system is sensitive. The challenge is, therefore, to create models that are simple, yel capture the essential structure and interrelationships of the energy demand system. One way to illustrate this idea is to note that the highway models (autnmobile and single-unit and combination trucks) contain 12 basic econometric equations plus necessary identities, forecast fuel economy, vehicle travel, and fuel use

\footnotetext{
Group Leader.

'Computer Sciences Division.
} 
for each of the three vehisle types for gasoline and diesel fuels (18 basic, forecasted variables) but require only four exogenous inputs: price of gasoline, price of No. 2 distillate, personal disposable income, and gross national product.

The highway model design uses a combination of both structural and reduced-form modeling approaches. The key components are equations for forecasting fleet fuel economy by fuel type, shares of vehicle travel by fuel type, and vehicle travel, all by each of the three vehicle types (Fig. 3.3). The model is structural in the sense that it derives fuel consumption by forecasting vehicle travel and vehicle efficiency explicitly and calculates fuel use by the identity

$$
\text { Fuel use }=\frac{\text { vehicle travel }}{\text { efficiency }} \text {. }
$$

ORNL - DMG BA A376

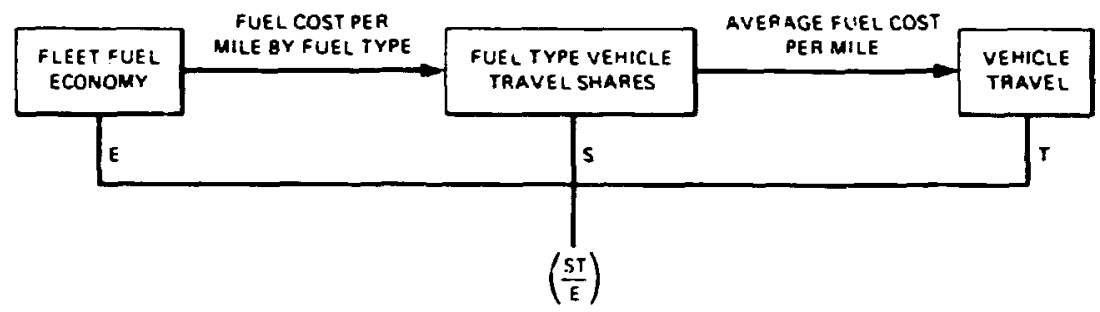

Fig. 3.3. Fued consanption by velicle type and feel type.

The model is reduced form in that the rather complex process of capital stock turnover which determines fuel economy and the diesel/gasoline fuel shares is represented by two simple equations: one for fleet fuel economy and one for diesel travel share. Perhaps the most interesting equations are those for fleet fuel economy. Very few attempts have been made to econometrically estimate fleet fuel economy, and hose who have tried have been frustrated either by inadequate historical data 9 or by failure to account for the influence of government regulations. ${ }^{10}$ The approach used in ORNL's mojel represents fleet fuel ezonomy as a lagged adjustment process. New-car gallons per mile (NGPM) is assumed to be a linear function of gasoline price and a time trend,

$$
\operatorname{NGPM}(t)=a+b \text { price }(t)+c \text { trend }(t),
$$

where $a . b$, and $c$ are constants to be estimated. Fleet fuel economy is a weighted average of this year's new-car fuel economy and last year's fleet fuel economy,

$$
\operatorname{GPM}(t)=a \operatorname{NGPM}(t)+(1-a) \operatorname{GPM}(t-1),
$$

where $0<a<1$. This simplified calculation of fleet efficiency is equivalent to assuming that new cars account for a constant fraction of total car travel. Substituting Eq. (1) into Eq. (2) results in the following lagged adjustment equation in fleet average gallons per mile:

$$
\operatorname{GPM}(t)=a a+a b \text { price }(t)+a c \text { trend }+(1-a) \operatorname{GPM}(t-1) .
$$


The equation was extimated on the basis of a combination of historical data for 1970 to 1982 and forecasts through 1995 from a larger, comp'ex engineering model of vehicle fuel economy developed by Energy and Environmental Analysis, Inc." The EEA model uses information on manufacturer plans and the cost-effectiveness of various fuel economy technologies to make detailed projections of new-car and fleet fuel economy by market segment. The time trend variable used is a ramp function rising linearly from 0 in 1977 to 8 in 1985 (the government's Corporate Average Fuel Economy Standards for new cars began in 1978 and rise to $27.5 \mathrm{mpg}$ in 1985), remaining constant thereafter. Estimation of the model resulted in a long-run price elasticity of fleet fuel economy of only - 0.1. Of far greater importance in determining fuel cconomy through 1995 is the time trend variable, whose midpoint long-run elasticity was 0.35 . This variable is more difficult to interpret; in principle, it may represent technological improvement as well as the force of fuel economy regulation. The estimatod value of $a, 0.15$, is quite reasonable, indicating that new cars account for about $15 \%$ of total car miles.

The ORNL models were provided to EIA as a "self-documenting" package comprised of machine-readable data bases used to estimate the equations, an annotated programming code that performs the estimation, and an annotated model simulation code that implements the extimated equations. This package enables EIA staff to reproduce the modeling process exactly, from data to forecasts, with a minimum of effort.

\subsubsection{Integrated Traficic Data System}

Over the past 20 years the Federal Highway Administration and others have developed a number of computer programs for use by traffic engineers in evaluating proposed traffic control strategies. These programs have proven to be effective tools in the development and evaluation of traffic systems since they allow a more thorough analysis of proposed designs and thus lead to reduced costs in planning and implementation. Additionally, they allow traffic engineers to improve the efficiency of traffic flow, thus reducing motorist delay, operating costs, and energy consumption.

Because these models have been designed for implementation and use on large mainframe computers, they typically use fixed card image input files that are difficult to construct and wark with. Largely for this reason, many of today's traffic engineers find that these model: : inconvenient to use and thus tend to underutilize them at present. The purpose of the Integrated Traffic Data System (ITDS) is to encourage traffic engineers to use these mainframe models by providing an easy-to-use interface through the use of microcomputers.

Figure 3.4 shows how this microcomputer-based system will operate. The user will maintain a traffic data base locally on a desktop computer system using a commercial data base management system. The software developed by ORNL will allow the user to easily construct card image files by answering "menu"-generated questions and by editing computer-generated forms that appear on the microcomputer's screen. The resulting data files can be transmitted via telephone lines to remotely located mainframe computers, where the appropriate traffic models reside. Output can then be retrieved in a similar manner and analyzed locally or stored back in the data base.

One oi the challenges in designing this system has been to develop a data model that is flexible enough to accommodatc the wide range of data needs of the nine traffic models to which the system will interface. These range in complexity from simple intersection analysis models to complete network simulation and optimization models. In addition, the terminology used varies 


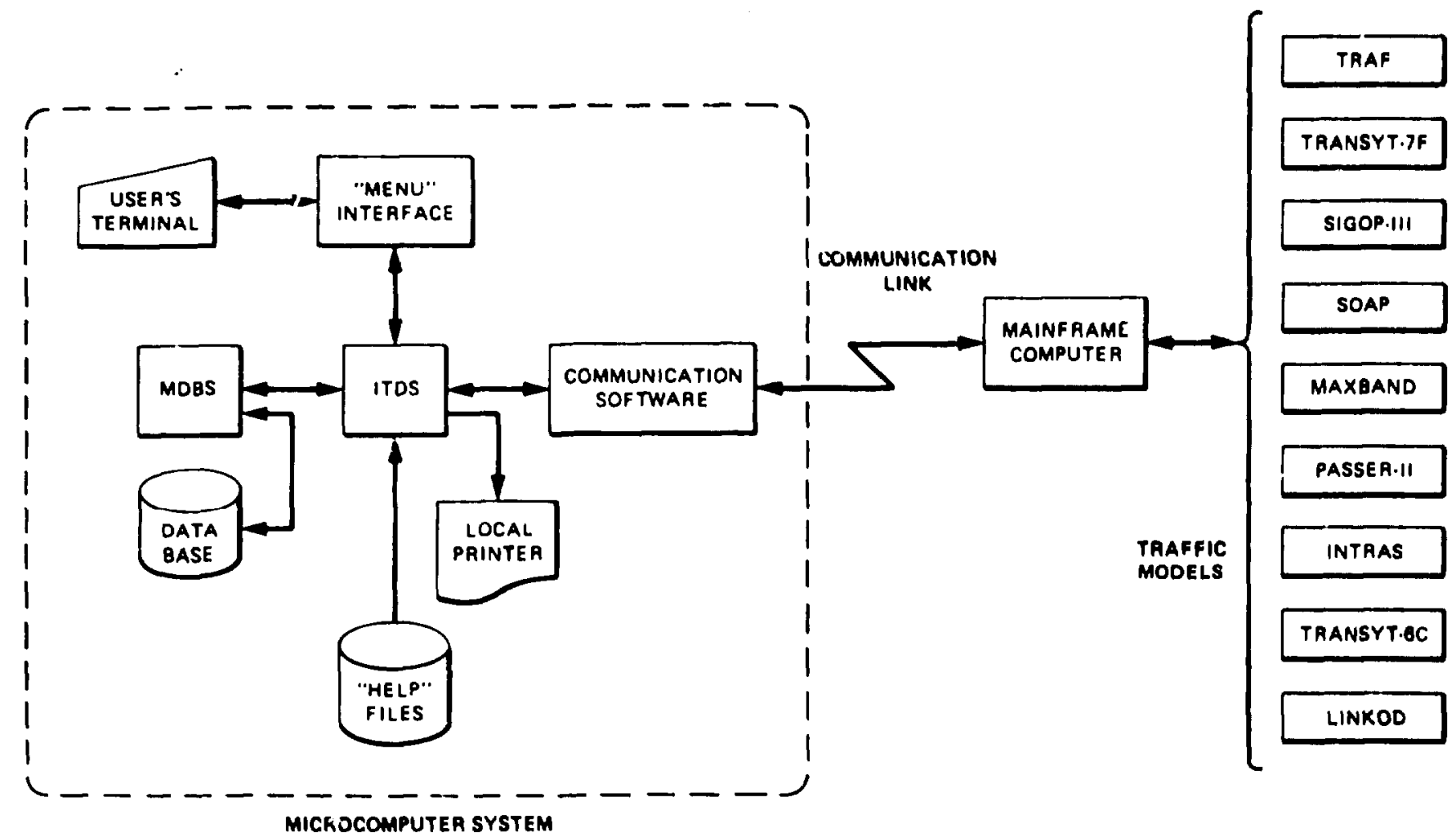

Fis. 3.4. Orerview of the Incezated Trame Data Syatcon. 
from model to model. Some models use the "link" consept to represent a unidirectional street segment; others allow the use of multiple "links" within a street, for example, to model separate movements of buses or carpools.

The technique used has been to assemble individual listings of the data requirements for each model and then merge these into a combined view of the data base, resolving discrepancies as they arise. Figure 3.5 shows a tentative data base schema representing all of the data records and the interrelationships that exist among them. This schema provides the main input to the CODASYLtype data base management system that will be ised to store the data.

OPAL DWG 840324A

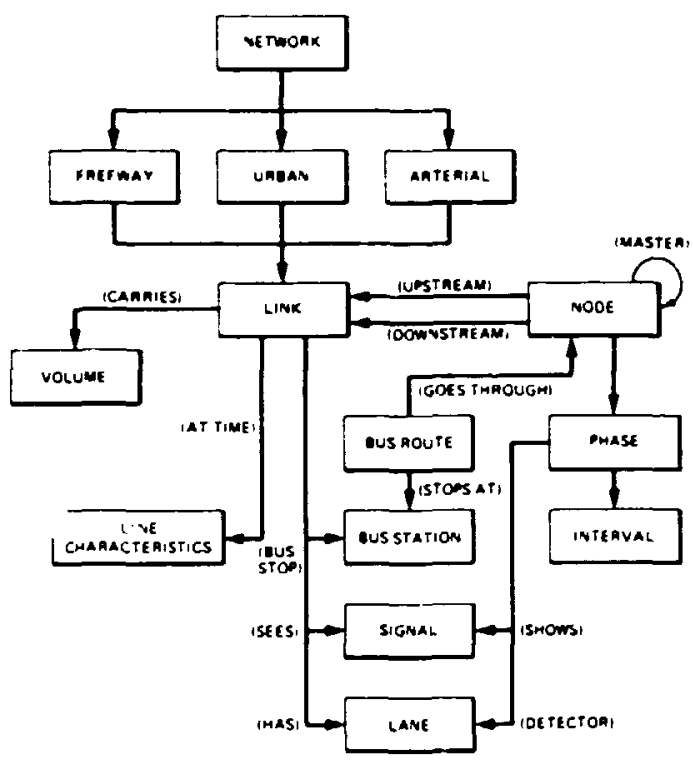

Fis. 3.5. Teatative data base schene and biterrehtionahipa.

One important design goal has been to provide a system that is not only powerful but also easy to use. This goal is being accomplished by using "menus" and screen "forms" that will be presented to the user sequentially on the microcomputer screen. This not only makes the system ensy to use, but it isolates the user from the details of the computer's operating system and programming software. Files containing help information will be accessible at all times for users who are learning the systenı or are otherwise having trouble.

The software is being written in the PASCAL language. This provides a high degree of modularity, whici simplifies maintenance, debugging, and updating of the programs. The software will also be capable; of operating on a wids range of microcomputer systems.

\subsubsection{Vehicle Teating Program}

The Vehicle Testing Program, funded by the Federal Highway Administration (FHWA), is designed to develop data-based simulators of the fuel consumption characteristics of 15 contemporary vehicles. Additionally, 6 of the vehicles are to be tested for emissions, and simulators 
for hydrocarbon and carbon monoxide emissions are to be developed. The fuel consumption and emissions simulators developed in this program will be incorporated by FHWA in their traffic network simulation programs.

The testing is carried out both on a chassis dynamometer at The University of Tennescee as well as "on-road," using a runway at the Arnold Air Force Station in Tullahoma, Teanessec. Data from the two test sets are merged to form the final simulators, which characterize fuel consumption as a function of vehicle speed and acceleration.

As of the end of the fiscal year, 10 vehicles had been tested for fuel consumption, and work had begun on the eleventh. Also, 2 of the 6 required vehicles had been tested for hydrocarbon and carbon monoxide emissions. The computer simulators and tables of fuel consumption as a function of vehicle speed and acceleration had been completed for 8 of the vehicles.

Results from the fuel consumption tests have been quite interesting and useful. The steadyspeed (zero acceleration) fuel economies for two of the cars-a Ford Escort and a Chevrolet Citation-are compared in Fig. 3.6. Note that the fuel economy of the Escort peaks at about

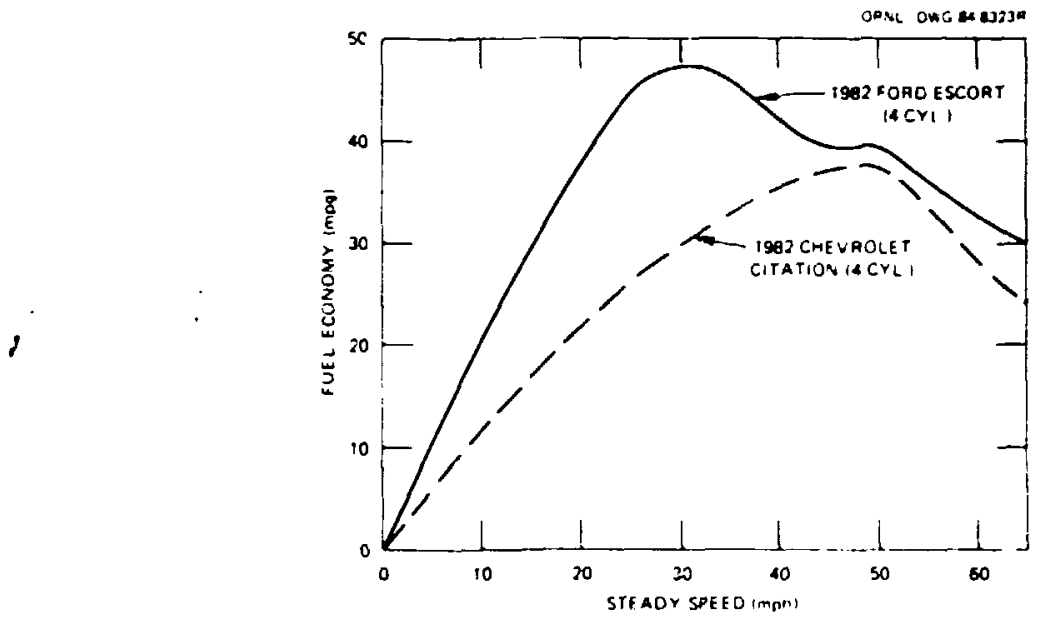

Fig. 3.6. Comparison of steady-speed fed econconies of a Ford Escort and a Cherrolet Citation.

$30 \mathrm{mph}$, which is consistent with past conventional wisdom regarding the speed at which peak fuel economy occurs. However, the Citation peaks at about $50 \mathrm{mph}$, a much better situation for maximizing the highway fuel economy. So far, our test results show about half of the cars with a peak at 30-35 mph and the other half with peaks above $40-45 \mathrm{mph}$. The fact that the figure shows a generally lower fuel economy at steady speeds for the Citation than the Escort is merely a reflection of the fact that the Citation is a bigger, heavier car. Interestingly, though, one might conclude from the figure that the highway fuel economies of the two cars might be quite close. And, indeed, the EPA estimates for the highway cycle for these two cars are $38 \mathrm{mpg}$ for the Escort and $\mathbf{4 0} \mathrm{mpg}$ for the Citation.

The fuel consumption simuiators are quite well behaved for the eight completed vehicles and compare well with other sources of information at particular points (e.g., the EPA mileage estimates). This point is supported in the accompanying Table 3.2. It should be pointed out that it 
Talk 3.2. Compribon of teat remits with EPA polvined tata

\begin{tabular}{|c|c|c|c|c|c|c|}
\hline \multirow{2}{*}{ Car } & \multicolumn{3}{|c|}{$\begin{array}{l}\text { EPA fuel conomy } \\
\text { estimates (mpg) }\end{array}$} & \multirow{2}{*}{$\begin{array}{l}\text { so-mph iruise } \\
\text { (from simulator) }\end{array}$} & \multirow{2}{*}{$\begin{array}{l}\text { Actual on-raed } \\
\text { fuel economy } \\
\text { to/from Tullahoma }\end{array}$} & \multirow{2}{*}{$\begin{array}{l}\text { 60-mph cruiso" } \\
\text { (from simulator) }\end{array}$} \\
\hline & Urban & Combined & Highway & & & \\
\hline $\begin{array}{l}1983 \text { Ford Escort } \\
98 \text { CID, } 4 \text { cyl. }\end{array}$ & 27 & 31 & 38 & 40 & 31 & 32 \\
\hline $\begin{array}{l}1982 \text { Toyola Corolla } \\
108 \text { CID, \& cyl. }\end{array}$ & 27 & 29 & 32 & 31 & 29 & 29 \\
\hline $\begin{array}{l}1982 \text { Fond Faimont } \\
140 \mathrm{CID}, 4 \mathrm{cyl} .\end{array}$ & 21 & 24 & 30 & 30 & $\begin{array}{l}\text { Insurficient } \\
\text { data }\end{array}$ & 25 \\
\hline $\begin{array}{l}1982 \text { Chev. Citation } \\
151 \mathrm{CID}, 4 \text { cyl. }\end{array}$ & 25 & 30 & 40 & 38 & 26 & 28 \\
\hline $\begin{array}{l}1983 \text { Plymouth Reliant } \\
\text { I } 56 \text { CID, \& cyl. }\end{array}$ & 24 & 26 & 30 & 30 & 24 & 26 \\
\hline $\begin{array}{l}1983 \text { Pontiac Firebird } \\
173 \mathrm{CID}, 6 \mathrm{cyl} \text {. }\end{array}$ & 20 & 25 & 34 & 33 & 26 & 32 \\
\hline $\begin{array}{l}1982 \text { Ford Futura } \\
200 \mathrm{CID}, 6 \mathrm{cyl} .\end{array}$ & 20 & 23 & 28 & 30 & $\begin{array}{l}\text { Insumiciont } \\
\text { data }\end{array}$ & 26 \\
\hline $\begin{array}{l}1983 \text { Chev. Monte Carlo } \\
229 \text { CID, } 6 \text { cyl. }\end{array}$ & 20 & 23 & 29 & 30 & 27 & 28 \\
\hline
\end{tabular}

- Approximates EPA highway driving cycle.

Approximates the way in which the cars are driven to and from Tullahoma. 
is diffrcult to find points on the simulator maps of the individual ans that might approximate either the urban or the combined EPA estimates. However, the EPA highway axtimate can be roughly approximated by a 50 -mph cruise fuel economy. Thus, the EPA's highway extimates may be compared with values frrm our simulator maps for the 50-mph steady speed. Abo, we made measures of the on-rosd fuel cocnomy both to and from Tullaboma, which provided about 320 miles of highway speed experience. If we very carefully filled the tank of the vehicte before and after the highway trips, then we obtained a value for on-roed highway trip fuel economy that should be approximated by the 60-mph steady speed value from the simulator. Table 3.2 shows that both of these comparisons are very good for the eight cars.

The most significant difference is in the on-roed highway fuet economy versw the 60-1.iph cruise fuel economy for the Pontiac Firebird. This discrepancy probably occurred because the simulator data for the 50-mph cruise is with the car in overdrive. However, in driving the car over the rather hilly terrain between Oak Ridge and Tullahoma, the car was in third gear rather than overdrive much of the time, even at $60 \mathrm{mph}$. This would tend to make the actual on-roed fued cconomy lower than the simulator value at $60 \mathrm{mph}$.

The most recent cars tested under this program have been diesel powered, and they presented new technical challenges. Whereas on the gasoline-powered cars the engine variables paramount to the testing are intake manifold pressure and engine speed, this cannot be the case for the diesel cars since there is no intake pressure variation. Therefore, as a surrogate for manifold pressure, we devised ways of measuring throttle position on the diesels, which, together with the engine speed, should uniquely define the fuel consumption.

In August 1983 the FHWA authorized two additional major tasks for the project and added six months to the project length. The new tasks are (1) the measurement of NO $\mathrm{N}_{x}$ emissions on the six cars to be tested for the other two emissions and (2) the measurement of driveshaft torque and speed for three of the vehicles. For the torque measurement task, fuel consumption will be related to the driveshaft torque and speed, and simulators developed in this way will be compared to those developed by the primary techniques of the project. The project is now scheduled for completion at the end of FY 1984.

\subsubsection{Gasoline and Diesel Fuel Forecast}

Studies of trends in motor gasoline and diesel fuel markets for EIA correctly predicted increased gasoline use in 1983, reversing an unprecedented four-year decline. If economic grownh continues, gasoline use was projected to increase at an average annual rate of $1 \%$ through 1985. The study quantified the importance of new-car fuel economy improvements, diesel market share, and vehicle usage, among other factors. An investigation of leading indicators of peak summer gasoline demand showed that spring income growth had a strong effect on the size of the summer peak. A model based on this result predicted a summer 1983 product supplied averaging $6,900,000$ bbl/day (actual product supplied was $6,907,000 \mathrm{bbl} /$ day). 


\subsection{EMERGENCY PLANNING HIGHLIGHTS}
C. V. Chester
M. V. Adler
A. M. Fullerton
D. Mileti"*
J. H. Sorensen
S. A. Carnes
K. S. Gant
J. Morell ${ }^{\text {th }}$
R. N. Thurmer
E. D. Copenhaver ${ }^{\dagger}$
D. W. Holladay"
M. Schweitzer
D. Torri-Safdie \#
G. A. Cristy ${ }^{\ddagger}$
S. J. Liebowitz'
H. B. Shapira
G. P. Zimmerman

\section{5." Hazard Mitigation Potential of EarthSheltered Resideaces}

Earth-sheltered residences have become popular in recent years for their energy conservation and environmental advantages. Those with earth-covered roofs and walls offer great inherent protection against many natural and man-made hazards, especially tornadoes, power outages in cold weather, forest fires, and radioactive fallout. United States residential construction in a single good year can produce $200,000,000 \mathrm{~m}^{2}$ of floor space. If only a few percent of this were earth sheltered, in a few years a significant addition to the nation's inventory of fallout protection could be realized. Slight modifications of the designs can enhance fallout protection at negligible cost and provide blast protecticn at moderate cost. Figure 3.7 is an example of such a design. Figure 3.8 shows the example design in its blast-hardened crisis configuration.

The principal disincentive for earth-sheltered construction is the $20 \%$ to $40 \%$ increase in cost per unit area over that of conventional frame construction. Methods to reduce this include volume production, smaller lots, use of precast units, and reusable forms. However, once the cost of building underground is accepted, the incremental cost of a blast-hardenable structure is approximately $6 \%$ over that of the "conventional" earth-sheltered structure in the example design.

In addition to cost, important institutional issues affecting the home buyer's decision to purchase an earth-sheltered residence are the structure's livability, aesthetics, and soundness of investment and the availability of suitably trained and equipped contractors and mortgage money at attractive rates.

The most promising policy options for promoting the adoption of earth-sheltered structures are education and financial incentives. Educational measures include verification of the livability and aesthetics of hazard-resistant, earth-sheltered structures and information on the existing availability of loan money and resale opportunities. A program to implement these policies might include (1) validation and dissemination of housing plans and financial information and (2) demonstration construction.

\footnotetext{
Group Leader.

'Health and Safety Research Divisiol'.

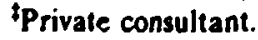

'Chemical Technology Division.

'The University of Tennessee.

"Colorado State University.

"Hahneman College.

${ }^{\text {tt} C r i s t y ~ C o n s u l t a n t s, ~ O a k ~ R i d g e . ~}$
} 

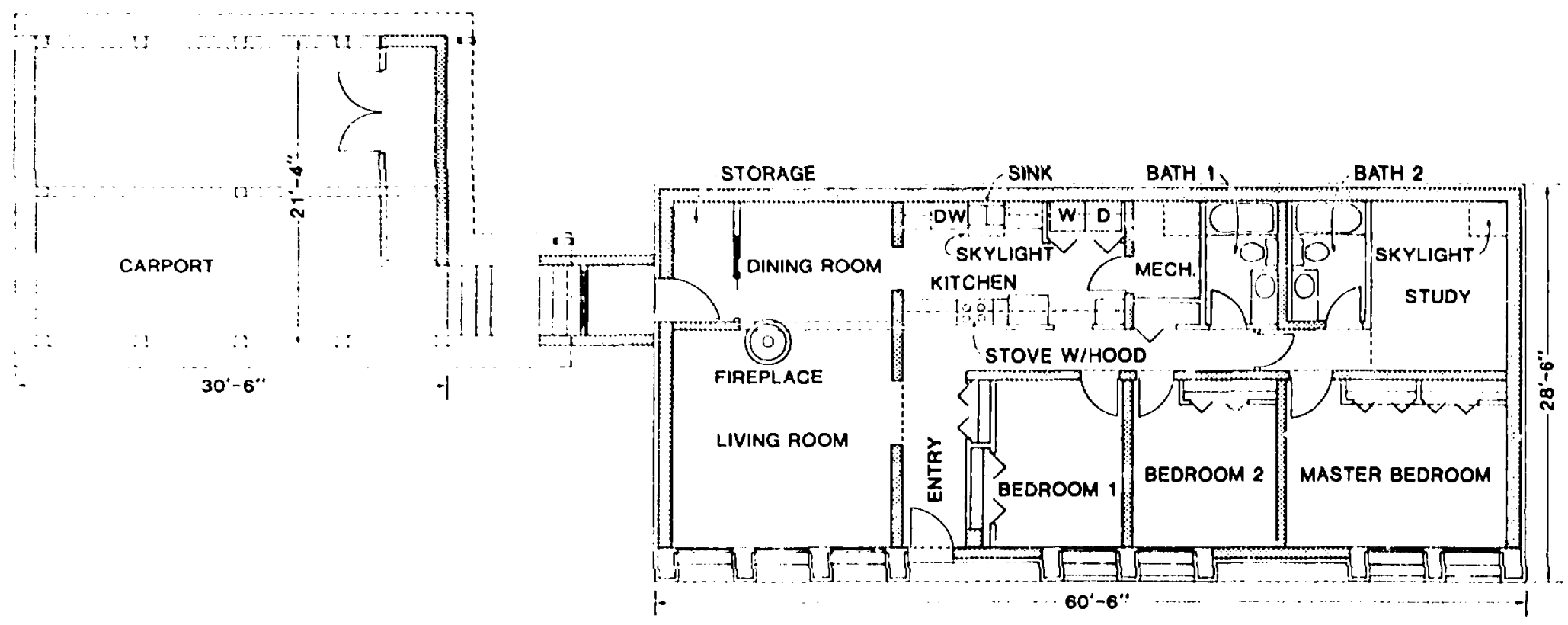

Fis. 3.7. Hazand-reabiant (crisis-tppradeable) dealga. 


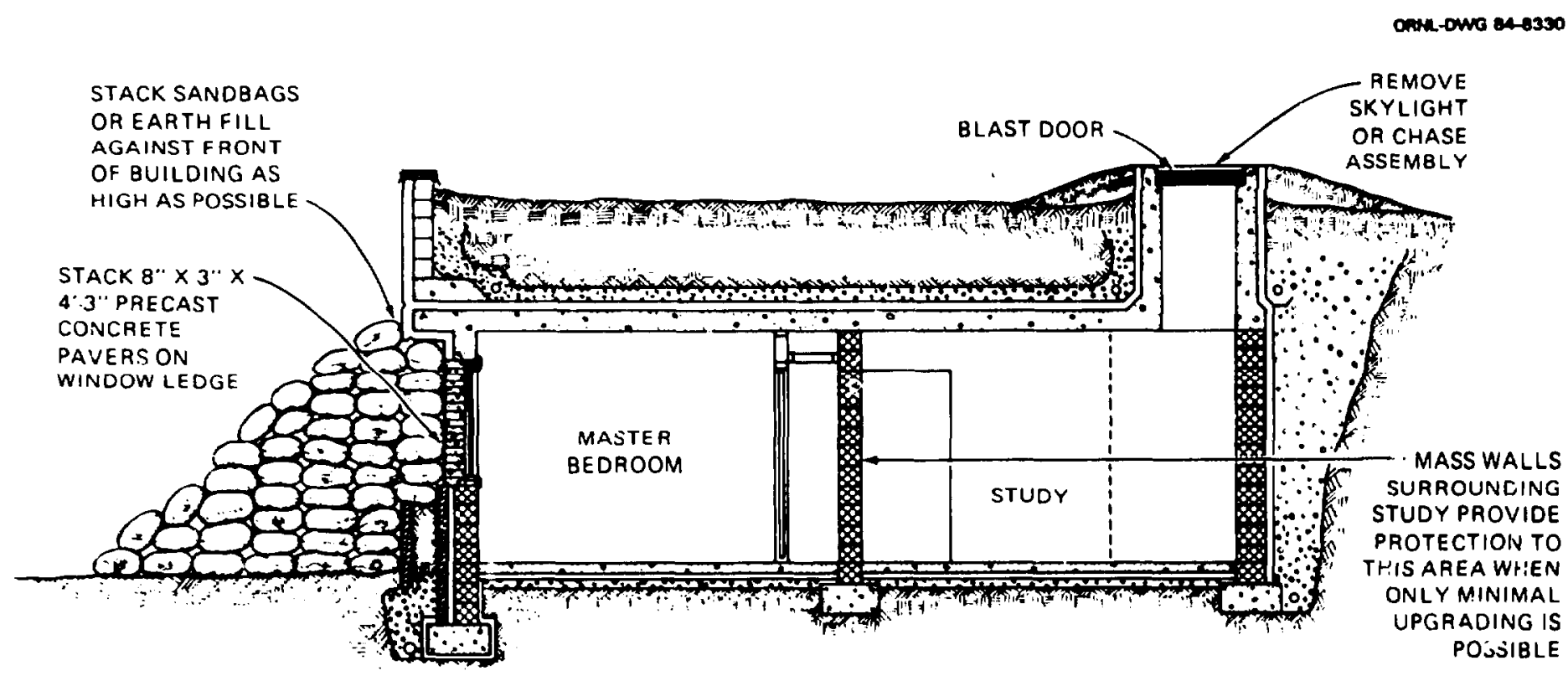

Fls. 3.8. Uproded posture. 


\subsubsection{Improved Robotic Equipneot for Radiological Emergencies}

A study has been made of the requirements for an improved mobile manipulator for use by DOE in radiological emergencies. Emergency persconel with experience in radiological emergencies were interviewed to determine the shortcomings of present equipment and features most desired in future equipment. The present technology of mobile manipulators was reviewed.

The existing DOE remotely controlled mobile manipulators are becoming somewhat dated despite modifications to them; they also have inherent scere limitations to their mobility, reliability. and ease of operation. A survey of past radiological emergencies and routine operations at DOE facilities and at two commercial power reactors, including Three Mile Island, indicates that great improvements in mobility and manipulator dexterity will be required if mobile manipulators are to be more useful in reducing radiation exposure to operating and emergency personnel. In particular, the ability to climb stairs and over air-lock thresholds is required. Bilateral forcefeedback manipulators would greatly increase the speed, reliability, and safety of manipulator operations.

In the past few years, there have been dramatic advances in manipulator technology with the development of digital control and force feodback. The development of a six-legged computercontrolled walker by the Odetic Corporation is a quantum improvement in mobility. The machine can $g 0$ almost anywhere a person can walk. Unfortunately, the Odex walker will require another $\$ 10$ million in development before it will be ready for commercial production. The cost of the first advanced-capability mobile manipulator will be between $\mathbf{S 1}$ and $\mathbf{S 2}$ million but holds the promise of removing the need for placing people in a variety of hazardous environments.

\subsubsection{Emergency Planning for Reactor Sites}

Organizational and human factor considerations in emergency planning for reactor sites continued, with support from the NRC. In the first of these two related programs, ORNL was requested to determine if existing regulations resulted in adequate interface between utilities and off-site organizations in emergency planning and response. To address this question, we attempted to assess two elements of emergency management which could be used to measure the level of interface: the comprehensiveness and cohesiveness of planning and response. The comprehensiveness of planning was determined by a detailed review of emergency plans, and the compreicisisiveness of response was determined by the evaluation of a test exercise. To assess cohesiveness, we identified, from reviewing relevant literature, a set of factors associated with cohesive response. Two case studies were used to measure the presence of these factors in planning. Second, a test exercise was observed to measure the presence of these factors in response.

The two purposes of the plan reviews were to determine whether plans would constrain a comprehensive response to an emergency and to determine if planning activities were reasonably coordinated. In general, the review of emergency plans suggested that there is adequate interface between utilities and off-site organizations in the planning process and that this interaction has lead to well-coordinated planning documents. Although this conclusion is generally correct, we also noted several areas in which interface during the planning process can be improved.

The case studies attempted to measure and assess the presence of factors that help promote cohesive response efforts botr. within and between organizations. We found that, internally, 
organizations are quite cohesive. Cohesion tends to break down, however, in relations across organizational response networks. Organizations demonstrated flexibility in their response systems, which increases the effectiveness of response.

The test exercise was used to determine if comprehensive planning led to a coordinated response and to assess how cohesiveness may change during a simulated response. Overall, we found that the observed response was not as well coordinated as the planned response. This discrepancy was mainly due to problems in implementing procedures and not from having inadequate plans and procedures. In addition, we found that internal cohesiveness increased during the exercise but that interorganizational cohesiveness decreased.

Findings suggest that implementation of existing regulations has led to comprehensive planning efforts. Minor improvements to plans can be made, but they fall within the scope of existing rules, regulations, and implementation guides. On these grounds, no regulatory changes are warranted. The findings suggest that regulations will lead to fairly comprehensive responses to an emergency. Evidence from the case studies and the test exercise suggests that problems are due to poor execution of emergency plans and lack of resources. Existing regulations explicitly deal with these problems, which can be reduced by better enforcement of regulations.

More difficult and abstract to assess is the level of cohesiveness in and between emergency organizations. Our work revealed that cohesiveness as measured in the planning process is strong within individual organizations but weaker between organizations. The difference was even more pronounced for cohesiveness in emergency response. The mi ;or reason for lack of cohesiveness was poor communications and a lack of knowledge about whom to communicate with. This problem is intensified by a lack of legitimacy among organizations; that is, some organizations do not have confidence in others or do not believe they play an important role.

Overall, our research suggests that the problems experienced at Three Mile Island with response to planning and coordination will not occur in another emergency unless existing regulations are not followed or if existing plans are not properly implemented. Mechanisms for ensuring that plans are properly implemented are, however, part of the existing regulations.

In the second related program sponsored by the NRC, ORNL was requested to determine the role human factors play in emergency classification and off-site notification. The findings suggest that human or nontechnical factors play a role in the classification procedure. Four major categories of factors are identified and discussed: the classification system, stress, organizational structures, and interpersonal relationships. These factors were identified through discussions with utility personnel, a case study of the Ginna Site Emergency, and experiments with operators. The main conclusion is that a change in the classification system will eliminate many of the problems. In addition, other specific actions can be used to seduce the potential effects of human factors on classification vecisions. The research showed that notification of off-site officials is not highly susceptible to human problems and that it is not a significant factor in the classification decision.

\subsection{RESEARCH UTILIZATION}

The RUS Section engaged in several research utilization activities in FY 1983. A continuing workshr $p$ series was organized and presented to state and regional energy officials to provide them with a ailable techniques and approaches developed at ORNL or elsewhere to evaluate the effectiv sness of state energy conservation programs. 


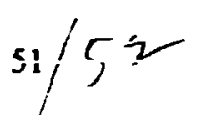

A major program in international technology transfer was undertaken; it involved working closely with government officials in Liberia to transfer and use an integrated assessment approach to analyze the future energy options for this West African nation. In another international effort, our staff assisted the Government of Tunisia in developing an improved system for collecting and analyzing data on transportation encrgy use in that country. Domestically, our resource analysis team conducted a workshop to transfer a wilderness trade-off methodology developed by ORNL to geologists making uranium assessments in the West.

Toward the end of the year, we began a major research utilization task for the BTESIM Program and became actively involved in transferring technical results from the buildings research program to the architectural and building community through workshops, conferences, and classroom instruction.

\subsection{REFERENCES}

I. N. E. Collins, J. H. Reed, and R. B. Braid, A Systematic Review of Approaches to Assessing Energy Conservation Program (SECP and EES) Impacts, ORNL/TM-8771, Oak Ridge National Laboratory, July 1983.

2. E. Peelle, R. B. Braid, D. W. Jones, and J. H. Reed, Reaching People with Energy Conservation Information: Four Statewide Residential Case Studies, ORNL-5984, Oak Ridge National Laboratory, September 1983.

3. M. Schweitzer and S. A. Carnes, Local Government Programs to Sove Energy: Case Studies of Four Selected Communities, ORNL-5982, Oak Ridge National Laboratory, September 1983.

4. L. N. McCold, N. E. Collins, P. B. Zuschneid, and R. B. Hofstra, Thermal Efficiency Standards and Codes: Vol. 2-Relationships of ASHRAE Standards and External Factors to Energy Efficient Building Practices in New Homes, ORNL/CON-101/V2, Oak Ridge National Laboratory, February 1984.

5. J. H. Sorensen, E. J. Soderstrom, R. Rolin, E. D. Copenhaver, and S. A. Carnes, Restarting TMI Unit One: Social and Psychological Impacts, ORNL-5891, Oak Ridge National Laboratory, December $198 \mathrm{~J}$.

6. M. G. Rorke, L. M. Bronfman, and E. J. Soderstrom, Evaluation of the Energy-Related Inventions Program. Volume I: Analysis of Case Studies of Supported Projects, ORNL/CON-92/VI, Oak Ridge National Laboratory, February 1983.

7. E. J. Soderstrom, L. M. Bronfman, and M. L. Rorke, The Energy-Related Inventions Program, An Overview of the Evaluation, ORNL/CON-92/V3, Oak Ridge National Laboratory, September 1983.

8. 198.3 Annual Energy Outlook. Energy Information Administration, Office of Energy Markets and End Use, U.S. Department of Energy (to be published).

9. James L. Sweeney, -U.S. Gasoline Demand: An Economic Analysis of the New EPCA New Car Efficiency Standard," Advances in the Economics of Entrgy and Resources, Volume 1: The Structure of Energy Markets, Robert Pindyck (ed.), JAI Press, Greenwich, Conn., 1978.

10. G. Kouris, "Fuel Consumption for Road Transport in the U.S.A.," Energy Economics, pp. 89-99 (April 1983).

11. The Highway Fuel Consumption Model-Ninth Quarterly Report, Energy and Environmental Analysis, Inc., Arlington, Va., Feb. 25, 1983. 


\title{
4. Economic Analysis Section
}

\author{
R. B. Shelton
}

\subsection{INTRODUCTION}

The Economic Analysis Section is the disciplinary home for economists at Oak Ridge National Laboratory (ORNL). The section's major objectives are to further the knowledge of energy economics and to apply this knowledge to research issues throughout ORNL. As a resu!t of this latter objective, many of the section's research projects are located in other sections in the Energy Division and in other ORNL divisions. Although the economists often work in multidisciplinary teams on projects in other divisions, their central location and coordinated professional activities, such as seminars, allow them to develop and exchange new economic concepts.

Administsatively, the section is divided into two groups and two program areas. The two groups are the Energy and Technology Group and the Resource and Environmental Analysis Group, and the programs are the Energy Demand Analysis and Uranium Industry Analysis programs.

\subsubsection{Energy and Technology Group}

\section{J. Bjornstad}
T. R. Curlee
R. C. Tepel
L. J. Hill
D. A. Trumble
C. R. Kerley
J. W. Van Dyke

The Energy and Technology Group conducts economic analyses that fall into three topical areas: (1) model-related analysis, (2) regulatory analysis, and (3) technology-related analysis. Because of the section's applied orientation and broad interests, these areas are intended to form a basis for organizing research in ways to complement other activities in the section rather than to define a hard-and-fast line for group responsibilities. Group staff members work jointly on a number of projects, both with other economists and other Laboratory staff members, as their particular skills and experience are required.

Model-related activities in the Energy and Technology Group are supported primarily by the Energy Information Administration (EIA) of the U.S. Department of Energy (DOE). Currently,

\footnotetext{
Group Leader.
} 
this work includes the evaluation and documentation of EIA models, as well as advising EIA on changes and improvements to its modeling capability. For example, recent activities have been focused on evaluating the ElA electric supply model. For this evaluation, the staff is developing a variety of recommendations for improvements. The staff also assists EIA staff in the selection and development of quantitative metlods for their modeling efforts. For example, if EIA needs to reconcile various forecasts produced by differert models, the staff may prepare a background paper to assist in choosing a method to accomplish this.

The group has conducted a large number of regulatory studies during the past year, some jointly with other section staff members. A study of the need for breeder reactor power (see Sect. 4.2.1) is an excellent example of such a joint effort. Examples of other regulatory studies include a comprehensive analysis of electric power wheeling, which was recently completed, and an analysis of differences in the financial and regulatory treatment given investor-owned utilities, municipaland state-owned utilities, Rural Electrification Administration-funded co-ops, and federal power projects. In addition, the group participates in the preparation of environmental impact statements and conducts work in their support ${ }^{1}$ on a regular basis. During the past year, the group also completed regulatory impact analyses for the Commercial and Apartment Conservation Service and the Residential Conservation Service. ${ }^{2}$

Although at present the study of tecnnological change occupies only modest amounts of staff effort, we view this area as having the potential for substantial growth. Currently, staff members are working with the ORNL Metals and Ceramics Division on the study of plastics recycling and market penetration of new materials. In addition, the staff is pursuing support in the areas of technology transfer and the economics of information. Regarding technology transfer, we are currently assisting the Bonneville Power Administration by preparing computer programs that permit them io apply state-of-the art methods of time series analysis to the projection of short-term electricity demand.

\subsubsection{Resource and Environmental Analysis Group}

$$
\text { D. P. Vogt" }
$$
R. A. Cantor
R. D. Perlack
S. M. Cohn
C. G. Rizy
D. M. Hamblin ${ }^{\dagger}$
A. F. Turhollow, Jr.

The primary objective of the Resource and Environmental Analysis (R\&EA) Group is to provide the bridge between the theoretical framework of economic choice and the technological and environmental evaluations of alternative energy demand and supply strategies conducted at ORNL. Investments in alternative energy supply options are frequently formulated in terms of specific technological choices. However, energy supply decisions frequently involve environmental externalities on human health, safety, and amenities. In addition, specific technological approaches often ignore the induced impacts on other segments of the economic system, and, unless such externalities and indirect impacts are internalized into the economic evaluation, nonoptimal recommendations may result.

\footnotetext{
-Group Leader.

'Orf-site assignment.
} 
During the past year, R\&EA Group members have been primarily involved with research in four program areas: (1) biomass energy technologies, (2) environmental assessments, (3) evaluations of energy facility investment and use, and (4) energy demand analysis. Activities of R\&EA Group members for the fourth area are discussed in Sect. 4.1.3. Most of the program activities of the R\&EA staff involve contributions to integrated, multidisciplinary activities.

Economists from the R\&EA staff are providing economic analysis support in biomass research to the Environmental Sciences Division in three areas: (1) the multiyear program planning efforts for the Biomass Energy Technology Division of DOE, (2) the short-rotation woody crops program, and (3) the herbaceous energy crops program. The program planning effort and the herbaceous energy crops program are relatively new activities for the R\&EA Group. Recent activities on the short-rotation woody crops program are described in Sect. 4.2.2. In addition to these areas, some research has been completed on the long-run impacts of increased biomass use. ${ }^{3}$

The R\&EA staff also supports DOE's Office of Environmental Assessment (OEA) in a joint effort with the Integrated Assessments Group (see Sect. 2.1.4). The R\&EA Group provides contract management support and technical oversight for research activities that ORNL and its subcontractors conduct for OEA. Environmental assesssment activities are in three major areas:

1. standby expertise of ORNL analysts to aid OEA in preparing position statements on issues involving the interaction of energy policy decisions and environmental impacts;

2. applied research to aid OEA in identifying emerging issues and to develop data, models, and analysis that will provide OEA with appropriate analysis capability; and

3. the maintenance of a diverse set of models and data bases in support of OEA analysis efforts.

During FY 1983 the R\&EA Group began an examination of alternative frameworks to provide regional projections of economic activity in a cost-effective manner based on the standard OBERS procedure. The implementation of a simplified model is expected to begin in FY 1984. OEA has also supported ORNL in developing and maintaining a variety of data bases relating to the location of key energy-using manufacturing facilities. This activity is expected to expand in FY 1984, with an examination of the spatial shifts in manufacturing activities which have occurred between the 1975 base year of current OEA industrial files and 1980.

Research in the area of energy facility investment and use is characterized by the headwater benefits project (see Sect. 4.2.6) and the nuclear plant investment study. The nuclear plant investment project for DOE/EIA, which started this year, is an investigation of the factors determining the divergence between engineering cost estimates and costs actually experienced by purchasing utilities. Most of the prior research on nuclear plant investment costs has been focused on explaining the determinants of the actual costs of plant construction. The focus of the R\&EA research is on the determinants of the difference between the initial investment cost estimates and final costs. An understanding of these factors would improve current and future investment decisions regarding alternative energy supply technologies. The first phase of the research was the establishment of the required analytical data base. The R\&EA staff has constructed a data file that includes information for the 51 nuclear power plants constructed between January 1966 and April 1981, using as a primary source the information from DOE/EIA Form EIA-254. The second phase of the research will be completed in FY 1984.

A preliminary examination of the data base confirms the divergence of the initial engineering cost and the final construction cost and indeed indicates that the divergence appears to have been 
increasing during the period examined. In Fig. 4.1, the ratio of the final estimated cost (representative of the actual final cost) per kilowatt of net operating capacity to the initial cost estimate is plotted for the 51 plints according to the date of initial construction. Figure 4.1 shows that the ratio is rising over time. If this rise is substantiated in further analysis, the question of why "learning by doing" did not take place in the nuclear power industry could form the basis for furtber research.

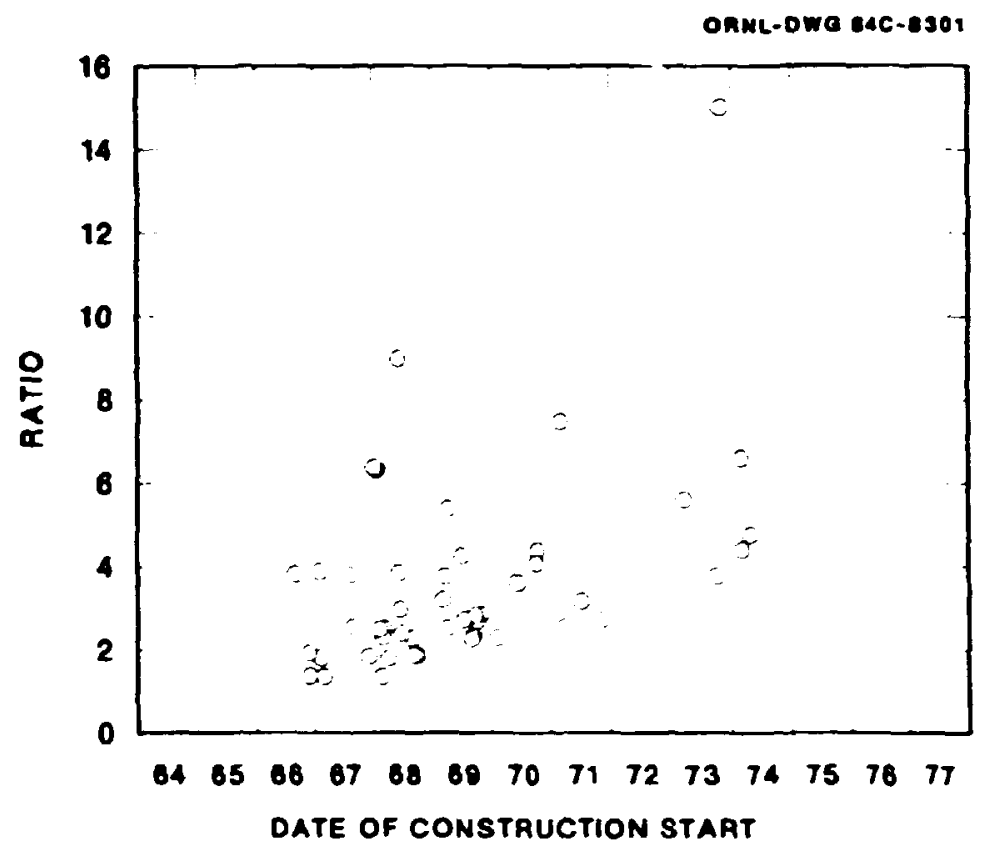

Fig. 4.1. Ratio of the fial cost estimate per kilomate (electrical) to the

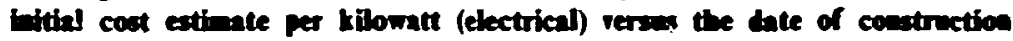
start for melear power plants.

\subsubsection{Energy Demand Modeling Program}

D. M. Hamblin

Activities of the energy demand modeling program have been focused in two major areas (1) the development of economic/engineering end-use models and (2) econometric models of electricity demand. The Economic Analysis Section has extended the residential and commercial end-use models, initially developed at ORNL by Eric Hirst. Although significant improvements to the carlier models have been made, additional development work, based on findings discussed in Sect. 4.2.7, is envisioned.

\footnotetext{
"Program Leader.
} 
The major use of the end-use models has been the evaluation of energy conservation initiatives. These analyses would be enhanced by development of a better structure for depicting the programmatic conservation impacts, including market distortion impacts, as well as incorporating expectations of future market prices. Additionally, efforts to improve the market segment approach will continue in order to minimize potential aggregation bias in the current model versions. Cemmercial model developments would include a proper definition of heating, ventilating, and airconditioning (HVAC) systems and incorporating a nested logit fuel choice estimation.

Potential areas of development in the econometric energy demand modeling are the simplifying of the structure of the Rural Electricity Demand (REED) Model and the expansion of the econometric demand modeling efforts to include all fuels. In both cases, interest has also been expressed in developing simulation models that could operate on small personal computer systems. This development would increase the potential number of users and encourage model transfer activities.

\title{
4.1.4 Uranium Industry Analysis Program
}

\author{
R. B. Shelton" \\ R. Lee + t \\ G. A. Dailey $*$ t"
}

The uranium industry program is focused on a multiyear study of the viability of the domestic uranium industry. Public Law 97-415 specifies that the President shall submit to Congress a comprehensive review of the status of the domestic uranium mining and milling industry. Also, the law directs the Secretary of Energy to monitor and report annually to the Congress on the viability of the domestic industry for the years 1983 to 1992. ORNL is assisting EIA in the presidential review as well as in the annual assessment of the industry's viability.

This project has two general objectives: (1) to assist EIA in producing the first two reports (DOE's and the President's) and (2) to establish a framework for the annual DOE review and report to Congress of the domestic uranium industry. The project has been underway since July 1983, and ORNL efforts have been concentrated on gathering appropriate data for assessing the world uranium supply and demand ilarket; assessing a large international uranium supply and demand model (the International EUREKA Model); and assisting the EIA in preparing, conducting, and evaluating three public hearings to heip identify criteria by which the public might wish to have the riability of the domestic uranium industry evaluated. The public hearings have been completed, and a review and prioritization of public commerts is underway, which will lead to rule-making by DOE on the criteria to be used. Public Law 97-415 contains evaluation criteria, and public comments were secured to determine if the criteria should be revised, deleted, or expanded or if niw criteria were needed in addition to those currently in the law.

\footnotetext{
'Project Manager.

'Regional and Urban Studies Section, Energy Division.

'Data and Analysis Section, Energy Division.
} 


\subsection{TECHNICAL HIGHLIGHTS}

\subsubsection{Clinch Rirar Breeder Reactor: An Assessement of Need for Power and Regulatory Issues}

\section{M. Hamblin"}

This project was designed to assist DOE in (a) reviewing the "need for power" from the Clinch River Breeder Reactor (CRBR) in the Southeastern Electric Reliability Council (SERC) region, not including Florida, and (b) isolating specific regulatory and institutional issues and physical transmission capacities that may constrain the market for CRBR power. A comprehensive needfor-power assessment was undertaken for the region shown in Fig. 4.2 subsequent to a preliminary

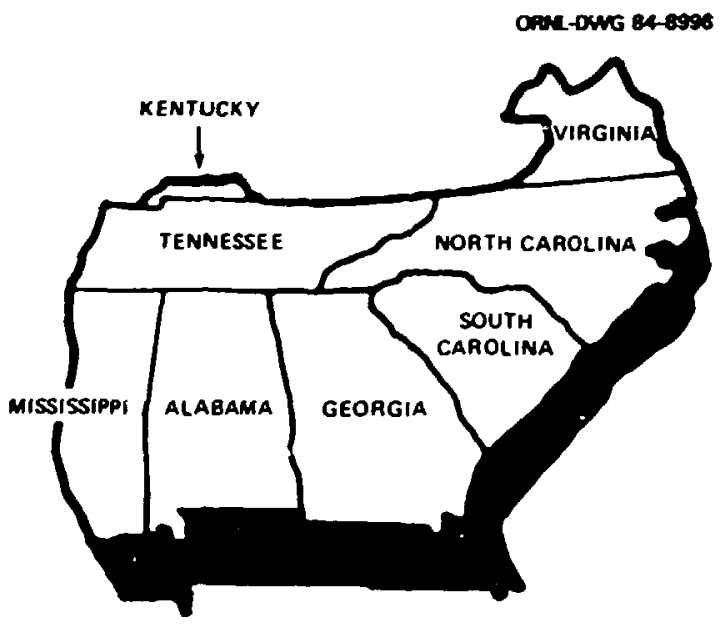

Fig. 4.2. SERC region (mines Florida).

analysis of CRBR market potential for a broad service area including Florida, Kentucky, Illinois, Indiena, Ohio, Texas, Lovisiana, and Arkansas. A review of existing electric power wheeling arrangements in the Southeast and of specific federal and state reguiatory obstacles that could affect power sales from the CRBR was also undertaken. This review was a contributing factor to a decision to target the service territory to the SERC region minus Florida. The following are the principal findings of the review:

- Substantial power interchanges occur in the region, and transmission capabilities probably will not constrain sales from the CRBR, although constraints do exist for Florida and Texas.

- If power from the CRBR could be sold to the utilities at less than or equal to the avoided cost of those utilities, the regulators of those utilities will probably not object to the sale.

- The Tennessee Valley Authority (TVA) has postponed or cancelled a number of generating

'Fourteen persons participated in this effort. Principal authors of the project report were Hamblin, R. C. Tepel, D. J. Bjornstad, and L. J. Hill. 
units, but these actions could reflect legal constraints on the sale of TVA power outside its service area rather than a lack of a market outside its service area.

- Although transmission facilities and the regulatory climate are favorable for sales from the CRBR, a number of constraints could be encountered.

- Utilities within the region with excess capacity coming on-line have been aggressively marketing shares in new plants.

- The perception of excess capacity in the area by state regulators might cause them to reject any investment by utilities in new facilities.

In general, the need-for-power analysis revealed that by 1995 a capacity shortage in the SERC (minus Florida) region will provide a market for power from the CRBR, although it should be recognized that the CRBR is a relatively small power source when compared to the SERC (minus Florida) power grid.

This general conelueion rests upon the following, more specific findings:

- An appropriate reserve margin for the SERC (minus Florida) region-where the reserve margin is defined analytically as a function of the anticipated 1990 s generating mix-is $23 \%$.

- The 1990 s reserve margins for SERC (minus Florida) subregions are as follows:

Southern Companies-23-24\%:

TVA-21\%

Virginia, Carolinas--24\%

- Committed capacity-defined as existing plants minus planned retirements and those under construction (not including nuclear plants less than 10\% complete)-for the SERC (minus Florida) region is anticipated to be $115,028 \mathrm{MW}$ in 1990 and $115,521 \mathrm{MW}$ in 1995 and 2000. Planned capacity-defined to include existing plants minus planned retirements, plants under construction, and planned capacity additions-is anticipated to be $116,600 \mathrm{MW}$ in 1990 , $120,181 \mathrm{MW}$ in 1995 , and $120,781 \mathrm{MW}$ in 2000 .

- SERC (minus Florida) peak demand projections indicate the existence of significant capacity shortfalls by 1995. These results are summarized in Table 4.1. The low, medium, and high world oil price scenarios depicted are designed to be consistent with scenarios depicted by DOE/EIA and described in the 1982 Annual Report to Congress.' Under the southern regional growth scenario, the SERC (minus Florida) region is presumed to attain an average per-capita income equal to the nation's average per-capita income by 2020.

- The CRBR power of $350 \mathrm{MW}$ is a small percentage of the projected capacity shortfalls. Table 4.2 lists these percentages calculated relative to both committed and planned capacity. On the basis of the Table 4.1 forecasts, the CRBR could suffice to supply from $3 \%$ to $9 \%$ of the projected committed capacity shortfall in 1995 and from $1 \%$ to $2 \%$ of the committed capacity shortfall in the year 2000 .

- It is believed that year 2000 committed and planned capacity relative to peak demand projections indicates the absence of cursent utility planning for year 2000 capacity additions. On the other hand, committed and planned capacity figures probably include existinz capacity which will be retired in the 1990s but which is not so listed in capacity planning information provided to the SERC. 


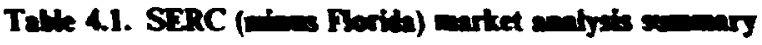
(neopinats)

\begin{tabular}{|c|c|c|c|}
\hline $\begin{array}{l}\text { Peat demand projections and } \\
\text { impliod capecity shortfalf }\end{array}$ & 1990 & 1995 & 2000 \\
\hline Committed capacity & 115,028 & 115,521 & 115,521 \\
\hline $\begin{array}{l}\text { Capability with 23\% } \\
\text { reserve margir }\end{array}$ & 93,683 & 94,101 & 94,101 \\
\hline Planned capacity & 116,600 & 120,181 & 120,781 \\
\hline $\begin{array}{l}\text { Capability with } 23 \% \\
\text { reserve margin }\end{array}$ & 94,962 & 97,777 & 98,247 \\
\hline $\begin{array}{l}\text { End use-low world oil price } \\
\text { Shortfall in committed capacity } \\
\text { Shortfall in planned capecity }\end{array}$ & $\begin{array}{r}85,305 \\
\text { None } \\
\text { None }\end{array}$ & $\begin{array}{r}97,257 \\
4,105 \\
\text { None }\end{array}$ & $\begin{array}{r}110,480 \\
20,369 \\
15,109\end{array}$ \\
\hline $\begin{array}{l}\text { End use-medium world oil price } \\
\text { Shortfall in committed capacity } \\
\text { Shortfall in planned capacity }\end{array}$ & $\begin{array}{r}88,432 \\
\text { None } \\
\text { Noace }\end{array}$ & $\begin{array}{r}101,458 \\
9,272 \\
4,612\end{array}$ & $\begin{array}{r}114,844 \\
25,737 \\
20,477\end{array}$ \\
\hline $\begin{array}{l}\text { End use-high world oil price } \\
\text { Shortfall in committed capacity } \\
\text { Shortfall in planned capacity }\end{array}$ & $\begin{array}{r}90,998 \\
\text { None } \\
\text { None }\end{array}$ & $\begin{array}{r}103,418 \\
11,683 \\
7,023\end{array}$ & $\begin{array}{r}115,917 \\
27,057 \\
21,797\end{array}$ \\
\hline $\begin{array}{l}\text { End use-southern regional growth } \\
\text { Shortall in committed capecity } \\
\text { Shortfall in planned capacity }\end{array}$ & $\begin{array}{r}90,829 \\
\text { None } \\
\text { None }\end{array}$ & $\begin{array}{r}105,251 \\
13,938 \\
9,278\end{array}$ & $\begin{array}{r}119,739 \\
31,758 \\
26,498\end{array}$ \\
\hline $\begin{array}{l}\text { SLED-medium world oil price } \\
\text { Shortfall in committed capacity } \\
\text { Shortfall in planned capacity }\end{array}$ & $\begin{array}{r}107,600 \\
17,320 \\
15,748\end{array}$ & $\begin{array}{r}129,897 \\
44,252 \\
39,592\end{array}$ & $\begin{array}{r}155,263 \\
75,452 \\
70,192\end{array}$ \\
\hline $\begin{array}{l}\text { SLED_southern regional growth } \\
\text { Shortfall in committed capacity } \\
\text { Shortfall in planned capacity }\end{array}$ & $\begin{array}{r}110,892 \\
21,369 \\
19,797\end{array}$ & $\begin{array}{r}136,546 \\
52,431 \\
47,771\end{array}$ & $\begin{array}{r}163,140 \\
85,141 \\
79,881\end{array}$ \\
\hline $\begin{array}{l}\text { Revised SERC projections for SERC } \\
\text { minus Floridabs }\end{array}$ & 89,303 & 102,483 & 118,991 \\
\hline $\begin{array}{l}\text { Shortfall in committed capacity } \\
\text { Shortiail in planned capacity }\end{array}$ & $\begin{array}{l}\text { None } \\
\text { None }\end{array}$ & $\begin{array}{l}8,694 \\
4,034\end{array}$ & $\begin{array}{l}28,999 \\
23,739\end{array}$ \\
\hline
\end{tabular}

and Use" projections are prepared using the ORNL End-Use Energy Demand Modeling System. -SLED" projections are prepared by using the State-Level Electricity Demand Model. Planned capacity refers to existing plants minus anticipated retirements, plants under construction, and planned additions. Committed cafacity excludes units not yet begun and nuclear units lew than 105 complete. Shortfalls are calculated by multiplying the peak demand projection by 1.23 to acosunt for needed reserve margins and subtracting committod and planned capacity totals, as appropriate.

'According to May 20. 1983, letter from William R. Browntee (SERC) to William F. Rolf (Project Management Corporation).

For these projections only, SERC (minus Florida) includes Southern Companies' Gulf Power Company, which serves the Florida Panhandle. 
Talle 4.2. CRBR power as a percentage of capactity shactials

\begin{tabular}{|c|c|c|c|c|c|}
\hline Modele & Scenario & Capacity & 1990 & 1995 & 2000 \\
\hline \multirow[t]{4}{*}{ End use } & Low world oil price & $\begin{array}{l}\text { Committed } \\
\text { Planned }\end{array}$ & $\begin{array}{l}\text { NA' } \\
\text { NA }\end{array}$ & $\begin{array}{l}8.53 \\
\text { NA }\end{array}$ & $\begin{array}{l}1.72 \\
2.32\end{array}$ \\
\hline & Modium world oil price & $\begin{array}{l}\text { Committed } \\
\text { Planned }\end{array}$ & $\begin{array}{l}\text { NA } \\
\text { NA }\end{array}$ & $\begin{array}{l}3.77 \\
7.59\end{array}$ & $\begin{array}{l}1.36 \\
1.71\end{array}$ \\
\hline & High workd oil price & $\begin{array}{l}\text { Committed } \\
\text { Planned }\end{array}$ & $\begin{array}{l}\text { NA } \\
\text { NA }\end{array}$ & $\begin{array}{l}3.00 \\
4.98\end{array}$ & $\begin{array}{l}1.29 \\
1.61\end{array}$ \\
\hline & Southern regional growth & $\begin{array}{l}\text { Committed } \\
\text { Planned }\end{array}$ & $\begin{array}{l}\text { NA } \\
\text { NA }\end{array}$ & $\begin{array}{l}2.51 \\
3.77\end{array}$ & $\begin{array}{l}1.10 \\
1.32\end{array}$ \\
\hline \multirow[t]{2}{*}{$\begin{array}{l}\text { Econometric } \\
\text { (SLED) }\end{array}$} & Medium world oil price & $\begin{array}{l}\text { Committed } \\
\text { Planned }\end{array}$ & $\begin{array}{l}2.02 \\
2.22\end{array}$ & $\begin{array}{l}0.79 \\
0.88\end{array}$ & $\begin{array}{l}0.46 \\
0.50\end{array}$ \\
\hline & Southern regional growth & $\begin{array}{l}\text { Commitied } \\
\text { Planned }\end{array}$ & $\begin{array}{l}1.64 \\
1.77\end{array}$ & $\begin{array}{l}0.67 \\
0.73\end{array}$ & $\begin{array}{l}0.41 \\
0.44\end{array}$ \\
\hline Revised SERC & & $\begin{array}{l}\text { Committed } \\
\text { Planned }\end{array}$ & $\begin{array}{l}\text { NA } \\
\text { NA }\end{array}$ & $\begin{array}{l}4.03 \\
8.68\end{array}$ & $\begin{array}{l}1.21 \\
1.47\end{array}$ \\
\hline
\end{tabular}

"End-use" Model refers to ORNL End-Use Energy Demand Modeling System. "SLED" Model refers to the State-Level Electricity Demand Model.

"NA signifies "not applicable" because the predicted capability exceeds the projected peak demand.

\title{
4.2.2 Short-Rotation Woody Crops Program
}

\author{
R. D. Perlack
}

The objective of the economic analysis efforts in support of the Short-Rotation Woody Crops Program is to determine ways to increase the economic efficiency of producing woody energy feeulstocks using short-rotation intensive culture (SRIC). To derıonstrate how biomass productivity, selling prices of biomass fuels, discount rates, and management costs affect the economics of SRIC, two different biomass systems were examined. Staff members of the Energy and Environmental Sciences divisions examined the production of biomass fuels from mesquite (prosopis spp.) and hybrid poplar (populus spp.), since they represent diverse system designs. Mesquite plantations would be representative of semiarid regions, while hybrid poplar would be located in moist, temperate zones. Overall, the establishment and cultural management activities are much more intense and more costly for the hybrid poplar than for mesquite. Concomitantly, productivity is higher with the hybrid poplar. Since the approach used is similar for both species, only the results developed for hybrid poplar will be discussed in detail.

The initial decision on the spacing of hybrid poplar limits the number of feasible rotation ages (i.e., the period between harvests) which need to be evaluated in the economic framework. In general, for any given species, denser spacings will dictate shorter rotation periods, and wider spacings will require somewhat longer cutting cycles. Within this range of feasible cutting cycles, the optimal rotation age will be the one that maximizes the net present value of the biomass plantation and will be determined by the discount rate, cultural management, and harvesting costs as well as the selling price of biomass fuels. 
The FIRSTCUT Model was used to determine the optimal rotation age and to explore the sensitivity of the rotation age to changes in various model parameters for hybrid poplar SRIC plantation design of 4,500 ha. ${ }^{6}$ For a selling price of $\$ 2.35$ per gigajoule of biomass fuel, the optimal rotation cycle ivas five years for all discount rates. At a selling price of $\mathbf{\$ 2 . 0 6}$ per gigajoule, the optimal rotation age was six years for lower discount rates and five years for higher discount rates. These results, although based on very preliminary data, tend to confirm that the optimal rotation age is shortened by increases in selling price and by higher discount rates. Clearly, increases in the selling price increase the value and consequently the carrying costs of the standing biomass, indicating the attractiveness of a shorter rotation age. The net present value of a hypothetical hybrid poplar plantation as a function of the real discount rate for three rotation ages and three selling prices of biomass fuel is illustrated in Fig. 4.3.

Further sensitivity analysis of other factors that could affect the optimal rotation age was then conducted. Variations in biomass productivity are similar to the effects of variation in selling price

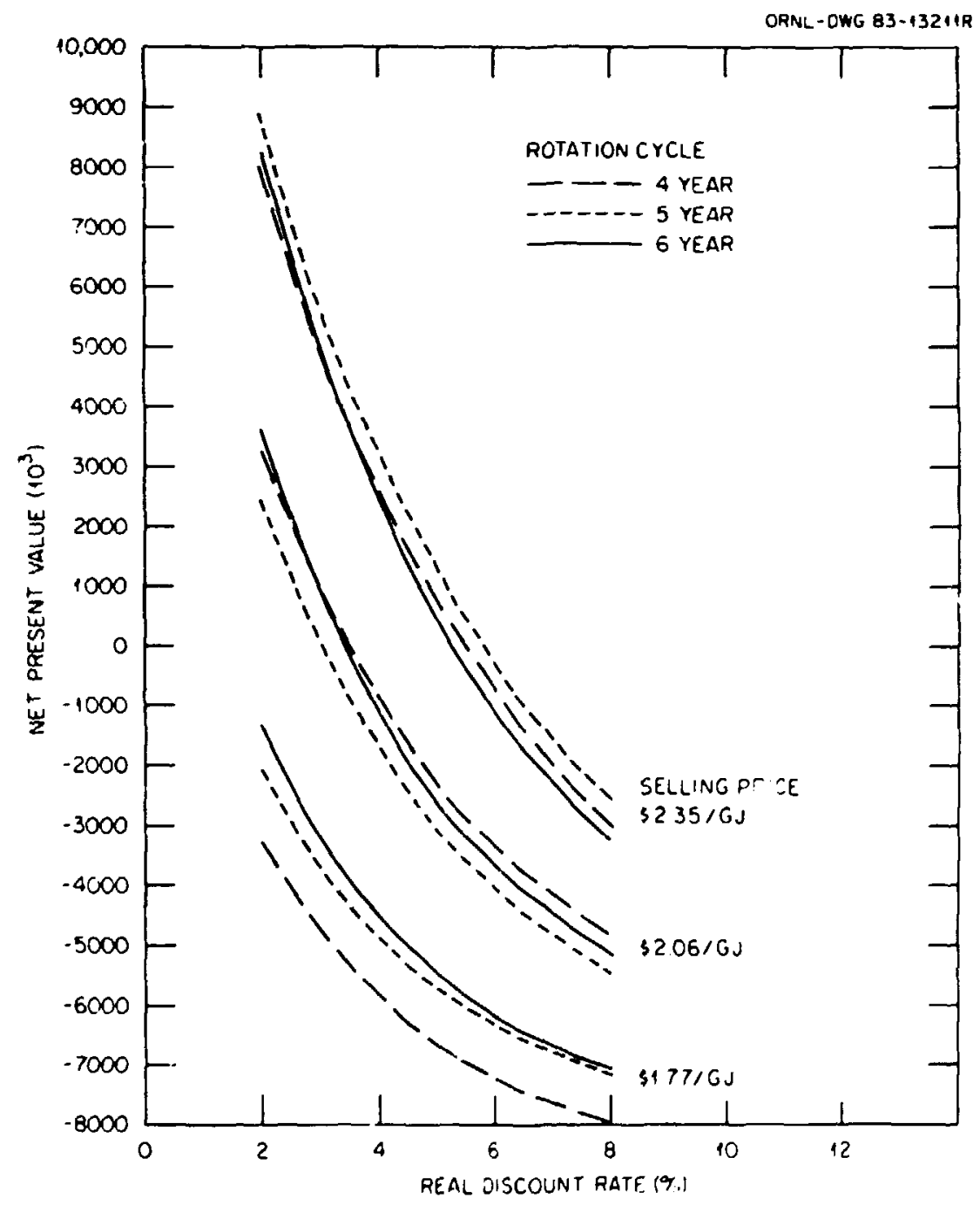

Fig. 4.3. Vartation in act present value of a bybrid puplar piantation with ef anges in price and rotation age. 
on the optimal rotation age ano the net present value. A decrease in the yield of hybrid poplar from the plantation tended to lengthen the optimal rotation age. As a rule, higher yields will tend to shorten the rotation length, especially with higher discount rates. Relatedly, an important consideration in the economics of $u$ zody biomass plantations is the number of coppice harvests that are attainable. Coppice harvests are those which result from a resprouting after the initiai harvest. The optimal rotation age for hybrid poplar was found to be sensitive to the number of coppices. An ir crease in the number of coppices shortened the rotation age, especially at higher discount rates.

The optimal rotation age of the hypothetical hybrid poplar example was not sensitive to a moderate variation in the cost of the major plantation production activities of establishment, cultural management, and harvesting. To be sure, substantial increases (decreases) in any of the cost activities would tend to lengthen (shorten) 'he rotation age, provided there are no related charges in productivity.

A summary of the preliminary sensitivity analysis is presented in Table 4.3 for both mesquite and hybrid poplar. The table presents the sensitivity of the discounted average cost to variations in

Table 4.3. Sensitivity of discounted average cost to rariations in productivity and major system component costse

\begin{tabular}{lll}
\hline \multicolumn{1}{c}{ Item } & \multicolumn{2}{c}{ Range in discounted average cost (\$/GJ) } \\
\cline { 2 - 3 } & Mesquite & Hybrid poplar \\
\hline $20 \%$ variation in yield & 1.92 to 2.40 & 1.98 to 2.38 \\
$100 \%$ variation in number of coppices & 2.15 to 2.32 & 2.28 to 2.42 \\
$20 \%$ variation in establishment costs & 2.08 to 2.26 & 2.32 to 2.45 \\
$20 \%$ variation in cultural management costs & 2.10 to 2.24 & 2.25 to 2.51 \\
$20 \%$ variation in harvesting costs & 2.05 to 2.29 & 2.26 to 2.50 \\
\hline
\end{tabular}

${ }^{\circ} \mathrm{A}$ real discount rate of $6 \%$ was used. Rotation ages for mesquite and hybrid poplar were six and five years, respectively. Base example assumes three coppices.

productivity and major biomass system component costs. The range of the discounted average cost is based on deviations from the initial value. Changing the yield by $20 \%$ (i.e., plus or minus $10 \%$ frem the initial value) would have an impact of $\$ 0.48$ per gigajoule for the mesquite and $\$ 0.40$ per gigajoule for hybrid poplar. The effect of varying the number of coppices from a base value of three to two and four produces a range in discounted average cost of only \$0.17 and \$0.14 per gigajoule for mesquite and hybrid poplar respective!y. Variations in initial establishment cost result in similar changes for both species and about the same range as the variation examined for coppices. The sensitivity of discounted average cost to variations in harvesting cost is greater than that of either the number of coppices or establishment costs for both species.

Sensitivity analysis as represented by the example presented here is very useful in identifying the more important cost parameters and defining the acceptable range of variation in various system parameters. The results of sensitivity studies can indicate where limited researcu funds should be directed to have the greatest impact on economic viability. 


\title{
4.2.3 Optimal Stockpiling
}

\author{
T. R. Curlee
}

During FY 1983, work was done to modify and run an optimal stockpiling model to address several questions concerning both public and private domestic oil stocks. The model uses calculus of variations and explicitly considers the cost of adjustment in determining the optimal level of private and public stocks to respond to probabilistic supply disruptions.

After developing a base-case probabilistic disruption scenario, the model was run io estimate the optimal public and private stockpiles, as well as the expected discounted economic losses of the probabilistic disruption. The base-rase scenario (consisting of 17 parameter inputs) was developed after reviewing numerous documents. Many inputs (e.g., the oil price path, domestic quantity demanded, and domestic quantity supplied) were taken from the base-case scenario used in the reient study by the Energy Modeling Forum. ${ }^{7}$ Elasticity estimates, storage costs, and adjustment parameters were develcped as functions of several previous studies in those areas. The base-case disruption scenario calls for a disruption of 0.43 million metric tons per day $(3,000,000 \mathrm{bbl} / \mathrm{day})$, with an inception probability of 0.20 and a continuation probability (the probability that the disruption will last one year or longer) of 0.10 ." The model was then run with numerous variations of the base-case scenario to test the sensitivity of the major model outputs to different input parameters. Table 4.4 summarizes twelve of the model runs.

One of the most interesting applications of the model concerns how the optimal stakpiles and expected economic losses are altered by variations in the degree to which the domestic market can adjust to the oil price increases that accompany a disruption. Model runs were done in which the short-run supply-and-demand price elasticities were changed by small amounts. (The elasticity changes reflect the degree to which the market can adjust instantaneously.) Runs were also done in which the speed at which the short-run supply-and-demand curves move along the long-run curves was varied. Table 4.5 reports the impacts of varying the elasticities on the key model outputs, while Table 4.6 summarizes the impacts of altering the speed at which the market adjusts over time, given an oil price change. As can be seen from Table 4.5, changing the short-run elasticities by small anounts (which could, for example, reflect additional fuel-switching capacity) results in large changes in both the optimal stockpiles and economic losses under the high-continua:ion-prebability case. How:ver, as is reflected in Table 4.6, changing the speed at which the market adjusts (which could, for example, result from the surge-deployment benefits of $R \& D$ in synthetic fuels) has little impact on either the optimal stockpiles or the expected economic losses.

\subsubsection{Pricing Cogenerated Electricity}

\section{A. Trumble}

In the pursuit of efficient electricity production, one promising course is to encourage industrial cogeneration. Cogeneration in this context refers to the coproduction of electricity and thermal

The hairels-per-metric-ton figure varies depending on the type of crude. The American Petroleum Institute estimate that 1 metric ton is equivalent to $6.998 \mathrm{bbl}$ of foreign crude and $7.463 \mathrm{bbl}$ of domestic crude. All conversions here are made in terms of foreign crude. 
Table 4.4. Base-case resutes and seasitivity of paraneter rabes

\begin{tabular}{|c|c|c|c|c|}
\hline \multirow{2}{*}{ Sensitivity case } & \multicolumn{2}{|c|}{$\begin{array}{l}\text { Optimal } \\
\text { stockpile }\end{array}$} & \multicolumn{2}{|c|}{$\begin{array}{l}\text { Total expected } \\
\text { economic loss }\end{array}$} \\
\hline & Private ${ }^{b}$ & Publicr & Private & Public \\
\hline 1. Base case & 0 & 94.5 & 86.3 & $\$ 5.9$ \\
\hline $\begin{array}{l}\text { 2. Foreign stocks decreased from } \\
14.3 \text { million metric tons to zero }\end{array}$ & 13.8 & 105.8 & 86.3 & 59.9 \\
\hline $\begin{array}{l}\text { 3. Inception probability lowered from } \\
0.20 \text { to } 0.15\end{array}$ & 0 & 66.9 & 70.4 & 48.8 \\
\hline $\begin{array}{l}\text { 4. Continuation probability raised } \\
\text { from } 0.10 \text { to } 0.50\end{array}$ & 23.0 & 295.8 & 224.1 & 153.6 \\
\hline $\begin{array}{l}\text { 5. World oil price increase resulting } \\
\text { from 0.14-million-metric-ton-per-day } \\
\text { (mmtpd) disruption lowered from } \$ 12 \text { to } 55\end{array}$ & $\mathbf{0}$ & 38.9 & 48.8 & 35.4 \\
\hline 6. A combination of Cases 4 and 5 & 19.4 & 124.1 & 98.8 & 66.3 \\
\hline 7. Storage costs raised from $\$ 7.00$ to $\$ 11.89$ & 0 & 80.9 & 91.0 & 61.0 \\
\hline 8. Storag: costs lowered from $\$ 7.00$ to $\$ 2.24$ & 6.6 & 110.8 & 80.1 & 50.1 \\
\hline 9. A combination of Cases 2 and 7 & 8.7 & 91.8 & 91.0 & 65.7 \\
\hline 10. A combination of Cases 2 and 8 & 20.7 & 121.6 & 80.1 & 53.5 \\
\hline $\begin{array}{l}\text { 11. Base quantity supplied lowered to } \\
1.24 \mathrm{~mm} \text { tpd and quantity demanded } \\
\text { raised to } 2.93 \mathrm{~mm} \text { tpd }\end{array}$ & 0 & 124.4 & 119.8 & 64.4 \\
\hline $\begin{array}{l}\text { 12. Base quantity supplied raised to } \\
1.57 \mathrm{~mm} t \mathrm{pd} \text { and quantity demanded } \\
\text { lowered to } 2.48 \mathrm{mmtpd}\end{array}$ & 0 & 59.2 & 56.5 & 44.3 \\
\hline
\end{tabular}

-Stockpiles in millions of metric tons.

Optimal private stocks are those stocks which maximize the profits of individual firms, assuming that the behavior of all other firms is fixed.

The socially optimal stockpile minimizes the present discounted value of the total expected economic losses (inclusive of surplus losses) associated with the disruption itself and with preparations for the disruption.

"Losses in billions of dollars.

'Measured in dollars per metric ton.

Table 4.5. Impacts of short-rive elasticity clanges

\begin{tabular}{|c|c|c|c|c|c|c|}
\hline $\begin{array}{l}\text { Short-run demand elasticity } \\
\text { Short-run supply elasticity }\end{array}$ & $\begin{array}{r}-0.21 \\
0.03\end{array}$ & $\begin{array}{r}-0.24 \\
0.05\end{array}$ & $\begin{array}{r}-0.26 \\
0.07\end{array}$ & $\begin{array}{r}-0.30 \\
0.10\end{array}$ & $\begin{array}{r}-0.35 \\
0.13\end{array}$ & $\begin{array}{r}-0.50 \\
0.20\end{array}$ \\
\hline \multicolumn{7}{|c|}{ Base case } \\
\hline Private optimal stockpile & 0 & 0 & $\mathbf{0}$ & 0 & 0 & 0 \\
\hline $\begin{array}{l}\text { Expected economic loss: } \\
\text { private case }\end{array}$ & 86.3 & 82.2 & 79.1 & 73.5 & 66.9 & 48.1 \\
\hline Social optimal stockpile & 94.3 & 91.5 & 88.6 & 83.6 & 76.3 & 44.4 \\
\hline $\begin{array}{l}\text { Expected economic loss: } \\
\text { social case }\end{array}$ & 55.9 & 55.0 & 54.4 & 53.1 & 51.4 & 45.1 \\
\hline \multicolumn{7}{|c|}{ Higb-continuntion-probability case } \\
\hline Private optimal stockpile & 23.1 & 23.1 & 23.1 & 23.1 & 23.1 & 23.1 \\
\hline $\begin{array}{l}\text { Fxpected economic loss: } \\
\text { private case" }\end{array}$ & 224.1 & 213.3 & 205.1 & 190.2 & 172.6 & 122.6 \\
\hline Social optimal stockpile" & 295.7 & 286.6 & 277.0 & 260.8 & 238.8 & 119.4 \\
\hline $\begin{array}{l}\text { Expected economic loss: } \\
\text { social sase" }\end{array}$ & 152.6 & 150.1 & 148.2 & 144.4 & 139.5 & 120.1 \\
\hline
\end{tabular}

"Stocks in millioiss of metric tons.

bosses in billions of dollars. 
Table 8.6. Inpacts of varying the adjothent paranetes

\begin{tabular}{|c|c|c|c|c|c|c|c|c|}
\hline & \multicolumn{8}{|c|}{ Percentage of reduction in adjustment times from base case } \\
\hline & Base & 1 & 5 & 10 & 20 & 30 & 40 & 50 \\
\hline$\lambda_{1}{ }^{\bullet}$ & 0.1 & 0.1 & 0.1 & 0.1 & 0.2 & 0.2 & 0.2 & 0.2 \\
\hline$\lambda_{2}^{*}$ & 2.0 & 2.0 & 2.1 & 2.2 & 2.5 & 2.9 & 3.3 & 4.0 \\
\hline \multicolumn{9}{|c|}{ Percentage adjustineat at the $T$} \\
\hline Time, years & & & & & & & & \\
\hline 0.5 & 2.2 & 2.2 & 2.4 & 2.6 & 3.1 & 3.9 & 4.9 & 6.5 \\
\hline 1 & 6.5 & 6.6 & 7.0 & 7.6 & 9.0 & 10.7 & 13.1 & 16.4 \\
\hline 2 & 16.4 & 16.6 & i7.5 & 18.7 & 21.2 & 24.5 & 28.7 & 34.2 \\
\hline 3 & 25.8 & 26.1 & 27.2 & 28.3 & 32.2 & 36.4 & 41.6 & 48.2 \\
\hline 5 & 41.6 & 42.0 & 43.4 & 45.4 & 49.7 & 54.9 & 60.9 & 68.0 \\
\hline 12 & 74.8 & 75.2 & 76.6 & 78.5 & 82.4 & 86.4 & 90.3 & 94.0 \\
\hline 20 & 90.3 & 90.6 & 92.5 & 92.6 & 94.7 & 96.5 & 98.1 & 99.1 \\
\hline Average adjustment time, years & 8.8 & 8.7 & 8.4 & 8.0 & 7.1 & 6.2 & 5.3 & 4.4 \\
\hline \multicolumn{9}{|c|}{ Base case } \\
\hline Private optimal stockpileb & 0 & 0 & 0 & $\mathbf{0}$ & $\mathbf{0}$ & $\mathbf{0}$ & 0 & 0 \\
\hline $\begin{array}{l}\text { Expected economic loss:e } \\
\text { private case }\end{array}$ & 86.3 & 86.3 & 86.3 & 86.3 & 86.2 & 86.1 & 86.0 & 85.8 \\
\hline Social optimal stockpile ${ }^{b}$ & 94.5 & 94.5 & 94.5 & 94.5 & 94.4 & 94.3 & 94.2 & 93.9 \\
\hline $\begin{array}{l}\text { Expected economic loss:" } \\
\text { social case }\end{array}$ & 55.9 & 55.9 & 55.9 & 55.9 & 55.8 & 55.8 & 55.7 & 55.7 \\
\hline \multicolumn{9}{|c|}{ High-contimantion-probability case } \\
\hline Private optimal stockpile ${ }^{b}$ & 23.1 & 23.1 & 23.1 & 23.1 & 23.1 & 23.1 & 23.1 & 23.1 \\
\hline $\begin{array}{l}\text { Expected economic loss:" } \\
\text { private case }\end{array}$ & 224.1 & 224.0 & 223.5 & 222.8 & 221.2 & 218.9 & 215.6 & 210.8 \\
\hline Social optimal stockpile ${ }^{b}$ & 295.8 & 295.8 & 294.5 & 294.0 & 291.8 & 288.6 & 283.9 & 277.0 \\
\hline $\begin{array}{l}\text { Expected economic loss: } \\
\text { social case }\end{array}$ & 152.6 & 152.6 & 152.4 & 152.1 & 151.5 & 150.6 & 149.3 & 147.5 \\
\hline
\end{tabular}

The $\lambda$ 's define the speed at which the short-run curves move along the long-run curves. Stocks in millions of metric tons.

'Losses in billions of dollars.

energy from a single heat source. Compared to the typical situation of separate production, a cogeneration system may result in a more efficient use of resources because of the dual energy output.

To mitigate the barriers potential cogeilerators may face, the Federal Energ; Regulatory Commission (FERC) has issued rules for power transaction between cogenerators and utilities. Under these guidelines, utilities must purchase power from cogenerators at the utility's "full avoided cost" (FAC). The objective of this study (which was sponsored by EIA) was to examine sume of the implications of this pricing rule. Our investigation deals with the theoretical and practical aspects separately.

A simple model with one large utility and several small cogenerators is used to characterize alternative pricing policies. A comparison of these benchmark cases illustrates the implications of different decision criteria in terms of a trade-off between production efficiency and the distribution 
of income. We interpret an FAC pricing policy as setting price at what the utility's average cost would be for producing that additional amount which is the total supply of cogenerated electricity. We demonstrate that this form of FAC pricing is inefficient in the sense of minimizing the tota! production costs of electricity when there is more than one cogenerator and the utility exhibits local decreasing or increasing returns to scale. This claim also depends on how each cogenerator views the actions of the other cogenerators. Both simple and more complicated assumptions regarding the interaction of cogenerators lead to similar conclusions of inefficiency although the magnitude will vary.

In considering some of the practical aspects of pricing cogenerated electricity, a number of issues such as time-of-day demand, scheduling, and reliability need to be addressed. The proposed p ins for implementing an FAC policy only roughly approximate the utility's aroided cost in purchasing electricity when these factors are taken into account. At best, the utility's expected cost will remain constant, while the variance of cost will most likely increase. In general, the bearing of risk and its associated cost are ignored in implementation plans. It is suggested that a reserve margin, such as a percentage of the computed FAC price, be used to cover hidden costs such as risk premiums. Alternately, it may be desirable to explore different risk-bearing arrangements.

\subsubsection{Simulation of Liberian Energy Demand}

\section{J. Hill}

The purpose of this study was to analyze end-use, sectoral energy demand in Liberia, West Africa, over the 1981-2000 time horizon. The research wis undertaken as one component of a much broader integrated energy assessment of Liberia (Sect. 7.2.1). Other components of the assessment, however, were focused on current energy supply and demand, together with future energy supply options for Liberia. This particular study was devoted exclusively to an aralysis of Liberian energy demand.

The methodology used to simulate Liberian sectoral energy demand over the period 1981-2000 involved the recursive interaction of a macroeconomic model and individual, econometrically estimated sectoral demand equations. That is, given projections for gross output in the Liberian economy from the macroeconomic model, sectoral energy demand was simulated. The individual energy demand equations were estimated on the basis of economic variables that are theorized tc influence energy consumption in the respective sectors (e.g., price, output).

It was, of course, infeasible to systematically consider the entire spectrum of plausible international scenarios over the 1981-2000 forecast horizon which will affect the Liberian economy. Therefore, four scenarios were selected for incurporation in the models for simulation purposes.

The first scenario provides an "upper bound" for the energy demand simulations executed in this study. That is, by assuming no real growth in the price of crude petroleum (and therefore no real growth in refined petroleum product prices) and very auspicious annual growth in the real price of Liberia's major exports over the 1981-2000 simulation period, Scenario 1 depicts a set of international conditions most conducive to substantial real aggregate growth of the Liberian economy and consequent high levels of energy use.

In contrast to Scenario 1 , the second scenario was executed under the assumption that the real annual growth in the world price of crude petroleum will mirror the 1982 mid-range world oil price 
projections provided by EIA. The growth rates used were $0.6 \%, 8.2 \%$, and $4.3 \%$ for the periods 1981-1985, 1985-1990, and 1990-2000 respectively.

The intent of Scenarios 3 and 4 was to examine the impact on total eneigy demand of less optimistic projections of trends in Liberia's cconomic condition. In order to investigate that possibility, it was assimed in Scenario 3 that the Liberian American Swedish Mining Company (LAMCO) will totally withdraw from its Liberian operations in 1985 and that the Bong Mining Company (BMC) will withdraw in 1990. It was further assumed that rubler production would decline by two-thirds in 1990. Scenario 3, therefore, can be viewed as a "lower bound" on the energy demand simulations provided in the study.

Scenario 4 was devised to reflect a more gradual decline in Liberian production for export markets. For this scenario, therefore, it was explicitly assumed that the decline in production for exports was one-half of that reflected in Srenario 3.

The annual growth rates (in percentages) for aggregate energy use in the Liberian economy over the 1981-2000 time horizon which were obtained from the four simulations can be concisely summarized as follows:

Total

(excluding Wood/ Grand

\begin{tabular}{|c|c|c|c|}
\hline Scenario & wood/charcoal) & charcoal & total \\
\hline 1 & 4.8 & 3.0 & 3.8 \\
\hline 2 & 1.2 & 3.0 & 2.3 \\
\hline 3 & -1.8 & 3.0 & 1.5 \\
\hline 4 & -0.6 & 3.0 & 1.8 \\
\hline
\end{tabular}

The annual growth rates for energy demand over the 1981-2000 period depicted in the table for the four scenarios were based on simulated annual growth rates in the macroeconomy over that same period of $3.4 \%, 2.8 \%, 0.8 \%$, and $1.9 \%$ for Scenarios 1 through 4 respectively.

The primary conclusion drawn from the analysis is that, besides iveing sensitive to changes in international economic activity, the demand for energy in Liberia over the 1981-2000 time period is highly sensitive to internal production of its two primary exports: iron ore and rubber. More specifically, as characterized in the four scenarios, future growth in Liberian energy demand is contingent on the output of three companies: LAMCO, BMC, and the Firestone Rubber Company.

\subsubsection{Headwater Benefits}

R. D. Perlack
S. M. Cohn
C. G. Rizy
S. Das ${ }^{\dagger}$
A. F. Turhollow

The objective of this two-year project was to pr svide technical assistance to FERC through the EIA to study the process for determining headwater benefits. Headwater benefits have heen defined as annual gains in generated hydroelectric energy and increases in dependable cafacity available at

\footnotetext{
Because of data limitations, it was assumed that the annual growth rate of wood/charcoal would reflect the growth in the Liberian population over the simulation period.

'Graduate student, University of Tennessee.
} 
a downstream power plant above the energy and capacity produced by the unregulated available streamflow. Under the Federal Power Act, beneficiaries of headwater benefits are mandaied to make a corresponding payment to the U.S. Treasury.

Resource and Environmental Analysis staff documented, validated, and evaluated the computer model used by FERC to compute annual energy gains. "The model is a complex streamflow accounting framework that uses empirical reservoir operating rules and hydropower plant rating equations to determine energy generated under varying conditions of upstream reservoir operation. The documentation process provided a basis to evaluate the strengths and weaknesses of the FERC modeling procedures. The evaluation was focused on two key areas, the sensitivity of the model to key parameters and the effectiveness of the model for FERC's intended purpose.

The extended sensitivity analysis indicated that, because of a built-in correction factor, the apportionment of headwater site costs to downstream beneficiaries tended to be relatively insensitive to changes in important model parameters. A statistical analysis of two major components of the model-the reservoir operating rules and the hydropower plant rating equations-revealed that major improvements could be made in the simulation accuracy of the model only at a considerable increase in FERC staff time and cost. In general, it was found that the model worked as intended and that several improvements could be made to make the model run more efficiently, thereby relieving time and cost constraints on the part of FERC staff. ORNL consequently revised the model and implemented several other modifications so that the model code conformed to structured programming techiniques.

ORNL developed an improved technique for determining and valuing dependable capacity gains. The procedure is based on the principle of effective load-carrying capability, which is measured as the increase in load that can be carried at equal system reliability with the added capacity resulting from upstream streamflow regulation. This new method avoids the pitfalls of past FERC procedures couched in terms of arbitrary definitions of the critical period.

The quantified gains in energy and dependable capacity are used by FERC staff in the appurtionment of headwater site costs to the downstream beneficiaries. ORNL staff reviewed the procedures used by FERC to assess headwater benefits charges. This review indicated that the procedures recently adopted by FERC for apportionment and cost allocation would greatly facilitate the investigation of headwater benefits. ORNL also concluded that the use of sophisticated production costing methods in the apportionment process would not be cost-effective in terms of providing a better basis for assessing annual charges to downstream beneficiaries.

The final task for staff members was to help FERC identify river basins in which headwater benefits might exist and therefore warrant an investigation. ORNL developed a computer program that extracted data from the FERC Hydropower Inventory Data File and then identified situations of possible headwater benefits. The model improvements and associated recommendations, along with the newly instituted FERC apportionment procedures, will greatly increase and expedite the collection of charges for headwater benefits as required by the Federal Power Act.

\title{
4.2.7 End-Use Models
}

\author{
D. M. Hamblin
}

Although end-use model enhancements continued to be focused in the residential sector, modifications to the commerical, industrial, and residential sector models were accomplished as a 
necessary adjunct to the assessment of CRBR power. These enhancements to analytical capability were required because of the anticipated service life of the reactor and because of the project need to consider potential service areas geographically differeat from the DOE Federal Region definition underlying the data bases for the ORNL buildings sector models (residential and commercial). First, building sector model structures were modified to permit long-range (out to year 2020) simulations. Second, reaggregation procedures were developed and implemented which accommodate the determination of historical building stocks (commercial floor space and households) from state- and county-level prociuction data. Third, an algorithm and supporting data were developed for modifying base-period projections of the intensity of energy use for space conditioning (heating and cooling) on the basis of historically determined elasticities of the sela-itivity of energy use to changes in heating degree-days for space heating and changes in cooling degree-days í. space cooling.

In the residential sector, development work continued on the full and logically consistent characterization of the new structure choice of energy service technologies and fuel. For a Pacific Northwest data base emanating from the Bonneville Power Administration (BPA) Division of Power Requirements, a nested logit choice of fuel and equipment for ten space heating systems (i.e., central forced air, noncentral, and hydronic-each fueled by electricity, natural gas, or oil-plus electric heat pumps); three water heating choices (i.e., electric, natural gas, or oil); two cooking choices (i.e., electric or natural gas); and three clothes drying choices (i.e., electric, natural gas, or none) was fully implemented.

The classical programming framework for shell and equipment efficiency choice was modified in two ways. First, for each building type (i.e., single family, multifamily, mobile home), model structure was extended to permit simultaneous optimization (of shell thermal integrity, space heating and cooling efficiency, and water heating efficiency) for up to 81 unique configurations of equipment type and fuel (e.g., gas central forced-air heat, room air conditioning, and electric water heating). In support of this modification, structure was enhanced to simulate heat pump choice as a function of its joint amenity attractiveness for heating and cooling. Second, a methodology was developed and implemented for using technology choice Lagrange multiplier shadow prices associated with programmatic conservation initiatives in the simulated choice of fuel-and-equipmeisc type.

Conservation initiatives might include aggregate building energy performance standards, or prescriptive standards on the efficiencies of particular energy service equipment, and/or the thermal transmittance characteristics of the building envelope. The model can simulate "boundary conditions" on the impacts of policies by depicting their influence under differing notions about consumer price expectations. The upper bound for "beneficial" policy impact is portrayei under the "static" price expectations hypothesis that builders and consumers fail to anticipate future increases in the real price of energy. The lower bound is portrayed under the "rational" price expectations hypotinesis that decision makers incorporate predictions of future real energy price increases into their private choices of energy service capital. The function of the Lagrange multiplier shadow prices in fuel-and-equipment choice is to depict the standard-induced fuel-switching impacts under the differing price expectations assumptions. The rationale for this is that, for example, a fuelspecific standard for "tight" electrically heated houses in force over a forerasting horizon of "flat" electricity prices or, equivalently, under an assumption of static electricity price expectations-will entail expenses which builders believe cannot be passed on to consumers. In light of this, the shadow price impact on fuel choice depicts the builder's tendency to switch away from construction 
of electrically heated homes into alternatives that have retained profit-taking opportunities. The primary stimulus for these enhancements has been to improve the model's aggregation properties. By disaggregating the new housing stock into up to 81 configurations per building type and determining energy use based on technical and economic characteristics of these "reference houses," the residential sector model now encompasses a fully implemented "market segmentation" approach to mitigating aggregation biases. The crenlibility and cost-effectiveness of this approach will be independently assessed and validated for the ORNL model supported by the Pacific Northwest data base.

Two additional substantive enhancements to the residential sector model are currently underway. Using a two-step estimation procedure developed by J. A. Dubin and D. L. McFadden, second-step usage equations (employing nested logit results as first-step instrumental variables) are currently being estimated. This work-being performed by Jerry Hausman and Reed Shuldiner of Massachusetts Institute of Technology-romplements and is internally consistent with the first-step estimation performed by Berkovec, Hausman, and Rust. ${ }^{10}$ Model structure is being extended to employ these new results in simulation. This accomplishment will result in fuel choice and usage econometric components that are fully consistent with the engineering/technology-based simultaneous optimization and efficiency determination. Also, a long-standing need for endogenous characierization of the shell retrofit decision is being addressed in model structure enhancements.

Finally, the residentia! sector model is undergoing comprehensive redorumentation under a joint ORN ${ }^{*}$-/BPA project initiated in late FY 1983.

\subsection{RESEARCH UTILIZATION}

The research conducted by the Economic Analysis Section has had several research products used by both government agencies and by individuals and firms in the private sector. Two regulatory impact statements were prepared (for the Residential Conservation Service and the Commercial and Apartment Conservation Service) to indicate the costs and benefits expected from the programs. These were published by DOE to comply with Executive Order No. 12291.' Similarly, a study entitled "Technical and Environmental Aspects of Electric Power Transmission" is currently used within the DOE Office of Environmental Compliance in evaluating environmental impact statements on power lines.

Sometimes research products form the basis for further work within an agency. An electricity market analysis identified potential purchasers of electric power produced by the CRBR Project and was used by project staff in p:eparing congressional testimony. The FERC used information contained in an evaluation of forecasts produced by the National Utility Financial Statement Model in a commission decision regarding the regulatory treatment of Construction Work in Progress. In one instance, research products have been directly used by firms in the private sector; the macroeconomic model for forecasting Liberian energy demand (Sect. 4.2.5) was used by Arthur D. Little, Inc., to evaluate the economic viability of a Liberian refinery.

The FIRSTCUT Model developed under the auspices of the Biomass Technology Program has recently been used in an analysis of biomass potential in Liberia for the Agency for International

On February 17, 1981, the President issued Executive Order 12291. According to this order, before taking action, regulatory agencies must send all proposed regulations and regulatory impact analyses to the Office of Maragement. and Budget for review. 
Development. Although the herbaceous crops project is a relatively new area, staff members working on the project have discussed common areas of research directions with the New York State Energy Research and Development Authority. As an outgrowth of the work initiatsd for the Nuclear Power Plant Investment Study, briefing seminars on the EIA-254 data base documented by ORNL were presented to the U.S. Nuclear Regulatory Commission, Office of Nuclear Energy, and at the "Workshop on the Costs of Nuclear Power Plants," conducted by Oak Ridge Associated Universities. Several of the industrial energy data bases developed for a study evaluating the potential impact of industrial structural change on electricity demand were presented at the Electric Power Research Institute's workshop, "Forecasting Industrial Structural Change in the U.S." This information was also used as background material for an ongoing ORNL study examining trends in the electric utility industry.

The Residential End-Use Model was transferred to Iowa State University under the auspices of the lowa Commerce Commission. The model has also been transferred and is currently being enhanced for application in the northwestern United States for the BPA, Division of Power Requirements. This transfer has involved an off-site assignment for D. M. Hamblin to implement the model at Bonneville, as well as to provide the model as a public domain model for use by the Pacific Northwest Regional Power and Conservation Planning Council. Hamblin also presented the invited keynote speech for the "Symposium on Computer Analysis on Electric Load Forecasting and Generating Capacity Expansion." The symposium, cosponsored by the National Regulatory Institute and Ohio State University, was presented for technical specialists as well as representatives of state, national, and international regulatory and public utility commissions. The Buildings

Innovation Economic Analysis Model for economic analysis of conservation innovations developed for DOE has been transferred to EIA and Battelle-Northwest and is the model being used in cooperation with the American Society of Heating, Refrigeration, and Air-Conditioning Engineers (ASHRAE). Finally, a briefing on the Integrated State-Level Forecasting Model was presented at the conference, "Electric Utility Load Forecasting," sponsored by the Maryland Power Plant Siting Program.

\subsection{REFERENCES}

1. J. W. Van Dyke, Benefit-Cost Aspects of Long-Term Isolation of Uramium Mill Tailings, ORNL/TM-8686, Oak Ridge National Laboratory, November 1983.

2. D. J. Bjornstad and R. C. Tepel, Commercial and Apartment Conservation Service Regulatory Impact Analysis, DOE/CE-0051, U.S. Department of Energy, Office of Buildings Energy Research and Development, July 1983.

3. S. S. Shen and A. Turhollow, "Regional Impacts of Herbaceous and Woody Biomass Production in U.S. Agriculture," in Energy from Biomass and Wastes, Vol. VII, Institute of Gas Technology, Chicago, 1983.

4. D. M. Hamblin et al., Clinch River Breeder Reactor: An Assessment of the Need for Power and Regulatory Issues, ORNL/TM-8892, Oak Ridge National Laboratory, September 1983.

5. 1982 Annual Report to Congress, DOE/EIA-0173(82)/1. U.S. Department of Energy, Energy Information Administration, Washington, D.C.

6. W. Barrun, R. Perlack, P. Kroll, J. Cushman, and J. Ranney, FIRSTCUT: A Preliminary Assessment Model for Short-Rotation Intensive Culture, ORNL/TM-8566, Oak Ridge National Laboratory, November 1983.

7. World Oll: Summary Report, EMF Report 6, Energy Modeling Forum, Stanfurd University, Stanford, Calif., February 1982. 


$$
73 / 74
$$

8. R. D. Perlack, A. F. Turbollow, S. Das, S. M. Cohn, and C. G. Rizy. The Headwater Benefils Emery Gains Model Description and Users Manual, ORNL/TM-8395, Oak Ridge National Laboratory, January 1984.

9. J. A. Dubin and D. L. McFadden, "An Econometric Analysis of Residentiai Electric Appliance Holdings and Consumption" (to be published in Econometrica).

10. J. Berkovec, J. Hausman, and J. Rust, "Heating System and Appliance Choice,"Studies in Energy and the American Economy. MIT-EL 83-004WP, Massachusetts Institute of Technology, Energy Laboratory, January 1983. 


\title{
5. Data and Analysis Section
}

\author{
A. S. Loebl
}

\subsection{INTRODUCTION}

The Data and Analysis Section (DAS) has undergone significant growth and development during FY 1983 while continuing to support its lead mission for the research and analysis funded by the Energy Information Administration (EIA) of the U.S. Department of Energy (DOE). The evaluation of energy conservation programs continued under both DOE sponsorship and non-DOE sponsors, including the Tennessee Valley Authority (TVA), the Electric Power Research Institute (EPRI), and the Bonneville Power Administration (BPA).

DAS staff skills and interests in data and model validation, as well as their understanding of data management and automatic data processing systems development, have been recognized as particularly well suited to many needs of both DOE and non-DOE federal agencies. The development of what we have come to call our Data Systems R\&D Program began with our traditional sponsors but has grown to include 13 agencies of the U.S. Department of Defense (DOD), the Bureau of Land Management of the U.S. Department of the Interior, and the Immigration and Naturalization Service of the U.S. Department of Justice.

The Data Systems R\&D Program focuses on coordinating and conducting short-term and longer-term state-of-tne-an theoretical and applied research that will contribute to increased knowledge on the use of advanced data systems. This program emptasis is enhanced through development of the capability to provide technical expertise required for the design, development, and operation of all hardware/software components with the complete, integrated architectures of actual, mission-oriented, and user-specific decision-support computer data systems. DAS activities are directed toward enhancing the logistics. manpower, and materials data systems for the sponsoring agencies, with an emphasis on R\&D aspects of designing decision-support systems; developing data system architectures; conducting data system requirements studies; and developing state-of-the-art methods and approaches that will result in the experience and skills necessary to cope with the accelerating transition from third- to fourth- and eventuaily to fifth-generation computer and communication technology.

For example, a number of DOE and non-DOE sponsored projects have been focused on developing and implementing the best computer structures for accomplishing certain tasks. Research on architectures devoled to discovering such structures for accomplishing powerful problem-solving as well as data management/access/retrieval functions may result in models of architectures for artificial intelligence systems in new and emerging fourth- and fifth-generation environments. 
Work conducted for DAS sponsors in FY 1983 included applied research in evaluating existing energy data systems and models, formulating specifications for data and data base management systems (DBMSs), and understanding how data systems and technology fit into organizations. We began more fundamental research focused on methodology development for data collection and data analysis; determining how data systems are needed in decision making; and understanding both man-machine and machine-machine interface requirements. Finally, we have begun work in decision-support systems and knowledge representation.

The non-DOE work underway initially grew as a result of experience gained from our continuing DOE responsibilities in energy data analysis and program evaluation as well as the automated data system tasks performed as part of the EIA program. In reaching out for funding that DOE has been unable to provide, we have been able to pursue data systems R\&D that will support DOE programs as well." All FY 1983 projects conducted for non-DOE sponsors dealt with designing new automated data systems, upgrading current data systems, reviewing existing data systems to ensure that needs were being satisfied, and evaluating state-of-the-art software and hardware for military nontactical applications.

The progress during FY 1983 described here includes highlights of projects and tasks that are representative of the work of the four groups of the DAS - the Evaluation Group, the Data Methods Group, the Systems Development Group, and the Systems Analyzis Group. These highlights were selected to show the breadth of the DAS project responsibilities. DAS-led projects involved contributions of staff from all sections of the Energy Division and from eight other divisions of Oak Ridge National Laboratory (ORNL) and significant contributions from many private subcontractors and consultants. Thus, it is the responsibility of DAS research staff to both participate technically on appropriate projects and provide program direction as DAS draws upon the large disciplinary resources of ORNL and support from outside ORNL. During FY 1983 a special advisory committee was organized to consult on matters related to the development of the energy and nonenergy programs of DAS.

\subsubsection{Evaluation Group}
E. A. Hirst ${ }^{\dagger}$
L. G. Berry ${ }^{\ddagger}$
B. E. Tonn"
R. T. Goeltz
D. L. White'

The Evaluation Group continued their analysis of government and utility energy conser program impacts. The major objectives of the Energy Division's evaluation activities are (1) to document the performance of government and utility conservation programs and (2) to provide

\footnotetext{
"For example, work at the state-of-the-art level in perallel-processing techniques to support computer performance needs of the Department of the Army has also provided input to assist DOE in understanding fault-tolerant transaction processing that might support its nuclear safeguards program data base. Also, benefiting from work on advanced data base management techniques for design and development of decision support systems for the Navy Fleet Modernization Program, the ORNL Foceil Energy Technology Environmental Program will be asuisted by DAS in quality asurance of its fully integrated DBMS.

'Group Leader.

tPart-time.

'Dual capacity.

'Graduate student.
} 
feedback to program managers to improve the operation and efficiency of these programs. The focus of work in DAS is on the former issue; staff in the Regional and Urban Studies Section (see Chap. 3) focuses primarily on the latter issue.

With respect to measurement of the benefits and costs of conservation programs, DAS work deals with (1) examination and analysis of recent trends in U.S. energy consumption; (2) analysis of the determinants of these changes, with a particular focus on the effects of government and utility conservation programs; and (3) development of data management and analytical techniques to support the first two issues.

During FY 1983, DAS staff worked on several evaluation projects:

1. evaluations (both quantitative and qualitative) of the BPA Residential Weatherization Pilot Program; ${ }^{1,2}$

2. evaluations of the federal Residential Conservation Service (RCS) programs in Connecticut and Minnesota; ${ }^{3,4}$

3. development of methods to select states for evaluation of RCS, such that results can be generalized to the United States as a whole;

4. review of financial incentives in utility conservation programs; 6

5. development of evaluation designs for the TVA to test the effects of financial incentives in their programs; ${ }^{7}$

6. development of sampling and analytical methods to deal with self-selection in conservation programs;

7. comparison of actual energy savings with audit predictions of energy savings in the Pacific Northwest (electrically heared homes) and Minnesota (gas-heated homes); 9,10

8. initiation of an evaluation of BPA's regionwide Residential Weatherization Program; and

9. analysis of recent trends in U.S. energy consumption."

\subsubsection{Data Methods Group}
G. A. Dailey
H. W. Bertini ${ }^{\dagger}$
E. C. Halbert
A. J. Shor
L. A. Clinard
M. R. Hilliard
C. E. Snyder
S. Cantor
D. Y. Kelly ${ }^{\dagger}$
M. P. Stulberg
S. M. Cohn ${ }^{\dagger}$
G. E. Liepins
H. J. Tsso
D. M. Flanagan
W. J. Pennewel!

The Data Methods Group (DMG) is evenly divided in support io DOE and to different segments of DOD. The support to DOE is decreasing as a function of annual budget reductions within DOE and of the decline in the federal government's perception of energy as a major national

\footnotetext{
Group Leader.

'Dual capacity.

tConsultant.
} 
concern. Support to the military is increasing as the DOD budget increases and the bandling of data becomes an obvious problem for each branch of service.

The interests of the group revolve around two major themes: (1) the analysis of energy issues and the improvement of energy data systems for EIA and (2) the study of automated data handling methods ir order to suggest/provide more up-to-date software or hardware to increase the efficiency of the data system. Also, the DMG is the center for the EIA program.

During FY 1983, the staff worked on several projects supporting the above themes. Studies included the following:

1. The completion of a review of data requirementis pertaining to the use of so-called alternate fuels within the United States, for example, solar, wind, biomass, geothermal, and hydro (see Sect. 5.2.2).

2. Initiation of a study, along with members of the Economic Analysis Section, to determine the viability of the U.S. uranium mining and milling iadustry (see Sect. 4.1.4).

3. Performing economic analyses, with staff in the Economic Analysis Section, of various segments of the natural gas market "e., the financial analysis of natural gas distribution companies).

4. Undertaking several major studies, with the Oak Ridge Associated Universities' Institute for Energy Analysis, of natural gas data pertaining to interstate natural gas pipelines and current capabilities within the private sector and the government for forecasting natural gas demand.

5. Support to the Marine Corps in the analysis of components of equipment failure and inventory usage data to develop an automated system for inventory control.

\subsubsection{Systems Analysis Group}

R. W. Barnes"
G. R. Hadder
B. E. Tonn ${ }^{\dagger}$
C. E. Hammons
T. A. Vineyard
S. S. Sterens ${ }^{\dagger}$
P. B. Zuschneid

The Systerns Analysis Group has undergone a majo" transition from research pertaining to residential, industrial, and commercial energy use to data systems R\&D focused on data management requirements and the determination of systems specifications. This area of work involves applied research on problems where state-of-the-art data management techniques must be used because rapid accessibility to specific data elements of massive data bases is critical. The combined transaction loads and data storage requirements of these systems exceed the capabilities of conventional third- and fourth-ger.eration computer systems. Research is directed toward increasing the efficient use of data (e.g., expert systems, data models, and datd interpretation) as well as toward more efficient handling (i.e., acquisition, storage, and retrieval) of data.

\footnotetext{
Group Leader

'Dual capacity.
} 
By building on work initially supported by DOE/EIA and using experienced personnel we were able to tap from ORNL's Fusion Energy Program, we have determined that through synergistic application of state-of-the-art methedology in data management systems, operating software, and computer processors, systems can be configured, prototyped, tested, and installed to satisfy the needs described above. The DOD has substantia,ly supported suci developmental efforts during FY 1983 in the areas of configuration management and systems architecture research pertinent to portions of their massive data collection and communications needs. During FY 1983, the staff worked on several projects, exemplified by the foilowing:

1. A project to enhance the accessibility and availability of Army materiel supply and distribution data for the Logistic Control Activity of the Department of the Army Materiel Deyelopment and Readiness Command (DARCOM) (see Sect. 5.2.7).

2. Development of a method for storing, retrieving, and reviewing data on all constituents of major Army equipment systems for DARCOM (see Sect. 5.2.5).

3. Development of data analysis techniques to understand the effects of reductions and interruptions of crude oil supply on domestic petroleum refining cperations for DOE/EIA (see Sect. 5.2.4).

\title{
5.1.4 Systems Development Group
}

\author{
H. G. Arnold
}
P. Y. Bengtson
R. S. Loffman
J. W. Grubb ${ }^{\dagger}$
M. M. Stevens
R. K. Gryder
S. L. Yount
D. Y. Kelly

The Systems Development Group (SDG) was organized during the third quarter of FY 1983 under the direction of $\mathbf{H}$. G. Aınold. The responsibilities of this group are focused on projects where data vstem $R \& D$ components include problems of data communications, man-machine interfaces, understanding the technology of data/information systems, and determining optimum architectures so that systems and technology can be appropriately fit into organizations.

During FY 1983, work was initiated on several projects:

1. Development, organization, and operation of the Navy Civlian Personnel Data System (NCPDS). a centralized jata system located in Oak $R_{\text {: }}$;ge winich interactively supports data inquiries and updates of Navy civilian personnel offices throughout the world.

2. Development and organization of a microcomputer laboratory to support the research needs of the Navy Military Personnel Command (NMPC). Representative microcomputer systems are evaluated for networking and communication compatibility for larger prototypical configurations in a controlled laboratory environment.

\footnotetext{
Group icader.

'Consultant.

'Dual crpacity.
} 
3. Specification of the conceptual design of a decision-support system. This type oi DBMS will be capable of extrapolating and interpreting its data base in support of decision makers.

4. Specification of a design for a comprehensive DBMS and hardware architecture for the Immigration and Naturalization Service (INS). This system will enable the INS to upgrade its existing Nonimmigrant Information System to include new categories such as nonresident stud:nts and to more effectively manage data on all categories and nonimmigrants.

5. Pre xaration of the functional desuiption for the Army Civilian Personnel Data System (ACFERS). The functional description will be used as the basis for specifying a personnel data management system that has as a minimum the capabilities of the NCPDS.

6. Design and development of an information architecture for the NMPC to provide them with a structure, for planning data automation across the command.

7. Establishing the interface requirements of telecommunications networks with specific hardware and software incompatibilities. In order for networks of computer users to communicate, it is necessary to establish technically compatible communications protocols among them and to provide conversion when incompatibilities exist.

\subsection{TECHNICAL HIGHLIGHTS}

\subsubsection{Evaiuation of Home Energy Audit and Loan Programs}

During the past year, we evaluated utility residential conservation programs in Connecticut, Minnesota, and the Pacific Northwest. This section will briefly discuss our evaluation of two programs operated by Northern States Power Company (NSP) in Minnesota-their home energy audit program [Minnesota's version of the federal Residential Conservation Service, called the Minnesota Conservation Service (MECS)] and a punt program that included low-interest loans for measures recommended in an MECS audit [called the Public Utility Conservation Investment Program (PUCIP)]. ${ }^{12}$

The evaluation involved collection of several types of data:

- monthly natural gas consumption records for program participants and nonparticipants from October 1980 through April 1983 (three heating seasons);

- heating degree data for each weather station (three) and billing cycle (21);

- energy audit reports for MECS and PUCIP participants;

- household demographics, structure characteristics, and information on recent and planned conservation actions (mail survey);

- detailed information on receni cunservation actions (what, when, who did it, at what cost) and on energy-related attitudes (subsequent telephone survey).

Usable mail survey and fuel bills were available for $11 \mathrm{mmst} 3500$ households; telephone survey data were available for 1000 of these households.

Such a detailed data set was required to adequately analyze changes in energy consumption which could be directly attributed to the NSP programs. There was stostantial preprogram variation in energy consumption across households (Fig. 5.1); without sufficient information on the 


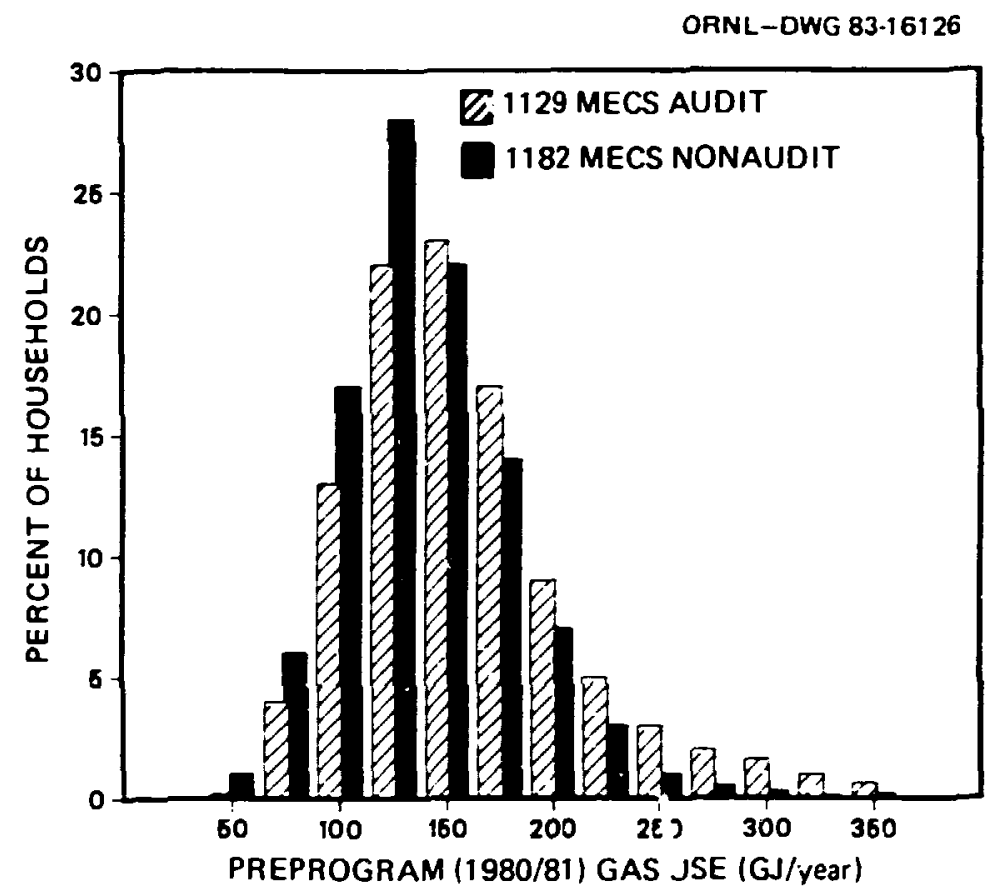

(a)

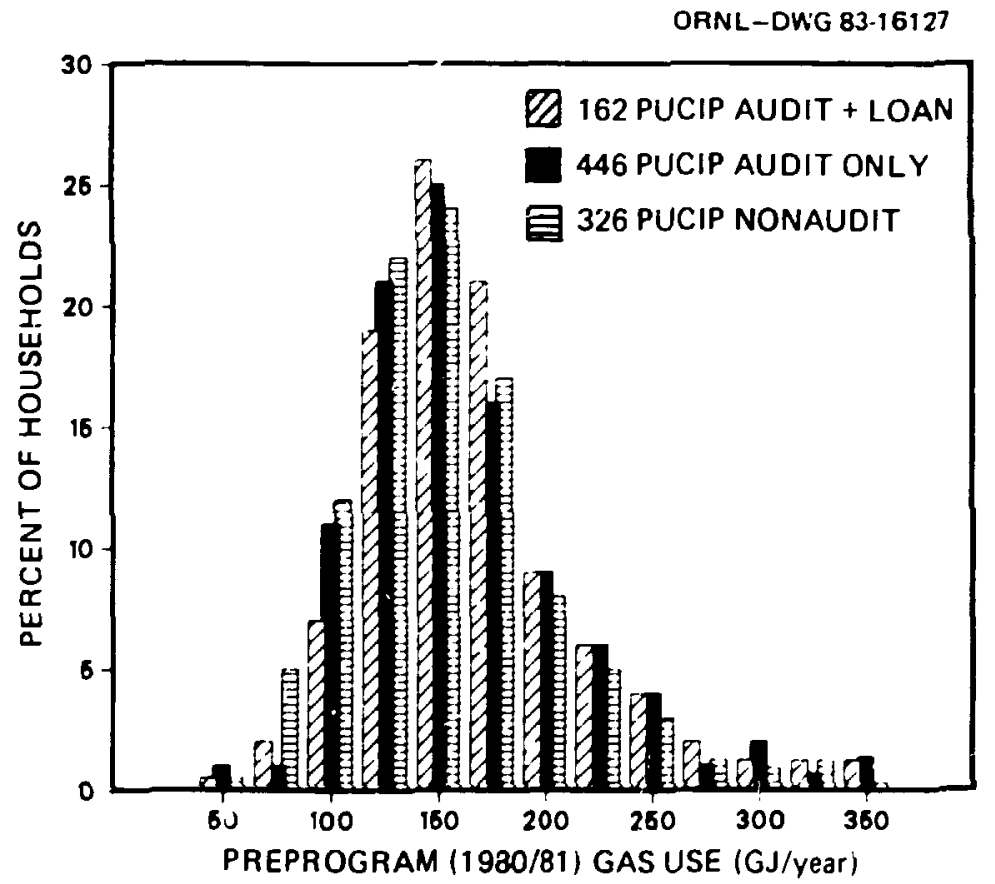

(b)

Fig. 5.1. Hiblograms of preprogram (1980/81) matural gas ue for MECS (a) and PUCTP (b) participants and somparticipants. 
factors that affect consumption, it would not be possible to statistically identify the energy-saving effects of the NSP programs.

We analyzed program energy savings in several ways, using actual natural gas consumption records. Because accurate analysis of gas consumption and conservation is difficult, we developed several approaches (Table 5.1). Such "triangulation" is important in developing estimates that are credible and accurate.

Talle 5.1. Estimates of average anoul antural ges sovice per participant in the NSP resilential enerey conservation programs

\begin{tabular}{|c|c|c|c|c|}
\hline & \multirow{3}{*}{ Model description } & \multicolumn{3}{|c|}{ Annual savir.g (GJ) } \\
\hline & & \multirow{2}{*}{ MECS } & \multicolumn{2}{|c|}{ PUCIP } \\
\hline & & & Loan & Audit ${ }^{\circ}$ \\
\hline 1. & $\begin{array}{l}\text { Normalized annual consumption (NAC) } \\
\text { models for each houschold }\end{array}$ & 5.3 & 23.1 & 6.3 \\
\hline 2. & $\begin{array}{l}\text { Cross-sectional model with } \mathrm{NAC} \text { as } \\
\text { dependent variable }\end{array}$ & 6.3 & 19.1 & \\
\hline$\therefore$ & $\begin{array}{l}\text { Cross-sectional model with } \mathrm{NAC}_{1}-\mathrm{NAC}_{3} \\
\text { as dependent variable }\end{array}$ & 5.6 & 19.0 & \\
\hline
\end{tabular}

oThe incremental savings for PUCIP audit-only households were statistically insignificant for models 2 and 3.

Interestingly, results of the different metiods were surprisingly similar. Overall, the audit program (MECS) yielded a net saving for participants of about $5 \mathrm{GJ} /$ year. The audit-plus-loan program (PUCIP) yielded a net saving for households that received a loan of about $20 \mathrm{GJ} /$ year and a zero net saving for households that received an audit but not a loan. These net savings are those that can be directly attributed to the programs (i.e., net of the savings these households would have achieved without the programs).

The data collected for this evaluation permitted us to address issues other than program performance. For example, we examined the economic attractiveness of measures recommended during the audits and the frequency with which measures were recommended. Ceiling insulation, basement wall insulation, clock thermostats, new heating systems, furnace modification, and caulking/weatherstripping were recommended in more than half the audited homes (Fig. 5.2). However, some measures had very long payback periods and could really be considered suggestions for implementation. For example, because most homes in Minnesota already hao some attic insulation, the average payback period for this measure was about 25 years, hardly attractive to most households. On the other hand, the average payback period for water heater wraps and clock thermostats was about 4 years.

Our evaluation of the BPA Residential Weatherization Pilot Program included enough data to allow us to compare actlial electricity savings with auoit predictions (Fig. 5.3). The median value of the ratio of actual-to-pred.cted savings is 0.66 ; thus, on the average, about two-thirds of the savings predicted during the audit is atually realized in reduced electricity bills. However, the variation around the average is substantial. Actual electricity use increased in more than 10\% of these homes 
ORNL-DWG 83-16122

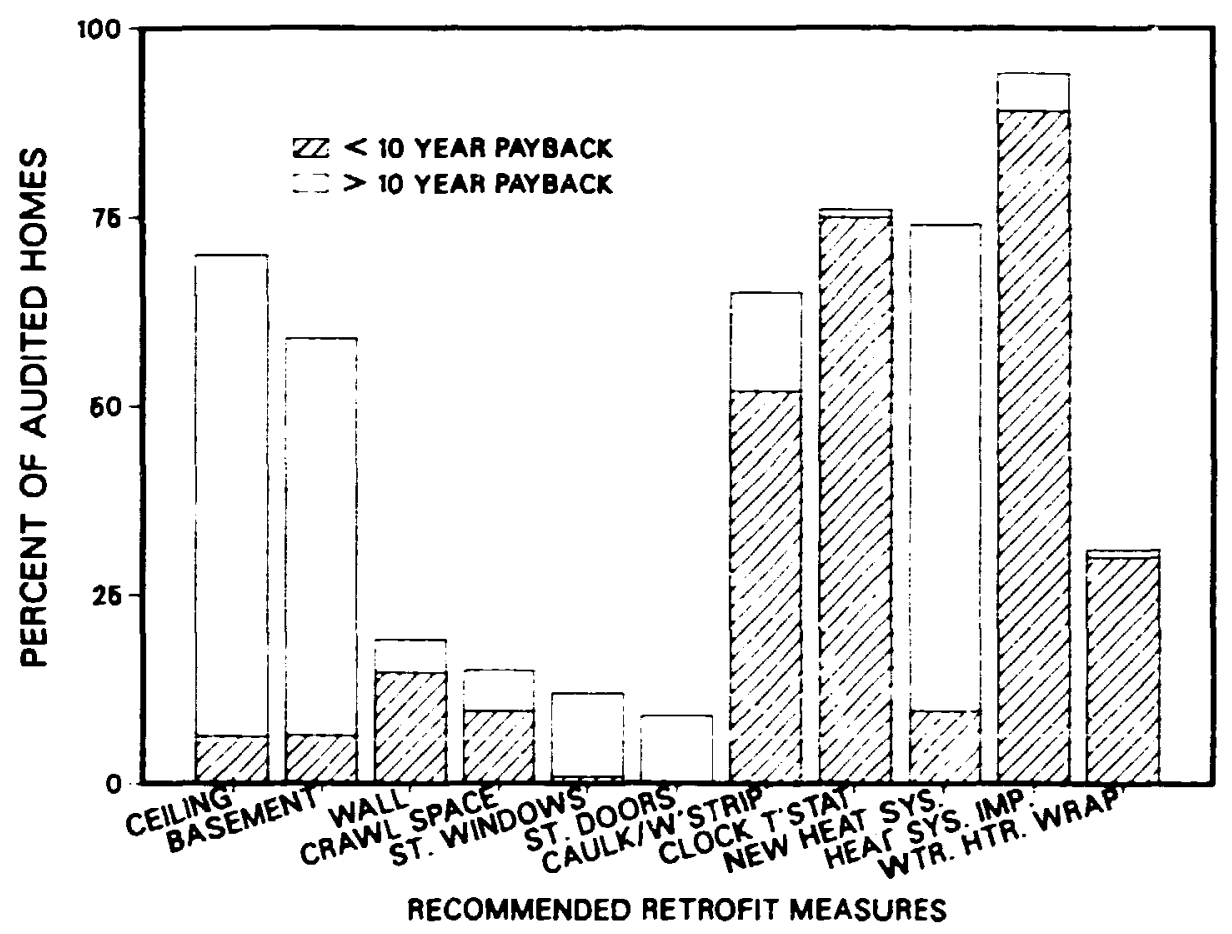

Fig. 5.2. Relative frequeacy with which retrofit measures nere recosameaded during NSP bome energy andits.

OANL-DWG 83-17027

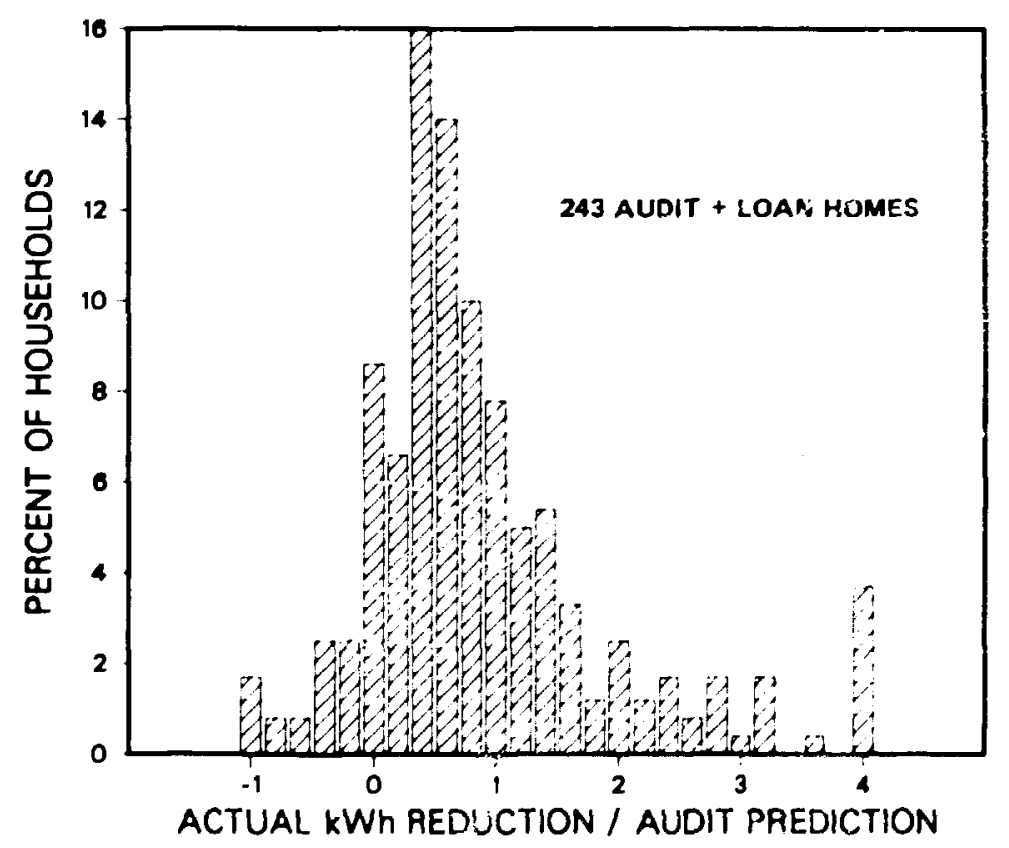

Fig. 5.3. Historam of ratio of actual-to-predicted aimal electricity saring in momes weatmerized ander the BPA pilot program. The bars at the ends include cases with the ratio less than -1 or grea!er than 4 . 
although the audit estimates suggest energy savings. On the other hand, actual savings were more than double the estimated savings in more than $10 \%$ of the hores.

We are using results from RCS prograrn evaluations conducted at ORNL and elsewhere to develop general conclusions concerning RCS performance. Our preliminary findings (additional work will be under way in FY 1984) are as follows:

1. Households who participate in RCS are generally demographically "upscale." Relative to nonparticipants, those who recsive audits tend to have higher incomes, more education, larger homes, and live in single-family homes that they own.

2. In the few cases where careful evaluations were conducted, using actual fuel consumption records, results show small but statistica!ly significant energy savings. Data from Connecticut, Michigan, Minnesota, Wisconsin, Washington, and California suggest an average energy saving for RCS participants of about $5 \mathrm{GJ} /$ year. Long-term savings may be higher because existing analyses used only limited postaudit fuel bills (roughly one year of postaudit data).

3. Although estimates of program energv savings showed some consistency across states and utilities, variation in estimates of program cost-effectiveness is much greater because of the different perspectives from which RCS can be assessed. For example, a New England state might find RCS beneficial because it increases employment within the state and reduces the flow of money from the state to pay for imported fuel; a southwestern state might have an opposite view. Also, assumptions on discount rates and the marginal social costs of fuels saved by RCS strongly affect results.

\subsubsection{Alterante Fuels Information Requirements Review}

The purpose of this study was to determine the information needed to attain or pursue natienal goals that pertain to renewable, energy resources. Five renewable energy (or "alternate fuels") topics were covered in this study [subtopics or emphases are given in brackets]: (1) solar [production and sales of therm.al collectors and photovoltaics; installation of active and passive systrms]; (2) biomass [energy from wood. industrial and electric power utilization, wood fuel consumption in hornes and in commercial buildings, manufacture of wood-burning equipment; energy from organic, mainly urban, wastes; production of alcohol fuels from biomass feedstocks]; (3) wind [conversion to electricity, mainly at "wind farms"]; (4) geothernal [eleccric power generation; direct-heat applications]; (5) small-scale (30-MW) hydro [emphasis on small, electric power facilities, especially at low-head sites].

Eight national goals were identified in the gt:dy as requiring senewable energy information. These goals were related to

1. developing and using renewable energy resources;

2. systematic national energy planning;

3. predicting $\mathrm{re}_{\boldsymbol{\gamma}}$,ional and state economic impacts of changing patterns of energy supply; consumption, and prices;

4. improving the quality of private-sector decisions;

5. protecting the environment;

6. fostering competition in renewable energy industries; 
7. promoting the nation's international leadership in renewable energy technologies; and

8. supporting an agency's missions and functions (c.g., providing information to the Treasury Department to assist in their evaluation o' the effectiveness of solar tax crodits).

The national goals, a major methodological theme of the study, were used for three important purposes: selection of user organizations, communication with individual users, and contribution to evaluating the benefits of obtainirg needed information.

Priorities for collecting needed information were derived through an analysis of benefits and costs. For each information item, a nonmonetary measure of benefit was calculated from ise number of goals $(n)$ associated with the item, the user-rated importance $\left(I_{i}\right)$ of the item needed for the specific national goal $(i)$, and the "weight" $\left(G_{i}\right)$-or quantified judgment of the relative importance - of goal $i$. The following equation was used in scoring benefits:

$$
B=\sum_{i=1}^{\infty} G_{i} I_{i}
$$

Relative costs (termed a "cost index") were estimated for each information item from three factors: (a) the level of accuracy desired by most users, (b) the size of the respondent population, and (c) the degree of difficulty that respondents would likely face in providing the item.

Major conclusions were reached from priority rankings based pimarily on benefit scores and secondarily on cost considerations. Frem benefit scores averaged fr: all items within each of the five energy topies, it was found that biomass and solar information ranked highest, small hydro and wird ranked intermediate, and geothermal ranked lowest. Similar, but more detaited, analysis of benefit scores for solar items showed that solar equipment production and sales ranked equally with active- and passive-solar installations; however, the latter (i.e., installations) is more costly information to obtain. Among bionass energy subtopics, information on national-level energy supply and consumption ranked highest, followed by information on large-scale energy from wood fuel. Fo: small-scale hydro, wind energy, and geothermal, the highest priority items included amount and cost of electric energy produced.

Recommendations were made to EIA based on the major conclusions discussed above. For obtaining biomass energy information, the leading recommendation was to develop estimates of national level supply and consumption by means of an analytic study; two other recommendations were to develop forms to survey fo: industrial utilization of wood fuel and for production of alcohol from biomass. For solar energy, the leading - -commendations centered around modifying a present form (EIA-63) used for collecting data on the production and sales of collectors and photovo'taics: more costly recommendations pertained to developing a form to collect information from homebuilders on active and passive solar installations. For small-sesle hydro and wind energy, the recommendations were to increase the respondent populations of existing electric power forms to include wind farms and nonutility.owned small hydre facilitiss. For geothermal energy information, no action was recommended other than continuing the present collec:ion of electric power data.

\subsubsection{Nuclear Information Requirements Reriew}

The nuclear information requirements review is a determination of EIA data needs pertaining to the nuclear power industry. The Data Methods Group and staff from the Enginecring 
Technology Division undertook the completion of the project after an unsucessful attempt by a subcontractor.

Seven major topics were considered in this study: (1) uranium supply (covering reserves and resources, exploration, the mining and milling industry, marketing, and utilities as uranium purchasers), (2) conversion of $\mathrm{U}_{3} \mathrm{O}_{2}$ to $\mathrm{UF}_{6}$, (3) enrichment, (4) fuel fabrication, (5) nuclear power plaris, (6) spent fuel storage, and (7) waste management.

In investigating data required by federal users, the principal steps of the study were

1. developing an itemized chosklist, structured according to the seven major topics;

2. selecting a set of federal data users and querying them on their data needs via a questionnaire based on the structured checklist;

3. developing and implementing procedures for ranking the benefits of obtaining each needed data item;

4. using benefits ranking and other considerations to classify each item as either "required" or "not required";

5. determining which of the items are either collected by periodic federal survey forms or are otherwise made available to the user community;

6. developing recoinmendations for EIA's consideration concerning the required data; and

7. estimating both cost to the government and burden to survey respondents for each group of related data recommended for collection or acquisition.

This study will not be completed until the second quarter of FY 1584. However, preliminary findings have showin that the topics of highest priority are uranium suppl $\because$, spent fuel storage, operating nuclear power plants, and nuclear power plant construction. For each of these topics, data items on the checklist that ranked very high in benefits will be studied and identified for collection by the government. At this stage of the study, some of the data presently identified as being required include domestic uranium reserves, potential uranium resources, domestic mine output, domestic concentrate production, price data, uraniuin inventories, and projecied uranium requirements. Virtually all tnese data items are also needed for a study discussed in another section (see Sect. 4.1.1) entitled "Uranium Industry Analysis Program." Sorne of these data are presently obtained via form EIA-491, "Survey of United States Uranium Marketing Activity." Additionally, preliminary results show that data on three nuclear fue: topics (conversion of $\mathrm{U}_{3} \mathrm{O}_{8}$ to $\mathrm{UF}_{6}$, fabrication of nuclear fuel, and enrichment) require no immediate data collection activities by EIA. Further results are yet to be determined and will be reported in the next annual report.

\subsubsection{Petroleum Supply Interruption Studies}

For the Economics and Statistics Division of the EIA Office of Energy Markets and End Use, ORNL, conducted studies relevant to EIA's responsibility for providing information to support decision makers in the event of an energy supply disruption. ORNL, demonstrated techniques to

- Analyze domestic petroleum ref.ning operations en a monthly regional basis.

- Analyıe consumption of refines petroleum products on a monthly reginnal basis. 
- Construct data systems that support analytical tools.

- Arsist decision makers in the event of an energy supply disruption.

Domestic petroleum operations were analyzed with the refinery linear programming model of Tumer, Mason, and Associates (TMA). The TMA model permits manipulation of a large number of variabies that deszribe

- constraints and custs ielated to operation of physical plants,

- crude oil supplies, assays, and costs, and

- demands, prices, and detailed physical property specifications for refined petroleum products.

ORNL, updated the TMA model and validated model performance for the most recent year of operating data. Figure 5.4 illustrates use of the TMA model to gauge the sensitivity of PAD II' refineries to 1981 reductions in crude oil supply. A refinery's production response can be summarized quantitatively as a refinery input or crude oil supply elasticity of production. This elasticity is the percentage change in production associated with a $1 \%$ change in inputs. For motor gasoline in the scenario of Fig. 5.4, this elasticity is less than unity (0.77). For distillate fuel oil, jet

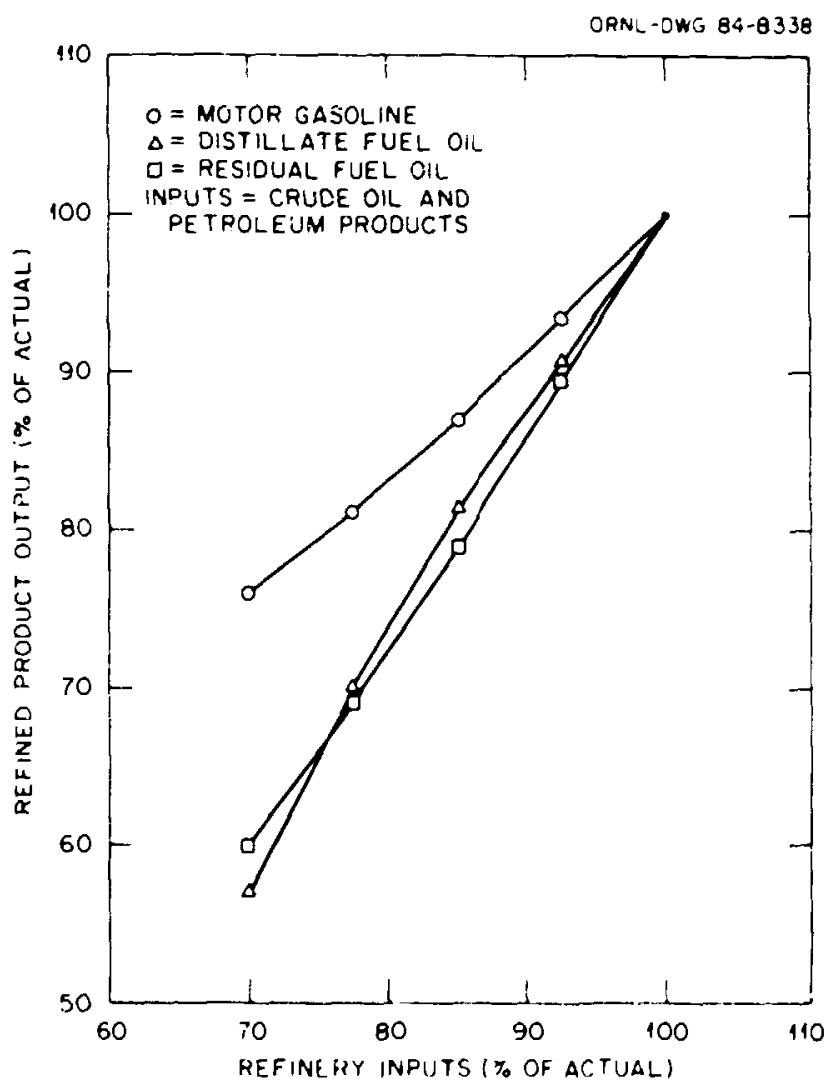

Fig. 7.4 . Refined product sensitivity to refinery iaputs.

PAD II = Petroleum Administration for Defense District II, which includes these states: North Dakota, South Dakota, Kansas, Tennessee, Oklahoma, Kentucky, Ohio, Wisconsin, Minnesota, Michigan, Indiana. Illinois, Nebraska, Jowa, and Missouri. 
fue!, kerosene, and residual fuel oil, the elasticity is greater than unity (1.45 or greater). These elasticities indicate that, as refinery inputs are decreased from a base-case level, conversion to the higher-values motor gasoline product is favored.

ORNL analyzed regional consumption of refined petroleum products with multiple-variable Box-Jenkins techniques. ORNL constructed 7 product price models, 5 personal income models, 5 population models, 5 heating degree-day models, and 35 consumption models. Each consumption model provided estimates of price, income, population, and heating degree-day short-term elasticities of consumption. Forecasts and confidence limits were tabulated, regional shares of consumption were estimated, and graphical displays such as Fig. 5.5 were produced. The inset equation of Fig. 5.5 relates the month ' $t$ ' regional consumption of No. 2 ieating oil $\left(C_{b}\right.$, in metric

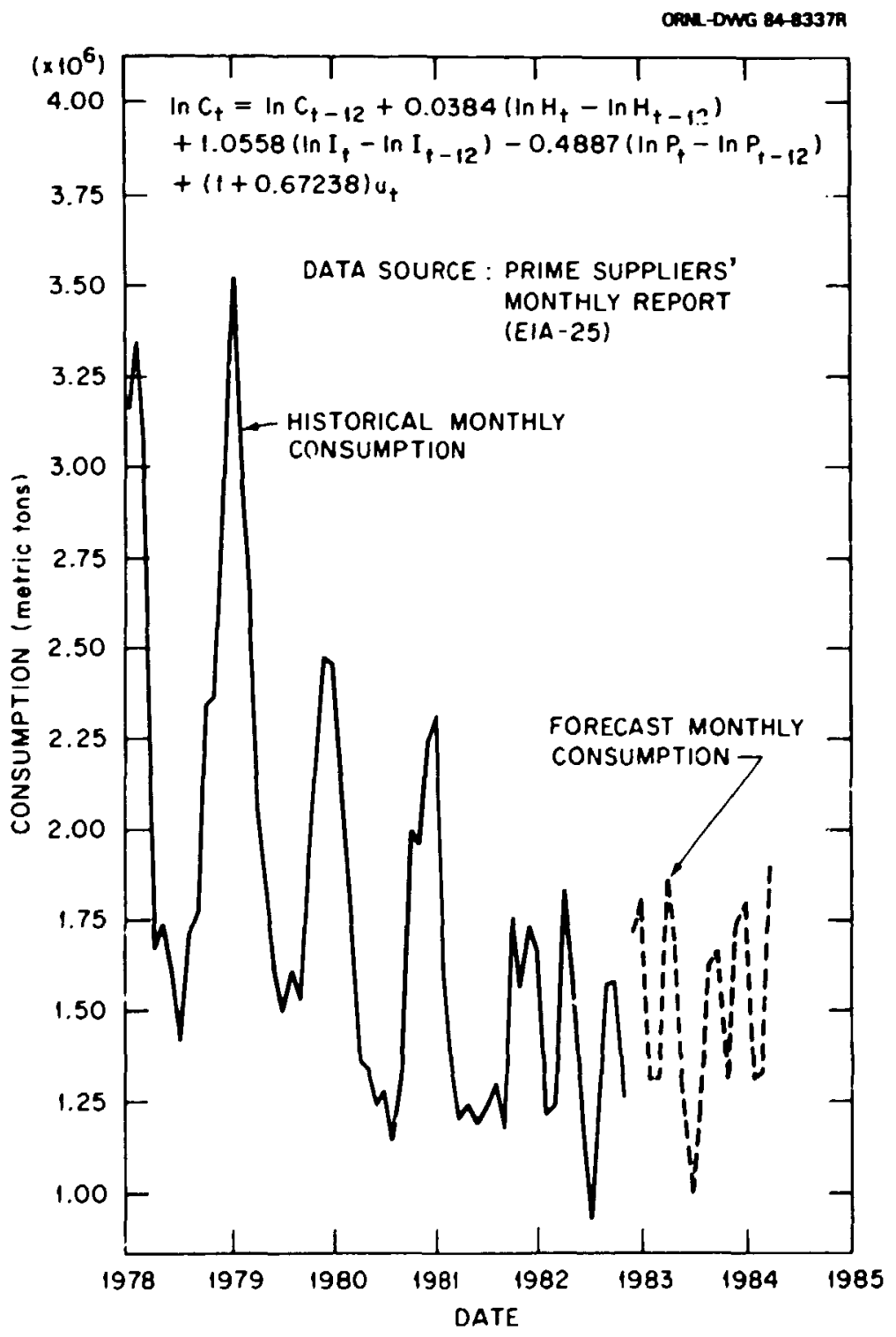

Fig. 5.5. PAD II comemption of No. 2 heating ofl. 
tons) to lagged consumption $\left(C_{t-12}\right)$; to regional population-weighted heating degree-days $\left(H_{t}\right.$ and $\left.H_{t-12}\right)$; to regional total personal income in millions of 1980 dollars $\left(I_{t}\right.$ and $\left.I_{t-12}\right)$; to the national price of No. 2 heating oil in cents per gallon converted to 1980 prices $\left(P_{1}\right.$ and $\left.P_{1-12}\right)$; and to a random shock entering the model $\left(u_{t}\right)$.

\subsubsection{Major Item System Mapping (MISM) Project for the U.S. Army Materiel Developanent and Readiness Command}

The U.S. Army Materiel Development and Readiness Command (DARCOM) is the major a mmand responsible for the development, deployment, and management of Army equipment and mite iel. In the past, this function has been managed by developers responsible for a specific major iter.1, but this practice has led to unknown amounts of duplication of inventories. Thus a unified data management/decision-support system is needed. Some examples of major items would be the M1 tank, an attack helicopter, a training device used to train tank drivers, a testing device used to tesi and repair an automatic loading system, or a generator required to run test equipment. DARCOM is now moving to a system concept that will result in better equipment management because all hardware relationships of all components of all major items would be known and managed in an integrated and automated data system. These relationships will be portrayed in computer-generated maps supported by this sophisticated data base management system. The definition, development, testing, and implementation of major item system maps are the subject and goal of this project.

Figure 5.6 is an example of a simplified version of une major item system map; it maps the attack helicopter: TOW [tube launched, optically (tracked), wire guided] missile system. Figure 5.7 is an expansion of one of its ma;or items, a 7.62-mm machine gun (shown in Fig. 5.6). This inset is provided to show the nesting and detail of retrieval required in this decision-support system and data base management system (DBMS). The item relationships that are to be available to this decision-support system are to be managed in a DBMS environment termed the MIS.M Data Base (MISM DB). It is estimated that there are 1,500 to $2,500 \mathrm{major}$ item systems to be mapped, 10,000 items that would fit into the major item system maps in various ways, and 62 data elements that must be entered for each major item and/or major item sysiem.

This project primarily represents a knowledge acquisition/knowledge representation research problem because, among other things, the information has never been available in one location and must be integrated into a co.nprehensive and flexible decision-support system that can be used by Army management for strategic planning purposes.

The major requirement of this project is for the ORNL computer model to prove the concept of MISM and to provide a capability to support interactive MISM DB access. This access will support the analysis of MISM information by a number of Army managers for a variety of purposes.

The MISM project is a complex decision-support system development effort that is a key segment of the Army's overall project to modernize [the Army Materiel Plan (AMP MOD)]. Some of the objectives of the AMP MOD include

1. The capability to automate the preparation, analysis, and computer- assisted defense of budgetary requirements for DARCOM and Army Headquarters. 


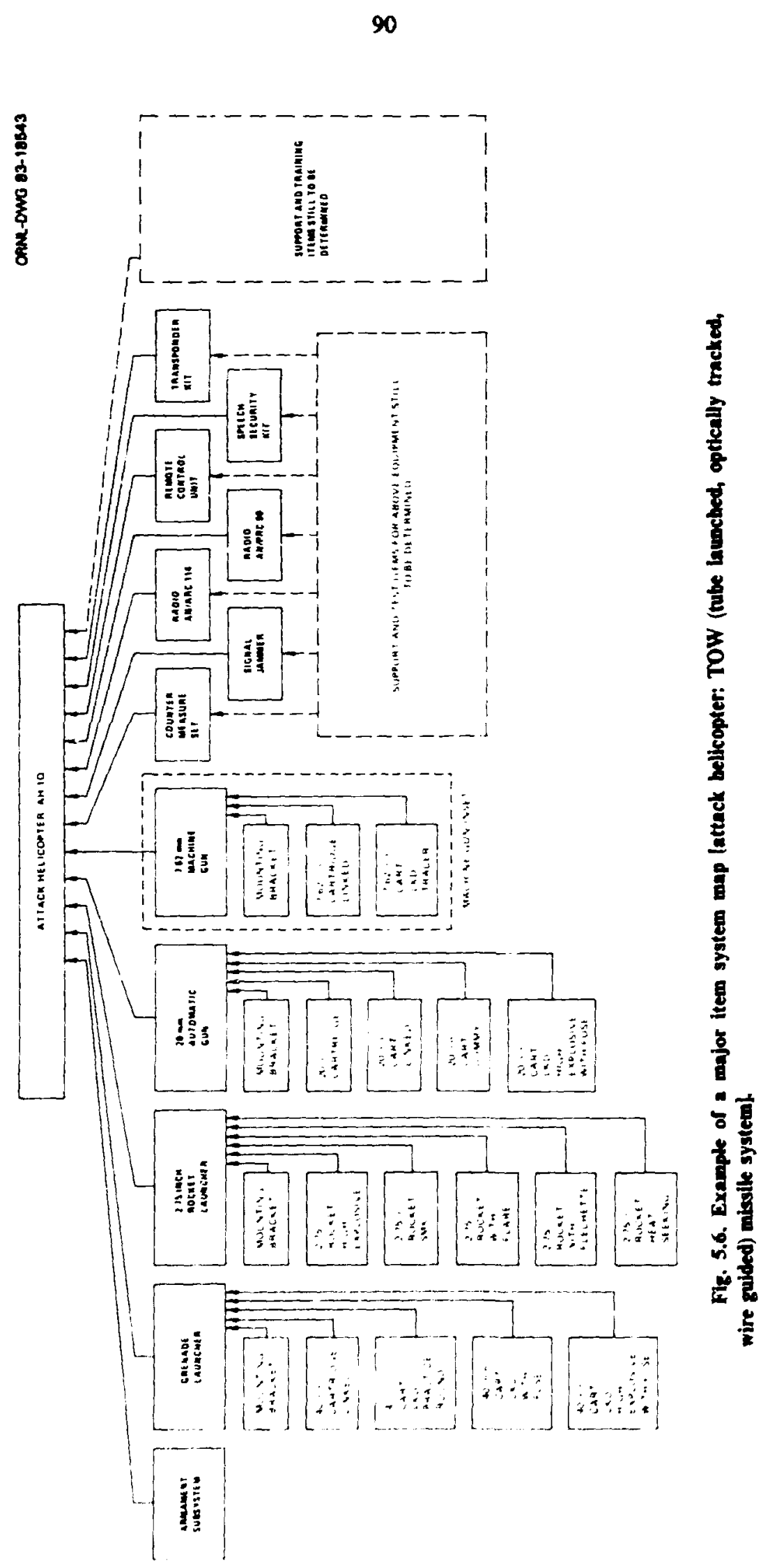


ORNL-DWG B3 18542

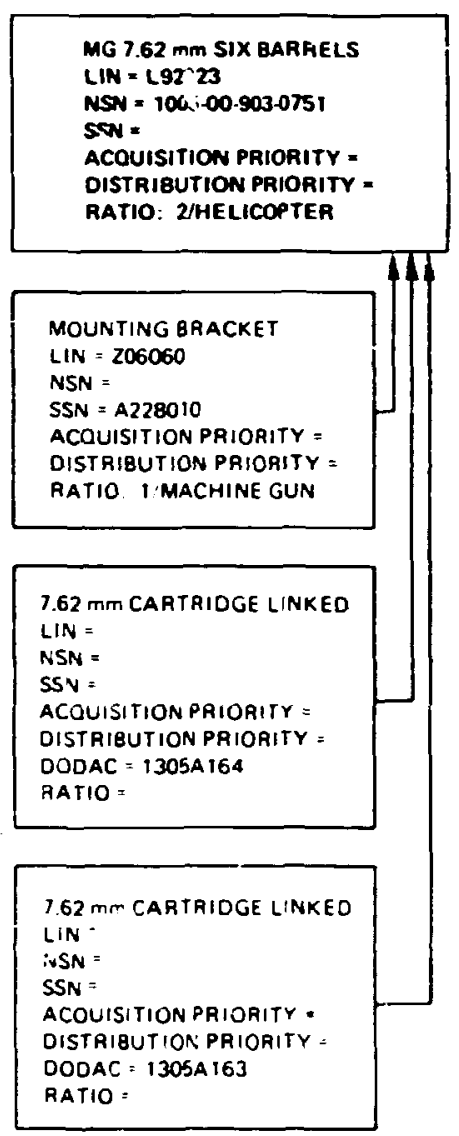

Fig. 5.7. As expansion of the 7.62-nen machine gen dat: shown in Fig. 5.6.

2. The ability to balance programs to ensure that all prime major items, component major items, and support major items are part of the budget process and are properly increased or decreased as changes in the major item systems are affected by budget changes.

DAS has made significant progress in resolving the technicai problems associated with this project. The research issues of data base design and modeling, decision-support system methods, knowledgu representation, knowledge acquisition, etr., are also being addressed. This progress is documented in the "Capabilities Briefing"13 and "Requirements Formulation"14 Jocuments. Both documents describe the ORNL recommended data schema, the manual or automated method for collection of the data elements, and the necessary reporting formats. These items must be fully defined by DAS before the implementation process can proceed. DAS will produce a complete specification document that will be used as a detailed source document for system devclopers and Army implementation teams

\subsubsection{Aircrew Automated Escape Systems}

DAS is working with the Naval Weapons Engineering Systems Activity (NAVWFSA) to support the Navy's pilot safety program. This safety program includes, for exumple, analyses of jet 
aircraft maintenance procedures and aircrew automated cocape systems. One tool for studying the effectiveneas of airreer automated escape systems is computer simulation. Previously, the U.S. Navy had contracted with private industry to develop aircres escape systems simulation software. This software was named the General Escape System Simulation (GESS). It was later modified and housed at the Naval Air Development Center. Prior to ORNL's participation, the software was written in FORTRAN for use with Contr 1 Data Corporation hardware and was used primarily to calibrate and set up ejection system sted tests. (It was not specifically designed to evaluate aircrew safety factors.)

As with any complex system, successful simulation of the ejection system requires that each subsystem be thoroughly understood and modeled at the appropriate level of complexity, an overly complex code becomes unwieldy and unusable, whereas an overiy simplified code fails to simulate the phenomena of interest. DAS is significantly assisting NAVWESA in the development and understanding of the code, the individual subsystems, and the interaction of the subsystems. To this effect, DAS has (1) documented the code, (2) transcribed the code for use with IBM-compatible hardware, (3) identified and corrected various coding errors, (4) identified and suggested modifications for the purpose of rendering a more faithful simulation, (5) provided and documented an understanding of the relationship between the code and events actually occurring during pilot ejection from an aircraft (phenomena), and (6) investigated the limits and sensitivities of the code. Validation has been done in the following five steps:

1. Are ihe equations and coding correct?

2. For phenomena that can be theoretically calculated, do the theoretical calculations and simulatio: agree?

3. Dn the simulations generally agree with other simulation models of this genre?

4. For observed ejections under controlled conditions, do the simulations agree with the observations?

5. When the code is run with input representing extreme conditions, does the code behave in a stable manner, or are there numerical instabilities?

Although in many ways this project represents a departure from previous DAS commitments, it can be ansidered to be an adjunct of model development validation and work-previously undertaken fo: EIA - and is hoped to dovetail with the DAS system R\&D program insofar as a long-range project goal is to develop an expert system for accident unvestigation and design specification. Thus the full development of this tool for pilot safety requires the application of many artificial intelligence techniques; the ejection process involves complex interactions and occurs under such a variety of conditions that automated analysis techniques are necessitated and appropriate research pursued.

\subsubsection{Project to Enhance the Acceasibility and Arallablity of the Loriatics Intellizence File for the \\ U.S. Army I ogiatics Control Activity}

The Department of the Army (DA) Logstics Control Activity (LCA) maintains a large and complex data base containing logistics information for the Army. Because the information demands 
and transaction loads on this data base [known as the Logistics Intelligenai File (LIF)] are large dynamic, and subject to growth in large increments, current third-generation data management and hardware will become obsolete very quickly. Fourth-generation principles for data management and access must be studied to provide for replacement of the present data processing system with one that can be readily adapted to changing demands.

The LIF exists for the purposes of

- Maintaining visib:lity of the logistics pipeline for support of Army activities worddride.

- Providing recurring exception reports to all levels within the Army on the efficiency of the supply and distribution system.

- Analyzing logistics system performance.

- Responding to emergency needs of DA and DOD.

The LCA data processing system currently uses technology developed more than ten years ago, and it is now unable to cope with many new demands placed upon it. The system currently handles more than 200,000 transactions per day and maintains a data base of more than $20,000,000$ records. Army plans envision as much as tenfold growth in the size of the data base, and transaction volumes could increase by $100 \%$. Processing this volume of data efficiently will exceed the design capacity of all known third-generation technology. Thus, R\&D at the state of the ant with commercial sector and high-technology componen's is a critical part of the success of this project.

After initial study of the LCA information processing system, DAS personnel have formulated a plan whereby state-of-the-art methodology in data management systems, operating software, and computer processors can be configured, tested, and installed to provide LCA with a highly flexible information processing system and can do so with minimal impact on ongoing operations.

The ORNL conceptual design incorporates the technotogy of multiple, parallel, minicomputer processors for high-volume, fault-tolerant transaction processing together with an integrated, relational type of "fourth-gereration" DBMS for ease of date access and flexibility in meeting new processing demands. The proposed system has a modular, incrementally expandable design such that it can be initiated and tested on a small scale and then be expanded in stages to meet all foresecable processing demands.

The conversion plan ${ }^{15}$ for the LCA transition to the new system, as developed by ORNL, was the subject of presentations to the LCA staff ${ }^{16}$ and to the staff of the U.S. Amiy Headquarters Materiel Development and Readiness Command (DARCOM). ${ }^{17}$

Following acceptance of the conceptual design and work plan by the Army, DAS staff reviewed the state of the art in commercially available parallel-proceasing systems. We then developed a full technical specification covering both the performance requirements and the technological characteristics to be satisfied by the planned system, to meet the needs of the LCA. The next step will be to prototype a fully configured, compatible system in order to provide DA with a pron-of-concept and benchmark. This prototype will then serve to assist in full implementation but will, more importantly, serve as a nucleus of a design, development, and teat facility for fourth-generation data systems R\&D related to the massive needs of DARCOM and DA logistics information management, access, and retrieval for analysis and asessment. 


\subsection{RESEARCH UTHLIZATION}

\subsubsection{Erabation Grom}

The methods used and results developed by the Evaluation Grocp are of value to many organizations in addition to our program sponsors. Members of the group presented invited papers at conferences sponsored by the New York Public Service Commission, the National Governors Association, the Southeast. Electric Exchange, the Edison Electric Institute, the Electric Power Research Institute, and the Alliance to Save Energy. In addition, our work was presented in formal and informal seminars to our program sponsors (DOE and BPA), Princeton University, and the International Association of Energy Economists.

We receive many requests for copies of our ORNL reports and papers from individuals in the federal government, state government (both state energy of ives and public service commissions), electric and gas utilities, universities, ard other private research and consulting firms.

At the request of the House Subcommittee on Energy Conservation and Power, we reviewed a report un conservation program evaluation. We also participate in a National Research Council Panel on Energy Demand Analysis.

Finally, we receive many phone calls from people interested in discussing our work and its applicability to other organizations and situations.

\subsubsection{Systems Analysis Grom}

The Oak Ridge Industrial Model (ORIM) was originally developed in 1979-1980 for the DOE EIA as a tool for projecting industrial fuel demands. In the past year, ORNL has responded to several requests from non-DOE organizations for information derived from ORIM or for use of the model. These requests included the following:

1. Standard Oil Company of Ohio-ORIM forecasts of manufacturing-sector energy purchases; guidance on life-cycle costs of energy-converting capital stocks and costs of operation and maintenance.

2. Center for Energy Studies, University of Texas-Guidance on estimation of vintage distribution of energy-converting capital stocks in Texas; estimation of shares of factozs of production in Texas (i.e., capital, labor, materials, steam, heat, drive, and electrical energy services); and calibration of ORIM to represent the impact of nonprice factors on fuel and investment choices (e.g., expectations related to future environmental control legislation).

3. Department of Energy, State of New Jersey-ORIM forecasts of manufacturing-sector energy purchase in Federal Region II for the 1975-2000 period.

4. Wisconsin Livision of State Energy-ORIM forecasts of manufacturing-sector energy purchases.

5. Department of Chemical Engineering, University of Tennessee-URIM analysis of middle- and high-level oil price impacts on the consumption of natural gas and other fuels in Federal Region IV over the next 17 years. 


$$
95 / 96
$$

\section{S.4 REFERENCES}

1. E. Hirst et al., Evaluation of the BrA Residential Weatherization Pilot Program, ORNL/CON-124, Oak Ridge National Laboratory, June $19,03$.

2. D. I. Lerman, B. H. Bronfman, and B. E Tonn, Process Evaluation of the Bonneville Power Administration Reridential Weatherization Pilot Program, ORNL/CON-138, Oal Ridge National Laboratory, October 1983.

3. L. F. Menendez, The Residential Cossermation Service in Comnecticut: A Profile of CONN SAVE, ORNL/CON-I 36, Oat Ridge Natioaal Laboratory, June IS83.

4. E. Hirst and P. S. Hu, The Residential Conservation Service in Comecticut: Evaluation of the CONN SAVE Program, ORNI,/CON-132, Oak Ridge National Laboratory, September 1983.

5. B. Tonn, Selection of States for Evalwation of the Residential Consenvation Service, ORNL/CON-139, Oak Ridge Mational Laboratory. November 1983.

6. L. G. Berry, The Role of Financiai Incentives in Utility-Sponsored Residential Conservation Prograns: A Review of Customer Surveys, ORNL/CON-102, Oak Kidee Nationd Laboratory, December 1983.

7. L Berry, H. Tsao, and E Hirst, Design Options to Test the Effects of Financial Incentives in a Utility Consenvation Program TVA's Heat Pump Water Heater Program ORNL/CON-125, Oak Ridge National Laboratory, August 1983.

8. E Hirst et al., Methods to Deul with Self Selection in Estimating Conservation Program Energy Savings: Use of Symhetic Data to Test Alternative Approaches, ORNL/CON-120, Oak Ridge Natioal Laboratory, March 1983.

9. E Hirst, D. White, and R. Goeltz, Comparison of Astual Electricity Sovings with Audit Predictions in the BPA Residential Weatherization Pilot Program, ORNL/CON-142, Oak Ridge Natioaal Laboratory, November 1983.

10. E. Hirst and R. Goeltz, Comparison of Actual and Predicted Energy Savings in Minnesota Gas-Heated Single-Family Homes, ORNL/CON-147, Oak Ridge Vational Leboratory, March 1984.

11. E. Hirst et al., "Recent Changes in U.S. Energy Consumption: What Happened and Why," Annual Review of Energy 8, 193-245 (1983).

12. E. Hirst and R. Goeltz, Evaluation of Home Energy Audit and Retrofit Loan Programs in Minnesota: The Nonhern States Pomer Experience, ORNL/CON-136, Onk Ridge National Laboratory, December 1983.

13. P. Y. Bengtson and G. R. Hadder, Capabilities Briefing Subtask I.C of the Major Item System Mapping (MISM) Project (Drafi), prepared by Oak Ridge National Laboratory, rresented to the MISM Functional Working Group, Dec. 15, 1983.

14. P. Y. Bengtson et al., Requiremenss Formulation Subtask I.A of the Major Item System Mapping (MISM) Project (Draft), prepared by Oak Ridge National Laboratory, submitted tc Cliff Nelson, DARCOM, Alexandria, Va., Jan. 2, 1984.

15. A. S. Loebl and R. W. Barnes, Project Plan 10 Enhance the Accessibility and Availability of the LIF fn the LCA (PAAL), prepared by Oak Ridge National Laboratory for the U.S. Amy Logistics Control Acivity, Mat. 9, 1983.

16. A. S. Loebl and R. W. Barnes, -Project Plan to Enhance the Accensibility and Availability of the LIF for the LCA," briefing prepared by Oak Ridge National Laborgtcry, presented to the staff of the US. Army Logistics Control Activity, San Francisco, Calif., Mar. 9, 1983.

17. A. S. Loebl and R. W. Barnes, "Project Plan to Enhance the Accessibility bud Availability of the LIF for LCA (PAAL)," briefing prepared by Oak Ridge National Latoratory, presented to the saff of the U.S. Army Headquarters Materiel Development and Readineas Command, Washington, D.C., May 3, 1983. 


\title{
6. Efficiency and Renewables Research Section
}

\author{
J. W. Michel" \\ W. R. Mixon ${ }^{\dagger}$
}

\subsection{INTRODUCTION}

\subsubsection{Section Orerview}

This chapter is divided into two main sections; Sect. 6.1 summarizes the six major areas of activity of the section, and Sect. 6.2 contains selected, brief technical highlights of each activity.

The work of the section continued to be focused on technology aspects of energy conservation through research on efficiency improvements. The principal sponsor is the U.S. Department of Energy (DOE) Office of Corservation and Renewable Energy. Work on renewable energy sources-geothermal and solar-has continued to decrease and during this past year was combined organizationally with the work on industrial/chemical heat pumps. Work for other government agencies increased, with several conservation-related projects for the U.S. Army, Navy, and Air Force being started. The largest program, Building Equipment Research, continued with diverse heating, ventilating, and air-conditioning (HVAC) projects, both electric and fossil-fuel powered, but with possibilities fer a significant efficiency improvewy ent in gas-fired absorption cycle heat pumps. Plans for a large-scale distribution automation and load management experiment to be conducted on the Athens Utilities Board system in Athens, Tennessee, in cooperation with the Tennessee Valley Authority, are proceeding on schedule as part of the Power Systems Technology Program. Also as part of this program, a project to assess the effects of an eirctromagnetic nuclear pulse from a nuclear explosion on the U.S. electric energy systems was begun.

Considerable effort was devoted to pregram planning activities and research utilization, the latter through many subcontracts to industry and through special conferences and workshops.

\footnotetext{
Section Head.

'Manager for X-10 groups.
} 


\subsubsection{Bailing Equipmeat Research Program}

R. E. Minturn

\begin{tabular}{|c|c|c|c|}
\hline V. D. Baxter & R. C. DeVault & v. O. Haynest & R. W. Murphy \\
\hline J. L. Bledone' & N. Domingo" & K. E. Heidenreich & E A. Nephew \\
\hline F. C. Chent & R. D. Ellison & W. L. Jackson' & H. Perez-Blanco \\
\hline N. C. J. Cben & C. J. Emerson" & W. P. Levins & G. T. Privos" \\
\hline J. E Christian & P. D. Fairchild ${ }^{\ddagger}$ & R. N. McGill & C. K. Rice \\
\hline G. L. Copeland' & S. K. Fischer & V. C. Mei & E A Vineyand \\
\hline F. A. Creswick ${ }^{\ddagger}$ & F. P. Griftin & W. A. Miller & F. J. Weaver' \\
\hline J. L. Crowley & G. Grossman" & J. C. Moyers' & C.D. West \\
\hline
\end{tabular}

The Building Equipment Research Prograrn, sponsored by the DOE Office of Conservation and Renewable Energy, has the objective of developing technological concepes that will increase the efficiency of building equipment, with emphasis on equipment used for heating, cooling. and providing hot water to residential and commercial buildings. The program can be classified lossely into three major activity areas: (1) electrically driven systems, (2) beat-actuated systems, and (3) alternate and common systems. In each area, both analytical and experissental research is conducted, and an attempt is made to provide a reasonable balance between subcontracted and inhouse work that emphasizes long-range, bigh-risk, generic projects. Significant support for this program is obtained from other Oak Ridge National Laboratory (ORNL) divisions, particularly the Engineering Technology, Metals and Ceramics, and Computer Sciences divisions.

Electrically driven systems. The primary concerns of this area are vapor compression heat pump systems and major electric appliances, although the emphasis on the latter has decreased appreciably from former years. There are five subareas, as follows:

1. Capacity modulation of simr rnmnression systems (see Sect. 6.2);

2. research on dynamic losses in heat pump operation;

3. development of analytical design tools for heat pumps;

4. ronazeotropic refrigerant mixture research; and

5. development of ground-coupled heat pump technology.

During this report period, considerable effort was made to establish a continuing liaison between ORNL asd the heat pump industry so that the DOE-sponsored researsh would neither be duplicative of, nor competitive with, that being done in the private sector. Most of the major heat

\footnotetext{
'Program Manager.

'Computer Sciences Division.

Group Leader.

Engineering Technology Division.

'Metals and Ceramics Division.

"Consultant, Technion-Israel Institute of Technology, Haifa, Istael.
} 
primp and compressor manufocturers as well as several of the smaller ones were visited, and the beginning of a working, cooperative relationship was established with several manufacturers.

Heat-actuated systems. This research seeks to develop more efficient means to use gas and oil for tuilding heating and cooling and water heating through the use of advanced heat pump systems. The following three subareas have been identified:

1. development of absorption heat pump technology (see Sect. 6.2);

2. development of free-piston Stirling-engine-driven heat pump technology, and

3. development of IC-engine-driven heat pump technology.

The work in absorption heat pump technology is focused on the identificatioal and development of advanced cycle concepts that hold promise for making this technology economically viable, and a possible "breakthrough" is described in Sect. 6.2. Our work in Stirling-driven vapor compression systems is largely a subcontracted effort and has been limited to consideration of the compressor and its coupling to the engine; we have not been involved in engine development itself. A hydraulic coupling system under development by Mechanical Technology, Inc., has recently shown promising signs of success. An in-house analytial effort has been useful in identifying the capabilities and shortcomings of existing Stirling engine models and has developed a useful simplified computer model. Work in the third subarea is directed at developing concepts that might make possible lowcost, reliable, and durable internal-combustion-engine-driven heat pump systems. This work is concentrated on the use of an advanced linear engine with a bellows seal connection to a compressor. The bellows seal has been successfully demonstrated, but problems remain in matching the engine and compressor performance characteristics for high overall efficiency.

Alternate and common systems. Work in this program area involves projects that are common to bo:h electric and gas-driven systems as well as projects designed to identify new opportunities for building equipment research. The six subareas are as follows:

1. identification and evaiuation of novel refrigeration cycle concepts;

2. Stirling cycle heat pump evaluation and development (see Sect. 6.2);

3. development of advanced heating and cooling distribution system technology;

4. acvelopment of advanced HVAC concepts for commercial buildings;

5. testing and evaluation of building equipment performance in the field; and

6. development of advanced insulation for buildings equipment.

The scope of each of these subareas is defined quite well by its title. The principal objective of the project on the Stirling cycle heat pump is the development of a heat pump with superior performance at low ambient temperatures. The results to date in this area are described in more detail in Sect. 6.2.

In addition to the work in the three areas just described, we maintain an ongoing effort to evaluate research projects and technologies to ensure that our efforts have a good chance of eventually making a favorable impact on national energy use. We also survey related work occurring in foreign countries and cooperate with a number of these countries, through the Iniernational Energy Agency, in heat-pump-related research and information transfer. 


\title{
6.1.3 Indastrial/Chemical Heat Pemps
}

\author{
S. I. Kaplan* \\ G. Grossman ${ }^{\dagger} \quad$ W. R. Huntley ${ }^{\ddagger} \quad$ H. Perez-Blanco
}

The emphasis of this program underwent a transiticn during the year in connection with a change in DOE program sponsorship. The original activity, oriented particulariy toward upgrading waste heat from a source temperature of $60^{\circ} \mathrm{C}\left(140^{\circ} \mathrm{F}\right)$, was broadened to an industrial heat pump development program utilizing a wider range of waste heat temperatures and various types of thermally powered heat pumps to deliver recycled industrial process heat to loads at temperatures to $180^{\circ} \mathrm{C}\left(350^{\circ} \mathrm{F}\right)$ or higher. In connection with this transition, ORNL began work on a state-ofthe-art survey and comparative assessment of all identified chemical heat pump concepts, except those repending on chemical reactions [assigned to Idaho National Engineering Laboratory (INEL)], to define the most promising conceptual areas for long-range development. A draft report of this work was completed and included sections prepared by EG\&G-Idaho, Battelle Memorial Institute, and PAR Enterprises. Additionally, testing of the ORNL prototype $\mathrm{LiBr} / \mathrm{H}_{2} \mathrm{O}$ heat pump, designed to upgrade $60^{\circ} \mathrm{C}\left(140^{\circ} \mathrm{F}\right)$ heat, was continued and is discussed further in Sect. 6.2.2.2. Also, a continuation ${ }^{1}$ of analytical model development work resulted in a computer solution to the simultaneous heat and mass transfer for the case of turbulent fluid film flow. ${ }^{2}$ Further details of the beat pump testing and heat/mass transfer experiments are presented in Sect. 6.2.

\subsubsection{Power Systems Technology Program}

T. W. Reddoch?
P. R. Barnes
C. Easterly's
R. J. Lauf ${ }^{\#}$
D. T. Rizy
R. R. Bentz'
R. J. Fox'
J. S. Lawler $\$$
H. Rudrigo"s
R. B. Biggs"*
P. A Gnadt ${ }^{\ddagger}$
R. A. Mathis"
1. Sauers"
J. D. Birduell ${ }^{\dagger \dagger}$
T. L. Hudson"
B. W. McConnell
J. P. Stovall
B. I. Bolfing'
S. R. Hunter ${ }^{\text {H }}$
H. McCoy $\$$
T. K. Stovall ${ }^{\ddagger}$
C. R. Brinkman
D. R. James"
M. O. Pace ${ }^{\dagger}$
R J. Thomas"
E. Broadaway'
W. T. Jewell
S. L. Purucker
P. J. Walsh's
W. L. Bryan'
L. Jungt
D. A. Reed
G. R. Wetherington'
E. E. Calle ${ }^{\text {s }}$
D. M. Kroeger"t
J. A. Reed
R. K. Williams
L. G. Christophorou"
M. A. Kuliasha ${ }^{\ddagger}$

\section{I.A.I Sumary of program scope and coateat}

The Power Systems Technology Program has four major functional categories: power delivery technology, gaseous dielectric insulation, systems engineering, and automation and control. The

\footnotetext{
'Group Leader.

'Consultant, Technion-Israel Institute of Technology, Haifa, Israel.

Engineering Technology Division.

'Program Manager.

Instrumentation and Contro's Livision.

"Engineering Division.

"The University of Tennessee.

"Metals and Ceramics Division.

"Health and Safety Research Division.
} 
program, sponsored by the DOE Division of Electric Energy Systems, is a blend of in-house studies and subcontracts involving private industry (ocnsultants and manufacturcrs), the electric utility industry, and universities. The strategy for solving problems encompasses a combination of computer modeling, laboratory experiments, and field installation experiments. The Energy Division has lead responsibility for the program; however, key roles have been assigned to the Engineering Technology, Engineering, Health and Safety Research, Instrumentation and Controls, and Metals and Ceramics divisions. This report summarizes only the activities for which the Energy Division is directly responsible, but Table 6.1 shows the responsibilities and activities for each division.

Talk 6.1. Responsintities of ORNL research dividions in the Power Syatems Techology Progen

\begin{tabular}{ll}
\hline \multicolumn{1}{c}{ Division } & \multicolumn{1}{c}{ Activities } \\
\hline Energy & High-voltage direct-current (HVDC) system \\
studies, distribution design and protection, \\
load management, power converters, harmonic \\
analysis, electromagnetic pulse effects, \\
and electric field effects
\end{tabular}

\subsubsection{Summary of Exergy Division activities}

A major part of the program is concerned with end-use technologies, including research on distribution automation, customer-side thermal energy storage, and system integration of dispersed generating sources such as photovoltaic or wind machines. Distribution automation uses communication and control between the utility and end-use devices in order to manage equipment capacity more effectively; by using a real-time control system and reducing peak demards and power losses in lines and transformers, energy is distributed more efficiently and reliably through the network. Plans for a large-scale distribution automation and load management experiment to be cunducted on the Athens Utilities Board system at Athens, Tennessee, in cooperation with the Tennessee Valley Authority, have been reported to the utility industry and are discussed further in Sect. 6.2. 
Efforts to determine utilit; interconnection requirements of small, dispersed generating systems have continued. Particular emphasis has been placed on identifying and classifying intertie problems for these systems. The key problems facing small power sources include electric system protection requirements and electric distribution design requirements, including power factor and harmonics. ${ }^{3}$ Work on developing power converters that are microprocessor driven to minimize safety and protection problems" has continued. Variable-speed electric g-nerating systems are being conceptualized to allow for efficient linking of wind electric systems. Control systems have been developed for operating arrays of wind turbines in order to increase the allowable amount of windenergy-generated electricity for electric system intertic.

Studies in high-voltage direct-current (HVDC) transmission systems are in progress. Attention is being devoted to making HVDC a viable alternative to conventional alternating-current transmission. Investigations have been focused on network configuration, control strategies, and circuit breakers, which are critical components necessary for HVDC systems.

A study to assess the effects of electromagnetic pulse (EMP) from a nuclear explosion on the U.S. power system began in response to concern abcut the uational security aspects of such an occurrence. Considerable effort has been devoted to planning the study, and a three-phase approach has been formulated. In Phase I, the expertise in EMP phenomena and power system analysis will be merged to develop a theoretical motel of the power system relative to an EMP event. This effort has been initiated, and attention is iveing focused on the carly time response of the EMP pulse. Models to characterize coupling of the pulse to electric power systems are being developed. In Phase II the model wall be developed, and testing will be conducted to verify it. In Phase III the model will be used in developing recommendations to mitigate the effects of an EMP event on the power system. This work is a major portion of the DOE EMP research program.'

\subsubsection{Building Thermal Envelope Systems and Insulating Materials Program}
T. S. Lundy"
K. W. Childs ${ }^{\dagger}$
G. E. Courville
D. L. McElroy'
J. E. Christian
M. C. Matthews
H. B. Shapira"•

The Building Thermal Envelope Systems and Insulating Materials (BTESIM) Program performs long-range generic research to innestigate mechanisms and perform evaluations of energy transport into and out of the building envelope. The program, sponsored by the DOE Office of Buildings Energy Research and Development, was initiated by a team of DOE, ORNL, Lawrence Berkeley Laboratory (LBL), and National Bureau of Standards (NBS) staff members, primarily under DOE sponsorship, who developed a joint program plan ${ }^{6}$ that was made national in scope by a

\footnotetext{
'Program Manager, also Task Leader for Adninistration/Technical Support/Selected Technical Projects on loan to the Energy Division from the Metals and Ceramics Division.

'Computer Sciences Division.

"Group Leader, also Task Leader for Systems and Diagnoutica, Tnergy Division.

Administrative Assistart, on loan to the Energy Division from the Metals and Ceramica Division.

'Group Leader, also Task Leader for Materials, Metals and Ceramics Division.

"Task Leader for Research Utilization, Energy Division.
} 
review process that included comments and contributions by both the private and public sectors of the building community. The objectives of this program are (1) to produce the technical data, test procedures, guidelines, and consensus standards needed by manufacturers, designers, and builders to produce buildings of bigh energy efficiency while concurrently meeting safety, durability, habitability, and economic requirements and (2) to emphasize the need for imfioved processes for the implementation of new technology in the design, construction, and operation of buildings to achieve technically and economically feasible energy conservation.

ORNL has been responsible for implementation of the DCE part of the BTESIM National Program since its inception about five years ago. This work has included overall planning and guidance performed jointly with the total building community, with rccent emphasis on creation and operation of the Building Thermal Envelope Coordinating Council (BTECC). This new institutional arrangement has formalized the coordination of multiple public and private research efforts, with "Research Coordinating Committees" operatirg in various technical areas such as roofing, moisture, and whole-building performance.

The BTESIM Program operates primarily with DOE funding under five tasies, as follows: a management task; a task on research utilization; and three research tasks-materials, envelope systems, and diagnostics. The materials task is conducted by the Metals and Ceramics Division.

The research utilization task includes several ongoing educational thrusts such as seminars for faculty members of schools of architecture and engineering and student design competitions. It also has shorter range technology transfer effnrts reflecting the BTESIM philosophy that the research output must be put into the right places in the correct language to vause energy-conserving decisions.

The envelope systems task deals with static and dynamic aspects of energy flow into and out of ceiling/attic/roof, wall, and floor/earth contact systems that comprise the building envelope. During this year, considerable effort was expended on dynamic thermal performance of test cells in New Mexico and in Maryland (near Washington, D.C.) to determine thermal mass influences. Initiation of research at ORNL on energy-efricient roofing systems was also accomplished through design and construction of a Roof Testing Facility (RTF) at the X-10 site. Technical highlights on thermal mass, roofing research, and thermal analysis of the Joint Institute Dormitory are presented in Sect 6.2 .4 .

\subsubsection{Rexidential Conservation Service Program}
W. R. Mixon
F. D. Boercker
M. A. Karnitz
H. A. McLain
M. A. Broders ${ }^{\dagger}$
R. J. Kedl
S. Y. Ohr
L. Jung ${ }^{\ddagger}$
L. N. McCold
T. K. Stovallt

The Residential Conservation Service (RCS) and Commercial and Apartment Conservation Service (CACS) programs are administered by the DOE Office of Buildings Energy Research and

\footnotetext{
'Program Manager.

Group Leader.

'Engineering Technology Division.

Computer Sciences Division.
} 
Development, for which ORNL has been designated lead laboratory. These services were established by law to facilitate retrofitting energy conservation and renewable resource measures in single-family, multifamily, and small commercial buildings. DOE is responsible for establishing rules for states to implement these services, which require utilities and major fuel suppliers to offer building energy audits with estimates of energy savings for specified retrofits. The purpose of the ORNL RCS program is to provide

1. technical support to DOE for RCS and CACS rule-making activities;

2. tcchnical assistance to DOE, states, and utilities for implementation of rules;

3. research to provide a sound technical basis for the programs; and

4. evaluation of the actual effectiveness of selected state programs (see Sect. 5.2.1).

The RCS program is a multidisciplinary activity supported by fon ORNL' divisions and cooperative efforts with the Solar Energy Research Institute (SERI), Argonne National Laboratory (ANL), and LBL. The Engineering Technology, Information, and Health and Safety Research divisions of ORNL are active participants in the program.

Rule-making activities during this period led to publication by DOE of the RCS Federal Standby Plan (September 1983) and final submission of the CACS Program rule (published in October 1983). The procedure for each inciuded publication of a proposed rule for public comment followed by issuance of a final rule. ORNL summarized and developed searchable data bases of public comments and analyzed technical issues for preparation of both final rules and prepared a management plar for DOE to implement the RCS Federal Stardby. Additional technical support for RCS included review of modifications to state plans, revision of the RCS Model Audit Manual for single-family houses, and development of a model audit for individually heated and cooled apartments.

Technical assistance for CACS included preparation of a regulatory impact analysis and an environmental impact statement to support the final rule and completion of a draft implementation guide. Also completed were a report describing prototypical buildings covered by CACS and walkthrough audit procedures for 7 of the $\mathbf{2 0}$ conservation measures and for five of the nine operation and maintenance procedures for commercial buildings.

RCS research efforts during this period were focused on verification and improvement of computational procedures in the Model Audit. Additional conservation measures were assessed, and procedures for heat pump desuperher.ters for heating water and add-on heat pumps were added to the Model Audit. Add-on heat pumps are discusseat further in Sect. 6.2.5.

\subsubsection{Work for Other Government Agencies}
F. D. Boercker
W. L. Jackson
L. N. McCold
M. A. Brooers
M. A. Karnitz
H. A. McLain
F. C. Chen
J. O. Kolb
R. W. Murphy ${ }^{\dagger}$
G. E. Courville

Expertise developed in district heating and cogeneration, energy conservation retrofit options, and heat pump modeling was applied to a variety of non-DOE programs. A feasibility study on the

\footnotetext{
"Computer Sciences Division.

'Engineering Technology Division.
} 
use of small, packaged cogeneration systems for individual buildings was completed for the U.S. Navy. A pressure-flow model der joped to analyze steam distribution systems was used to assess energy losses and possible savings for a U.S. Army district heating system at Fort McClellan and for the steam system at ORNL. An option to replace portions of the ORNL steam system with a hot water system was assessed and recommended as a better investment than a major steam system renovation being considered (see Sect. 6.2.6.2).

The Navy Shipboard Heat Pumps project for the David W. Taylor Naval Ships R\&D Center (U.S. Navy) has been active for thrce years. During the past year, the major emphasis of the project has been or: the continued development of a computer-aided design (CAD) program for shiptoard heat pumps and the feasibility study of heat pump performance enhancement options using the CAD program. Additionally, research was initiated to investigate alternate heat recovery concepts other than boilers for the utilization of shipboard waste heat resources.

Projects initiated for the U.S. Army Facilities Engineering Support Agency included (1) validation of energy and cost savings for selected retrofit projects under the Energy Conservation Investment Program and (2) a study of the needs, scope, and operation of an Energy Conservation Technical Information and / nalysis Center to be operated by that agency.

Also, a project was initiated for the U.S. Air Force to evaluate the cost-effectiveness of alternative insulated roofing systems for low-slope roofs to help establish roofing standards for application on Ai. Force bases.

\subsection{TECHNICAL HIGHLIGHTS}

\subsubsection{Building Equipment Program}

\subsubsection{Adranced absorption cycle derelopment}

\section{G. T. Privon, R. C. DeVault}

The Advanced Absorption Cycle Development program was conceived in late CY 1981 with a goal of developing, through proof of concept, high-efliciency absorption cycle heat pumps. Firstgeneration single-stage absorption systems have been developed' to give a coefficient of performance (COP) of 1.25 for heating at $8.3^{\circ} \mathrm{C}$, including combustion efficiency; the minimum performance tirget for the advanced cycles is 1.6 COP (heating) for the same conditions. In April 1982, a request for proposal was distributed to more than 50 potential bidders, and 12 bids were received. Three contractors were selected for the Phase I analytical evaluation work under the program, and work was started in early FY 1983. The three contractors are Carrier Corporation, Trane Company, and Phillips Engineering Company.

The esults of the analytical evaluation were encouraging; several different methods for achieving higher efficiency were identified. These include (1) several cycles using existing commonly used absorption fluids; (2) the use of other absorption fluid mixtures containing commonly available chemicals, but in new crmbinations; and (3) the use of capacity modulation to increase seasonal performance for any leve! of hardware development.

The "near-term" advanced cycle hardware using common absorption fluids has calculated heating COPs in the 1.6 to 1.8 range, with cooling COPs (at $35^{\circ} \mathrm{C}$ ) of 0.7 to I.0. The use of other absorption nuid mixtures selected for use in the advanced cycles has opened the possibility of heating COPs above 2.0 and cooling COPs of 1.4 to 1.8, which, if achievable in practice, would represent a breakthrough in perforn nce of absorption equipment. Finally, capacity modulation 
may result in a seasonal performance that would approach the steady-state values by reducing cycling losses.

Work on the development of proof-of-concept hardware with which to realize these high efficiencies is currently proceeding.

\subsubsection{Capacity nodulatios of air-to-air heat pamps}

R. D. Ellison, C. K. Rice

Capacity modulation is often consideres, as a way to reduce losses that occur when heat pumps are cycled on and off during part-load operation.' However, there are additional efficiency benefits, other than the cycling-loss reduction, which, taken together, are of even greater magnitude. Analytical tools previously developed at ORNL were used to quantify these additional benefits and to find heat pump configurations that maximize the potential energy savings due to the application of capacity modudation concepts to residential heat pumps.

In order to provide a basis for meaningful comparison, systems to be compared were optimized for best annual performance (i.e., both heating and cooling performance) subject to engineering constraints, which are also implicit cost constraints. The ORNL Heat Pump Model ${ }^{7}$ was used to calculate the steady-state performance of systems being optimized, and an annual performance model was used to provide seasonal and annual performance factors for a given house and locatior. Both of these programs were placed under the control of numerical optimization routines ${ }^{8}$ to automate the process of finding design embodiments sf madulating and nonmodulating heat pumps which provide optimal annual performance. Among the constraints was a requirement that component efficiencies and sizes be limited to those now available, except for devices that change or control motor speeds. It was assumed that motor speed controllers would become less costly and more efficient over the range uf expected motor loads as the new technology develops.

Calculations were made for nunmodulating heat pumps with typical frosting and cycling losses and with reduced losses. Frr modulating sysiems, typical and (estimated) reduced losses were considsred for advanced, rintinuously variable-speed control methods. Energy use and savings for a continuously modulating heat pump are compared to those for a nonmodulating one in Fig. 6.1, which is based on calculations for a $167-\mathrm{m}^{2}$ house in Nastiville, Tennessec. In this city, the continuously modulating heat pump would show an annual performance factor (APF) of 3.22, a $30 \%$ increase over that for an optimized single-speed system (2.46). Additional advances are still possible by further reducing cysling losses and by eliminating the losses inherent in the speed control.9 A breakdown of energy use for the modulating heat pump is shown by the larger sector shown in the diagram; energy use of a non-modulating heat pump in the same application is given by the sum of the two sectors. It is impertant to note that the reduction in cycling losses achiever by modulation is only about one-third of the total savings due to modulation. For a more nort erly climate, this fraction could be even smaller.

\subsubsection{Ground-coupled heat pamp research}

P. D. Fairchild, V. D. Baxter, V. C. Mei

Another means of improving the performance of heat pump cycle equipment is to use a heat source and sink with less extreme temperature swings than outdoor air, such is well water or the 
OnNe OWG as izo

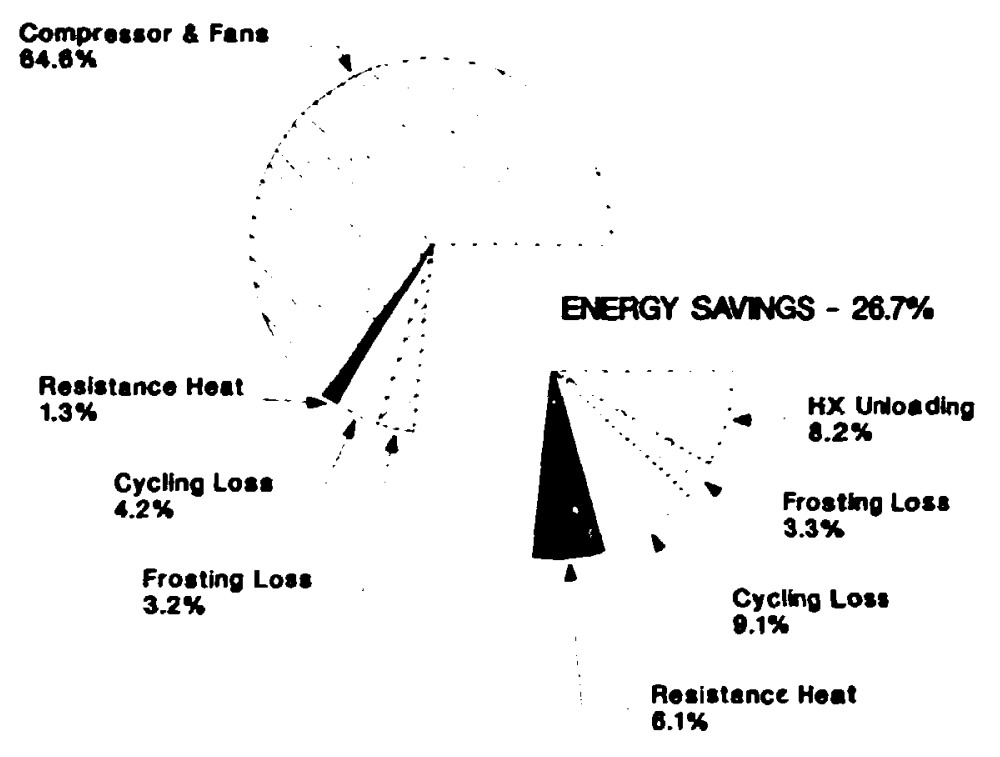

Fig. 6.1. Eneriay ese and savings for a continoosisy modulating heat promp.

earth. Heat pumps in which earth is used as the heat source (during heating) and sink (during cooling) are normally of the water-to-air or water-to-water type, in which an antifreeze solution is pumped through an intermediate heat transfer circuit that couples the heat pump and a pipe coil embedded in the earth (which functions as the earth heat exchanger).

Common design configurations of the ground coil heat exchanger include concentric tube and U-tube (i.e., two pipes connected by a $180^{\circ}$ bend or fitting) closed-loop arrangements installed in vertical wells and horizontal serpentine coils installed in shallow trenches. Experimental testing and analytical evaluations aie under way to establish the technical limitations and preferred design configurations for various soil and weather conditions.

In operation, a heat pump ground coil will impose a temperature differential between the coil and the ground and a temperature gradient in the ground which will cause moisture migration (toward the lower temperature). In the heating mode the coil can become culd enough to cause freezing of the soil moisture around the coil. The performance of ground coils during cooling mode operation is not well understond because the rejection of heat to the earth causes migration of moisture away from the coils. This moisture migration results in drying out of the soil and thus reduced heat transfer.

Despite renewed inierest being shown in this technology by electric utilities and others, there is not an adequate ground coil analytical method that accounts for these effects. Work is therefore in progress to derive such a comprehensive analytical design method that is based on the theories of heat and mass transfer, coupled with phase change, in porous media. Model development and validation work is proceeding progressively, starting with a heat-transfer-only model for single coils, and eventually will include soil freezing, moisture migration, surface effects, and thermal interaction of adjacent coils. The heat-transfer-only model is completed and has been validated against laboratory data. ${ }^{10}$

The model that considers beat transfe: coupled with phase change was also completed and is now being validated. In this connection, a cooperative working arrangement has been implemented 
with Niagara-Mohawk, a New York-based utility company, to provide them techrical assistance with instrumentation on their ground-coupled heat finp (GCHP) project in return for experimental data ve can use for validation of these models.

Experimental projects are also being conducted on two horizontal-coil and one vertical-coil experimental GCHP installations. Results are summarized in Tabie 6.2 .

Talk 6.2 Experineatal resilta en GCHP projects

\begin{tabular}{|c|c|c|}
\hline \multirow{2}{*}{ Project } & \multicolumn{2}{|c|}{ Seasonal performance factor } \\
\hline & Heating (SPFH) & Conling (SPFC) \\
\hline $\begin{array}{l}\text { TECH site" } \\
\text { horizontal coil, } 213 \mathrm{~m}\end{array}$ & $2.6^{6}$ & 1.3 \\
\hline $\begin{array}{l}\text { BNL sitef } \\
\text { horizontal coil }\end{array}$ & 25 & 1.9 \\
\hline $\begin{array}{l}\text { TECH site } \\
\text { vertiral coil, } 140 \mathrm{~m}\end{array}$ & $f$ & 2.0 \\
\hline
\end{tabular}

\footnotetext{
Tennessec Energy Consenation in Housing (TECH) site near Knoxville, Tenneasee.

See ref. 11.

Broothaven National Laboratory (BNL) site on Long Island, New York.

'See ref. 12.

'Actually, there are six coils (noles) ranging from 19, to $30 \mathrm{~m}$ deep.

No data available; teating was started in the summer of 1983.
}

Heating mode tests of the horizontal-coil installation at the TECH site showed a seasonal heating performance about $30 \%$ better than an air-source heat pump system with equivalent technology (seasonal performance factor for heating of 2.6 vs 2.0). However, the experimentally observed seasurial cooling performance with these horizontal-coil systems showed a performance degradation, particularly at the TECH site. In a similar test at BNL, the sandy soil there apparently provides good earth-to-coil contact for heat transfer without any special precautions in backfilling, whereas we found evidence that the clay soil at the TECH site did not, even after extended ground settiing. In contrast to the horizontal-coil results, the vertical-coil experiment at the TECH site showed a seasonal performance factor for cooling of 2.0. This improved performance is largely due to better coil-earth heat transfer since the vertical coil extends below the water table into saturated soil.

\subsubsection{Stirline-cycle beat panp}

\section{F. C. Chen, N. Domingo}

This project is concerned with the technical support and feasibility assessment for the development and demonstration of an electric or engine-driven Stirling-cycle heat pump (SCHP) as

\footnotetext{
"On Ioan from Engineering Technology Division.
} 
a viable and conomically competitive heat pump option for residential applications. This activity involves a sequence of subcontracted projects that are integrated with ORNL work. Durieg the past year, work was focused on two principal areas: (1) 3 computer simulation of a kinematic SCHP using a modified version of the NASA-Lewis ixssearch Center third-order code, which employs rndal analysis to solve the guverning differertial equations numerically; and (2) inder subcontract to Martini Engineering, the development of a user-oriented computer code with a storter computing time capable of simblating SCHPs of different mechanical arrangements.

Parametric and s=nsitivity analyses carried out with the NASA code determined the effects of working fluid, outdoor air (source) temperature, mean gas pressure, crank speed, and heat exchanger design paramefers on SCHP performance. Figure 6.2 shows the indicated ineating COP as a function of ambient air temperature for a fixed crank speed and mean gas pressure. The values for COP include flow friction losses tut exclude mechanical losses; COP is defined here as the heat

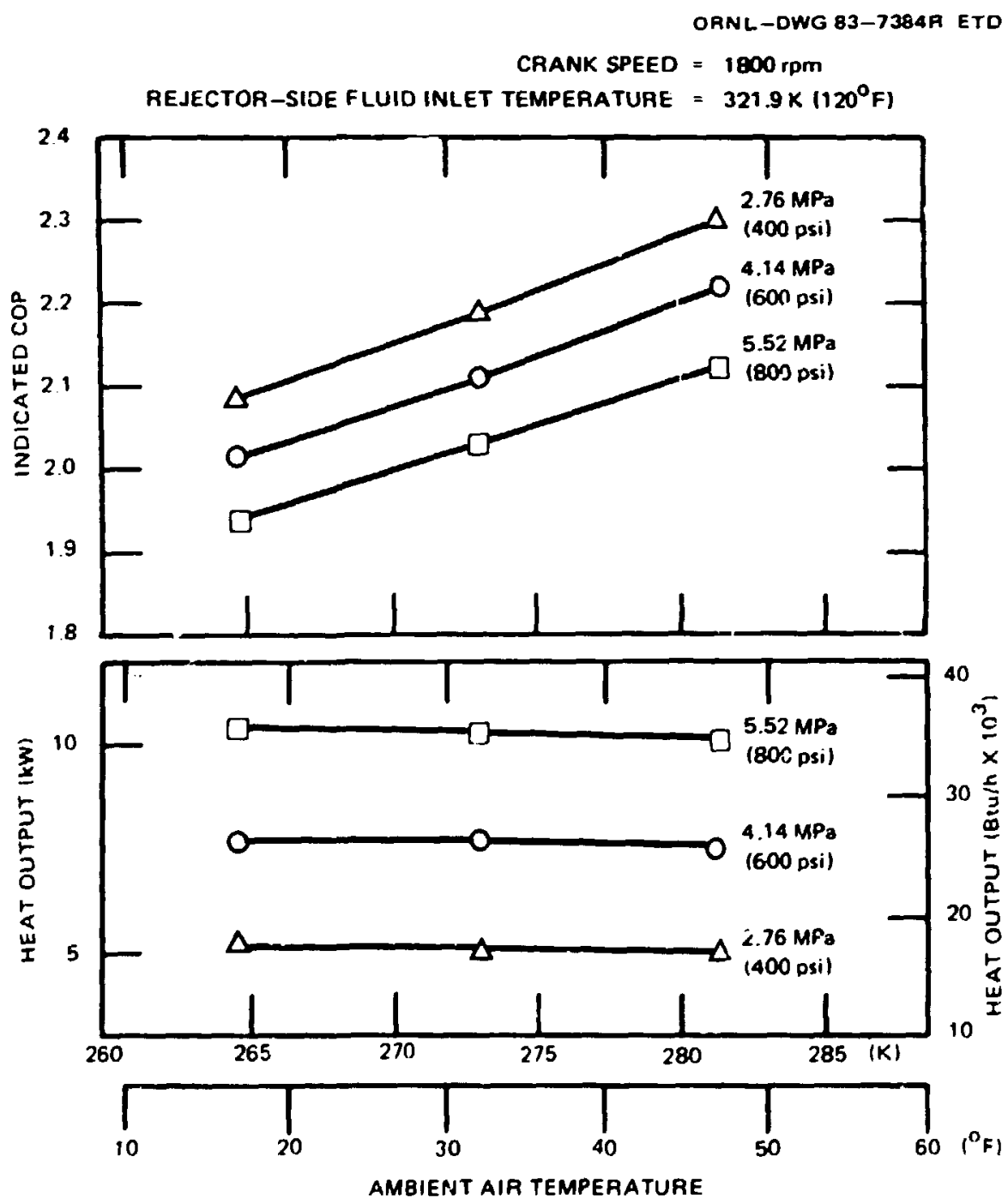

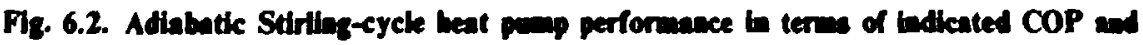

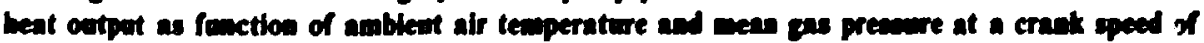
$1800 \mathrm{rpm}$. 
out divided by the equivalent sinaft work at the fower piston. The values are based on nearly adiabatic expansion and compression conditions. As illustrated in Fig. 6.2, COP values tended to decrease with decreasing outdoor air temperature but much more slowly than with conventional vapor compression beat pumps. Also, in contrast to the sharp drop of heat output of vapor compression systems with ambient temperature, the heat output capacity of the SCHP is unaffected by changes 1 outdoor air temperature. This is due primarily to the fact that the density of the working fluid, usually high-pressure bydrogen gas, is insensitive to outdoor air temperature, whereas in the vapor compression cycle the working fluid density at the compressor suction is greatly influenced by this temperature and therefore directly affects the compressor mass flow rate and thus the overall cycle performance. These results suggest the possible application of the SCHP in colder climates.

Because the NASA code simulates the expansion and compression processes of the SCHP to be adiabatic rather than isothermal, as in the case of the ideal Stirling cycle, a substantial loss in heat pump performance results. The effict of isothermslization on COP is being investigated by expanding the utility of the NASA $c 0^{-1}$. Preliminary results indicate that a projected increase in COP of 41-61\% above adiabatic conditions, depending on outdoor air temperature, might be possible. A subcontracted laboratory experiment that is devised to impreve the performance of the SCHP through isothermalization of cycle heat transfer processes is being pursued.

\subsubsection{Industrial/Chemical Heat Pumps}

\subsubsection{Combined heat and meses trassfer}

\section{H. Perez-Blanco}

Effort in this area was focused on evaporatively cooled heat exchangers and on hasic studies of heat and mass transfer in falling films. Evaporatively cooled heat exchangers are an alternative to air- or water-cooled heat exchangers for heat sejection to the environment. A mixture of water and atmospheric air is used as the cooling medium. Previous work on an experimental, vertical tube heat exchanger has shown that, in many applications, the controlling resistance to heat transfer takes place at the air-water interface. To decrease this controlling resistance, heat transfer enhancement techniques must be used. During this fiscal year the design and testing of coiled wire turbulence promoters for heat transfer enhancement were undertaken. Two turbulence promorers similar to the one shown in Fig. 6.3 were tested in a vertical tube, but with different spacings from the wall. It was found that the heat and mass traisfer coefficierits may be enhanced by values ranging from $30 \%$ to $75 \%$ of the smooth tube value. The preferred design for minimizing the air pressure drop was identified. The effectiveness of turbulence promoters for heat and mass transfer enhancement, as an alternate way to extend surfaces, was shown. The results of this testing are now being documented.

Also, a report ${ }^{2}$ describing a theoretical analysis of the combined heat and mass transfer process taking place in the absorption of a gas or vapor into a turbulent liquid filan was published. Eddy diffusivity correlations were used to describe the transport near the wall and the interface and in the bulk of the film. The energy and diffusion equations were solved simultanesusly to give the temperature and concentration variations in the film (Fig. 6.4). Two cases of interest were considered: a constant-temperature case and an adiabatic wall. The Nusselt and Sherwood numbers 
III

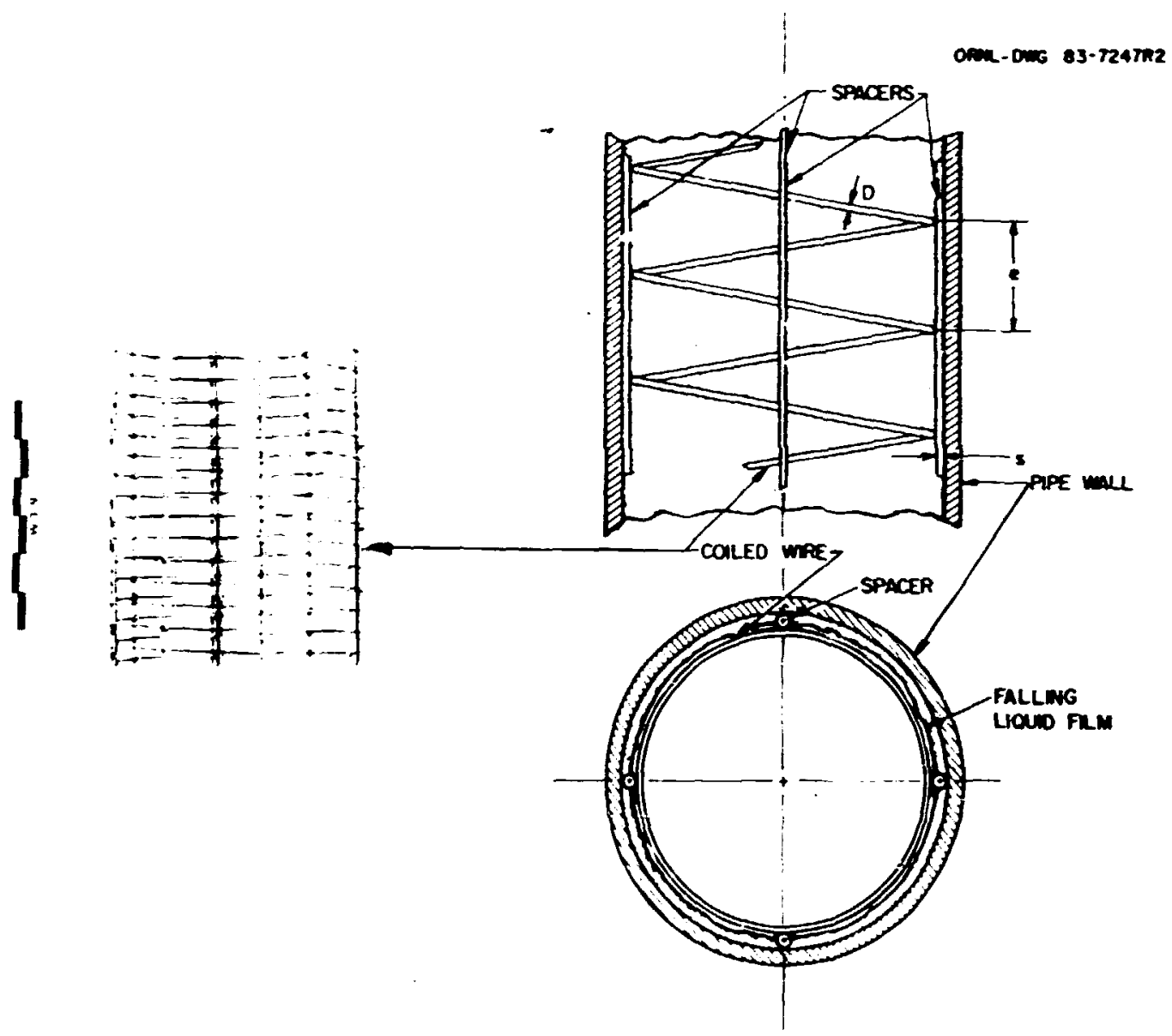

Fig. 6.3. Schematic of an installed spiral wire turburleace promoter. $D=0.5 \mathrm{~mm}$; $=5 \mathrm{~mm}$; and s = 0.25 and $0.50 \mathrm{~mm}$.

were expressed in terms of the operating parameters, from which heat and mass transfer coefficients were determined. This work can be applied in the design of absorption machines.

\subsubsection{ORNL absorption heat peupp}

W. R. Huntley

An absorption heat pump incorporating an adiajatic absorption feature' for upgrading industrial waste heat to proiess steam temperatures was developed and successfully tested ai ORNL during this fiscal year. The heat pump is designed to operate with waste heat temperatures ranging from $60^{\circ} \mathrm{C}$ to $100^{\circ} \mathrm{C}$. In this type of heat pump, most of the energy for operation comes from the waste heat, with minor inputs of electrical energy for fluid circulation. Electrical COPs ranging from 50 to 70 have been demonstrated. The successful operation of inis lithium bromide/water absorption heat pump has demonstrated that this concept is a practical candidate for energy recovery from waste heat in industrial applications where low-temperature process steam is needed. 


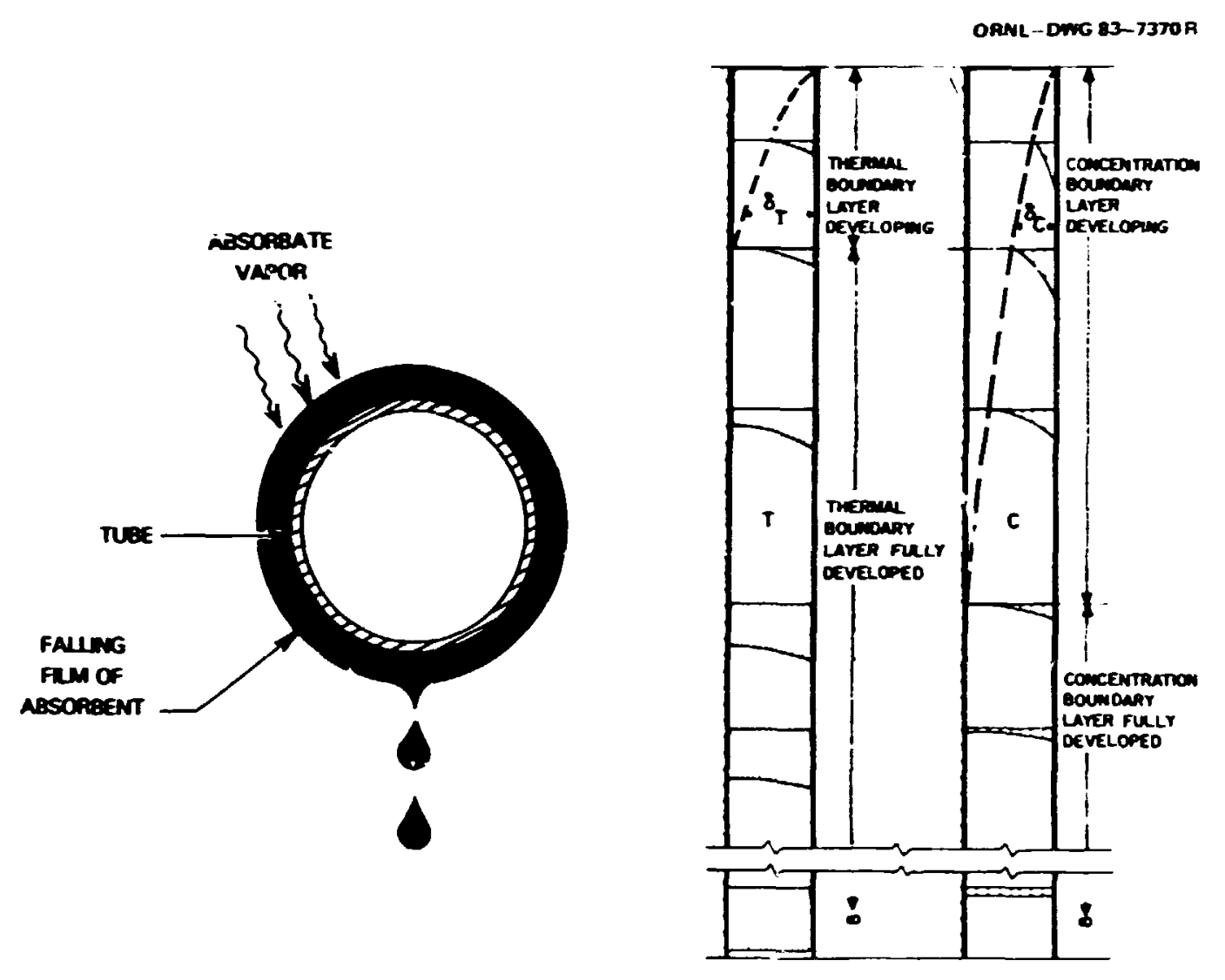

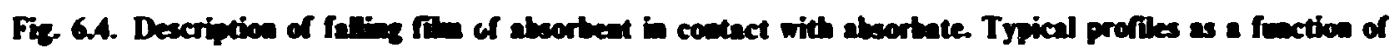
bistance are show for temperature, T, and concentration, C, abone with the thernal and concentration lowatary

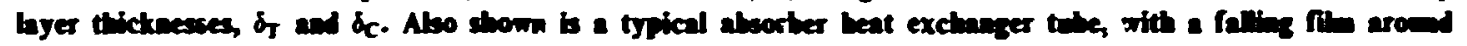
the tube perimeter.

Overall periormance data for the single-stage absorption heat pump (Fig. 6.5) show excellent agreement with theoretical prediction $i_{.}^{13}$ However, theoretical analysis of the actual performance of the adiabatic absorption section has shown that the liquid-vapor contact provided during droplet formation and growth was already ample, with $\mathrm{LiBr} / \mathrm{H}_{2} \mathrm{O}$, to provide fully adiabatic absorption in the existing geometry. When waste heat temperatures are at the lower end of the range evaluated in this program, the output of single-stage heat pumps would be hot water, which would be of limited value in many applications. A preliminary design of a two-stage system has been coinpleted, and its performance predictions show that process steam can be produced from a $60^{\circ} \mathrm{C}$ waste heat source.

An economic analysis of two-stage heat pumps was made based on the actua! performance data of this single-stage prototype heat pump. The simple payback times are shown in Table 6.3 for three different condenser water inlet temperatures and three different wasie heat temperatures. Payback times vary from 1.4 to 5 years, depending on the size of the heal pump, waste heat temperature, and condenser waier inlet temperature, and would thus appear to make the heat pump an attractive industrial irvestment wherever an appropriate waste heat source is available along with a need for relatively low-temperature process steam. 


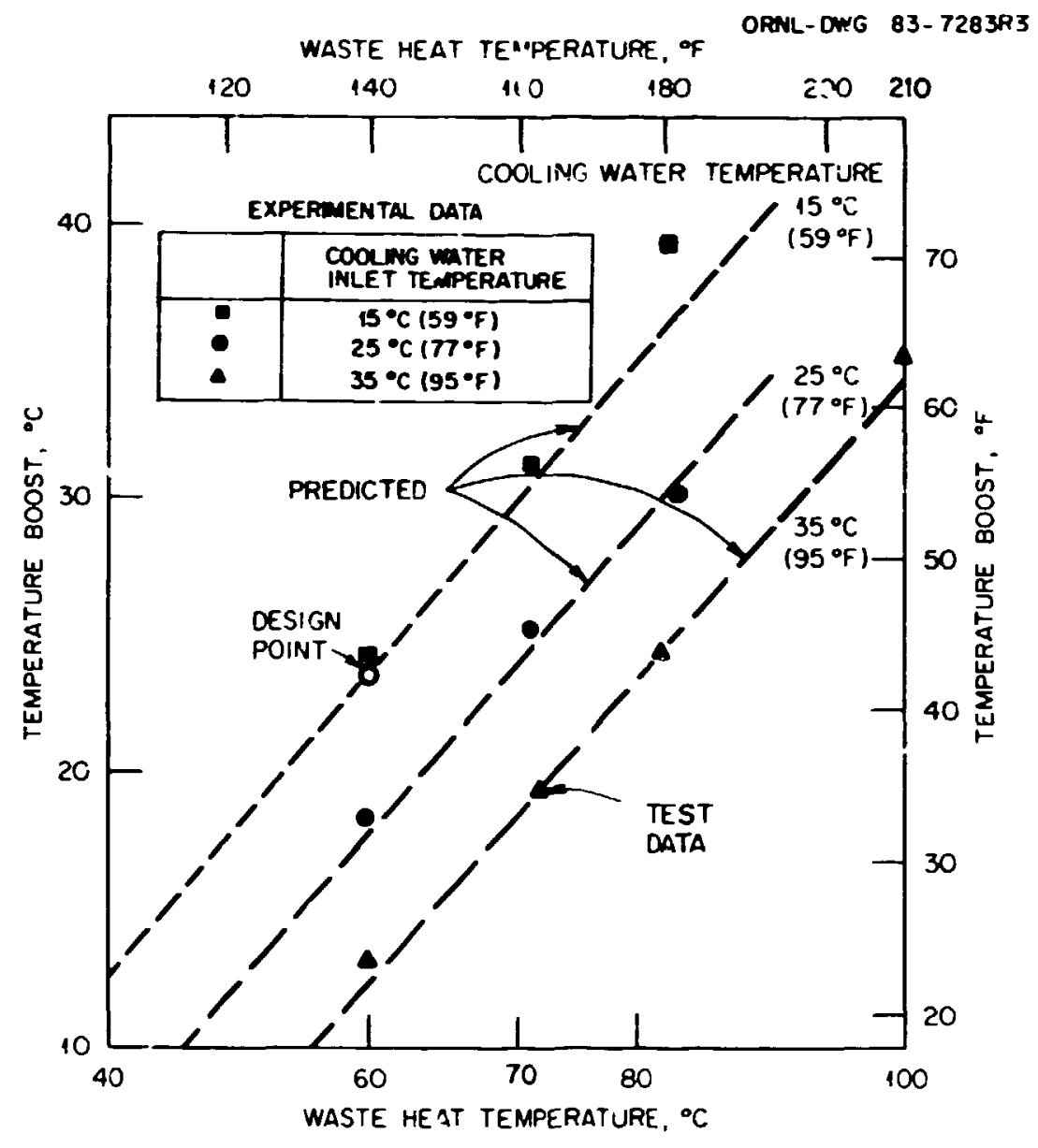

Fig. 6.5. Teat data from single-stage $\mathrm{LiBr} / \mathrm{H}_{2} \mathrm{O}$ absorption heat pomp.

Table 6.3. Simple payback times for two-stage heat pamp operating continoously"

\begin{tabular}{|c|c|c|c|c|c|c|c|c|c|c|}
\hline \multirow{4}{*}{$\begin{array}{l}\text { Output capacity } \\
\text { with waste heat } \\
\text { at } 60^{\circ} \mathrm{C} \text { and } \\
\text { condenser inlet } \\
\text { water at } 15^{\circ} \mathrm{C} \\
\left.[\mathrm{kW} \text { (tons) })^{b}\right]\end{array}$} & \multirow{4}{*}{$\begin{array}{c}\operatorname{Cost}^{c} \\
\left(S \times 10^{3}\right)\end{array}$} & \multicolumn{9}{|c|}{ Payback time (years) } \\
\hline & & \multicolumn{3}{|c|}{$15^{\circ} \mathrm{C}$ condenser } & \multicolumn{3}{|c|}{$25^{\circ} \mathrm{C}$ condenser } & \multicolumn{3}{|c|}{$35^{\circ} \mathrm{C}$ condenser } \\
\hline & & \multicolumn{3}{|c|}{$\begin{array}{c}\text { Waste heat } \\
\text { temper_ture }\left({ }^{\circ} \mathrm{C}\right)\end{array}$} & \multicolumn{3}{|c|}{$\begin{array}{c}\text { Waste heat } \\
\text { temperature }\left({ }^{\circ} \mathrm{C}\right)\end{array}$} & \multicolumn{3}{|c|}{$\begin{array}{c}\text { Wasie heat } \\
\text { temperature }\left({ }^{\circ} \mathrm{C}\right)\end{array}$} \\
\hline & & 60 & 71 & 82 & 60 & 71 & 82 & 60 & 71 & 82 \\
\hline $\begin{array}{c}880 \\
(250)\end{array}$ & 411 & 2.6 & 2.0 & 1.7 & $3.3^{d}$ & 2.4 & 2.0 & $5^{d}$ & 3.3 & 2.5 \\
\hline $\begin{array}{c}3520 \\
(1000)\end{array}$ & 1404 & 2.2 & 1.7 & 1.4 & $2.8^{d}$ & 2.0 & 1.7 & $4.2^{d}$ & 2.8 & 2.1 \\
\hline
\end{tabular}

'Steam value $=\$ 6 / 10^{\circ} \mathrm{J}\left(\$ 6 / 10^{6} \mathrm{Btu}\right)$.

Ton capacity $12,000 \mathrm{Btu} / \mathrm{h}$.

'Based on 1983 costs for chillers plus 25\% for site preparation costs as given in R. S. Means, Mechanical and Electrical Cost Data, Sixth Annual Edition, R. S. Means Publishing Co., Kingston, Mass., 1983.

These specific operating conditions will be of limited application becarse the output of the heat pump is hot water, not steam. 


\subsubsection{Power Systems Technology Program}

\subsubsection{Athens Antomation and Control Experiment}

\section{S. L. Purucker, T. W. Reddoch, J. A. Reed, D. T. Rizy}

The Athens Automation and Control Experiment (AACE), sponsored by the Electric Energy Systems Division of DOE, is being conducted in cooperation with the Tennessee Valley Authority (TVA) and its associated power distributors, represented by the Tennessee Valley Public Power Association. The Electric Power Research Institute (EPRI) has recently joined the effort. The primary goal of the project is to show by experiment the feasibility and practicality of a fully automated distribution system. The key distinguishing aspect of this project is the integration of the automation and control functions into a single system.

The AACE is a major test of automation techniques for electric distribution systems and should quantify the associateo benefits and costs and relate these capabilities and benefits to bulk power system operations. A key element in the experiment is the design of the hardware/software associated with the computer, communications, and control systems which constitute the automation system. This configuration is referred to as the intigrated Distribution Control System (IDCS) since it combines the attributes of supervisory control and data acquisition (SCADA), distribution automation, and load control. The IDCS integrates these entities into a unified system for the purpose of managing electric distribution operations and linking distribution control actions to the bulk operations. During this year, the specifics of the design of the IDCS were completed, and hardware implementation is in process.

The design of the IDCS blends well into the typical bulk power communication and control hierarchy consisting of generation and transmission SCADA control. The top level of the hierarchy consists of the power system control center, which coordinates the dispatchable thermal generation for the TVA system. The power system control center, in turn, coordinates with five area transmission SCADA control centers at the second level.

The third level in the hierarchy consists of the communications and control center located at the Athens Utility Board's main office. The computer configuration is a dual DEC $11 / 44$ fully redundant computer system with 1 megabyte of main memory each. Two DEC RA60 disks will be available to each machine, providing 414 megabytes per machine. This storage capacity is augmented by magnetic tape drives.

The fourth level in the control hierarchy exists at the distribution substation and consists of substation sensors and control relays which automate the substation in a typical SCADA fashion. Additionally, feeder communication is provided by substation signal injection equipment, which injects a $340-\mathrm{Hz}$ (ripple) voltage signal into the $60-\mathrm{Hz}$ power system to communicate to the various devices on the feeder. The distribution devices of the fifth hierarchy level are controlled by either the power line ripple signal or by direct phone line.

A more detailed view of the communication and control system, which is being provided by Brown Boveri Control System, Inc. (BBCSI), is shown in Fig. 6.6. The solid lines indicate the communication medium. Figure 6.6 shows a dedicated leased telephone line that exists between the communication control center (CCC) and the substation and feeder remote transponder units (RTUs). Control signals are initiated at the CCC and sent to the substation for execution. Data sensed at the substation through potential transformers and current transformers are sent back to the CCC. Information such as breaker status, tap setting on the transformers, voltage values for 


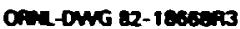

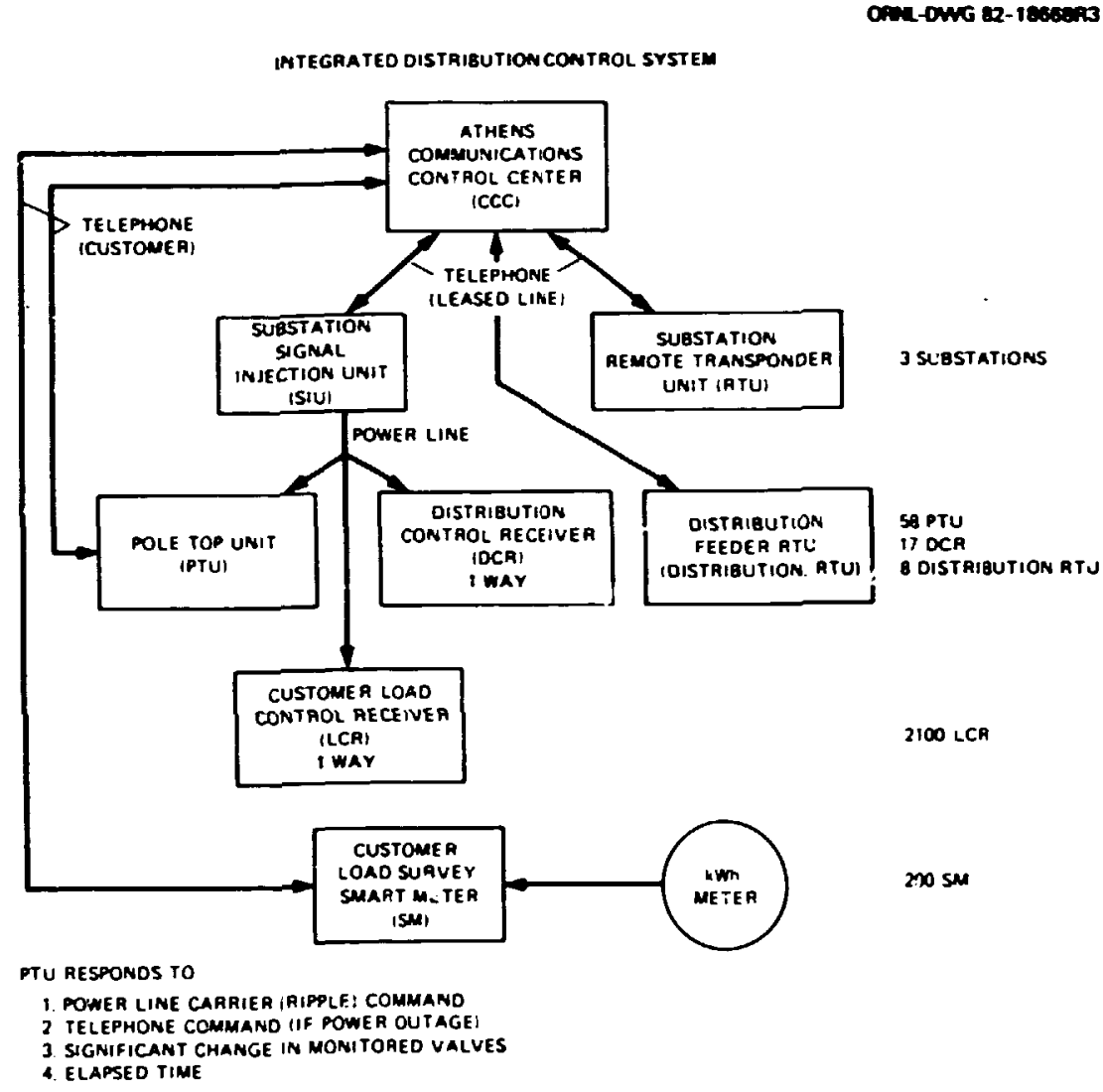

Fig. 6.6. Comanaication and control system.

each phase, and real power and reactive power loadings for each feeder is then stored in the central dat: base.

When communication is required to the distribution feeder (Fig. 6.6), a signal is initiated at the CCC and sent down to the substation signal unit, which injects a $340-\mathrm{Hz}$ ripple signal onto the normal $60-\mathrm{Hz}$ voltage waveform. This signal is then propagated down the distribution line, and each uniquely addressed pole top unit (PTU) responds to the control signal if called upon to switch. Data sensed at the local PTU location are sent back to the CCC data base via a 300-baud telephone partyline. This telephone line offers the advantage of operating cost reduction when compared to dedicated leased lines for RTU installations.

Because the ripple signal propagates through distribution pole transformers, the customer load control signal is transmitted into the house. Three relays are available in the customer load control receiver. One 30-A relay is used for switching hot water heaters, etc., and two 6-A relays are used for switching 24-V control circuits associated with central heat, air conditioning, and other designated loads. Alternate relay configurations can be used for industrial and commercial customers that participate in the project.

Customer load survey information is obtained from a smart meter using the existing customer kiiowatt-hour meter. The optical pulse counter electronics unit is added to a standard kilowatt-hour meter. The customer's meter is interfaced with the customer's telephone through additional electronics in the meter. At predetermined intervals, the customer's meter will call the CCC and 
transmit the number of accumulated pulses since the last aall. The number of pulses transmitted corresponds to the number of times the meter has rotated. The customer energy usage patterns are thus quantified. These data are used to verify the impact of various control strategies and provide real time system feedback for operation.

In summary, an IDCS is a system that is capable of switching substation and feeder devices, switching customer loads, and using distributed intelligence; has the ability to monitor status and power system values; will aid the operator in normal and emergency operations; provides coordination etween the bulk povrer system and the distributor, and accommodates dispersed generation. T.: IDCS will be used to develop and implement control strategies to optimize the performance of the generation, transmission, and distribution system.

\subsubsection{Operational and dexigen consibentions for electric distribation systems with dispersed storage and geweration}

\section{T. Rizy, W. T. Jewell, T. W. Reddoch, J. P. Stovall}

Three studies have researched the operational and planning problems associated with connecting small power sources to an electric distribution system. In one study, ${ }^{14}$ the harmonic distortion produced by a subdivision of photovoltaic (PV) arrays connected through linecommutated inverters was simulated. A second study ${ }^{4.15,16}$ examined the protection and safety problems associated with the operation of small ac generators and dc-to-ac inverters. A third study assessed the effects of dispersed sources and distribution planning and design. The purpose of the studies was to determine the adequacy of the electric utility industry's traditional practices, hardware, and design for the operation of dispersed storage and generation (DSG) devices. As a result of these studies, recommendations for accommodating this new technology and areas needing further research were identified.

Immediate concerns for electric utilities. In the short term, electric utilities will experience low penetrations of DSG devices connected to the existing distribution system. Study results indicate that only minor changes in safety practices and protection hardware may be required for low penetrations of DSG devices. Additional feeder switches and lockout disconnect switches at the DSG installations would reduce the size of feeder stations with DSG and prevent the reenergization of a deenergized feeder station during maintenance on the system or at a DSG installation. Because of DSG infeed to faults, fuse sizes may need to be increased and raloser settings delayed to prevent damage to DSG devices operating out of phase with the utility system following the occurrence of a system disturbance. The placement of capacitors to correct the power factor of DSG devices must take into consideration the possibility of DSG islanding and resonant overvoltage situations.

Power quality problems associated with dc-to-ac conversion for DSG installations can be reduced by using force-commutated pulse-width modulated inverters. If line-commutated inverters or induction generators are used, the placement of capacitors to supply the reactive power consumed by the inverters must be done carefully, taking into account the amplification of harmonics produced by the inverters. To minimize harmonic distortion, electric utilities may also need to change the order in which existing capacitors on the distribution system are switched on and off.

Long-term concerns for electric utilities. In the long term, higher penetrations of both smalland large-capacity DSG devices may be interconnected to the distribution system. Higher penetrations of DSG devices will increase the complexity of controlling, protecting, and maintaining 
the distribution system. Further, the complete integration of this new tochnology will probably involve design, structural, and facility changes as well as more sophisticated control and protection.

An automation system can provide an integrated system for controlling, munitoring, and protecting the distribution system with DSG. Advanced microprocessor-based equipment placed within the substation and along distribution feeders at sectionalizers, capacitor banks, feeder switches, eic., could provide the necessary control, monitcring, and protection functions. This modular approach to protection and control would allow functions to be selected for each specific application, allow gradual incorporation of automation functions as needs of the distribution system changed, and allow separation of control, protection, and monitoring functions depending on specific performance and reliability requirements. Radio, telephone, nonsynchronous power line carrier, and dedicated cable are communication options for linking the substation and feeder control points.

In summary, electric ntilities can avommodate low penetration levels of DSG in the distribution system in the short term by making the operational, safety, and protection changes necessary for each specific case using conventional hardware and practices. With a low penetration of DSG, most protection, safety, and power quality concerns associated with this technology can be corrected by minor hardware changes or additions without the requirement for sophisticated control schemes.

In the long term, electric utilities will navd to integrate the operation of high penetrations of both small- and large-capacity DSG installations in the electric distribution system. This will require greater communications on the distribution system between power quality equipment and protection hardware as wcll as greater control of beth distribution equipment and DSG devices. Computer-based equipment, such as microprocessor-based control and protection packages, at the DSG installations and at voltage regulators, reclosers, and other distribution operation and protection equipment can provide the necessary control and flexibility for different loading and generation situations. However, the operation and control of DSG devices need to be factored into these technologies in order to achieve complete integration of DSG by developing computer-based technology that provides multiple and adaptable protection and control functions for DSG systems.

\subsubsection{Building Thermal Envelope Systems and Insulating Moterials}

\subsubsection{Thermal mase}

\section{J. E. Christian, G. E. Courville}

Present standards such as ASHP.AE 90A-1980, the DOE Model Code (NBSBCS), and the HUD Minimum Property Standards place heavy emphasis on the thermal resistance of building insulation without adequate consideration of the effects of building thermal mass. However, for cooling heat gain calculations, a design equivalent temperature difference is specified with reference to the thermal time constant of the envelope to account for mass effects. Heating criteria are based strictly on a $U_{0}$ factor, which is an envelope heat transfer coefficient that includes windows, doors, and skylights but not thermal mass. The $U_{0}$ concept is valid only when the steady-state conduction heat loss is the major factor for the building heating energy requirement.

Recent experiments, carried out at the National Bureau of Standards (NBS) and New Mexico Energy Research and Development Institute (NMERDI) under the DOE/ORNL Thermal Mass Program, show that this is not the case for high-mass buildings when the diurnal swing in ambient temperature provides periods when the ambient temperature is alternately above and below the inside setpoint temperature. For example, heat loss calculations for single-room cells in 
Gaithersburg, Maryland, based on the envelope $U_{o}$ are in errnt by as much as 35\% during the spring/fall transition seasons. While this is a significant error, ihe impact on annual heat loss in this case is considerably less because the steady-state assumption is very nearly valid during the winter season, and winter heat 'oss in Maryland and New Mexico is considerably larger than that during transition seasons. Thus the overall heat loss calculated under the steady-state assumption is within a few percent of the measured heat loss. ${ }^{17}$

Separate, independent experimental data consistency checks were run by Francisco Arumi-Noe at the University of Texas using DEROB on the NBS data and by Howard McLain at ORNL using DOE 2.1A on the NMERDI data. For the most part, available large computer mainframe building thermal simulation models confirm the thermal mass effects observed experimentally. Careful matching of experimental data with theory required two-dimensional heat transfer modeling capabilities in some building simulations with heavy-mass walls and footings. Most popular building simulation models handle envelope heat diffusion in only one dimension.

\subsubsection{Roofing research}

\section{G. E. Courville}

The objectives of the ORNL program for low-sloped roofs are to support development of a technology base for achieving optimim use of insulation in roofs and to support the development of an industry-wide capavility for assessing th: thermal performance and durability of insulated roof concepts. The program includes theoretical work, experimental studies, and field investigations.

There are nearly $3.7 \times 10^{9} \mathrm{~m}^{2}$ of low-sloped roofing in the United States, and the annual new construction and replacement activities amount to about $0.3 \times 10^{9} \mathrm{~m}^{2}$ at a cost in excess of $\$ 10$ billion. In a single-story building the roof accounts for as much as 85\% of the above-grade area, and even for three-story buildings the roof is $50 \%$ to $60 \%$ of the area. One estimate for energy savings for improved roofs indicates that, if the average $U$-factor for roofs is reduced from 0.68 to $0.23 \mathrm{~W} / \mathrm{m}^{2} \cdot \mathrm{K}$, the potential savings would be about $0.7 \times 10^{18} \mathrm{~J} /$ year of primary energy.

ORNL has developed a mathematical model for predicting roof surface temperatures under arbitrary environmental conditions; the first application of the model is to predict surface temperature differences over wet and dry insulations. ${ }^{18}$ This work will be important to users of infrared imagers for predicting optimum viewing conditions. For example, Fig. 6.7 shows the contribution of previous-day insolation (a storage effect) on midnight measurements of surface tempcratures over wet and dry insulation for a roof with $5.1 \mathrm{~cm}$ of fibrous glass insulation.

The University of Illinois is under subcontract for the development of a combined thermal, hygric, and mechanical model for roof systerns. This linear model should be useful in fatigue studies. A preliminary report will be available in FY 1984.

ORNL has recently completed construction of a Roof Thermal Research Apparatus (see Fig. 6.8). This fully inst umented facility has space for four $1.2-$ by $2.4 \mathrm{~m}$ roof panels, enabling the staff to carry out several projects simultaneously. Priority will be given to validation of the ORNL and University of Illinois models and to experiments on dynamic effects related to thick insulation and to moisture in roof systems.

ORNL is carrying out a series of studies on roofing research needs. ${ }^{19.20}$ This work is in conjunction with an ongoing feasibility study for a centrally located national user facility. This facility would provide roof researchers with the opportunity to carry out sophisticated experiments on compact roof sections in a fully instrumented, controlled environmental simulator. Priority uses 


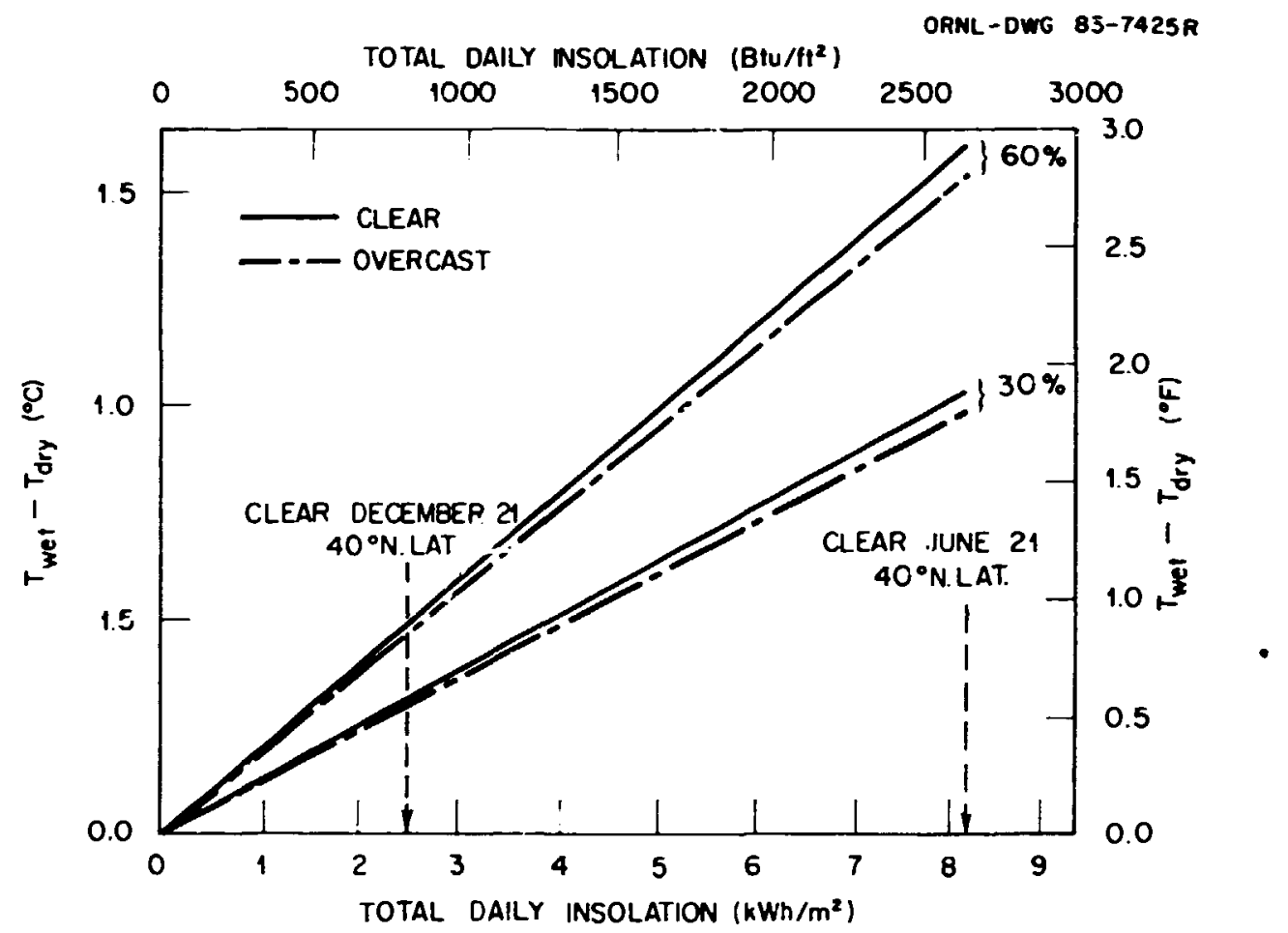

Fig. 6.7. Effect of insolation on surface $\Delta T$ for two ralues $(60 \%$ and $30 \%)$ of roof isoulation moisture content (by rolume).

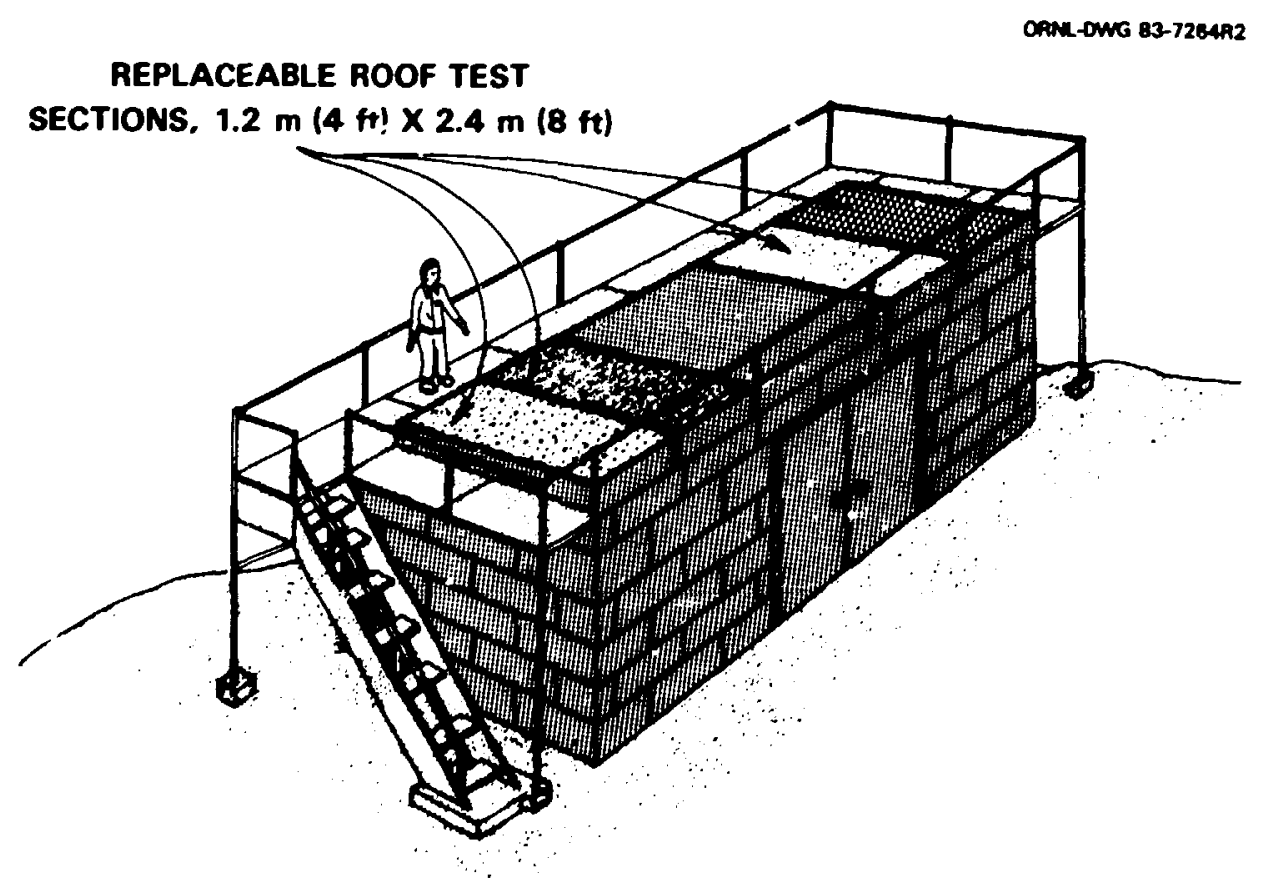

Fig. 6.8. Roofiag Thermal Research Apparatems. 
will include model validation, development of accelerated testing strategies, and testing of new high-thermal-performance roof systems.

ORNL has recently completed a study for the U.S. Air Force on life cycle cost behavior of roof systems using various types of insulations. The study stowed that, for $\mathbb{R}=3.5 \mathrm{~m}^{2} \cdot \mathrm{K} / \mathrm{W}$ roof systems, the life cycle costs were about the same for most commercially available board insulations but that, for higher R-values, foam board insulations tend to have lower life cycle costs. Since material costs incresse and energy costs decrease, there will always be an optimum depending on local conditions. Table 6.4 shows some typical results for the highest cost fuels in three locations.

Talk 6.4. Ecosonically optines instation R levels

\begin{tabular}{|c|c|c|c|}
\hline \multirow{3}{*}{ Location } & \multicolumn{3}{|c|}{ Insulation type } \\
\hline & Fiberboard & Fibrous glass & Isocyanurate \\
\hline & \multicolumn{3}{|c|}{$\mathrm{m}^{2} \cdot \mathrm{K} / \mathrm{W}\left(\mathrm{ft}^{2} \cdot{ }^{\circ} \mathrm{F} \cdot \mathrm{h} / \mathrm{Btu}\right)$} \\
\hline Minot, N. Dak. -oil heat & R-3.5 (R-20) & $R-4.6(R-26)$ & $R-4.6(R-26)$ \\
\hline Phoenix, Ariz -electric heat & $\mathbf{R}-3.7(\mathbf{R}-21)$ & $\mathbf{R}-4.8(\mathbf{R}-27)$ & $R-4.6(R-26)$ \\
\hline Orlando, Fla.-electric heat & R-2.6 (R-15) & $R-3.9(R-2 \hat{Z})$ & R-3.5 (R-20) \\
\hline
\end{tabular}

\subsubsection{Whole building thermal analysis of the Joint Institute Dormitory building}

\section{J. E. Christian}

The Joint Institute Dormitory (JID) building incorporates a number of relatively unique concepts designed to improve some aspect of thermal performance of the building; direct and indirect passive solar collection, thermal storage, earth covering, full-perimete: insulation, economizer-cycle heat pump, and an envelope-integrated HVAC distribution system. The emphasis of this project is not only to collect and report the field thermal performance of individual building components, but also to present evaluation techniques that highlight the interactive effects between envelopes, HVAC systems, comfort, and function.

Figure 6.9 is a bar chart showing t: a average heat gains and losses for a typical winter month. ${ }^{21}$ The largest single heat loss (45\% of he total) is caused by infiltration and a ventilation rate of 0.5 air changes per hour, the minimum recommended for acceptable indoor air quality. To reduce this loss further, a heat exchanger is required to recover some of the vented heat. Examining ineat losses in this manner illustrates the significance of heat transmittance through the envelope components relative to HVAC energy use.

The second largest loss, $25 \%$ of the total, is through the south-facing windows. Reducing this loss calls for a window management system that provides increased insulating capabilities at night. The reflective insulating blinds (RIBs) now installed in the building (but not ins'alled during the time period corresponding to Fig. 6.9) triple the overall window R-ualue.

The heat gain breakdown shown in Fig. 6.9 relates HVAC, building function, and envelope thermal gains to each other. Subtracting window heat losses from solar heat gains leaves a 


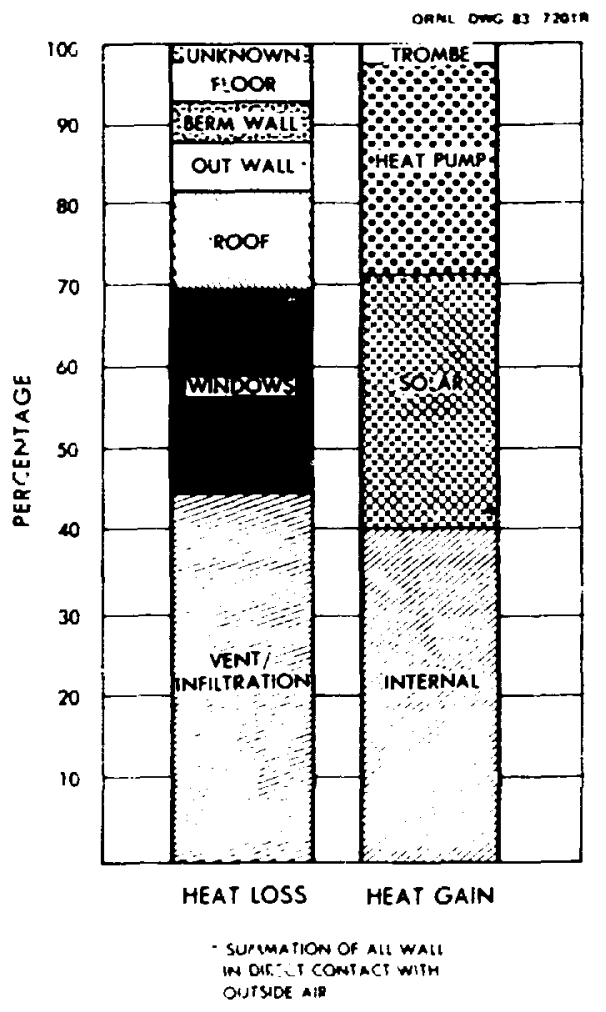

Fig. 6.9. March esergy balance for the Joint Institute Dormitory.

considerably smaller net solar gain. With nighttime window insulation provided by RIBs, the heat pump requirement could be cut in half, and the percent of solar heating in the building could be increased from $55 \%$ to around $75 \%$. Field testing of the RIBs will be ongoing during the 1983-1984 winter.

In the cooling season the building soutn-facing overhang, earth covering, and internal thermal mass combine to keep the cooling cost minimal and thermal comfort acceptable to $90 \%$ of the occupants all of the time as measured by a thermal comfort meter sensing air temperature, mean radiant temperature, and air movement and accounting for humidity, occupant clothing, and metabolism.

The monthly kilowatt-hours required to operate the building HVAC system for cooling correlates well with cooling degree-days. The solar loading is minimal. The roof's thermal impact on the cooling load is just about neutralized. Figure 6.10 shows roof surface temperatures of a conventional roof system compared to temperatures above the insulation on the earth-covered roof and at the upper surface of the earth covering as well as the air temperatures above the roof. The carth absorbs the heat, almost completely shielding the summertime radiant heat gains, a major sensible heat contributor in conventional commercial buildings. The cooling season energy balance is shown in Fig. 6.11.

The whole building has a wintertime thermal integrity factor of $0.016 \mathrm{kWh} / \mathrm{m}^{2} \cdot{ }^{\circ} \mathrm{C}$ $\left(2.8 \mathrm{Btu} / \mathrm{ft}^{2} \cdot{ }^{\circ} \mathrm{F}\right)$. On inc average, the building $\mathrm{HVAC}$ requires $\$ 60$ worth of electricity each month to heat and cool, assuming an electricity cost of $5.7 \mathrm{k} / \mathrm{kWh}$. 


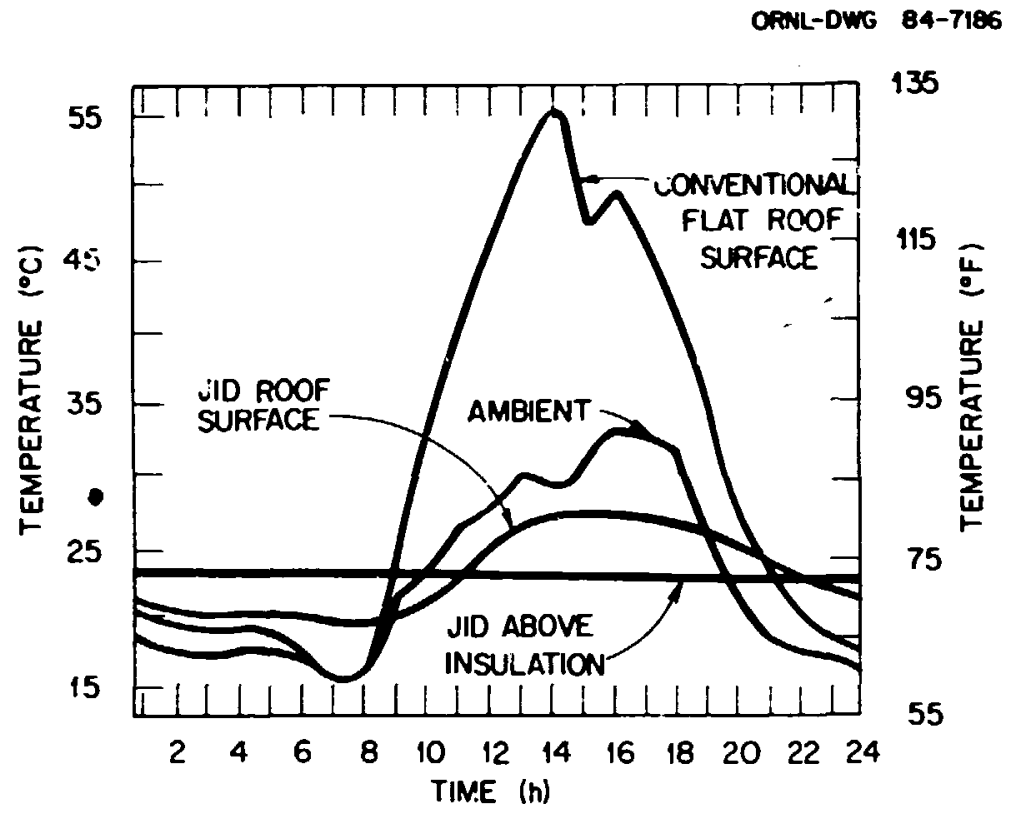

Fig. 6.10. Joint institute Dormitory (JID) roof temperatures compared to those of a conreational roof system.

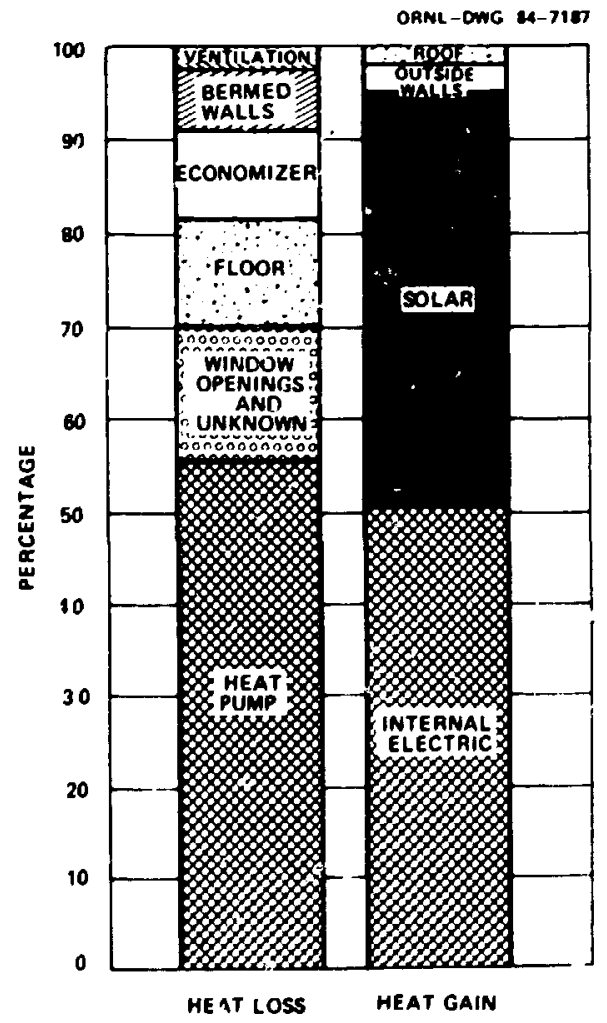

Fig. 6.11. Typical energy balance around Joint Institute Dormitory for the sumaner of 1982. 


\subsubsection{Residential Conservation Service}

\subsubsection{Building retrofit research}

\section{F. D. Boercker, M. A. Karnitz, L. N. McCold, H. A. McLain, M. Olszewski," T. K. Stovall*}

The Residential Conservation Service (RCS) Program was established by DOE as required by the National Energy Conservation Policy Act of 1978. The RCS rules require that large gas and electric utilities offer energy audits to residential customers. An auditor must examine the customer's house and inform the homeowner of the advisability of installing a number : energy conservation and renewable resource measures. Part of the rationaie for this work is based on the fact that building turnover is slow, so upgrading the energy efficiency of existing buildings can heavily impact energy use. Five research tasks were included in this program; these tasks were aimed at improving the understanding of energy and cost savings associated with specific conservation measures. The following is a list of five studies completed in FY 1983:

1. technical review of instlation in crawl spaces, ${ }^{22}$

2. benefits of replacing residential central air-conditioning systems,

3. heat pump desuperheaters for supplying domestic hot water, ${ }^{23}$

4. use of whole-house fans to decrease air-conditioning energy, ${ }^{24}$

5. technical evaluation of add on heat pumps for residential applications. ${ }^{25}$

State government lead :-gencies have the option of adding measures for utilities within their jurisdiction. An example is the add-on heat pump (AOHP), which is a state-added measure in Florida and Wisconsin. The AOHP is a heat pump that is acided to an existing forced-air system of a fossil-fired furnace. Because heat pumps require large air flow rates through the indoor coils, applications of this work were limited to systems that already have central air conditioning and thus adequate flow rates. The heat pump will replace the central air conditioner. The advantage of the AOHP is that the heat pump has a high heating efficiency and capacity in mild weather. Both the efficiency and the heating capacity of the heat pump decline in colder weather, while fossil-fired furnjces have an essentially fixed heating capacity, but their efficiency increases as the outdoor temperature decreases because of lower cycling losses. When the weather is mild, the heat pump part of the AOHP system provides space heating, and, when the weather is cold, the fossil-fired furnace will operate. The temperature at which the switchover from heat pump to furnace occurs is at or near the temperature at which the furnace operates more economically than the heat pump.

The typical cost of an AOHP including installation is approximately $\$ 2,000$ and up. In order for the AOHP to be economically attactive, the annual fuel bill must be significantly reduced. Table 6.5 demonstrates that, even if the AOHP is assumed to require no maintenance or repairs, the simple payback period is extremely long for climates like Miami, Dallas, or Fresno. The reason for the extended simple payback is that these regions have small annual heating fuel bills. If an existing air conditioner requires replacement, then the effective cost of an AOHP can be significantly lower than the $\$ 2,000$ cost mentioned above. For instance, if replacing an existing air conditioner costs $\$ 1,000$, then the effective cost of the AOHP is approximately $\$ 1,000$. This would reduce the simple paybacks listed in Table 6.5 by 50\%. Therefore, the AOHP in colder climates would be attractive when an existing central air conditioner needs replacement.

\footnotetext{
Engineering Technology Division.
} 
Trabe 6.5. Effect of climate on heations seacen suring for an AOHP

\begin{tabular}{|c|c|c|c|c|c|}
\hline City & $\begin{array}{l}\text { Design } \\
\text { temp. } \\
\left.\text { (०) }^{\circ}\right)\end{array}$ & $\begin{array}{c}\text { Annual } \\
\text { base fuel } \\
\text { bill } \\
\text { (5) }\end{array}$ & $\begin{array}{c}\text { Anuual } \\
\text { savings } \\
\text { (I) }\end{array}$ & $\begin{array}{l}\text { Percent } \\
\text { savings" }\end{array}$ & $\begin{array}{c}\text { Simple } \\
\text { payback } \\
\text { period" } \\
\text { (years) }\end{array}$ \\
\hline Miami, Fla. & 3 & 55 & 19 & 40 & 105 \\
\hline Dallas, Tex. & -14 & 458 & 152 & 33 & 13 \\
\hline Fresao, Calis. & -3 & 539 & 169 & 34 & 12 \\
\hline Knoxville, Tenn. & -17 & 676 & 211 & 31 & 9 \\
\hline Washington, D.C. & -14 & 762 & 227 & 30 & 9 \\
\hline Portland, Oreg. & -14 & 910 & 308 & 34 & 6 \\
\hline Seattle, Wash. & -11 & 1004 & 329 & 33 & 6 \\
\hline Chicago, Ill. & -25 & 1094 & 286 & 26 & 7 \\
\hline Denver, Colo.' & -28 & 1127 & 361 & 32 & 6 \\
\hline Syracuse, NY. & -28 & 1206 & 311 & 26 & 6 \\
\hline
\end{tabular}

"These values are based on $26 \% / 1(51.00 / \mathrm{gal})$ oil. $6 \% / \mathrm{kWh}$ electricity, and a house with a heating energy luse rate of $422 \mathrm{~W} /{ }^{\circ} \mathrm{C}$.

these percent savings depend on fuel and electricity prices and fumace and heat putisp efriciencies.

These simple payback periods assume an installed AOHP cost of $\$ 2,000$ and no maintenarce costs.

'Dry winter climate assumed; therefore, no defrost degradation was included.

The cost of fossil fuel and the electric prices are also very important in the economic analysis of heat pumps, as shown in Fig. 6.12. For this example, it is apparent that, if the furnace burns natural gas, there is little advantage to using an AOHP if the electricity is more than about $5 \$ / k W h$. At $6 \$ / k W t$ or less, an AOHP can save more than $\$ 250 /$ year with an oil-burning furnace. In places with very high electric prices, such as states in the northeast, everi a relatively expensive fuel like oil will not make the AOHP attractive.

In summary, an AOHP can save significant amounis of money in cases where the existing furnace is not very efficient and electric prices are not too high. For the ter cities considered (assuming $6 \$ / \mathrm{kWh}$ and $26 \% / 1$ for fuel oil), the annual savings range from 520 to $\$ 360$. Simple paybacks range from 6 to 105 years assuming a $\$ 2,000$ capital investment. However, since a heat pump is a dual-purpose machine, careful consideration should be given to the allocation of capital cost between heating and cooling. For instance, if a central air confitioner needs to be replaced and an AOHP is purchased to replace it, then the annual savings should be compared to the incremental cost of the AOHP ahove the replacement air conditioner.

\subsubsection{Work for Other Government Agencies}

\subsubsection{Nary small cogeneration}

M. A. Karnitz, L. N. McCold

The objective of this project was to evaluate the suitability of - mmercially available small, decentralized, gas-fired c sgeneration systems for buildings on Navy shore bases and to determine 


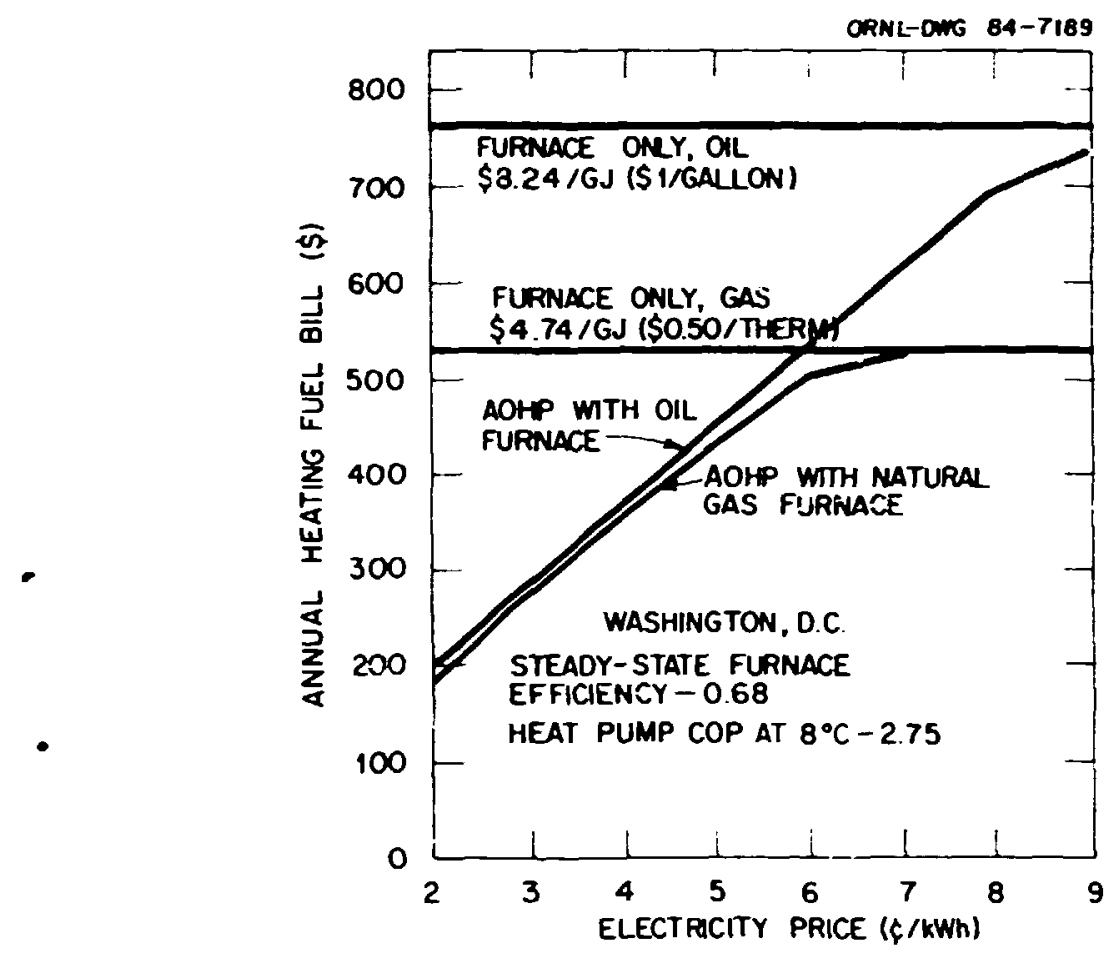

Fig. 6.12. Anowal beatiog facl bills for two fossil fects (and prices) and a range of electricity prices with and withont an AOHP.

their economic value for such applications. In the context of this study, small cogeneration is taken to mean systems with electric generating capacities of $<500 \mathrm{~kW}$. This size range is primarily a reflection of the energy needs of the applications being studied. The decentralized applications being considered involve locating a cogeneration module in or near a building that has substantial need for heat. The heat produced by the module is used to meet part of the building's energy heat needs. Surplus heat is either stored for later use or dissipated by a radiator; it is not distributed to other complexes. By contrast, any surplus electricity generated by the module is exported to other parts of the Navy base.

Three types of applications that are commonly present on Navy bases were investigated: unaccompanied officer personnel housing (UOPH), unaccompanied enlisted personnel housing (UEPH), and hospitals. For these applications, data were gathered at Navy bases in Millington, Tennessee; Pensacola, Florida: Point Mugu, California; and New London/Groton, Connecticut.

The annual savings from operating a cogeneration module equal the value of the heat and electricity produced and credits for avoided capacity charges, minus the cost of the fuel and maintenance to operate the unit. The worth of the cogenerated heat is equal to the cost of the fuel presently used to produce the heat divided by the efficiency of production and delivery of the heat. Table 6.6 lists the economic characteristics of the applications. The importance of electricity price is illustrated by comparing the earnings of the application at Pensacola and Millington. For instance, the hospital application at Pensacola produces $60 \%$ more electricity than the one at Millington, but the electricity produced at the Pensacola hospital is worth twice as much as that produced at the 


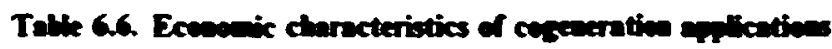

\begin{tabular}{|c|c|c|c|c|c|}
\hline $\begin{array}{l}\text { Application } \\
\text { site }\end{array}$ & $\begin{array}{c}\text { Capital } \\
\operatorname{cost} \\
(S)\end{array}$ & $\begin{array}{c}\text { First-year } \\
\text { savings } \\
\text { (5) }\end{array}$ & $\begin{array}{c}\text { Simple } \\
\text { payback } \\
\text { period } \\
\text { (year) }\end{array}$ & $\begin{array}{l}\text { Savings- } \\
\text { to- } \\
\text { investment } \\
\text { ratio }\end{array}$ & $\begin{array}{c}\text { Net } \\
\text { present } \\
\text { worth } \\
(S)^{b}\end{array}$ \\
\hline \multicolumn{6}{|l|}{ Hospital } \\
\hline $\begin{array}{l}\text { Pensacola, Fla } \\
\text { Millington, Tean. }\end{array}$ & $\begin{array}{r}1: 2,200 \\
\because: 500\end{array}$ & $\begin{array}{r}25,400 \\
7,200\end{array}$ & $\begin{array}{c}5.6 \\
13\end{array}$ & $\begin{array}{l}20 \\
0.9\end{array}$ & $\begin{array}{r}143,800 \\
-13,500\end{array}$ \\
\hline \multicolumn{6}{|l|}{ UEPH } \\
\hline Pensacola, Fle & 58,000 & 10,400 & 5.6 & 21 & 65,100 \\
\hline Millington, Tenn. & 4,000 & 3,000 & 15 & -0.4 & $-19,300$ \\
\hline Groton, Conn. & 112,000 & $-5,800$ & & 1.1 & 14,300 \\
\hline Point Mugu, Calif. & 36,000 & 8.700 & 4.1 & 26 & 55,900 \\
\hline \multicolumn{6}{|l|}{ UOPH } \\
\hline Pensicola, Fla. & 31,000 & 1,200 & 26 & 0.3 & $-22,900$ \\
\hline Millington, Tenn. & 36,000 & -500 & & -0.3 & $-43,300$ \\
\hline
\end{tabular}

-Assuming a 15-year preja. life to DOF's fuel prize earalation factors and a 7\% discount factor.

Electricity value basis: Pensacola, 3.64t/kWh; Millington, 257t/kWh; Groton, $3.86 t / \mathrm{kWh}$; Point Mugu, 6.16t/kWh.

Millington hospital. This is a reflection of the different electricity prices at the two bases. The very low price of electricity at Millington is the reason the net cogeneration earnings are so low there. Also, the capacity credits of Groton's UEPH and Millington's UOPH were reduced because the molule operates substantially less than full time. The economically attractive applications are the hospital and the UEPHs at Pensacola, the UEPH at Groton, and the UEPH at Point Mugu. All of the applications at Millington are unattractive because of the facility's low electricity prices.

In summary, the conditions required for attractive applications of small cogeneration are fairly common on Navy shore facilities. For instance, the electricity prices at Pensacola are not especially high but are sufficient for attractive cogeneration applications. Higher electricity prices can be found in many other parts of the country. In addition, the average minimum heat load requirements are available at many Navy buildings and complexes. Such applications are UEPHs with occupancies of 300 or more. Hospitals, which are found on many Navy bases, have large potential for cogeneration. Other building types such as mess halls may also have large enough average minimum loads to justify use of small, decentralized cogeneration.

\subsubsection{ORNL district beatiog asalydis}

M. A. Karnitz

The ORNL steam district heating system was built in the early 1940s and was modified and expanded in the 1950s and 1960s. A large portion of the system is buried, and recently there have been a rumber of failures in the buried pipelines. This investigation compared the economics of renovating the existing east end system with the esonomics of replacing the east end system with a new hot water system. A decision must be made on the future of this portion of the system since it can no longer be considered reliable. 
The ORNL steam district heating system contains approximately $6.1 \mathrm{~km}$ of aboveground piping and $4.5 \mathrm{~km}$ of underground piping. The major load of the steam distribution system is located at the east end of the Laboratory. The distribution system that serves the east end consists of $3.1 \mathrm{~km}$ of buried piping and about $2.4 \mathrm{~km}$ of aboveground piping. The present steam plant was built in 1948 and was originaily designed to operate on coal. The plant was converted to natural gas and oil in 1950 and reconrerted back to coal in 1980 . The plant produces $1.83-\mathrm{MPa}$ steam, of which 10-15\% is used to drive auxiliaries within the plant and the remaining 85-90\% is exported from the plant to the piping network. Lower-pressure steam $(0.96 \mathrm{MPa})$ is also distributed to some areas of the Laboratory. The east end system primarily serves the building and water heating load. The single largesi user is the $\mathbf{4 5 0 0}$ Building complex. The east end system has significant energy losses resulting from deteriorated insulation, exposure of bare pipe to groundwater, malfunctioning steam traps, general system leaks, and no condensate return. The failure of the old-style conduitenclosed thermal insulated piping is primarily due to corrosion of the conduit casing with subsequent soaking and deterioration of the thermal insulation.

The basic piping network for the new east end hot water system was sized by conventional load/pressure/flow relationships. The piping design is assumed to be based on the well-proven Varme Verks Foreningen (VVF) standards used throughout Europe. The piping generally used in these modern systems consists of two buried steel carrier pipes insulated with a high-density polyurethane foam and jacketed with a high-density polyethylene. The pipe has thin walls (between a schedule 10 and a schedule 20) sufficient to handle the thermal stresses induced by the $121^{\circ} \mathrm{C}$ temperatures. All of the piping system is bonded together, and the polyurethane foam and the polyethylene jacket act to transfer thermal stresses to the surrounding backfill, which is normally a washed sand. The lower temperature allows for the use of cheaper materials such as the polyethylene jacket and the polyurethane foam insulation. The lower temperatures also mean higher operating efficiencies. The direct construction cost of the new hot water system, which includes the piping, a conversion plant, building conversion, and a metering system, is $\$ 4,900,000$.

The economic comparison between the steam renovation and the new not water system includes capital cost, annual fuel cost, and annual maintenance cost. The comparison was limited to the area that is se-ved by the steam system at the east end of the facility. To derive the total capital cost of either the steam renovation or the hot water system, engineering and contingencies were added to the direct construction cost. The total cost including engineering and contingencies of the steam renovation is $\$ 4,160,000$, and the cost for the hot water system is $\$ 7,160,000$. Thus the hot water system opticn has a capital cost of $\$ 3,000,000$ more than the steam renovation. However, the total annual cost, which includes both fuel and maintenance, has a $\$ 540,000$ yearly savings in favor of the hot water option (Table 6.7). The simple payback for the hot water option is 5.5 years. The present worth analysis also favors the hot water option.

In summary, the hot water district heating system for the east end of the ORNL site has many advantages over renovation of the existing steam system. The advantages include good economics, higher reliability, better control, more accurate metering, and a somewhat safer system. Because of these benefits, a new hot water system for the ORNL site was recommended to Laboratory management.

\subsection{RESEARCH UTILIZATION}

An important aspect of research utilization continued to be through the mechanism of subcontracted R \&D wor: to industry, universities, snd other institutions; thus the ultimate user of 
Table 6.7. Sumary of cost comprison (iv doliars)

\begin{tabular}{|c|c|c|c|}
\hline Type of cost & $\begin{array}{l}\text { Steam } \\
\text { renovation }\end{array}$ & $\begin{array}{l}\text { New hot } \\
\text { water system }\end{array}$ & Difference \\
\hline Capital cost" & $4,160,000$ & $7,160,000^{\circ}$ & $3,000,000$ \\
\hline $\begin{array}{l}\text { Annual cost } \\
\text { Fuel } \\
\text { Maintenance }\end{array}$ & $\begin{array}{r}1,848,000 \\
200,000\end{array}$ & $\begin{array}{r}1,458,000 \\
50,000\end{array}$ & $\begin{array}{l}390,000 \\
150,000\end{array}$ \\
\hline Total annual cost & $2,048,000$ & $1,508,000$ & 540,000 \\
\hline $\begin{array}{l}\text { Present worth of annual } \\
\operatorname{cost}(20 \text { years, } 10 \%)\end{array}$ & $17,435,000$ & $12,838,000$ & \\
\hline $\begin{array}{l}\text { Total present worth } \\
\text { (20 years, 10\%) }\end{array}$ & $21,595,000$ & $19,998,000$ & \\
\hline Simple payback period & & & 5.5 years \\
\hline
\end{tabular}

-Includes Engineering at $20 \%$ and contingency at $25 \%$.

'Includes building conversion and other miscellaneous costs.

the new technology is involved directly in its development. During this past year, the Efficiency and Renewables Research Section conducted subcontracted research with approximately 50 industrial companies. In the Building Equipment Research Program, a special effort was made to interact with the appropriate industries to review the DOE program and to obtain their advice and input. Seven such visits to industry were carried out.

As part of the BTESIM Program, interagency/industry tast groups in such areas as insulation, indoor sir nimality, thermal mass, roofing, and diagnostics were formed to transfer technology to the private sector and also to coordinate similar efforts throughout the country. We participate in activities of the Building Energy Committee meetings of the National Institute of Building Sciences and regularly summarize ORNL activities.

In some subcontracts the goal is specifically technology transfer, such as updating Sweet's Catalog, computer models for daylighting, and a simplified computer-aided energy conserving design tool for architects.

In addition, wide dissemination of the work, both subcontracted and in-house, is further achieved by the publication of reports and papers, presentations at technical meetings and workshops (see Chap. 8), and the use of industrial and academic advisory commiftees and consultants. Active participation in several technical srcieties such as the American Society of Heating, Refrigerating, and Air-Conditıoning Engineers; the American Society for Testing and Materials; the American Institute of Architects; the Society of Photo-Optical Instrumentation Engineers; the American Society of Mechanical Engineers; and the Institute of Electrical and Electronic Engineers provides for further industrial interactions and technology transfer.

\subsection{REFERENCES}

1. W. Fulkerson et al., Energy Division Annual Progress Report for Period Ending September 30, 1982. ORNL-5947, Oak Ridge National Laboratory, June 1983.

2. G. Grossman and M. T. Heath, Simulianeous Heat and Mass Transfer in Absorption of Gases in Turbulent Liquid Films, ORNL/TM-8503, Oak Ridge National Laboratory, July 1983. 
3. R. C. Dugan, Computer Simulation Harmonics Stady: Aralysis of the Effects on Two Distribution Feeders of Harmonics Produced by the Propased John F. Long 100-House Photovoltaic Development. ORNL/Sub-81/95011/1, Oak Ridge National Laboratory, August 1983.

4. R. C. Dugan et al., Protection of Electric Distribution Systems with Dispersed Storage and Generation (DSF) Devices, ORNL/CON-123, Oak Ridge National Laboratory, September 1983.

5. Program Plon for Research and Development of Technologies and Systems for Electric Power Systems Under Influence of Nuclear Electromagnetic Pulses. DOE/NBB-0033, U.S. Department of Energy, May 1983.

6. P. R. Achenbach, ed., The National Program Plan for the Thermal Performance of Building Extelope Systems and Materials. ORNI_/Sub-7973/1, Oak Ridge National Laboratory, March 1982.

7. S. K. Fischer and C. K. Rice, A Steady-State Computer Design Model for Air-to-Air Heat Pumps, ORNL/CON-80, Oak Ridge National Laboratory, December 1981.

8. Numerical Analysis Group, NAG Fortran Library, Mark 7. Atomic Energy Establishment, Harwell, England, 1978.

9. Ref. 1, p. 111 , Fig. 6.5.

10. S. K. Fischer and V. C. Mei, "Vertical Concentric Tube Ground-Coil Heat Exchangers," ASHRAE Transactions (in press).

11. S. Johnson et al., Tech House I Horizontal Coil Ground-Coupled Heat Pump: 1982-83 Heatirg Season Performance, ORNL/Sub-81/7685/1 \&92, Oak Ridge National Laboratory, February 1984.

12. P. D. Metz, -Ground-Coupled Heat Pump System Experiment Results," ASHRAE Trans. 89 (Part II-B), 407-415 (1983).

13. W. R. Huntley, "Performance Test Results of an Absorption Heat Pump That Uses Low-Temperature $\left[60^{\circ}\left(140^{\circ} \mathrm{F}\right)\right]$ Industrial Waste Heat," pp. 1921-26 in Proceedings of the $18 \mathrm{th}$ IECEC. Vol. 4, American Ins'itute of Chemical Engineers, New York, 1983.

14. R. C. Dugan, W. T. Jeweli, and D. J. Roesler, "Harmonics and Reactive Power from Line-Commutated Inverters in Proposed Photovoltaic Sutdivision," IEEE Trans. Fower Appar. Syst. PAS-102(9), 3205-11 (September 1983).

15. D. T. Rizy, Personnel Safety Requirements for Electric Distribution Systems with Disptrsed Storage and Generation, ORNL/TM-\$455, Oak Ridg: National Laboratory, November 1982.

16. Systems Control, Inc., Protection and Safety of Electric Distribution Systems with Dispersed Storage and Generation Devices, ORNL/Suh-80/7974/I, Oak Ridge National Laboratory, April 1984.

17. Doug Birch et al., "A Field Study of the Effects of Wall Mass on the Heating and Cooling Loads of Residential Buildings," Proceedings of the Building Thermal Mass Seminar 1982. CONF-8206130, August 1983.

18. K. W. Chiids, G. E. Courville, and P. W. Childs, -An Investigation of Factors Influencing Infrased Roof Moisture Survey Using a Mathematical Model," Proceedings of SPIE-The International Society for Optical Engineering. Vol. 446, An International Conference on Thermal Infrared Sensing for Diagnostics and Control (Thermosense VI). Oct. 2-5, 1983, Oakbrook, Illinois.

19. J. N. Robinson, An Assesssment of Roofing Research. ORNL/TM-7640, Oak Ridge National Laboratory, July 1981 .

20. T. Chang and H. W. Busching. Energy Savings Potential of Rmfing Research, ORNL/Sub-82/22293/1, Oak Ridge National Laboratory. August 1983.

21. J. E. Christian, Thermal Envelope Field Measurements in an Energy-Efficient Office and Dormilory. ORNL./TM-8571, Oak Ridge National Laboratory, April 1983.

22. F. D. Borcker, Technical Review of a Residential Conservation Service Measure: Insulation of Crawl Spaces, ORNL./CON.112, Oak Ridge National Laboratory, January 1984.

23. M. Olszewski and E. C. Fontana, Heat Pump Desuperheaters for Supplying Domestic Hot Water Estimation of Energy Savings and Economic Viability for Residential Applications, ORNL./CON-1/4, ()ak Ridge National Laboratory, May 1983. 
24. M. Otszewsti and H. A. McLain, Using a Whole-House Fan to Decrease Air-Conditioning Energy Use-Estimate of Energy Savings car Ecomomic Viability for Residential Applications, ORNL/CON-115, Oak Ridge National Laboratory, Septereber 1983.

25. L. N. MaCold, Add-On Heat Pumps for Residemtial Applications-Estimation of Savings. ORNL/CON-1 16, Oak Ridge National Laboratory, Januery 1984. 


\title{
7. Integrated Programs
}

\author{
T. J. Wilbanks
}

\subsection{INTRODUCTION}

Durivg FY 1983, the Integrated Programs part of the Division included responsibility for three multisection, multidisciplinary programs: (1) Emergency Preparedness Studies, coordinated by C. V. Chester, (2) International Applications, coordinated by G. Samueis, Jr.; and (3) Social Science Development, an oversight function involving T. J. Wilbanks and the three Section Heads directly concerned with the social sciences (R. M. Davis, A. S. Loebl, and R. B. Shelton). In addition, the Division's Planning and Special Studies Group, consisting of A. M. Perry, G. D. Pine, G. Samuels, Jr., and T. J. Wilbanks, continued to contribute to Division planning and program development, to assist with high-priority projects, and to conduct research and assessment efiorts related to emphases in the Division's Long-Range Plan.

\subsubsection{Energy Analysis}

W. Fulkerson G. Samuels, Jr.
A. M. Perry
T. J. Wilbanks

G. D. Pine

Under the leadership of A. M. Perry, assisted by W. Fulkerson, the Division continued its studies of possible future increases in the concentration of atmospheric $\mathrm{CO}_{2}$ (for earlier results, see refs. 1-4). Under the sponsorship of the Electric Power Research Institute (EPRI), in FY 1983 we considered the possible implications for U.S. electric utilities of a serious international effort to limit the zoncentration of atmospheric $\mathrm{CO}_{2}$.

At present, U.S. utilities contribute only about $8 \%\left(4 \times 10^{14} \mathrm{~g}\right.$ of carbon per year) of total global releases of $\mathrm{CO}_{2}$. Considering a variety of scenarios 'or future electricity generation in the United States in the absence of a worldwide effort to limit the atmospheric concentration of $\mathrm{CO}_{2}$, we found that the projected date for reaching a concentration of $600 \mathrm{ppm}$ was relatively insensitive to fuel choice by U.S. electric utilities (the present level is $338 \mathrm{ppm}$ ). It may be argued, however, that the industrial countries of the world would have to bear a proportionate or larger share of any

\footnotetext{
'Other energy studies during the year addresued such topics as uranium requirements for nuclear energy, structural shifts in U.S. industry as they may affect fuel use, social aspects of the acceptance of auclear energy,' and socioeconomic impacts of U.S. energy use."
} 
restrictions on fossil-fuel use and that, within those countries, sectors with available non-fossil energy options would shoulder most of the load. In such a case, a $\mathrm{CO}_{2}$ limit of 500 to $800 \mathrm{ppm}$ might translate into a total carbon-release "allowance" for U.S. electric utilities of 15 to $75 \mathrm{Gt}$ $\left(10^{15} \mathrm{~g}\right)$ of carbon to be spread over the next hundred years. Allowing for the long useful life of generating stations, together with the lead time needed for their censtruction, this means that U.S. electric utilities might have to begin switching to non-fossil-sueled plants for new construction wittin two decades. This corresponds with the period in wh.. $h$ an upswing in new orders for new generating plasats may be expocted.

\title{
7.1.2 Emergeacy Preparedness
}

\author{
C. V. Chester
}
M. V. Adler
T. W. Reddoch
A. Turhollow
P. R. Barnes
G. Samuels, Jr.
D. P. Vogt
T. R Curlee
J. H. Sorensen
T. J. Wilbanks
K. S. Gant
J. P. Stovall
G. P. Zimmerman
G. K. Hadder

During the year, we maintained a diversified multidisciplinary program of work, involving projects in all five of the Division's sections. These projects addressed emergency preparedness issues ranging from oil supply interruptions to energy facility accidents, radiological emergencies, and civil defense.

Most of the accomplishments are reported in the preceding chapters. For example, we continued our efforts to understand the implications of oil supply interruptions, studying petroleum product supply and demand in U.S. regions under emergency conditions (Chap. 5) and operating an optimal stockpiling model (Chap. 4). We conducted research on emergency planning and response for large energy facilities such as nuclear power plants, considering organizational interfaces in response situations (Chap. 3), human factors in alert classification and off-site notification (Chap. 3), the validity of dispersion models to be used in an emergency (Chap. 2), and population distributions around existing reactor sites (Chap. 2). A growing number of projects were concerned with emergency planning and hazard mitigation related to the handling of hazardous wastes, inciuding alternative routes for shipping hazardous materials (Chap. 3), techniques for monitoring subsurface waste disposal environments (Chap. 2), and a national data base for solving abandoned mine land problems (Chap. 2). We also continued our long-established work in planning for radiological emergencies and civil defense (Chap. 3), expanding the scope of our studies to include analyses of the effects of an electromagnetic pulse on the U.S. power system (Chap. 6).

In addition, two studies were conducted under the auspices of the Planning and Special Studies Group. One study on "When will the next eneigy crisis occur?" is highlighted in Sect. 7.2.2. The other, prepared for the U.S. Department of Energy (DOE) Energy Information Administration, wa: a report by $\mathbf{G}$. Samuels, Jr., summarizing the information presentiy available to support analyses of th. possible impacts of energy supply disruptions in the United States. ${ }^{7}$ Emphasizing petroleum proosets and natural gas, this document provided information on (a) eneigy consumption by fuel 
type, region, sector, and functional use and (b) fuel-switching capability by sector, region, and functional use (in the utijity and manufacturing sectors). It did not estimate the fuel switciing that would actually occur under emergency conditions, but it concluded that the equivalent of at least 22,000 metric tons of oil per day $(160,000$ bbl of oil per day) was being used in dual-fuel electricity generation plants as of 1982 and (based on surveys in 1976 and 1979) that about 61,000 metric tons of oil per day $(450,000 \mathrm{bbl}$ of oil per day) is used in large industrial boilers that could be switched from oil to other fuels.

\title{
7.1.3 International Applications
}

\author{
G. Samuels, Jr.
}
R. W. Barnes
D. L. Groene
W. F. Barron
L. J. Hill
J. E. Dobson
B. F. Hobbs
W. Fulkerson
T. J. Wilbanks

The principal international activity of the Division during FY 1983 was an assessment of energy conditions and options in Liberia, reported in Sect. 7.2.1. In addition, D. L. G1eene of the Transportation Energy Group, Regional and Urban Studies Secion, assisted the government of Tunisia in a study of present energy use and opportunities for energy conservation in the transport sector of that country, under an agreement with the Agency for Intenuational Development (Chap. 3).

\subsubsection{Special Studies}

\section{T. J. Wilbanks}

A. M. Perry

G. Samuels, Jr.

The Integrated Programs part of the Division also helped to meet other needs that arose during FY 1983. For example, it continued to contribute to Oak Ridge National Laboratory's (ORNL's) staf'. sunmort to DOE's Energy Research Advisory Board (ERAB)," and it assisted in an evaluation of the World Integrated Model, a large global forecasting model being considered for use by the U.S. Department of Defense.

In addition, as an invited contributor to a workshop entitled "The Regional Consequences of Large-Scale Energy Projects," organized by the International Institute for Applied Systems Analysis (IIASA), T. J. Wilbanks and R. Lee of the Regional and Urban Studies Section prepared a paper on differences between policy analysis in theory and practice. Drawing on both the published literature and extenive Energy Division experience, as well as other papers prepared for the workshop, the paper suggested several direstions for closing the often sizeable gap between theory and practice. 


\title{
7.2 TECHNICAL HIGHLIGHTS
}

\subsubsection{Assessment of Energy Options for Liberia}

\author{
W. F. Barron \\ L. J. Hill \\ G. Samuels, Jr. \\ R. W. Barnes \\ B. F. Hobbs \\ T. J. Wilbanks \\ J. E. Dobson
}

Since the late 1970s, the economy of the West African country of Liberia (Fig. 7.1) has been declining at a rate of about 5\% per year because of a reversal of the country's import-export balance. The major reason for this reversal has been the rising cost of oil imports-now equal to one-fifth the value of Liberia's gross domestic product (GDP), more than ten times the cost a decade before (in constant dollars). One consequence of the country's increasingly severe cconomic problems has been a sizeable increase in aid from the United States, since the United States maintains a special relationship with Liberia and wants to help keep it stable and viable as a nation.

The challenge to energy policy in Liberia is to help reduce this pressure on the economy; and the Agency for International Development, together with the government of Liberia, asked ORNL

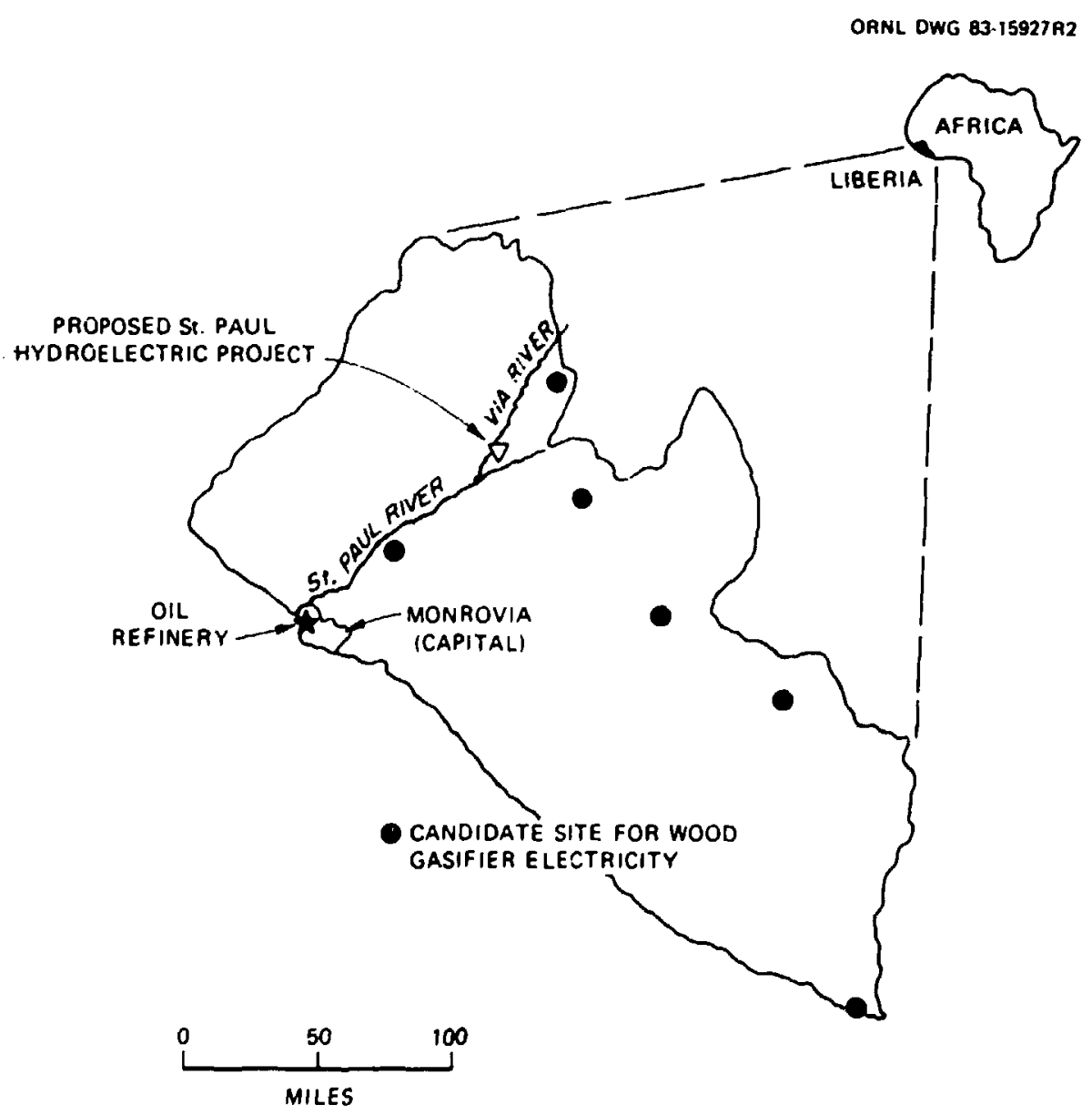

Fig. 7.1. Ubertan emergy option. 
to lead an effort to improve the base of information for meeting this challenge. Accordingly, a oneyear national energy assessment was conducted in 1982-1983 by mcmbers of ORNL's Energy Division, sspported by consultants from universities and the private sector, working with a team of Liberian colleagues.

The assessment resulted in 18 working papers, plus a variety of ad hoc analyses to help answer energy policy questions during the year and a summary report of the information collected and evaluations performed. ${ }^{10}$ Among the conciusions were the following:

1. Liberia has a substantial potential to displace imported oil by making more use of abundant domestic energy resources. Rather than the very large-scale hydroelectric facilities that the country had been considering, the assessment recommended a focus on the country's abundant resource potential in woody biomass. Sixty percent of Liberia's oil imports are used to fuel stationary internal combustion engines, lárgely to generate electricity. Wood gasification appears to be an especially attractive alternative for these engines because proven technologies are available at a variety of scales and levels of scphistication and because they allow wood to be utilized in connection with the engines already in service.

2. Liberia can realize a significan: public revenue windfall by shutting down its oil refinery and importing refined products in place of crude oil. The net revenue benefit was estimated to be \$15-20 million per year (equivalent to about one-quarter of the current annual level of U.S. aid to the country or about $2 \%$ of the country's GDP).

Both of these conclusicas had immediate impacts on energy policy in Liberia. In addition, the assessment led to the beginnings of a national energy conservation policy the transformation of Liberia's National Energy Committee from a fledgling institution into the nation's paramount agency for energy policy discussions, and a notable increase in the interest of international organizations in helping Liberia solve its energy problems.

\title{
7.2.2 When Will the Next Energy Crisis Occur?
}

\author{
D. E. Kash" \\ E. C. Fox ${ }^{\dagger}$ \\ T. J. Wilbanks
}

From the experience of the past decade, it seems that energy as a public policy issue shifts frequently (and often rapidly and unexpectedly) between being classified as a relatively minor concern and an overriding national preoccupation. The result is a disruptive series of stops and starts in energy policy which ser:ously complicates institutional planning in an energy R\&D institution such as ORNL. In this current period of relative de-emphasis, then, an important question for ORNL (and national energy policy) is "When will the next energy crisis occur?"

As a visiting schoiat in residence during the summer of 1983, Professor D. E. Kash of the University of Oklahoma led a study to try to answer this question. "The study concluded that a political event or other potential cause of an oil crisis will trigger an emergency only if it is perceived as threatening to reduce world oil production and/or exports below the world

\footnotetext{
University of Oklahoma.

'Program Planning and Analysis Office, ORNL.
} 
consumption level. If the difference between production capacity and consumption is large, we are not at risk; if it is small, we are at risk. It is useful, therefore, to think in terms of a band of risk: a differential between capacity and consumption which is smaller than the oil potentially lost as a result of a range of plausible triggering events.

Clearly, the current perception is that the differential is more than sufficient to buffer the effects on the world energy system of plausible world events. Based on 1982 data, for cnample, it appears that the difference between effective world oil production capacity (less than absolute capacity: e.g., because of the Iran-Iraq war) and consumption is more than 650,000 metric tons per day ( 5 million barrels per day). The questions for national energy policy are: (a) "How much of this surplus would have to disappear before we again enter the band of risk?" and (b) "What trends or conditions might lead to this changed situation?"

An engineering-economic analysis of U.S. oil consumption in the very near future, assutning a rate of economic growth of about $4 \%$ per year, indicated that total oil consumption would rise by about 300,000 metric tons per day ( 2.3 million barrels per day) in three years of economic recovery. In other words, even though certain long-term trends in efficiency improvements continue, recession-related oil consumption decreases disappear (e.g., in vehicle miles traveled), and oil consumption rises (Fig. 7.2). If we assume conservatively that oil use in the rest of the world

OAn-DWG 84-8133

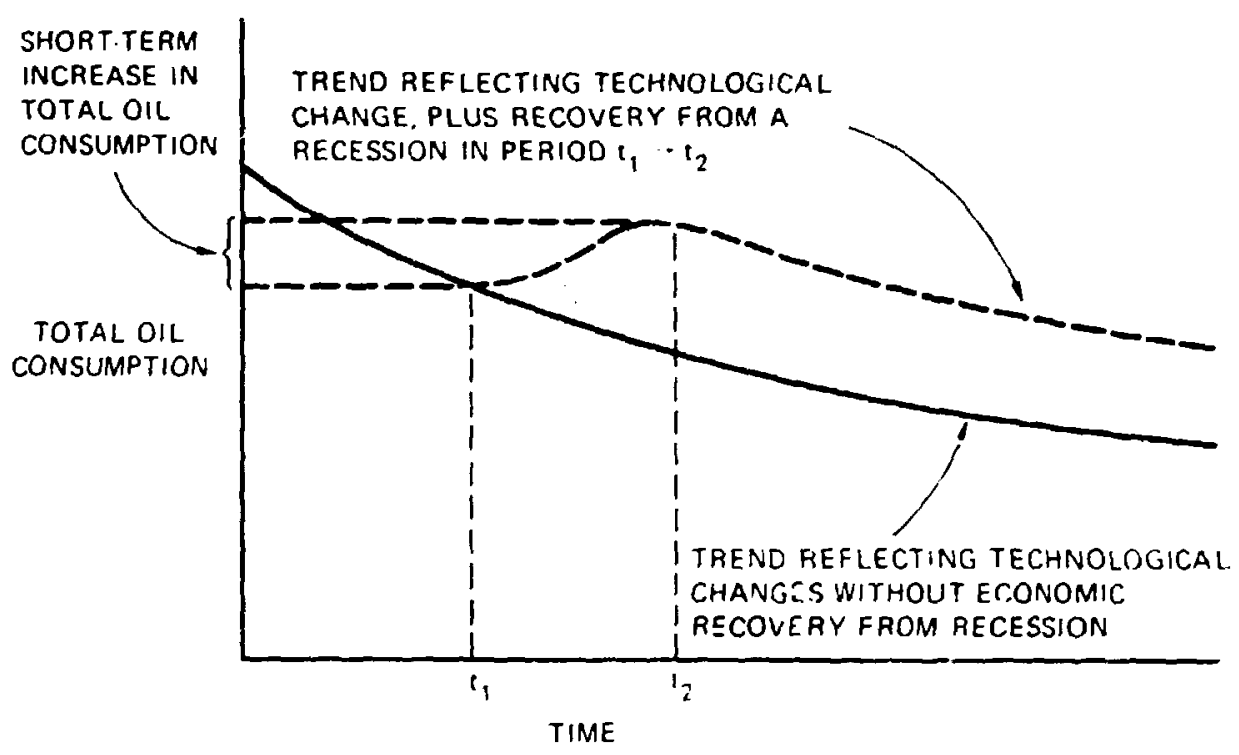

Fig. 7.2. Selvesuntic depiction of the effect of ecomonic recovery on total oll comomption (assuming that, before recovery, oll comevonption bas been reduced by recessionary conditiona)

increases by an absolute amount equal to the U.S. increase (the United States accounts for about one-third of the free world's total oil consumption), the total world consumption level would rise by 600,000 metric tons per day (4.6 million barrels per day) in three years. This would reduce the effective free-world production surplus to less than 1 million barrels per day, certainly within the band of risk. 
Additions to production capacity in non-OPEC free-world oil producing countries are likely to continue, of course, moderating such an effect [these additions amounted to 300,000 metric tons per day (2.2 million barrels per day) in the three-year period 1979-i982]. But the figures on effective capacity assume higher levels of production than several important producers are likely to accept, and other factors are likely to operate as well if economic growth causes the consumption of oil to increase, creating pressures for price increases. For instance. private holders of oil are likely to stop releasing their stocks into the market and to begin replacing them with new purchases, causing demand to outpace consumption. And price hawks among the exporting countries will be tempted to seize on a shrinking surplus as a way te restore the conditions they prefer.

Such an outcome is not certain, to be sure, but it is at least quite possible that, if economic recovery is sustained for as long as three years, the physical conditions will then exist such that a variety of triggering events could cause an oil crisis.

\subsection{RESEARCH UTILIZATION}

Most of the utilization of rescarch conducted in the Integrated Programs area was done by sponsors and the researci community, but several other instances were notable as well. For example, Liberia project reports were used extensively by the World Ban i in planning an energy assessment of its own for Liberia, :o be conducted in FY 1984. The report of thi Committee on Behavioral and Social Aspects of Energy Consumption and Production of the National Acaden y of Sciences/National Research Council, ${ }^{12}$ which incorporated information and materials suppli $x$ by ORNL, ${ }^{13.14}$ was used by several parts of DOE, together with utilities and other parties intere ted in energy use and emergency preparedness. Our contributions to the ERAB studies of na: :nal laboratories were provided, in response to invitations, to broader audiences. ${ }^{15.16}$ In addition, the Planning and Special Studies Group played a special role in integrating the fruits of Division experience to meet the needs of particular interested parties, such as Congressional committees."

\subsection{REFERENCES}

1. W. Fulkerson et al., Energy Division Annual Progress Report for Period Ending September 30. 1980, ORNL-5740, pp. 164-65, Oak Ridge National Laboratory, November 1981.

2. W. Fulkerson et al., Energy Division Annual Progress Report for Period Ending September 30, 1981, ORNL-5872, pp. I 10-113, Oak Ridge National Laboratory, May 1982.

3. W. Fulkerson et al., Energy Division Annual Progress Report for Period Ending September $30,1982$. ORNL-5947, pp. 134-137, Oak Ridge National Laboratory, June 1983.

4. A. M. Perry, K. J. Araj, W. Fulkerson, D. J. Rose, M. M. Miller, and R. M. Rotty, -Energy Supply ard Demand Implications of $\mathrm{CO}_{2}, "$ Energy 7, 991-1004 (1982).

5. T. J. Wilbanks, "Scale and the Acceptability of Nuclear Energy," pp. 9-50 in Nuclear Power: Assessing and Managing Hazardous Technology, Martin J. Pasqualetti and K. David Pijawka, eds., Westview Press, Boulder, Colo., 1984.

6. T. J. Wilbanks, "Geography and Our Energy Heritage," Materials and Soclety 7, 437-52 (1983); reprinted in Energy in American History, A. Donovan, ed. (to be published).

7. G. Samuels, Jr., Dato Availability and Limitations for the Analysis of Energy Supply Disrupilons, ORNL-5977, Oak Ridge National Laboratory, February 1984. 
8. T. J. Wilbanks, "Relationships Between Universities and the DOE Laboratories" pp. 33-49 in An Assessment of the Relationships Between the Department of Energy and Universities and Colleges. DOE/S-0025, Vol. II, U.S. Department of Energy, October 1983.

9. T. J. Wilbasks and R. Lee, "Policy Analysis in Theory and Practice," in Assessing Regional Consequences of Large Scule Energy Projects. T. R. Lakshmanan et al., eds (to be pablisbed).

10. W. F. Barron, M.-H. Neufville, at al, An Assessment of Energy Options for Liberia, CRNL-5989, Oak Ridge National Laboratory, November 1983.

11. D. E Kash, E. C. Fox, and T. J. Wilbanks, -When Will the Next Energy Crisis Oocur?" Oil and Gas J. 81/51, 82-91 (Doc. 19, 1983).

12. Energy Use: The Human Dimension, Report of the Committee on Behavioral and Social Aspects of Energy Consumption and Production, National Acadeny of Sciences/National Research Council. W. H. Freeman, Sen Francisco, 1984.

13. W. Fulkerson et al., Energy Division Annual Progress Report for Period Ending September 30, 1981, ORNL-5872, Oak Ridge Natioaal Laboratory, May 1982

14. W. Fulkerson et al., Energy Division Annual Progress Reporn for Period Ending September 30, 1982, ORNL-5947, Oak Ridge National Laboratory, June 1983.

15. T. J. Wilbanks, "Institutional Choices and Linkages in the New R \&D Partnership," presented at the Symposium on National Science and Technology Policy, American Society for Public Administration, New York, Apr. 16-18, 1983.

16. H. Lambright, A. Teich, and T. J. Wilbanks, "The Future Role of Government Laboratories," presented at the Seminar Series on the Changing Structure of the U.S. Research System, George Washington University, Washington, D.C., May 18, 1983.

17. T. J. Wilbanks, testimony to the Subcommittee on Energy Development and Applications of the U.S. House Committee on Science and Technology, Mar. 10, 1983. 


\section{Publications, Presentations, and Professional Activities}

\subsection{ADVISORY COMMITTEE}

The Advisory Committee for the Energy Division is appointed by Herman Postma, Director of Oak Ridge National Laboratory. The committee members for FY 1983 were as follows:

\author{
Todd R. LaPorte, Chairman \\ Professor, Political Science \\ Institute of Government Studies \\ University of California \\ 109 Moses Hall \\ Berkeley, California 94720 \\ Fritz R. Kalhammer \\ Vice President \\ Electric Power Research Institute \\ P.O. Box 10412 \\ Palo Alto, California 94303
}

\author{
Stephea V. Kaye \\ Director, Health and Safety \\ Research Division \\ Oak Ridge National Laboratory \\ P.O. Box X \\ Oak Ridge, Tennessee 37831 \\ Laurence I. Moss \\ Energy/Environmental Design and \\ Policy Analysis \\ 5769 Longs Peak Route \\ Estes Park, Colorado 80517
}

William H. Williams
Division Manager
AT\&T Information Systems
100 Southgate Parkway
Building 8j, m I B23
Morristown, New Jersey 07960

\subsection{PUBLICATIONS BY ENERGY DIVISION STAFF}

Adler, M. V., " $\Gamma$ - - دster Dilemma: Emergency Energy," J. Civil Defense 16(2), 18 (April 1983).

Arnold, H. G., "Artifacting with Graphics 7-Plus," The Creative Atari, eds. D. Small, S. Small, and G. Blank, Creative Computing Press, Morris Plains, N.J., 1983.

Baldwin, J. S., S. A. Carnes, C. C. Gilmore, R. H. Ketelle, F. C. Kornegay, D. W. Lee, J. H. Reed, and W. P. Staub, "Low-Level Radicactive Waste Management Handbook Series," Procedures and Technology for Shallow Land Burial, National Low-Level Radioactive Waste Management Program, Idaho Falls, Idaho, DOE/LLW-13Td, U.S. Department of Energy, August 1983. 
Barnes, P. R.. Program Plan for Research and Development of Technologies and Systems for Electric Power Systems Under the Influence of Nuclear Electromagnetic Pulses. DOE/NBB-0033, U.S. Department of Energy, M2y 1983.

Barth, W. S., M. A. Karnitz, H. A. McLain, B. D. lacano, and D. E. White, Anclysis of Akron, Ohio, Steam District Heating Distribution Nerwork, ORNL/TM-8173, Oak Ridge National Laboratory, June 1982*

Baxter, V. D., ACES Tests at the TECH Site, ORNL/CON-96, Oak Ridge National Laboratory, August 1983.

Baxter, V. D., -Heat-Pump Efficiency: How Good a Guide Are the Ratings?" pp. 4-5 in Lab News, Oak Ridge National Laboratory (November 1982).

Baxter, V. D., L. A. Abbatiello, and R. E Minturn, -Comparison of Field Performance to SteadyState Performance for Two Dealer-Installed Air-to-Air Heat Pumps," ASHRAE Trans. 88(2), 941-53 (1982).

Berry, L G., Methnds of Reducing Self-Seloction Bias in the Interpretation of Residential Conservation Program Impacts," Evaluation Review, accepted for publication.

Berry, L. G., "The Role of Financial Incentives in Utility-Sponsored Residential Conservation Programs: A Review of Customer Surveys," Evaluation and Program Planning: An International Joumal, accepted for publication.

Berry, L. G., and E. Hirst, Evaluating Utility Residential Energy Conservation Programs: An Overview of an EPRI Workshop," Energy Policy 11(1), 77-81 (March 1983).

Berry, L. G., and K. E. Johnson, Evaluations of Utility Residential Conservation Programs in the Pacific Northwest: A Critical Review," Public Utilities Fonnightly. accepted for publication.

Berry, L. G., H. Tsao, and E. Hirst, Design Options to Test the Effects of Financial Incentives in a Utility Conservation Program: TVA's Heat Pump Water Heater Program, ORNL/CON-125, Oak Ridge National Laboratcry, July 1983.

Berry, L. G., The Role of Financial Incentives in Utility-Sponsored Residential Conservation Programs: A Review of Customer Surveys, ORNL/CON-102, Oak Ridge National Laboratory, December 1982.

Bjornstad, D. J., D. N. Stuckwish, and J. B. Mills, -The Impact of a Major Crude Oil Curtailment on Regional Employment," J. Energy Syst. Pol. 6(4), 291-313 (1982).

Bjornstad, D. J., and D. P. Vogt, "Some Comments Relating to Model Specification on Effects of Nuclear Power Plants on Residential Property Values," Jourmal of Regional Science, accepted for publication.

Bjornstad, D. J., and R. C. Tepel, Commercial and Apartment Conservation Service Regulatory Impact Analysis, DOE/CE-0051, U.S. Department of Energy, July 1983.

Bjornstad, D. J., E. L. Hillsman, R. C. Tepel, J. B. Mills, C. V. Chester, O. H. Klepper, R. J. Borkowski, J. Nichols, and J. A. Rainey, The On-Farm Use of Biomass Fuels: Market Penetration Potential During Normal and Fuel Emergency Conditions, ORNL-5894, Dak Ridge National Laboratory, December 1982.

Blumberg, R., J. B. Cannon, G. S. Hill, R. H. Ketelle, D. W. Lee, and F. G. Pin, GCEP Waste Pathways Analysis Study, K/D-5375, Oak Ridge Gaseous Diffusion Plant, January 1983.

- Omitted from FY 1982 report. 
Boercker, F. D., L. F. Menendez, and L. M. Frogge, Basic Considerations for Mcnitoring and Evaluating the Residential Conservation Service, ORNL/CON-98, Oak Ridge National Laboratory, November 1982.

Borkowski, R. J., T. K. Stovall, and M. A. Karnitz, New District Heating System Economic Factors Vary with Different Supply Temperatures, ORNL/TM-8513, Oak Ridge National Laboratory, October 1982.

Boyle, J. W., R. Blumberg, S. J. Cotter, G. S. Hill, C. R. Kerley, R. H. Ketelle, R. L. Kroodsma, D. W. Lee, R. C. Martin, R. D. Roop. D. N. Secora, W. P. Staub, and R. E. Thoma, Environmental Analysis of the Operation of Oak Ridge National Laborctory (X-10 Site), ORNL-5870, Oak Ridge National Laboratory, November 1982.

Brantley, V. R., Feasibility of an Uncomventional Heat Flow Measuring Technique to Determine Coefficient of Performance on Installed Heat Pumps, ORNL/TM-8587, Oak Ridge National Laboratory, January 1983.

Bronfman, B. H., S. A. Carnes, and R. S. Ahmad, "Community-Based Technology Assessment: Four Communities Plan Their Energy Future," in Integrated Impact Assessment, ed. F. A. Rossini and A. L. Porier, Westview Press, Boulder, Colo., 1983.

Cannon, J. B., C. E. Easterly, C. C. Gilmore, and R. E. Thoma, Action Description Memorandum-Coniaminated Scrap Metal Waste Management, Sorting and Size Reduction, K/D-5481, Oak Ridge Gaseous Diffusion Plant, Aug. 10, 1983.

Cannon, J. B., W. Dayis, Jr., C. E. Easterly, H. E. Goeller, G. S. Hill, J. R. McNally, Jr., R. T. Santorn, J. B. Talbot, J. S. Watson, and F. W. Wiffen, Background Information and Technical Basis for Assessment of Environmental Implications of Magnetic Fusion Energy. DOE/ER-0170, U.S. Department of Energy, August 1983.

Cantor, S., M. P. Stulberg, and E. C. Halbert, Alternate Fuels Information Requirements Review-Final Report, U.S. Department of Energy, Sept. 30, 1983.

Carnes, S. A., E. D. Copenhaver, J. H. Sorensen, E. J. Soderstrom, J. H. Reed, D. J. Bjornstad, and E. Peelie, "Incentives and Nucicar Waste Siting: Prospects and Constraints," Energy Syst. Policy 7(4), 323-51 (1983).

Carson-Henry, C., E. A. Fosnight, D. B. Hunsaker, Jr., and R. M. Moreland, ABAG Biogenic Hydrocarbon Emissions Inventory Project, Final Report. NASA Contractor Report 166498, NASA Ames Research Center. Moffet Field, Calif., August 1983.

Chen, F. C., and A. Golshani, A Study of Hydraulic Air Compression for Ocean Thermal Energy Conversion Open-Cycle Applications, ORNL/TM-838:. Oak Ridge National Laboratory, January 1983.

Chester, C. V., "Book Review. BORN SECRET-The H-Bomb, the Progressive Case and National Security," Nuclear Science and Engineering Journal, accepted for publication.

Childs, K. W., "The Influence of Thermal Mass on Building Energy Usage," pp. 1. 10 in Proceedings of the Building Thermal Mass Seminar 1982, ed. G. E. Courville and E. L. Bales, CONF-82061 30, Oak Ridge National Laboratory, August 1983.

Childs, K. W., G. E. Courville, and E. L. Bales, Thermal Mass Assessment, ORNL/CON-97, Oak Ridge National Laboratory, September 1983.

Christian, J. E., "Thermal Envelope Field Measurenients in an Energy-Efficient Office/Dormitory," pp. 297-324 in ASHRAE/DOE Conference-Thermal Performance of the Exterior Envelopes of Buildings II, ASHRAE, Inc., New York, 1983. 
Christian, J. E., Thermal Envelope Field Measurements in an Energy-Efficient Office and Dormitory, ORNL/TM-8571, Oak Rióge National Laboratory, April 1983.

Collins, N. E, J. H. Reed, and R. B. Braid, A Systematic Review of Approaches to Assessing Energy Conservation Program (SECP and EES) Impacts, ORNL/TM-87?1, Oak Ridge National Laboratory, July 1983.

Collins, N. E., L. N. McCold, and P. Zuschneid, Thermal Efficiency Standards and Codes, Volume I: State-of-the-Art Literature Review and Analysis of Secondary Data, ORNL/CON-101/V1, Oak Ridge National Laboratory, June 1983.

Copenhaver, E. D., S. A. Carnes, E. J. Soderstrom, J. H. Sorensen, E. Peelle, and D. J. Bjornstad, "Review of Institutional and Socioeconomic Issues for Radioactive Waste Repository Siting," Advances in the Science and Technology of the Management of High-Level Nuclear Waste, ed. P. L. Hofman, Battelle Memorial Institute, Columbus, Ohio, accepted for publication.

Courville, G. E, "Professionalism in Commercial Infrared Sensing-An Update," pp. 32-36 in Thermal Infrared Sensing Diagnostics (Thermosense V). Proceedings of SPIE 37I, The International Society for Optical Engineering, ed. G. E. Courville, Bellingham, Wash., April 1983.

Courville, G. E., and E. Bales, eds., Proceedings if the Building Thermal Mass Seminar-1982, CONF-8206130, Oak Ridge National Laboratory, August 1983.

Courville, G. E., ed., Thermal Infrared Sensing Di gnostics (Thermasense V). Proceedings of SPIE 371, The International Society for Optical Engineering, Bellingham, Wash., April 1983.

Creswick, “Gas Heat Pump Development," pp. 149-57 in Proceedings, International Gas Rese urch Conference, Government Institutes, Inc., 1982.

Curlee, T. R., "Strategic Stockpiie Acquisitions and the Current World Oil Market," Energy Policy, accepted for publication.

Dobson, J. E., "Automated Geography," The Professional Geographer 35(2), 135-43 (May 1953).

Dobson, J. E., "Reply to Comments on Automated Geography," The Professional Geographer 35(3), 349-53 (August 1983).

Eksel, M., W. G. Sullivan, G. D. Pine, and M. A. Karnitz, An Economic Evaluation of End-User Conservation Measures Applied to Buildings Served by a Proposed District Heating System, ORNL/TM-8277, Oak Ridge National Laboratory, May 1982."

Fairchild, P. D., and C. D. West, "Heat-Activated Heat Pump Development and Potential Application of Stirling Engine Technology," pp. 17-31 in Proceedings of 20th Automotive Technology Development Contractor Coordination Meeting. CONF-821055-1, Society of Automotive Engineers, New York, 1982.

Fischer, S. K., and M. L. Ballou, EZJCL: A PDP-10 MIC Program to Generate DISSPLA JCL, ORNL/CSD/INF-83/1, Oak Ridge National Laboratory, Afril 1983.

Fischer, S. K., D. M. Hetrick, M. H. Lietzke, A. H. Eraslan, K. H. Kim, and M. R. Patterson, CHMONE: A One-Dimensional Computer Code for Simulating Temperature, Flow, and Chemical Concentrations in Water Bodies, ORNL/TM-8786, Oak Ridge National Laboratory, July 1983.

Fulkerson, W., T. J. Wilbanks, H. E. Zittel, R. M. Davis, R. B. Shelton, A. S. Loebl, and J. W. Michel, Energy Division Annual Progress Report for Perlod Ending September 30, 1982, ORNL-5947, Oak Ridge National Laboratory, June 1983.

- Omitted from FY 1982 report. 
Fullerton, A. M., E. Peelle, and J. H. Reed, An Evaluation of the Nuclear Power Plant Operator Licensing Examiration: Final Report. NUREG/CR-3458, ORNL/TM-8895, Oak Ridge National Laboratory, August 1983.

Gant, K. S., "Annual Doses from Varying Annual Intake of "Sr" (Research Note), Health Physics, accepted for publication.

Gant, K.. S., and C. V. Chester, -Will Radiation-Induced Cancer Kill All the Survivors of a Nuclear War?" Pract. Civ. Def. 1(1), 26 (1983) (Reprinted from the Journal of Civil Defense, March/April 1983).

Gellings, C. W., J. R. Redmon, J. P. Stovall, and T. W. Reddoch, "Eloctric System Impacts of Storage Heating and Storage Water Heating-Part I of Two Parts," IEEE Trans. Power Appar. Syst. PAS-101, 2068-76 (1982).

Gellings, C. W., J. R. Redmon, J. P. Stovall, and T. W. Reddoch, "Electric System Impacts of Storage Heating and Storage Water Heating-Part II of Two Parts," IEEE Trans. Power Appar. Syst. PAS-101, 2077-85 (1982).

Gilliland, D. C., J. E. Boyer, Jr., and H. J. Tsao, "Bayes Empirical Bayes: Finite Parameter Case," Ann. Stat. 10(4), 1277-82 (1982).

Greene, D. L., E. Hirst, E. J. Soderstrom, and J. L. Trimble, Estimating the Total Impact on Energy Consumption of DOE Conservation Programs, ORNL-5925, Oak Ridge National Laboratory, November 1982.

Greene, D. L., “A Derived Demand Model of Regional Highway Diesel Fuel Use," Transportation Research, accepted for publication.

Greene, D. L., "A Note on Implicit Consurner Discounting of Automobile Fuel Economy: Reviewing the Available Evidence," Transp. Res. 178(6), 491-99 (1983).

Greene, D. L., "Highway Fuel Use: Trends and Factors," Proceedings of the Symposium on Petroleum Supply Information, Arlington, Virginia, DOE/EIA-0425, Energy Information Administration, U.S. Department of Energy, August 1983.

Greene, D. L., "Regional Demand Implications for Gasoline Supply Shortages," pp. 206-33, in Systems and Models for Energy and Environmental Analysis, ed. T. R. Lakshmanan and P. Nijkamp, Gower, United Kingdom, 1983.

Greene, D. L., "Streamlining the Collection and Processing of Traffic Count Statistics: A Comment," Transportation Research Record, accepted for publication.

Greene, D. L., P. S. Hu, and G. F. Roberts, “An Analysis of Geographical and Temporal Variation in Vehicle Classification Count Statistics," Transportation Research Record, accepted for publication.

Greene, D. L., R. Barnes, R. Lee, and TERA Associates, An Overview of the Whanion School Assessments of the Short-Term Integrated Forecasting System, DOE/NBB-0046, Energy Information Administration, U.S. Department of Energy, July 1983.

Greene, D. L., and C. K. Chen, “A Time Series Analysis of State Gasoline Demand, 1975-80,” The Professional Geographer 35(1), 40-51 (February 1983).

Greene, D. L., and G. F. Roberts, "A Comment on Fuel Consumption for Road Transport in the U.S.A.," Energy Economics, in press.

Greene, D. L., and P. S. Hu, "Vehicle Usage in Multi-Vehicle Households and the Price of Gasoline," Transportation Research Record, accepted for publication. 
Grossman, G., -Adiabatic Absorption and Desorption for Improvement of Temperature-Boosting Abscrption Heat Pumps," ASHRAE Trans. 8(1), 359-67 (1982).

Grossman, G., Adiabatic Absorption c:ul Desorption for Improvement of Temperature-Boosting Absorption Heat Pumps, ORNL/:M-8390, Oak Ridge National Laboratory, November 1982

Grossman, G., E. Fruchter, and F. Urieth, "Development and Testing of a Stationary Reflector/Tracking Absorber Solar Collector for Intermediate Temperatures,"J. Sol. Energy Eng. 104, 340-44 (1982).

Grossman, G., and K. W. Childs, "Computer Simulation of a Lithium Bremide-Water Absorption Heat Fump for Temperature Boosting," ASHRAE Trans. 8\%(1B), 240-48 (1983).

Grossman, G., and M. T. Heath, Simultaneous Heat and Mass Transfer in Absorption of Gases in Turbulent Liquid Films, ORNL/TM-8503, Oak Ridge National Laboratory, July 1983.

Hamblin, D. M., R. C. Tepel, D. J. Bjornstad, L. J. Hill, R. A. Cantor, P. J. Carroll, S. M. Cohn, G. R. Hadder, B. D. Holcomb, K. E Johnson, C. G. Rizy, B. Thomas, Jr., B. Tonn, and A. F. Turhollow, Clinch River Breeder Reactor (CRBR): An Assessment of Need for Power and Regulatory Issues, ORNL/TM-8892, Oak Ridge National Laboratory, September 1983.

Hill, L. J., and V. K. Smith, -The Role of Allocation Functions in Energy Modeling," Resour. Energy, 4, 307-28 (December 1982).

Hillsman, E. L., The p-Median Structure as a Unified Linear Model for Location-Allocation Analysis," Environment and Planning $A$, accepted for publication.

Hillsman, E. L., D. R. Alvic, and R. L. Church, BUILD (Baseload Utility Integrated Location Decisirns): A Model of the Future Spatial Distribution of Electric Power Production, ORNL-5969, Oak Ridge National Laboratory, June 1983.

Hirst, E., B. H. Bronfman, R. T. Goeltz, J. L. Trimble, and D. Lerman, Evaluation of the BPA Residential Weatherization Pilot Program, ORNL/CON-124, Oak Ridge National Laboratory, June 1983.

Hirst, E., J. L. Trimble, R. T. Goeltz, and N. S. Cardell, Methods to Deal with Self-Selection in Estimating Conservation Program Energy Savings: Use of Synthetic Data to Tes: Alternative Approaches, ORNL/CON-120, Oak Ridge National Laboratory, March 1983.

Hirst, E., L. G. Berry, K. E. Johnson, R. C. Tepel, and J. L. Trimble, "Evaluation of Conservation Programs: The BPA Plan," Evaluation and Program Planning: An International Journal. accepted for publication.

Hirst, E.., P. S. Hu, E. F. Taylor, Jr., K. M. Thayer, and S. Groeneman, The Residential Conservation Service in Connecticut: Evaluation of the CONN SAVE Program. ORNL/CON-i32, Oak Kidge National Laboratory, Septembe: 1983.

Hirst, E., R. Marlay, D. L. Greene, and R. W. Barnes, "Recent Changes in U.S. Energy Consumption, What Happened and Why," Ann. Rev. Energy 8, 193-245 (1983).

Hirst, E., R. W. Barnes, S. M. Cohn, K. R. Corum, D. L. Greene, D. M. Ham:blin, G. Kulp, D. B. Reister, and T. A. Vineyard, "Effects of Improved Energy Efficiency on U.S. Energy Use: 1973-1980," Energy 7(11), 897-907 (November 1982).

Hirst, E., and S. Grady, "Evaluation of a Wisconsin Home Energy Audit Program," J. Environ. Syst. 12(4), 303-320 (1982/1983).

Hobhs, B. F., "Multiobjective Approaches to River Basin Planning, Discussion," Proceedings of the American Society of Civil Engineers, Journal of Water Resources Planning and Management. accepted for publication. 
Hobbs, B. F., -Review of Multiobjective Decision Analysis with Engineering and Business Applications," The Engineering Economist, accipted for publication.

Hobbs, B. F., "Water Supply for Power in the Texas-Gulf Region," Proceedings of the American Society of Civil Engineers, Journal of Water Resources Planning and Management, accepted for publication.

Holcomb, M. C., G. F. Roberts, and D. L. Greene, Motor Vehicle MPG and Market Shares Repori, MPG and Market Share Data System, Model Year 1982-Third Quarter 82(1), Oak Ridge National Laboratory, October 1982.

Holcomb, M. C., and G. F. Roberts, Motor Vehicle MPG and Market Shares Report, MPG and Market Share Data System, Model Year 1983-First Six Months, 83(1), Oak Ridge National Laboratory, July 1983.

Honea, R. B., F. P. Baxter, R. C. Durfe, R. G. Edwards, N. S. Fischman, R. W. Peplies, C. H. Petrich, R. M. Rush, K. A. Taft, C. E. Tanner, and D. L. Wilson, A National Inventery of Abandoned Mine Land Problems: An Emphasis on Health. Safety, and General Welfare Imparts, OSM/TR-4/83, Office of Surface Mining, U.S. Department of the Interior, August 1983.

Hooker, J. N., A. B. Rose, and G. F. Roberts, "A Holistic Approach to Vehicle Simulation," Math. Comput. Simulation 25, 259-67 (1983).

Hooker, J. N., A. B. Rose, and G. F. Roberts, "Optimal Control of Automobiles for Fuel Economy," Transp. Sci. 17(2), 146-67 (May 1983).

Hsu, C. T., E. G. Keshock, and R. N. McGill, "Development of a Generalized Correlation for Phase Velocity Measurements Obtained from Impedance Probe Pairs in Two-Phase Flow Systems," ASME-JSME Thermal Engineering Joint Conference Proceedings, Honolulu. Hawaii, March 20-24. 1983. ASME-JSME, 1983.

Hunsaker, D. B., Jr., and G. H. Schenk, "The Determination of Thiols with Diphenylpicrylhydrazyl as a Spectrophotometric Reagent," Talanta 30, 475-80 (July 1983).

Huntley, W. R., "Performance Test Results of an Absorption Hcat Pump That Uses LowTemperature $\left[60^{\circ} \mathrm{C}\left(140^{\circ} \mathrm{F}\right)\right]$ Industrial Waste Heat," pp. 1921-26 in Proceedings of the 18th IECEC. American Institute of Chemical Engineers, New York, 1983.

Intemann, P. R., and P. D. Fairchild, "The Applicability of Earth-Coupled Heat Pumps and Factors Affecting Their Performance," Final Proceedings, Fifth Miami International Conference on Alternative Energy Sources, Elsevier Science Publications, Amsterdam, in press.

Jackson, W. L., and F. C. Chen, A Simulation Model for Shipboard Heat Pumps: User's Manual for Version II. N61533-81-GO-00019/1, David W. Taylor Naval Ship R\&D Center, U.S. Department of the Navy, August 1983.

Jewell, W. T., "A Reviewer's Guidelines for Writing Proposals," IEEE Transactions on Professional Communications, June 1983.

Jewell, W. T., Advanced Power Conversion Concepts for HVDC Transmission Systems, ORNL 5898, Oak Ridge National Laboratory, January 1983.

Jewell, W. T., "Avoiding Some Common Mistakes in Writing Proposals," Proceedings of the IEEE Professional Communication Society Conference, Boston, Mass., Oct. 13-15, 1982, Institute of Electrical ar.d Electronic Engineers, New York, 1982.

Jewell, W. T., R. C. Dugan, and D. J. Roesler, "Harmonics and Reactive Power from LineCommutated Inverters in Proposed Photovoltaic Subdivision," IEEE Trans. Power Appar. Syst. PA.j-102, $3205 \ldots 11$ (September 1983). 
Jones, D. W., "A Land Use Model with a Constant-Utility, Spatially Variant Wage," Gengraphical Analysis, accepted for publication.

Jones, D. W., "A Nooclassical Land Use Model with Production, Consumption, and Exchange," Geogr. Analy. 15(2), 128-41 (April 1983).

Jones, D. W., "Farm Location and Off-Farm Employment: An Analysis of Spatial Risk Strategies," Transactions, Institute of British Geographers, accepted for publication.

Jones, D. W., "Location, Agricultural Risk, and Farm Income Diversification," Geogr. Amaly. 15(3), 231-46 (July 1983).

Jones, D. W., "Mechanisms for Geographical Transmission of Economic Fluctuations," Annals of the Association of American Geographers 73(1), 35-50 (March 1983).

Jones, D. W., "Regional Economic Adjustment Mechanisms: Tineory and Evidence from United States Cities, 1918-1931," Journal of Regional Science, accepted for publication.

Jones, D. W., and C. Kaul, "Location and Agricultural Risk in India," Urbanization, Resources and Environment in Development Countries, eds. M. Chatterjec, P. Nijkamp, T. R. Lakshmanan, and C. R. Pathak, Gower, London, 1983.

Jones, D. W., and C. R. Morrow-Jones, "Consequences of Income Redistribution Through Local Taxation," Modeling Simulation 14, 927-34 (March 1983).

Jones, D. W., and C. R. Mortow-Jones, "Income Redistribution and the Effects of Five Local Taxes in a Small Region," Papers, Regional Science Association (North American Meetings). accepted for publication.

Jones, D. W., and C. R. Morrow-Jones, "Local Taxation and the Consequences of Revenue Distribution Patterns," Regional Science and Urban Economic, accepted for publication.

Kaplan, S. I., Evaluation of MCCC and Northwest Mississippi Junior College Solar Power Systems, ORNL/TM-8396, Oak Ridge National Laboratory, December 1982.

Karnitz, M. A., and J. O. Kolb, District Heating/Cogeneration Application Studies for the Minneapolis-St. Paul Area: Summary of Twin Cities Case Study and the St. Paul Project, ORNL/TM-6830/PI, Oak Ridge National Laboratory, February 1983.

Karnitz, M. A., and R. E. Gant, "Potential Opportunities for Revitalizing a Steam District Heating System: A Case Study of Rochester, New York," Dist. Heat. 67, 24-30 (1982).

Karnitz, M. A., T. K. Stovall, and H. A. McLain, Residential Conservation Servir. Model Audit Manual, ORNL/CON-103, Oak Ridge National Laboratory, October 1983.

Kelly, M. J., R. M. Rush, H. F. Bauman, and W. R. Ott, Analysis of Availability of Previously Identified Sites Und:r Alternative Demographic Criteria, ORNL-5936, Oak Ridge National Laboratory, July 1983.

Ketelle, R. n., Report of Preliminary Site Characterization of the West Chestnut Ridge Site, ORNL/NFW-82/21, Oak Ridge National Laboratory, October 1982.

Kclb, J. O., and K. Teichman, District Heating/Cogeneration Application Studies for the Minneapolis-St. Paul Area: Building Conversion Costs and Economics for the St. Paul Hot Water District Heating Market, ORNL/TM-6830/P7, Oak Ridge National Laboratory, February 1983.

Krummel, J. R., C. C. Gilmore, and R. V. O'Neill, Siting Field Research in the Western Kentucky Energy Development Region: An Expluration of a Regional Approach, ORNL/TM-8581, Oak Ridge National Laboratory, March 1983. 
Kulp, G., H. J. Tsao, and R. E. Webber, An Evaluation of Ridesharing Programs in Michigan, ORNL/CON-99, Oak Riáge National Laboratory, 1982.

Kulp, G., and M. C. Holcumb, Transportation Energy Data Book, 6th ed., ORNL-5883, Oak Ridge National Laboratory, October 1982.

Large, D. E., L. J. Mezga, L. E. Stratton, and R. R. Rose, Proceedings of the Fourth Annual Participants' Information Mecting, ORNL/NFW-82/18, Oak Ridge National Laboratory, October 1982.

Lee, D. W., R. H. Ketelle, F. G. Pin, and G. S. Hill, “Environmental Pathways Analysis for Evaluation of a Low-Level Waste Disposal Site," Prxceedings, IAEA Internationu! Conference on Radioactive Waste Management, Seattle, Washington, May I6-20, 1983, International Atomic Energy Agency, Vienna, in press.

Lee, D. W.. R. H. Ketelle, and L. H. Stinton, Use of DOE Site Selection Criteria for Screening LLW Disposal Sites on the Oak Ridge Reservation, ORNL/TM-3717, Oak Ridge National Laboratory, September 1983.

Lee, R., "Exploration Decisionmaking in a Simulation Model of Long-Range Mineral Supply," Modeling Simulation 14, 635-41 (March 1983).

Lee, R., and C. R. Thomas, Recommendations for the Analysis of Nonfuel Mineral Supply, Final Report to the U.S. Bureau of Mines, U.S. Bureau of Mines, March 1983.

Levins, W. P., "Energy Interactions Between Building Equipment Systems," pp. 309-28 in Praceedings of 1983 International Appliance Technical Conference, May 17-18, 1983, Purdue University.

Levins, W. P., "Measured Effect of Forced Ventilation on House Infiltration Rate," pp. 407-21 in Proceedings of the ASHRAE/DOE Conference-Thermal Performance of the Exierior Envelopes of Buildings II. ASHRAE, Inc., New York, 1983.

Liepins, G. E., "Automatic Data Editing: A Brief Introduction," pp. 339-43 in Proceedings of the Eighteenth Annual Meeting of the Institute of Management Sciences, ed. Carl Gooding, Institute of Management Sciences, October 1982:

Liepins, G. E., "Can Automatic Data Editing Be Justified: One Person's Opinion," in Statistical Methods and Improvement in Data Quality, Academic Press, New York, 1983.

Liepins, G. E., "Fourier-Motzkin Elimination as a Technique for Error Localization," pr.. i iv-77 in Proceedings of the Nineteenth Annual Meeting of the Institute of Management Sciences, ed. John Eatman, Iristitute of Management Sciences, September 1983.

Liepins, G. E., Fourier-Motzkin Elimination for Mixed Systems, ORINL/TM-8659, Oak Ridge National Laboratory, August 1983.

McCold, L. N., N. E. Collins, and P. Zuschneid, Thermal Efficiency Standards and Codes-Volume I: State-of-the-Art Literature Review and Analysis of Secondary Data. ORNL/CON-101/V1, Oak Ridge National Laboratory, June 1983.

McConnell, B. W., T. W. Reddoch, S. L. Purucker, and L. D. Monteen, “Distribution Energy Control Center Experiment,". IEEE Trans. Power Appar. Syst. PAS-102, 1582-89 (1983).

McLain, H. A., and M. Olszewski, Using a Whole-House Fan to Decrease Air-Conditioning Energy Use-Estimate of Energy Savings and Economic Viability for Residential Applications, ORNL/CON-115, Oak Ridge National Laboratory, September 1983.

McLain, H. A., M. J. Brinker, and D. W. Gatton, "Potential Benefits of a Resource Recovery Facility in Detroit: Michigan," Dist. Heat. 69(1), 8-25 (1983). 
McLean, R. B., "The Gastropod Sheil: A Dynamic Resource That Helps Shape Benthic Conmmunity Structure," J. Exp. Mar. Biol. Ecol. 69, 151-74 (1983).

Mei, V. C., "Short-Tube Subcritical Flow," pp. 85-87 in Cavitation and Multiphase Flow Forum-1983, FED-Vol. Il, American Society of Mechanical Engineers, New York, 1983.

Mei, V. C., and Z. Lavan, "Performance of Cross-Cooled Desiccant Dehumidifiers," J. Sol. Energy Eng. 105, 300-304 (August 1983).

Menendez, L., Residential Energy Conservation Programs in Minnesota: The Northern States Power Experience, ORNL/CON-127, Oak Riơge National Labnratory, August 1983.

Menendez, L., The Residential Conservation Service in Connecticut: A Profile of CONN SAVE. ORNL/CON-126, Oak Ridge National Laboratory, June 1983.

Meyers, C. R., Postmining Land Use: A Bibliography of Existing Experience and Potential Alternative Uses for Reclaiming Surface Coal Mining Operations, OSM/TR-4-82, Office of Surface Mining, ORNL/TM-8016, Oak Ridge National Laboratory, November 1982.

Mezga, L. J., "Objectives of the Fourth Annual DOE LLWMP Participants Information Meeting," pp. 51-55 in Proceedings of the Fourth Annual Participants Information Meeting. ORNL/NFW-82/18, Oak Ridge National Laboratory, October 1982.

Mezga, L. J., G. B. Levin, and A. Goldberg, DOE Low-Level Waste Management Program Position Paper: Recommendations Concerning the Disposal of Low-Level Wastes by Methods Providing Greater Confinement Than Near-Surface Disposal, ORNL/NFW-83/01, Oak Ridge National Laboratory, January 1983.

Miller, W. A., Laboratory Evaluation of the Heating Capacity and Efficiency of a HighEfficiency, Air-10-Air Heat Pump with Emphasis on Frosting-Defrosting Operations, ORNL/CON-69, Oak Ridge National Laboratory, December 1982.

Murphy, R. W., Field Tes. of a Vertical-Fluted Tube Condenser in the Prototype Power Plant at the Raft River Geothermal Test Site, ORNL-5940, Oak Ridge National Laboratory, April 1983.

Nephew, E. A., and L. A. Abbatiello, Performance and Economics of Eight Alternative Systems for Residential Heating, Cooling, and Water Heating in 115 U.S. Cities, ORNL/CON-89, Oak Ridge National Laboratory, November 1982.

Nyman, H. O., J. O. Kolb, and M. Krawtbauer, District Heating/Cogeneration Applications Studies for the Minneapolis-St. Paul Area: Market Assessment and Economic Analysis of the St. Paul District Heating System. ORNL/TM-6830/P10, Vol. 1, Oak Ridge National Laboratory, Februaiy 1983.

Oakes, E. H., and A. H. Voelker, Wilderness Designation of BLM Lands and Impacts to the Availability of Energy Resources, ORNL/TM-8310, Oak Ridge National Laboratory, February 1983.

Peelle, E., "Socioeconomic Impact Assessment and Nuclear Power Plant Licensing: Greene County, New York," in Improving Impact Assessments: Increasing the Relevance and Utilization of Technical and Scientific Information, eds. S. Hart and G. Enk, Westview Press, Boulder, Colo., in press.

Peelle, E., R. B. Braid, D. W. Jones, and J. H. Reed, Reaching People with Energy Conservation Information: Four Statewide Residential Case Studies, ORNL-5984, Oak Ridge National Laboratory, September 1983. 
Perez-Blanco, H., and R. L. Linkous, -Overall Heat Transfer Coefficient for a Vertical-Tube Evaporator Cooler," pp. 511-16 in ASME-JSME Thermal Engineering Joint Conference Proceedings, rol. I, American Society of Mechanical Engineers, New York, 1983.

Perez-Blanco, H., and R. L. Linkous, Use of an Overall Heat Transfer Coefficient to Calculate Performance of an Evaporative Cooler, ORNL/TM-8250, Oak Ridge National Laboratory, February 1983.

Perry, A. M., K. Araj, W. Fulkerson, D. J. Rose, M. M. Miller, and R. M. Rotty, "Ei:-rgy Supply and Demand Implications of $\mathrm{CO}_{2}, "$ Energy 7, $991-1004$ (December 1982).

Perry, A. M., Atmospheric Retention of Anthropogenic $\mathrm{CO}_{2}$. Scenario Dependence of the Airborne Fraction, Electric Power Research Institute, Palo Alto, Calif., in press.

Peterson, B. E., "A Continuous Evacuation Model," Proceedings, Pittsburgh Modeling and Simulation Conference 14, 817-20 (1983).

Peterson, B. E., "Book Review of Contemporary Suburban America by Peter O. Muller," Growth Change 14(3), 53-54 (October 1982).

Peterson, B. E, "Selection of Case Study Cities and Expansion to National Totals," Transportation Research Record, accepted for publication.

Petrich, C. H., "Assessing Aesthetic Impacts in Siting a Nuclear Power Plant: The Case of Greene County, New Yurk," Environmental Impact Assess. Rev. 344), 311-?.1 (December 1982).

Petrich, C. H., W. E. Manrod, and W. D. Barton, “Gengraphy, Demography, Topography, and Soils," in Tepartment of Energy Oak Ridge Reservation Resource Management Plan, vol. I, coord. T. W. Oakes, H. M. Braunstein, J. T. Kitchings, W. W. Chance, and D. B. Slaughter, June 1983.

Pin, F. G., A. J. Witten, R. D. Sharp, and E. C. Long, A Numerical Study of Unsaturated Flows and Seepage of Contaminants from Subgrade Mill Tailings Disposal Areas Equipped with Bottom Clay Liners, ORNL/TM-8822, Oak Ridge National Laboratory, 1983.

Pin, F. G., and J. E. Molyneux, The Behavior of Moist Buoyant Turbulent Plumes from Isolated Sources of Moisture and Heat. ORNL/TM-8358, Oak Ridge National Laboratory, November 1982.

Pine, G. D., W. G. Sullivan, M. Eksel, and M. A. Karnitz, "Economic Tradeoffs Between Conservation Measures and District Heating in a Large U.S. City." pp. 71-79 in Proceedings of the Annual 1 idustrial Engineering Conference, New Orleans, Louisiana, May 26, 1982, IIE-P-225, Indust ial Engineering and Management Press, Norcross, Ga., 1982.

Rayner, S. F., “Alain "ouraine et al., Anti-Nuclear Protest: The Opposition to Nuclear Energy ir France" Sociologic al Review, accepted for publication.

Rayner, S. F., "Mary Jouglas: In the Active Voice" Sociol. Rev. 31(3), 539-43 (August 1983).

Reddoch, T. W.. and D. H. Curtice, "An Assessment of Load Frequency Control Impacts Caused by Smp": Wind Turbines," IEEE Trans. Power Appar. Syst. PAS-102, 162-70 (January i;03).

Reddoch, T. W., and D. T. Rizy, "Electric Utility Intertie Issues for Small, Dispersed Power Sources," pip. 4-71-4-78 in EPRI Conference Proceedings: Solar and Wind Power-1982 Status and Outlook, EPRI AP-2884-SR, Electric Power Research Institute, Palo Alto, Calif,, 1983.

Reed, A. W., D. B. Hunsaker, Jr., R. D. Roop, and J. W. Webb, Evaluation of NEPA-Based Environmental Cummitments at Four Geopressure Design Wells, ORNL/TM-8657, Oak Ridge National Laboratory, September 1983. 
Reed, A. W., S. G. DeCicon, N. E. Hinkle, D. B. Hunsaker, Jr., F. C. Kornegay, R. C. Martin, R. D. Roop, and L. L. Sigal, Coal Use Handbook for Conversion of Heating and PowerGenerating Plants (20-100 Million Bru/h Capacity). ORNL/TM-8658, Oak Ridge National Laboratory, September 1983.

Rizy, C. G., and R. J. Maddigan, "Forecasting the Cooperatives' Electricity Costs," American Statistical Assaciation 1982 Proceedings of the Business and Economics Statistics Section, Washington, D.C., 1983.

Rizy, C. G., "An Integrated System for Forecasting Electric Energy and Load for States and Utility Service Areas," Appendix in Conducting Need-for-Power Review for Nuclear Power Plants, NUREG-0942, U.S. Nuclear Regulatory Commission, December 1982.

Rizy, C. G., "The ORNL Integrated Forecasting System," Proceedings of the Maryland Conference on Electric Utility Load Forecasting. Maryland Power Plant Siting Program, Annapolis, June 1983.

Rizy, C. G., R. B. Shelton, and R. J. Maddigan, Proceedings of the Workshop on Electricity Demand Forecasting by State Agencies, ORNL/TM-8692, Oak Ridge National Laboratory, July 1983.

Rizy, C. G., R. J. Maddigan, and W. S. Chern, "Rural Residential Demand for Electricity," Land Econ 59(2), 150-62 (May 1983).

Rizy, C. G., R. J. Maddigan, and W. S. Chern, "The Irrigation Demand for Electricity," Am. J. Agric. Econ. 64(4), 673-80 (November 1982).

Rizy, C. G., and R. J. Maddigan, "Modeling Demand and Supply Interactioris to Forecast Load Growth for Electricity Distribution Systems," Energy, accepted for publication.

Rizy, C. G., R. J. Maddigan, and W. S. Chern, "The Future of Rural Electrification in the United States," Energy Policy, accepted for publication (June 1984).

Rizy, D. T., R. C. Dugan, and S. A. Thomas, "Integrating Dispersed Storage and Generation (DSG) with an Automated Distribution System," in IEEE Power Engineering Society Summer Meeting. 83 SM 440-5, July 1983.

Rizy, D. T., and R. C. Dugan, "Electric Distribution Protection Problems Associated with the Interconnection of Small, Dispersed Generation Devices," in IEEE Power Engineering Society Summer Meeting. 83 SM 439-7, July 1983.

Rizy, D. T., and W. T. Jewell, "Interconnection Problems Associated with Dispersed Electric Generators and Inverter Devices," p. 153 in Proceedings of the Fourth Annual Modeling and Simulation Conference, vol. 14, April 1983.

Roberts, G. F., "Analysis of the Market Potentials of Future Automotive Technologies," IEEE Proc. Int. Conf. Cybern. Soc., 120-24 (October 1982).

Roberts, G. F., and D. L. Greene, "A Method for Assessing the Market Potential of New EnergySaving Technologies," IEEE Trans. Syst. Man, Cybern. SMC-13(1) 30-37 (January/February 1983).

Robertson, R. C., "Waste Heat Disposal from U.S. Geothermal Power Plants-An Update," Geotherm. Mag. I2(!), 17-28 (1983).

Roop, R. D., W. P. Staijo, D. B. Hunsaker, Jr., R. H. Ketelle, D. W. Lee, F. G. Pin, and A. J. Witten, A Review of Corrective Measures 10 Stabilize Subsidence in Shallow-Land Burial Trenches, ORNL/TM-8715, Oak Ridge National Laboratory, May 1983.

Rorke, M. L., L. M. Bronfman, and E. J. Soderstrom, Evaluation of the Energy-Related Inventions Program, Volume l: Analysis of Case Studies of Supported Projects, ORNL/CON-92/VI, Oak Ridge National Laboratory, February 1983. 
Samuels, G., Options for Electricity Use and Management During a Petroleum Shortage, ORNL5918, Oak Ridge National Laboratory. January 1983.

Schuler, R. E., and B. F. Hobbs, "Spatial Price Duopoly Under Uniform Delivered Pricing," J. Ind. Econ. 31(1/2), 175-87 (December 1982).

Schweitzer, M., “Energy Planning to Meet Your Communities' Needs," Sol. Val. Mag. 1(3), 3-4, (Summer 1982).*

Schweitzer, M., "The Process of Community Energy Planning," An Introduction to Energy Planning at the Community Level, Energy Planning Division of the American Planning Association, Washington, D.C., April 1983.

Schweitzer, M., S. A. Carnes, E. J. Soderstrom, and R. B. Braid, "Synthetic Fuel Development: Potential Socioeconomic Impacts Associated with Single and Multiple Projects," Energy Policy 11, 333-46 (1983).

Schweitzer, M., and S. A. Carnes, Local Government Programs to Save Energy: Case Studies of Four Selected Communities, ORNL-5982, Oak Ridge National Laboratory, September 1983.

Seddon, J., and C. H. Petrich, Case Studies: Developing Land Uses in Surface Mine Reclamation, OSM/TR-1-83, Office of Surface Mining, ORNL/TM-8017, Oak Ridge National Laboratory, June 1983.

Seddon, J., and C. H. Petrich, Management of Public Impacts in Surface Mining. ORNL/TM-1672, Oak Ridge National Laboratory, March 1983.

Shapira, H. B., G. A. Cristy, S. E. Brite, and M. B. Yost, Cost and Energy Comparison Study of Above- and Belowground Dwellings, ORNL/CON-91, Oak Ridge Nationa! Laboratory, August 1983.

Shapira, H. B., G. A. Cristy, S. E. Brite, and M. B. Yost, “Cost and Energy Comparison Study of Above- and Belowground Dwellings," Underground Space J. 7(6), 362-71 (June 1983).

Shelton, R. B., "Changing Energy Research Priorities," in Proceedings of the 1982 Association for University Business and Economic Research, Frontiers of Business and Economic Research Management, University of Illinois, Champaign-Urbana, 1983.

Skolits, D. J., and R. Lee, Sources of Coal Reserve Data, ORNL/TM-8481, Oak Ridge National Laboratory, November 1982.

Soderstrom, E. J., "Difĩiculties in Measuring Energy Savings," Energy Policy, accepted for publication.

Soderstrom, E. J., "Invention and Innovation by Individuals and Small Businesses: The Evaluation of the Energy-Related Inventions Program," in The Restructuring Economy, ed. A. Fiskesen, Bentley College, Waltham, Mass., 1982.

Soderstrom, E. J., E. A. Hirst, D. L. Greene, and J. L. Trimble, "Have Department of Energy Conservation Programs Saved Energy?" Evaluation Review, in press.

Soderstrom, E. J., L. M. Bronfman, and M. L. Rorke, The Energy-Related Inventions Program: An Overview and Assessment, ORNL/CON-92/V3, Oak Ridge National Laboratory, September 1983.

Sorensen, J. H., "Emergency Planning for Rare Events: Some Behavorial Science Lessons for Volcano Hazard Management," pp. 153-68 in Status of Volcanic Prediction and Emergency Response Capahilities in Volcanic Hazard Zones of California, eds. R. Martin and J. Davis, California Division of Mines and Geology, Special Publication No. 63, Sacramento, Calif., 1982.

•Omitted from FY 1982 report. 
Sorensen, J. H., "Evaluation of the Effectiveness of Warning Systems for Nuclear Power Plant Emergencies: Criteria and Application," in Nuclear Power: Assessing and Managing Hazardous Technology, eds. M. J. Pasqualetti and K. D. Pijawka, Westview Press, Boulder, Cojo., accepted for publication.

Sorensen, J. H., "Knowing How to Behave Under the Threat of Disaster: Can It Be Explained?" Environ Behavior 15(4), 438-57 (July 1983).

Sorensen, J. H., “Managing Energy Emergencies," Geoforum 14(1), 15-24 (1983).

Sorensen, J. H., D. Mileti, and J. Hutton, "Institutional Management of Risk Information Following Earhquake Predictions," A Collection of Papers on World Seismic Sociology, eds. Song Shouquan and Li Huaying, Institute of Geophysics, State Seismological Bureau, Beijing, China, November 1982.

Sorensen, J. H., E. J. Soderstrom, R. Bolin, E. D. Copenhaver, and S. A. Carnes, Restarting TMI Unit One: Social and Psychological Impacts, ORNL-5891, Oak Ridge National Laboratory, December 1983.

Sorensen, J. H., E. J. Soderstrom, and S. A. Carnes, "Sweet for the Sour: Incentives in Environmental Mediation," Environmental Management, accepted for publication.

Sorensen, J. H., Evaluation of the Emergency Warning System at the Fort St. Vrain Nuclear Power Plant, ORNL/TM-8171, Oak Ridge National Laboratory, November 1982.

Staub, W. P., Seismic Refraction Survey of the West Chestnut Ridge Site, ORNL/NFW-82/26, Oak Ridge National Laboratory, April 1983.

Staub, W. P., P. R. Intemann, J. B. Cannon, L. E. Stratton, C. F. Nern, and K. L. Falconer, A Process for Locating Shallow Land Burial Sites for Low-Level Radioactive Waste, DOE/LLW-16T, National Low-Level Radioactive Waste Management Program, U.S. Department of Energy, March 1983.

Stovall, J. P., W. A. Johnson, C. N. Whitmire, L. Mills, J-C. Rodrigue, F. S. Prabhakara, J. F. Torri, T. Niessink, and J. J. Gates, "System Restoration-Deploying the Plan," IEEE Trans. Power Appar. Syst. PAS-101, 4263-7! (November 1982).

Tepel, R. C., and D. L. Kaserman, "The Impact of Improved Mileage on Gasoline Consumption," Economic Inquiry, accepted for publication.

Thoma, R. E., "Molten Salt 'Technology," Ceram. Abstr. 62(5-6), 177-236 (May-June 1983).

Trumble, D. A., "Pricing Cogenerated Electricity," Int. J. Energy Syst. 3(2), 71-75 (1983).

Tsao, H. J., and T. Wright, The EIA-782B Interim Survey Design, U.S. Department of Energy, Aug. 4, 1982."

Tsao, H. J., and T. Wright, Preliminary Survey .Jar of ihe EIA-782B Survey. U.S. Department of Energy, June 21, 1982.*

Turhollo", A. F., Jr., “Potential Impacts of Future Energy Price Impacts on U.S. Agricultural Production," CARD Report 116. Center for Agricultural and Rural Development, Iowa State University, Ames, April 1983.

Turhollow, A. F., Jr., “Regional Impacts of Herbaceous and Woody Biomass Production on U.S. Agriculture," Proceedings of Energy from Biomass and Wastes VII, Institute of Gas Technology, Chicago, 1983.

•Omitted from FY 1982 report. 
Turhollow, A. F., Jr., "Soil Loss Associated with Alcohol Production from Corn Grain and Corn Residue," CARD Report 115, Center for Agricultural and Rural Development, Iowa State University, Ames, January 1983.

Van Dyke, J. W., and K. R. Corum, "Stimulating Energy Conservation in Commercial Buildings," Energy Poiicy 11(1), 52-62 (March 1983).

Vineyard, E. A., "Redesign Improves Efficiency of Gas-Fired Water Heater," Energygram: Brief Descr. Energy Technol. 3, 170-71 (1982).

Vineyard, T. A., "Analysis of Conservation and Renewable Options for New Single-Family Residences," pp. 2050-58 in Proceedings, 18th Intersociety Energy Conversion Engineering Conference, vol. 5, American Institute of Chemical Enegineers, New York, August 1983.

Weinblatt, H., T. S. Reddy, and A. F. Turhollow, Jr., Energy and Precious Fuels Requirements of Fuel Alcohol Production, Vol. II-Appendices A and B: Ethanol from Grain, NASA CR168091, National Technical Information Service, Springfield, Va., December 1982.

Wilbanks, T. J., “Energy Self-Sufficiency as an Issue in Regional and National Development," in Energy and Regional Growth, ed. T. R. Lakshmanan, Gower, London, 1983.

Wilbanks, T. J., "Geography and Our Energy Heritage," Mater. Soc. 7, 437-52 (1983).

Wilbarks, T. J., "Scale and the Acceptability of Nuclear Energy," in Nuclear Power: Assessing and Managing Hazardous Technology, eds. M. J. Pasqualetti and K. D. Pijawka, Westview Press, Boulder, Colo., accepted for publication.

Wilbanks, T. J., and M. Libbee, "Program Evaluation as a Strategy for Program Enhancement," Prof. Geog. 34, 381-86 (1982).

Wilbanks, T. J., and R. Lee, "Policy Analysis in Theory and Practice," in Regiona' Consequences of Large-Scale Energy Projects, eds. T. R. Lakshmanan and B. Johansson, I Jorth-Holland, Arnsterdam, accepted for publication.

\subsection{ENVIRONMENTAL IMPACT STATEMENTS AND ASSESSMENTS}

U.S. Department of Energy, Draft Environmental Assessment, CU-l Venture. Geothermal Loan Guaranty, Full Field Development, South Brawley Unit \#I, Imperial County. California, September 1983. [A. W. Reed, D. B. Hunsaker, R. D. Roop, P. R. Intemann]

U.S. Department of Energy, Final Environmental Impact Statement Supplement, Commercial and Apartment Conservation Service Program, DOE/EIS-0050-FS, August 1983. [J. W. Boyle, C. S. Dudney, E. J. Soderstrom, J. B. Sorensen]

U.S. Department of Energy, Environmental Assessment, Now England Ethanol, Inc., Loan Guarantee Application, Androscoggin, Maine, DOE/EA-0166, July 1983. [J. W. Boyle, C. C. Gilmore, C. T. Hunsaker, J. F. McBrayer, F. E. Sharples]

U.S. Nuclear Regulatory Commission, Final Environmental Statement Related to the Teton Uranium ISL Project, August 1983. [R. B. McLean]

U.S. Nuclear Regulatory Commission, Environmental Impact Appraisal for Renewal of Special Nuclear Material License No. SNM-1168. Babcock \& Wilcox Company, Commercial Nuclear Fuel Plant, Lynchburg, Virginia, Docket No. 70-1201, NUREG-0987, May 1983. [N. E. Hinkle, M. J. Kelly]

U.S. Nuclear Regulatory Commission, Environmental Impact Appraisal Related to Special Nuclear Materials License No. SNM-696, Docket No. 70-734, GA Technologies. Inc. (GA), Fuel Fabrication Facility, June 1963. [M. J. Keily] 


\subsection{PRESENTATIONS BY ENERGY DIVISION STAFE}

Adler, M. V., and K. S. Gant, -Additional Federal and State Radiological Emergency Response Capabilities," presented at DOE Radiological Emergency Preparedness Workshop, Oak Ridge, Tenn., Oct. 13-14, 1983.

Barnes, P. R., -EMP and Its Effects on Electrical Generation Systems," presented at Institute for Energy Analysis, Oak Ridge, Tenn., May 12, 1983.

Barnes, P. R., "Electromagnetic Pulse (EMP) and Its Implications for Electric Power Systems," presented to North American Electric Reliability Council Board of Trustes, Montreal, July $13,1983$.

Barnes, P. R., "Electromagnetic Pulse and Electric Power Systeans," presented at North American Electric Reliability Council, San Diego, Mar. 2, 1983.

Barnes, R. W., and T. A. Vineyard, -Methodology for the Evaluation of Alternative Energy Conservation Options," presented at the Seventh Ansual Energy Management and Controls Society Conference, Salt Lake City, Utah, Nov. 17, 1982

Bjornstad, D. J., E L. Hillsman, and R. C. Tepel, -Regional Variations in Projected Rates of Biomass Fuel Use on Farms," presented at North American Mectings of the Regional Science Association, Pittsburgh, November 1982.

Bjornstad, D. J., E. L. Hillsman, and R. C. Tepel, "The Potential for On-Farm Biomass Fuel Use During an Energy Emergency," presented at Annual Meeting, Southern Regional Science Association, Charleston, S.C., Apr. 13-15, 1983.

Boercker, F. D., "Floor or Perimeter Insulation: Which Way to Go?" presented at WATTec, Knoxville, Tenn., Feb. 23-25, 1983.

Braid, R. B., "Potential Impacts of the Synthetic Fuel Industry of the Eastern Coal Region," presented at First International Conference on Social Impact Assessment, Richmond, British Columbia, Canada, Oct. 24-27, 1982.

Braid, R. B., S. A. Carnes, M. Schweitzer, and E J. Soderstrom, Inupontance of Cumulative Impacts in the Impact Assessment Process," presented at First International Conference on Social Impact Assessment, Richmond, British Columbia, Canada, Oct. 24-27, 1982.

Broders. M. A., "Commercial Building Audit Survey." presented at NIBS/DOE Seminar on Thermal Insulation for Industrial/Commercial Applications, Los Angele , Apr. 8, 1983.

Cannon, J. B., and C. E. Easterly, "A Perspective on Occupational Radiation Exposures at a Hypothetical Fusion Power Station," presented at American Nuclear Snciety Annud Meeting. Detroit, June 12-16, 1983.

Cantor, R. A., "Time Series Data from the EIA-254 Data Base," presented to U.S. Nuclear Regulatory Commission, Bethesda, Md., Sept. 9, 1983.

Chester, C. V., "Hazard Mitigation Potential of Earth-Sheltered Residences," presented to Federal Emergency Management Agency, Washington, D.C., Mar. 11, 1983.

Chester, C. V., "ORNL Activities in Shelter Development," presented to Engineering and Services Laboratories, Tyndall Air Force Base, Fla., June 9. 1983.

Chester, C. V., "Strategic Importance of Vegetable Oii," presentcu at ASAE Summer Meeting. Bozeman, Idaho, June 28, 1983.

Childs, K. W., G. E. Courville, and P. W. Childs, "An Investigation of Faciors Influencing Infrared Roof Moisture Surveys," presented at Thermosense VI Conference, Oak Brook, I..., Oct. 2-5, 1983. 
Christian, J. E., "Thermal Envelope Field Measurements in an Energy Efficient Office/Dormitory," presented at ASHRAE/DOE Conference on Thermal Performance of Building Envelopes, Las Vegas, Dec. 6-9, 1982.

Christian, J. E., "Thermal Mass Comprehersive Analysis Work Scope," presented at National Bu:eau of Standards, Gaithersburg, Md., May 26, 1983.

Christian, J. E. "Thermal Mass Comprehensive Analysis Rationale," presented to Owens-Corning Fiberglass, Granville, Ohio, Sept. 13, 1983.

Christian, J. E., and F. Arumi, "NBS Field Validation Update," presented to Owens-Corning Fiberglass, Granville, Ohio, Sept. 13, 1983.

Christian, J. E, and G. E. Courville, "DOE/ORNL Thermal Mass Program Plan," presented to Construction Technology Laboratories, Skokie, Ill., Feb. 22, 1983.

Cohn, S. M., "A Model of Performance for the Annual Cycle Energy System (ACES)," presented at Annual Meeting of the American Statistical Association, Toronto, Ontario, Canada, Aug. 15, 1983.

Collins, N. E, "Data Collection Tools," presented at Practice, Problem-Solving, and Skills Development for Energy Program Evaluation-A Workshop for States, Philadelphia, Sept. 18-21, 1983.

Collins, N. E, "Generalizing and Transferring Evaluation Results," presented at Practice, Problem-Solving, and Skills Development for Energy Program Evaluation-A Pilot Workshop for States, Salt Lake City, Mar. 1-3, 1983.

Collins, N. E., "Issues of Generalizing from and to Other Programs," presented at Practice, Problem-Solving, and Skills Development for Energy Program Evaluation-A Workshop for States, Philadelphia, Sept. 18-21, 1983.

Collins, N. E., "Selecting and Adapting Existing Data Collection Instruments to Specific Programs," presented at Practice, Problem-Solving, and Skills Development for Energy Program Evaluation-A Workshop for States, Providence, R.I., July 13-14, 1983.

Collins, N. E., "Selecting and Designing Evaluation Tools and Techniques," presented at Practice, Problem-Solving, and Skills Development for Energy Program Evaluation-A Pilot Workshop for States, Salt Lake City, Mar. 1-3, 1983.

Collins, N. E., "Standard Methodologies vs In-House Methodologies," presented at Practice, Problem-Solving, and Skills Development for Energy Program Evaluation-A Workshop for States, Philadelphia, Sept. 18-21, 1983.

Collins, N. E., "Threats to Validity," presented at Practice, Problem-Solving, and Skills Development for Energy Program Evaluation-A Workshop for States, Philadelphia, Sept. 18-21, 1983.

Courville, G. E., "Applications of Thermal Infrared Sensing to Buildings," presented at Techniques for Extraction of Information from Remotely Sensed Images, sponsored by the Society of Photographic Scientists and Engineers, Rochester, N.Y., Aug. 18, 1983.

Courville. G. E., "Professionalism in Commercial Infrared Sensing-an Update," presented at Thermosense V, Detroit, Oct. 25, 1982.

Creswick, F. A., "Heat Pump Research at ORNL," presented at Heat Pump Institute, University of Tennessee, Knoxville. Nov. 15-18, 1982.

Creswick, F. A., "Increasing Heat Pump Efficiency," presented at Mechanical Engineering Seminar, University of Tennessee, Knoxville, Nov. 23, 1982. 
Creswick, F. A., "Recent Developments in Residential Heat Pump Research," presented at Midwest Residential Energy Technology Worisshop, Columbus, Ohio, June 16-17, 1983.

Davis, R. M., and L. W. Rickert, "The Impact of Energy Exploration, Development, and Production on State Revenues," presented at Southern Regional Science Association Meetings, Charleston, S.C., Apr. 13-15, 1983.

Fairchild P. D., and C. D. West, "Heat-Activated Heat Pump Development and Potential Application of Stirling Engine Technology," presented at 20th Automotive Technology Development Contractor Coordination Meeting, Dearborn, Mich., Oct. 25-28, 1982.

Flanagan, D. M., “An Economic Analysis Code for Selecting Building Design Options," presented at 1983 ASHRAE Arnual Meeting, Washington, D.C., June 25-26, 1983.

Gant, K. S., "The Relationship of Power Reactor Siting and Protective Actions," presented to Health Physics Society, Bcltimore, June 19-23, 1983; and East Tennessee Chapter of Health Physics Society, Oak Ridge, Tenn., July 28, 1983.

Gant, K. S., and M. V. Adler, "Application of the Radiological Defense Capabilities to Peacetime Radiological Incidents," presented at Radiological Defense Officers Conference, Seattle, July 12-14, 1983.

Gant, K. S., and M. V. Adler, "The Application of the RADEF System to Peacetime Radiological Emergencies," presented at Radiological Defense Officers/Office of Emergency Services, RADEF Conference, Ontario, Calif., Sept. 13-24, 1983.

Greene, D. L., "A Comment on Streamlining the Collection and Processing of Traffic Count Statistics," presented at 62nd Annual Meeting of the Transportation Research Board, Washington, D.C., January 1983.

Greene, D. L., "Highway Fuel Use: Trends and Factors," presented at Petroleum Supply Information Symposium, Energy Information Administration, Arlington, Va., Aug. 24, 1983.

Greene, D. L., "Issues in Regional Motor Fuels Demand Forecasting and Inalysis," Texas Energy and Natural Resources Advisnry Council, Austin, Tex.; and Transportation Center, Texas A \&M University, College Station, Feb. 11, 1983.

Greene, D. L., P. S. Hu, and G. F. Roberts, "An Analysis and Temporal Variation in Vehicle Classification Count Statistics," presented at Annual Meeting of the Association of American Geographers, Denver, Apr. 24-27, 1983.

Grossman, G., and Y. W. Childs, "Computer Simulation of a Lithium Bromide-Water Absorption Heat Pump for Temperature Boosting," presented at ASHRAE Semiannual Meeting, Atlantic City, N.J., Jan. 23-26, 1983.

Haaland, C. M., "Facts About Nuclear Weapons Effects and Defenses Against Them," presented at Arizonans for National Security September Meeting, Tempe, Ariz., Sept. 21, 1983.

Hamblin, D. M., "Past, Present, and Future Roles of a National Laboratory in Capacity Planning," presented at Symposium on Computer Analysis of Electric Load Forecasting and Generation Capacity Expansion, Ohio State University, Columbus, Sept. 14, 1983.

Hillsman, E. L., "Locational Analysis of the Suitability of Places," presented at annual meeting of the Association of American Geographers, Denver, Apr. 24-27, 1983

Hirst, E., "Alternative Estimates of Program Energy Savings: The BPA Residential Weatherization Pilot Program," Electric Power Research Institute, Residential Conservation Strategy Evaluation Model Advisory Group Meeting, Portlend, Oreg., Apr. 22, 1983. 
Hirst, E, "Analysis of Energy Use at U.S. Institutional Buildings" and "Residential Energy Use and Retrofit Investments," presented at annual meeting of the International Association of Energy Economists, Denver, Nov. 18, 1982.

Hirst, E, "Effects of Improved Energy Efficiency on U.S. Energy Use-Past, Present, Future," presented at ORNL Summer Seminar Series, Oak Ridge National Laboratory, Oak Ridge, Tenn., June 21, 1983.

Hirst, E, "Evaluating State Energy Conservation Programs-Do They Work?" presented at workshop for states on Practice, Problem-Solving, and Skills Development for Energy Program Evaluation, sponsored by the U.S. Department of Energy in Philadelphia, Sept. 19, 1983.

Hirst, E., "Evaluating Utility Conservation Programs," presented at 1982 Conference of Southeastern Electric Exchange, St. Petersburg Beach, Fla., Nov. 4, 1982.

Hirst, E., "Evaluating Utility Conservation Programs," presented at seminar sponsored by the New York Public Service Commission on Utility Investment in Conservation, Rensselaerville, N.Y., Oct. 5-6, 1982.

Hirst, E., "Evaluating the Residential Conservation Service Program," presented at meeting sponsored by the National Governors' Association, Washington, D.C., Oct. 7, 1982.

Hirst, E., "Evaluation of the BPA Residential Weatherization Pilot Program," presented at Center for Energy and Environmental Studies, Princeton University, Mar. 22-23, 1983.

Hirst, E., "How U.S. Energy Use and Efficiency Have Changed Since 1973," presented at Southern Colleg: University Union, 1983 Oak Ridge Science Semester, Oak Ridge National Laboratory, Oak Ridge, Tenn., Feb. 3, 1983.

Hirst, E., "Measuring Effects of Utility Conservation Programs: inputs to Utility Decisionmaking," presented at EPRI conference on Utility Conservation Programs: Planning, Analysis, and Implementation, New Orleans, La., Segt. 13, 1983.

Hirst, E., "Measuring the Effects of Utility Conservation Programs," presented at Edison Electric Institute seminar on Conservation and Load Management: Opportunities for Diversification and Cust Saving, Orlando, Fla., Feb. 17-18, 1983.

Hirst, E., "Residential Energy Use and Retrofit Investments," presented at International Association of Energy Economists, 4th Annual Meeting, Denver, Nov. 18, 1982.

Huntley, W. R., "Performance Test Results of an Absorption Heat Pump That Uses LowTemperature $\left[60^{\circ} \mathrm{C}\left(140^{\circ} \mathrm{F}\right)\right]$ Industrial Waste Heat," presented at 18 th International Energy Conversion Engineering Conference, Orlando, Fla., Aug. 21-26, 1983.

Jewell, W. T., "Harmonics and Reactive Power," presented at IEEE Power Engineering Society 1983 Winter Meeting, New York, Jan. 29-Feb. 4, 1983.

Jewell, W. T., "Planning Regional Interchanges of Electric Energy to Reduce the Need for New Generating Capacity," presented at 15th Annual Meeting of the Mid-Continent Science Association, Oklahoma City, June 5-7, 1983.

Jewell, W. T., "Simulation of Solar Subdivision Addresses Utility Questions About Integration of Solar Photovoltaics," presented at SOUTHEASTCON'83, IEEE Region 3 Conference, Orlando, Fla., Apr. 11-14, 1983.

Jones, D. W., and C. R. Morrow-Jones, "Consequences of Income Redistribution Through Local Taxation," presented at Pittsburgh Modeling and Simulation Confe:ence, Pittsburgh, Apr. $21-22,1983$. 
Jones, D. W., and C. R. Morrow-Jones, "Income Redistribution and the Effects of Five Local Taxes in a Small Region," presented at Twenty-Ninth North American Regional Science Meeting, Pittsburgh, Nov. 14, 1982.

Jones, D. W., and C. R. Morrow-Jones, -Influences of Income Redistribution through Public Spending on the Incidence of Five Local Taxes," presented at Annual Meciing of the Association of American Geographers, Denver, Apr. 25, 1983.

Kaplan, S. I., "Technical Assistance to DOE Pbotovoltaic Grant Projects," presented at DOE Solar Phocovoltaic Technology Program Semiannual Review, Washington, D.C., Oct. 27, 1982

Kaplan, S. I., "Progress in Solar Applications," presented at Environmental Quality and Natural Resources Seminar, U.S. Office of Personnel Management Executive Seminar Center, Oak Ridge, Tenn., May 2, 1983.

Karnitz, M. A., "Pressure-Flow Modeling of Akron, Ohio, Steam District Heating Distribution Network," presented at International District Heating Association Meeting, Lancaster, Pa., June 19-23, 1983.

Kolb, J. O., "Utility Cogeneration Applications for District Heating," presented at WATTec, Knoxville, Tenn., Feb. 23-25, 1983.

Kornegay, F. C., -Meteorological Research at ORNL," presented at ORNL Colloquium, Oak Ridge, Tenn., Aug. 9, 1983.

Kornegay, F. C., "The Air Quality Impacts Associated with Replacing Indian Point Units 2 and 3 with Fossil-Fired Facilities," presented as Testimony, Indian Point Hearings, White Plains, N.Y., Apr. 22, 1983.

Lee, D. W., "Environmental Pathways Analysis for Evaluation of a Low-Level Waste Disposal Site," presented at IAEA international Conference on Radioactive Waste Management, Seattle, Wash., May 16-20, 1983.

Lee, R., "A Model for Materials Activity and Decision Simulation," presented at Annual Meeting, Association of American Geographers, Denver, Apr. 24-27, 1983.

Lee, R., "Exploration Decisionmaking in a Simulation Model of Long-Range Mineral Supply," presented at Pittsburgh Modeling and Simulation Conference, Pittsburgh, Apr. 20-21, 1983.

Levins, W. P., "Energy Interactions Between Building Equipment Systems," presented at International Technical Appliance Conference, West Lafayette, Ind., May 17-18, 1983.

Levins, W. P., - Measured Effect of Forced Ventilation on House Infiltration Rate," presented at ASHRAE/DOE Conference on Thermal Performance of Building Envelopes, Las Vegas, Dec. 5-9, 1982.

Liepins, G. E., “A Time Series Comparison and Analysis of Federally Collected Petroleum Data," presented at TIMS/ORSA Semiannual Meeting, Chicago, Apr. 24-27, 1983.

Liepins, G. E., “Automatic Data Editing: A Brief Introduction," presented at Southeastern TIMS Meeting, Myrtle Beach, S.C., Oct. 7-8, 1982.

Liepins, G. E., "Can Automatic Data Editing Be Justified," presented at Conference on the Impróvement of the Quality of Data Collected by Data Collection Systems, Oak Ridge, Tenn., Nov. 11-12, 1982.

Liepins, G. E., "Fourier-Motzkin Elimination as a Technique for Error Localization," presented at Nineteenth Annual Meeting of the Institute of Management Sciences, Myrtle Beach, S.C., Sept. 29-30, 1983. 
Loebl, A. S., "Numbers Can Be Data but They Aren't Always Information," presented at Annual Meeting of the Evaluation Research Society, Baltimore, Oct. 28, 1982.

McConnell, B. W., "Customer Response in Department of Energy Load Management Projects," presented at EPRI Load Management Seminar, San Antonio, Tex., Dec. 8-10, 1982.

McConnell, B. W., "Modeling the Effects of Corona on Electric Power Line Surges Induced by Electromagnetic Pulse," presented at 1983 Conference on Nuclear and Space Radiation Effects, Gatlinburg, Tenn., July 19-21, 1983.

McConnell, B. W., "Summary of the Athens Automation and Control Experiment's Attitude Surveys," presented at IEEE Power Engineering Society 1983 Winter Meeting, New York, Jan. 29-Feb. 4, 1983.

McGill, R. N., C. T. Hsu, and E. G. Keshock, "Development of a Generalized Correlation for Phase Velocity Measurements Obtained from Impedance Probe Pairs in Two-Phase Flow Systems," presented at ASME-JSME Joint Thermal Engineering Conference, Honolulu, Mar. 20-24, 1983.

McLean, R. B., S. M. Adams, and J. W. Minton, "Effects of Fluctuating Forage on Three Predators in a Southeastern Reservoir," presented at American Fisheries Society Meeting, Milwaukee, Aug. 16-19, 1983.

Mei, V. C., "Laboratory Tests of a Residential Low-Temperature Water Source Heat Pump," presented at 1983 ASHRAE Annual Meeting, Washington, D.C., June 26-30, 1983.

Mei, V. C., "Short Tube Subcritical Flow," presented at Cavitation and Multiphase Flow Conference, ASME Fluid Engineering Division, Houston, June 20-23, 1983.

Mei, V. C., and S. K. Fischer, "Vertical Concentric Tube Ground-Coupled Heat Exchangers," presented at 1983 ASHRAE Annual Meeting, Washington, D.C., June 26-30, 1983.

Mezga, L. J., "Objectives of the Fourth Annual DOE LLWMP Participants Information Meeting," presented at Fourth Annual DOE LLWMP Participants Information Meeting, Denver, Aug. 31 and Sept. 1-2, 1982.

Mezga, L. J., "The Role of Trench Caps in the Shallow Land Burial of Low-Level Waste," presented as an ORNL Laboratory-Wide Colloquium, Oak Ridge, Tenn., May 10, 1983.

Minturn, R. E., "Some Thoughts on Diurnal Storage Based on ACES Experience," presented at EPRI Cool Storage Workshop, Palo Alto, Calif., Jan. 19--20, 1983.

Peelle, E., "Technical Decision-Making and Its Impact," presented at Science for Humanity Series, Oak Ridge Childrens Museum, Oak Ridge, Tenn., Nov. 4, 1982.

Perez-Blanco, H., "Technologies for Waste Heat Recovery," presented at National Heat Transfer Conference, Seattle, Wash., July 24-25, 1983.

Perez-Blanco, H., and W. A. Bird, "Study of Heat and Mass Transfer in a Vertical-Tube Evaporative Cooler," presented at ASME 1982 Winter Annual Meeting, Phoenix, Ariz, November 1982.

Perez-Blanco, H., and R. L. Linkous, "Overall Heat Trensfer Coefficient for a Vertical-Tube Evaporator Cooler," presented at ASME-JSME Thermal Engineering Joint Conference, Honolulu, Mar. 20-24, 1983.

Perry, A. M., "Atmospheric Retention of $\mathrm{CO}_{2}$ " presented at seminar at the Electric Power Research Institute, Palo Alto, Calif,, Dec. 21, 1982. 
Perry, A. M., "The $\mathrm{CO}_{2}$ Issue," presented at seminar at the Ele: itc Power Research Institute, Palo Alto, Calif., Dec. 21, 1982.

Perry, A. M., "The $\mathrm{CO}_{2}$ Issue: Key Questions and Related Research," presented to Divisional Committee, Energy Analysis and Environment Division, Electric Power Research Institute, Palo Alto, Calif., Feb. 8, 1983.

Peterson, B. E. “A Continuous Evacuation Model," presented at Pittsburgh Simulation and Modeling Conference, Pittsburgh, Apr. 21-22, 1983.

Petrich, C. H., and J. Greenwood, "Energy Conservation in Site Planning," presented at Site Planning and Facilities Utilization Workshop, U.S. Department of Energy 1982, Oak Ridge, Tenn., Nov. 9-11, 1982.

Purucker, S. L., “Athens Distribution Energy Control Center Project," presented at WATTœ, Knoxville, Tenn., Feb. 25, 1983.

Rayner, S. F., "The Perception of Occupational Hazards Through Ionizing Radiation in American Medicine," presented at International Institute of Applied Systems Analysis, Laxonburg. Austria, Mar. 16, 1983.

Reddoch, T. W., "Protection and Safety Needs for Small Power Sources Intertied to Electric Utility Systems," presented at Seminar on Utility Issues and Dispersed Photovoltaic Systems, Atlanta, May 3-4, 1983.

Reed, J. H., "Computers and Software," presented at Practice, Problem-Solving, and Skills Development for Energy Program Evaluation-A Pilot Workshop for States, Sal: Lake City, Mar. 1-3, 1983.

Reed, J. H., "Evaluation and the Organizational Environment," presented at Practice, ProblemSolving, and Skills Development for Energy Program Evaluation--A Workshop for States, Philadelphia, Sept. 18-21, 1983.

Reed, J. H., "Issues of Internal Validity and Bieses Which Cannot Be Eliminated Via Design," presented at Practice, Problem-Solving, and Skills Development for Energy Program Evaluation-A Workshop fo: States, Philadelphia, Sept. 18-21, 1983.

Reed, J. H., "Socio-Economic Aspects of the Athens Automated Control Experiment," presented at Contractors' Review Meeting for the Athens Automation and Control Experiment, Dallas, June 10, 1983.

Reed, J. H., and N. E. Collins, "Using Needs Assessment Results to Select Target Audiences," presented at Practice, Problem-Solving, and Skills Development for Energy Program Evaluation-A Pilot Workshop for States, Salt Lake City, Mar. 1-3, 1983.

Reed, J. H., and R. Broncato, "Economic and Employment Impacts," presented at Practice, Problem-Solving, and Skills Development for Energy Program Evaluation-A Workshop for States, Philadelphia, Sept. 18-21, 1983.

Reed, J. H., and R. Broncato, "Secondary Impacts," presented at Practice, Problem-Solving, and Skills Development for Energy Program Evaluation-A Workshop for States, Philadelphia, Sept. 18-21, 1983.

Rizy, C. G., "The ORNL Integrated Forecasting System," presented at Maryland Conference on Electric Utility Load Forecasting, Annapolis, Md., June 1983.

Rizy, D. T., "Electric Distribution Protection Problems Associated with the Incerconnection of Small, Dispersed Electric Generation Devices," presented at IEEE Power Engineering Society 1983 Summer Meeting, Los Angeles, July 18, 1983. 
Rizy, D. T., "Integrating Dispersed Storage and Generation with an Automated Distribution System," presinted at IEEE Power Engineering Society 1983 Summer Meeting, Los Angeles, July 18, 1983.

Rizy, D. T., "Interconnection Problems Associated with Small, Dispersed Electric Generators and Inverter Devices," presented at Fourteenth Annual Pittsburgh Modeling and Simulation Conference, Pittsburgh, Apr. 22, 1983.

Roberts, G. F., "Analysis of the Market Potentials of Future Automotive Technologies," presented at 1982 IEEE international Conference on Cybernetics and Society, Seattle, Oct. 28-30, 1982.

Samuels, G., "Liberian Biomass Resources and Technologies for Their Use," presented to Liberian National Energy Committee, Monrovia, Liberia, Nov. 12, 1982.

Sisapira, H. B., "Earth-Sheltered Housing, Passive Star Design Techniques and Research Utilization Activities at ORNL for DOE/BERD," presented to Technion r.partment of Civil Engineering, June 17, 1983; and Department of Architecture and Urban Planning, Technion Institute of Technology, Haifa, Israel, June 20, 1983.

Shapira, H. B., "Earth-Sheltered Structures-Energy Conservation, Hazard Mitigation and Optional Ground Utilization in Design and Construction," presented to Department of Physics and Applied Mathematics, Nahal Soreq Research, Israel, June 7, 1983.

Shapira, H. B., "Passive and Hybiid Solar, Innovative Structure and BTESIM Programs at ORNL," presented at University Sdeh Boker Campus, Beer Sheva, Israel, July 13, 1983.

Shapira, H. B., "Reducing the Cost of Shelters and Conservation in Design," presented at UCLA School of Architecture, University of California, Los Angeles, May 28, 1983.

Shelton, R. B., “Changing Energy Research Priorities," Keynote Address at Annual Conference of the Association for University Business and Economic Research (AUBER), Knoxville, Tenn., Oct. 25-27, 1982.

Soderstrom, E. J., "Designing Measurable Goals ard Objectives for Program Evaluation," presented at Practice, Problem-Solving, and Skills Development for Energy Program Evaluation-A Pilot Workshop for States, Salt Lake City, Mar. 1-3, 1983.

Soderstrom, E. J., “Evaluation Methods for Energy Conservation Program Evaluation," presented at Practice, Problem-Solving, and Skills Development for Energy Prugram Evaluation-A Workshop for States, Providence, R.I., July 13-14, 1983.

Sorensen, J. H., "Perceived Risks of Restarting Three Mile Island Unit One," presented at Annual Meeting, Association of American Geographers, Denver, Apr. 24-27, 1983.

Stovall, J. P., “Bibliography on Distribution Automation, 1969-1982," presented at IEEE Power Engineering Society 1983 Summer Meeting, Los Angeles, July 17-22, 1983.

Tsao, H. J., "A Frame on Frames: An Annotated Bibliography," presented at Conference on the Improvement of the Quality of Data Collected by Data Collection Systems, Oak Ridge, Tenn., Nov. 11-12, 1982.

Turhollow, A. F., Jr., "Application of Linear Programing to A E ciulture," presented at roundtable discussion on applications of linear programming, University of Tennessee, Knoxville, Apr. 5 , 1983.

Vineyard, T. A., "Analysis of Conservation and Renewable Options for New Single-Family Residences," presented at 18th Intersociety Energy Conversion Engineering Conference, Orlando, Fla., Aug. $21-26,1983$.

Wilbanks, T. J., "Economic Geography, Relevance, and Social Change," presented to Southeast Division, Association of American Geographers, Memphis, November 1982. 
Wilbanks, T. J., "Geography and Our Energy Heritage," presented at Conferesce on Energy in American History, Virginia Tech Center for the Study of Science in Society, October 1982.

Wilbanks, T. J., "Institutional Choices and Linkages in the New R\&D Partnership," presented at Symposium on National Science and Technology Policy, Americar Society for Public Administration, New York, April 1983.

Wilbanks, T. J., "Policy Analysis in Theory and Practice," presented at International Workshop on Regional Consequences of Large-Scale Energy Projects, IIASA, Laxenburg, Austria, February 1983.

Wilbanks, T. J., "Prospects for Local Energy Action," presented at Symposium on Social and Behavioral Aspects of Energy Consumption and Production, imerican Association for the Advancement of Science, Detroit, May 1983.

Wilbanks, T. J., "Scale and Energy Technology Choice," presented at Seminar Series on Technology Choice, Boston University, Boston, February 1983.

Wilbanks, T. J., "Social, Economic, and Institutional Issues in Radiation Protection," presented at WATTec, Knoxville, Tenn., February 1983.

Wilbanks, T. J., H. Lambright, and A. Teich, "The Future Role of Government Laboratories," presented at Seminar Series on the Changing Structure of the U.S. Research System, George Washington University, Washington, D.C., May 1983.

Witten, A. J., "Shallow Applications of Geophysical Diffraction Tomography," presented at Schlumberger-Doll Research, Ridgefield, Conn., June 1983.

\subsection{PROFESSIONAL ACTIVITIES AND AWARDS}

Baxter, V. D., recipient, 1982 Willis H. Carrier Award.

Baxter, V. D., Chairman, ASHRAE Task Group on Latent Source Heat Pumps.

Broders, M. A., Vice Chairman, Design Control Working Group of the ANSI/ASME Committee on Nuclear Quality Assurance.

Broders, M. A., participating member, ANSI/ASME Committee on Nuclear Quality Assurance.

Carnes, S. A., Reviewer, Risk Analysis: An International Journal.

Chen, F. C., member, ASME Systems Analysis Technical Committee on Advanced Energy Systems.

Courville, G. E., Chairman, U.S. Department of Energy Thermal Mass Review Panel.

Courville, G. E., member, Organizing Committee, Thermosense VII: International Conference on Thermal Infrared Sensing Diagnostics.

Courville, G. E., Program Chairman, ASHRAE TC 1.2, Measurements and Instruments.

Courville, G. E., Program Chairman, ASHRAE TC 4.4, Thermal Insulation and Moisture Retarders.

Courville, G. E., member, ABBE Committee on Diagnostics.

Courville, G. E., member, ASTM C-16.

Creswick, F. A., Vice Chairman, ASHRAE TC 7.6, Unitary Heat Pumps and Air Conditioners.

DeVault, R. C., Chairman, Heating and Cooling Session I-Absorption Heat Pumps, 18th Intersociety Energy Conversion Engineering Conference, Orlar.do, Fla., Aug. 21-26, 1983. 
Ellison, R. D., Chairman, ASHRAE TC 8.4, Air to Refrigerant Heat Transfer Equipment.

Fairchild, P. D., Chairman, Research Subcommittee, ASHRAE TC 9.4, Applied Heat Fump/Heat Recovery Systems.

Fairchild, P. D., member, ASHRAE TC 1.8.

Fairchild, P. D., member, Gas Research Institute Heat Pump Advisory Committee.

Gilmore, C. C., member, Technical Program Committee for the 1983 Annual Meeting and Exhibition of the Air Pollution Control Association, Atlanta, June 1983.

Greene, D. L., Chairman, Committee on Energy Conservation and Transportation Demand, Transportation Research Board, National Academy of Sciences/National Research Council.

Greene, D. L., member, Transportation Information Systems and Data Requirements Co.nmittee, Transportation Research Board, National Academy of Sciences/National Research Council.

Greene, D. L., Organizer and Chair of Session, Transportation Energy Modeling Project, Session 160, 62nd Annual Meeting Transportation Research Board, Washington, D.C., January 1983.

Haynes, V. O., member, Gas Research Institute Appliance Advisory Committee.

Hunsaker, D. B., Jr., memider, Technical Program Committee for the 1983 Annual Meeting and Exhibition of the Air Pollution Control Association, Atlanta, June 1983.

Kaplan, S. I., Technical Advisor, Solar Energy Panel, U.S. Energy Research Advisory Board.

Kaplan, S. I., member, Evaluation Panel for DOE Photovoltaic Application Experiments.

Lee, D. W., Reviewer, American Society of Civil Engineers, Hydraulics Division, Committee on Groundwater Hydrology.

Lee, D. W., Reviewer, Nuclear Safety.

Lee, R., Chairman, Research Committee, Energy Specialty Group, Association of American Geographers.

Levins, W. P., member, ASHRAE Standards Committee 41.4-75R, Oil in Refrigerants.

Levir.s, W. P., member, ASHRAE TC 1.2, Instruments and Measurements.

McConnell, B. W., Secretary-Treasurer, Oak Ridge Section of the IEEE.

McConnell, B. W., member, Tennessee Technological University Electrical Power Advisory Committee.

Mei, V. C., Reviewer, ASME Journal of Solar Ënergy Engineering.

Michel, J. W., alternate, Gas ?esearch Institute Heat Pump Advisory Committee.

Michel. J. W., member, Seothermal Coordinating Committec, U.S. Department of Energy.

Mixon, W. R., Chairman, Public Awareness Symposium, WATTec, Knoxville, Tenn., Feb. 23-25, 1983.

Mixon, W. R., ORNL Representative, International District Heating Association.

Mixon, W. R., member, Gas Research Institute Energy Cogeneration Systems Project Advisory Group.

Perez-Blanco, H., member, ASHRAE TC 8.3, A bsorption and Heat-Operated Machines.

Perez-Blanco, H., Reviewer, American Society of Heating, Refrigerating, and Air-Conditioning Engineers.

Privon, G. T., member, ASHRAE TC 8.I, Positive Displacement Compressors. 
Privon, G. T., member, ASHRAE TC 8.11, Motors and Motor Protection.

Purucker, S. L, member, IEEE Long-Range Distribution System Design Working Group.

Rayner, S. F., Corresponding Editor, Research Papers Series, Centre for Occupational and Community Research, Middlesex, United Kingdom.

Reddoch, T. W., Associate Editor, Electric Power Systems Research.

Reddoch, T. W., Associate Editor, Journal of Wind Energy.

Reddoch, T. W., member, IEEE Load Mánagement Working Group.

Ǩeddoch, T. W., member, IEEE Subcommittee on Systems Control.

Reed, A. W., member, Ecology Conmittee, Water Pollution Control Federation.

Rizy, D. T., member, IEEE Standards Coordinating Committee on Dispersed Storage and Generation.

Roop, R. D., member, Ecology Committee, Water Pollution Control Federation.

Shapira, H. B., Chairperson, Technology Transfer Group, Building Thermal Envelope Coordinating Council (BTECC) Committee on Fenestration.

Shapira, H. B., member, Building Thermal Envelope Coordinating Council (BTECC) Committee on Passive Solar Systems.

Shapira, H. B., affiliate, American Institute of Architects.

Soderstrom, E. J., Reviewer, Evaluation and Program Planning.

Soderstrom, E. J., Reviewer, Transactions of the American Fisheries Society.

Soderstrom, E. J., appeared in Who's Where Among Writers.

Sorensen, J., member, Field Study Team, Committee on Natural Disasters, National Research Council.

Southworth, F., member, Urban Goods Movement Committee, Transportation Research Board, National Academy of Sciences/National Research Council.

Southworth, F., Organizer of Contributed Paper Sessions, Annual North American Regional Science Association Meetings, Pittsburgh, November 1982.

Southworth, F., International Program Committee, Symposium on New Directions in Urban Modeling, University of Waterloo, Ontario, Canada, July 1983.

Stovall, J. P., member, IEEE Distribution System Design Working Group.

Vineyard, E. A., Chairman, ASHRAE Symposium on Energy Efficiency Developments in Residential Water Heating.

Vineyard, E. A., Program Chairman, ASHRAE TC 6.6, Service Water Heating.

Vineyard, E. A., Program Chairman, ASHRAE TC 7.1, Domestic Refrigerators and Food Freezers.

Vineyard, E. A., member, Gas Research Institute Appliance Advisory Committee.

Vineyard, E. A., Reviewer, American Society of Heating, Refrigerating, and Air-Conditioning Engineers.

Wilbanks, T. J., Advisory Editor, Syracuse Gengraphical Series.

Wilbanks, T. J., Association Representative to Section K (Social, Economic, and Political Sciences) of the American Association for the Advancement of Science, Association of American Geographers. 
Wilbanks, T. J., corresponding mermber, Commission on Regional Systems and Policies, International Geographical Union.

Wilbanks, T. J., member, Advisory Board, project on "The Regional Censequences of Large-Scale Energy Developmetit," International Institute for Applied Systems Analysis (IIP.SA).

Wilbanks, T. J., member, Advisory Committee, ESPER Network (Energy/Environmen: Social Perspectives).

Wilbanks, T. J., member, Advisory Committec, Resource Publication Series, Association of American Geographers.

Wilbanks, T. J., member, Advisory Committee, ESPER Journal (Energy/E-ivironmental Social Perspectives).

Wilbanks, T. J., member, Board of Visitors, Graduate School of Planning, University of Tennessee.

Wilbanks, T. J., member, Committee on Behavioral and Social Aspects of Energy Consumption and Production, National Academy of Sciences/National Research Council.

Wilbanks, T. J., member, Working Group on Energy, International Geographicai Union.

Wilbanks, T. J., member, Selection Committee for Fulbright Fellows in Geography, Council for the International Exchange of Scholars.

Wilbanks, T. J., Presented testimony to the Subcommittee on Energy Deveiopment and Applications of the U.S. House Committee on Science and Technology, Mar. 10, 1983.

Wilbanks, T. J., Reviewer, Annals. Assaciation of American Geographers; The Professional Geographer; and Journal for Risk Analysis.

\subsection{WORKSHOPS AND SYMPOSIA ORGANIZED BY ENERGY DIVISION STAFF}

Fourth and Fifth Annual DOE LLWMP Participants Information Meetings, Denver, Aug. 31-Sept. 2, 1982, and Aug. 30-Sept. 1, 1983, organized by L. J. Mezga.

New Product Develnpment Workshop, Conference Center, Baltimore, Oct. 14-25, 1982, organized by $\mathrm{E}$. J. Soderstrom and M. L. Rorke.

Thermosense V: International Conference on Thermal Infrared Sensing Diagnostics, Detroit, Oct. $25-27,1982$, chaired by T. S. Lundy.

Financing Inventions Workshop, Los Angeles, Nov, 9-1C, 1982, organized by E. J. Sodersirom and M. L. Rorke.

Conference on the Improvement of the Quality of Data Collected by Data Collection Systems, Oak Ridge, Tenn., Nov. 11-12, 1982, organized by D. A. Gardiner, A. S. Loebl, and T. Wright.

DOE Contractors' Review of Electric Field Effects, Denver, Nov. 15-17, 1982, organized by T. W. Reddoih.

ASHRAE/DOE Conference on Thermal Performance of the Exterior Envelopes of Buildings II, Las Vegas, Dec. 6 9, 1982, organized by T. S. Lundy.

Licensing Inventions Workshop, Chicago, Dec. 7-8, 1982, organized by E. J. Sxderstrom and M. L. Rorke.

Transportation Energy Modeling Project, Session 160, 62nd Annual Meeting, Transportation Research Board, Washington, D.C., January 1983, organized by D. L. Greene. 
1983 International Daylighting Conference, Phoenix, Ariz, Feb. 16-18, 1983, T. S. Lundy on Plarning/Policy Committee (cosponsored with AIA, ASHRAE, EEI, EPRI, IES, and CIE).

Waste Management 83, Tucson, Ariz, Feb. 27-Mar. 3, 1983, session (Special Considerations in Low-Level Radwaste Processing and Disposal) chaired by L. J. Mezga.

Practice, Problem-Solving, and Skills Development for Energy Program Evaluation-A Pilot Workshop for States, Salt Lake City, Mar. 1-3, 1983, organizel by N. E. Collins.

1983 Annual Meeting and Exhibition of the Air Pollution Control Association, Atlanta, June 1983, Session 2 (Atmospheric Emissions \& Impacts on Agricultural and Forestry Activities) chaired by C. C. Gilmore.

1983 Annual Meeting and Exhibition of the Air Pollution Control Association, Atlanta, June 1983, Sessions 19 (Environmental Auditing) and 20 (Air Pollution Control Program Administration) chaired by D. B. Hunsaker, Jr.

DOE Contractors' Review of the Athens Automation and Control Experiment, Dallas, June 8-10, 1983, organized by T. W. Reddoch and S. L. Purucker.

Practice, Problem-Solving, and Skills Development for Energy Program Evaluation-A Workshop for States, Providence, R.I., July 13-14, 1983, organized by N. E. Collins.

Practice, Problem-Solving, and Skills Development for Energy Program Evaluation-A Workshop for States, Philadelphia, Sept. 18-21, 1983, organized by N. E. Collins.

\subsection{ENERGY DIVISION CONSULTANTS AND SUBCONTRACTORS}

\subsubsection{Consultants}

P. R. Achenbach

F. Arumi-Noe

H. W. Askins

M. Athans

J. W. Blaylock

H. W. Bushing

J. D. Clark

P. L. Fisher

W. F. Fitzgerald

G. Flynn

D. A. Freedman

F. Goldberg

D. Goldenberg

R. L. Gordon

J. J. Grainger

L. L. Grigsby

G. Grossman

D. T. Harrje

J. A. Hausman

J. F. Helmut

L. B. Jocic

D. R. Johnson

R. C. Johnson
D. L. Kaserman

D. E. Kash

E. G. Keshock

W. C. Labys

P. E. Lambert

W. H Lambright

A. J. Laub

T. A. Lipo

R. N. Lyon

R. L. Marsh

W. R. Martini

J. Mayo

J. McCorkle

S. L. McDonald

J. M. McIntyre

K. M. McKechan

L. F. Menendez

W. T. Miles

D. Mile! $i$

J. A. Mosell

G. W. Morrison

L. Nall

R. D. Nininger 
F. M. O'Hara

J. B. Patton

A. G. Phadke

R. C. Robertson

J. H. Schuenemeyer

W. L. Smaliey

V. K. Smith

R. W. Stafford

W. F. Stoecker

R. L. Sullivan

A. H. Teich
R. J. Thomas

E. F. Vance

T. Vonier

H. L. Waehler

G. Walker

B. P. Wang

D. Watson

A. D. Watts

R. L. Webb

E. P. Wigner

C. C. Wilson

\subsubsection{Subcontractors by Company}

A. F. Meyer \& Associates, Inc. Adams, Craft, Herz \& Walker

Advanced Mechanical Technology, Inc.

Aeronautical Research Associates

Allen \& Hoshall, Inc.

Allied Chemical Corporation

American Conssilting Engineers Council

Research and Management Foundation

Analytic Disciplines, Inc.

Analytic Science Corporation

Analytic Systems, Inc.

Andrulis Research Corporation

Applied Management Sciences, Inc.

Argonne National Laboratory

Arkla Industries, Inc.

Arthur D. Little, Inc.

Association of Collegiate Schools

of Architecture, Inc.

Athens Utility Board

Automation Management Consultants I

Battelle Columbu; Laboratories

Booz, Allen \& Hamilton, Inc.

Brooklıaven National Laboratory

Brown Boveri Control Systems, Inc.

C. F. Systems

California Institute of Technology

Camden Corporation

Camp, Dresser, \& McKee, Inc.

Carnegie Mellon University

Carrie: Corporation

Charles River Associates, Inc.

Charles Stark Draper Laboratory, Inc.

Clemson University

Colliers Management Corporation

Colorado Nuclear Corporation

Colorado School of Mines

Colorado State University

Computer Sciences Corporation
Computer Security Institute

CONSAD Research Corporation

Consolidated Natural Gas Research

(CNG) Corporation

Context International, Inc.

Cristy Consultants, Inc.

Dames \& Moore

Decision Analysis Corporation

Decision Focus, Inc.

Delta Electronic Control Corporation

Department of Army, Cold Regions

Research \& Engineering Laboratory

DHD, Inc.

ESG Associates

East Tennessee State University

Energy Concepts Unlimited, Inc.

Enerzy Research Application Systems

(ERAS), Inc.

Energy Resource Management 83

Energy Resources Company, Inc.

Energy Systems Group, Inc.

Evaluation Research Corporation

Facility \& Manufacturing Automation, Inc.

Fredrick A. Costello, Inc.

General Electric Company

George Washington University

Georgia Technology Research Institute

Greenville Products Company

Gruy Federal, Inc.

Gruy Petroleum Technology, Inc.

Health Systems Research Associates

Honeywell, Inc.

ICF, Inc.

International Energy Associates, LTD

JBF Associates

Kilkeary, Scott \& Associates, Inc.

L. D. Ridgeway, Inc.

Lawrence Livermore National Laboratory 
Lockheed Missiles \& Space Company, Inc.

Long Island Lighting Company

Mantech International Corporation

M:rtini Engineering

Massachusetts Institute of Technology

Mathtec

MAXIMA Corporation

McGraw-Edison Power Systems Group

McGraw-Hill Informaton Systems, Inc.

Mechanical Technology, Inc.

Metretek

Michigan State University

Minnesola Department of Energy

Mohawk Research Corporation

National Academy of Sciences

National Aeronautics Space Administration

(NASA-Lewis Research Center)

National Bureau of Standards

National Fenestration Council

National Roofing Contractors Association

Native American Consultants, Inc.

North Carolina State University

Northeast-Midwest Institute

Nuclear Assurance Corporation

Nuclear Resources International

Omaha Public Power District

Pennsylvania State University

Performance Development Corporation

Phillips Engineering Company

Planning Research Corporation

Portland Cement Association

Putnam, Hayes, \& Bartlett, Inc.

Radian Corporation

Regional Systems Services Group, Inc.
Research Triangle Institute

Resource Consulting Group, Inc.

Resource Dynamies Corporation

Resources for the Future. Inc.

S. M. Stoller Corporation

Sage Systems, Inc.

Science Applications, Inc.

Simcon, Inc.

Stevens Institute of Technology

Swanson, Callaban \& Company

Synergic Resources Corporation

Syracuse Research Corporation

Systems Control, Inc.

Technion-Israel Institute of Technology

Technology Management Corporation

Tectonies Research, Inc.

Tennessee Technotogical University

Trane Company

TRW Inc.

University of California

University of Idaho

University of Illinois

University of Minnesota

University of New Mexico

University of Oklahoma

University of Pittsburgh

University of Tennessee

University of Wisconsin

W. R. Grace \& Company

W. S. Fleming \& Associates

Warren Glimpse \& Company

Westinghouse Electric Corporation

Whittaker Corporation

Zaininger Engineering Company

\subsection{PUBLICATIONS BY SUBCONTRACTORS}

Ackermann, R. A., J. D. English, and T. M. Moynihan. Mechanical Technology, Inc., "Stirling Engine Heat-Actuated Heat Pump," pp. $184 n-43$ in Proceedings of the $181 \mathrm{~h}$ IECEC, vol. 4, American Institute of Chemical Engineers, New York, 1983.

Analytic Sciences Corporation, Alternative Finding Rate Formulations for Non-Associated Gas Supply Matels-Final Report. Oct. 30, 1982.

Applied Management Sciences, Inc., A Comparative Analysis of Business Graphics Software Packages, February 1983.

Applied Mnnagernent Sciences, Inc., Development of Automated Information Systems for the U.S. Naval Sea Systenis Command: Budget and Financial Accounting System Requirements, Apr. 18, 1983.

Applied Management Sciences, Inc., Development of Automated Information Systems for the U.S. Naval Sea Systems Command: Minimum Environmental Requirements for Seven Field Activity Groups. June 15, 1983. 
Applied Management Sciences, Inc., Development of Automated Information Systems: Comparison of Database Models for Application tc the Ship Alteration Management Information System, Apr. I, 1983.

Applied Management Sciences, Inc., Development of Automated Information Syster.s: DSA Dacument Distribution DBMS Preliminary Desigm, Jan. 21, 1983.

Appliad Management Sciences, Inc., Development of Automated Information Systems: Navy Leased Communications Management System Phase II (NLCMS II). Functional Description, May 1983.

Applied Management Sciences, Inc., Development of Automated Information Systeins: Navy Leased Communications Management System Phase II (NLCMS). Users Manual, May 1983.

Applied Management Sciences, Inc., Development of Automated Information Systems: Preliminary AMDAHL to Four Phase Cormunications Test Plan, Feb. 24, 1983.

Applied Management Sciences, Inc., Evaluation of Electronic Mail Packages for Application to the Ship Alteration Management Information System User Community. Mar. 22, 1983.

Applied Management Sciences, Inc., IBM 4331 Management Plan (NAVSEA 070). Aug. 31, 1983.

Applied Management Sciences, Isic., Navy Leased Communications Management System: Phase II (.NLCMS). Functional Description, Aug. 22, 1983.

Applied Management Sciences, Inc., SAMIS Alternatives for SPCC: An Assessment of Current Technologies, Aug. 17, 1983.

Applied Management Sciences, Inc., SAMIS Full Screen Application Support, Aug. 1, 1983.

Applied Sciences Group, A Review and Critique of the Specifications Governing Design. Performance. R\&M Evaluation and Test for U.S. Navy Ejection Seat Type AAES, Sept. 18, 1983.

Applied Sciences Grnup, Analysis of the Reported liccidents of Windblast, Flail, and Tumble During Ejection, Aug. 4, 1983.

Ball, D. A., R. D. Fischer, and D. A. Hodgett, "D-sign Methods for Ground Source Heat Pumps," ASHRAE Trans. 89(2b), 416-39 (1983).

Bernardi, W. P., R. P. Blevins, and B. D. Sloane, Energy Utilization Systems, Inc., Examination and Life Assessment of Field-Tested Heat Pump Wate, Heaters, ORNL/Sub-7321/5, Oak Ridge National Laboratory, December 1982.

Blaylock, J. W., Computer Performance Evaluation and Capacity Planning for Sperry 1100 Compuler Systems, Aug. 31, 1983.

Bloomsburg, G., and R. E. Williams, Hydrogeologic Analysis of Union Carbide's A-9 Pit, East Gas Hills, Wyoming. Mineral Resources Waste Management Team Report, September 1983.

Borhanian, H., and S. Hynek, Foster-Miller Associates, Inc., Demonstration of a Low-Temperature Woste Heat Driven Refrigeration System: Phase III, Final Report, ORNL/Sub/80-28906/2, Oak Ridge National Laboratory, September 1983.

Boteilho, R. J., Evaluation Research Corporation, Integrated Signals Intelligence System Level of Repair Analysis, September 1983.

Boteilho, R. J., Evaluation Research Corporation, Marine Corps Level of Repair (MCLOR) Analysis Program Familiarization Seminar, Aug. 8, 1983.

Boteilho, R. J., and E. R. Berger, Evaluation Research Corpuration, Marine Corps Level of Repair (MCL.OR) Installation Manual. November 1982. 
CONTEXT International, Inc., Current Functional Requirements of the User Community for NIFRS, Feb. 2, 1983.

CONTEXT International, Inc., Current Operating Environment of NIFRS, Feb. 16, 1983.

CONTEXT International, Inc., Functional Description of the Conversion of NIFRS, Apr. 30, 1983.

CONTEXT International, Inc., Hardware and Software Analysis Re a Redesigned NIFRS, Mar. 10, 1983.

Chang, Te-Chuan, and H. W. Busching, Energy Savings Potential of Roofing Research, Clemson University, P.O. 19X22293V, August 1983.

Charles River Associates, Comparison of Natural Gas Models: Task 1- Identification of Models of the Natural Gas Market, December 1982.

Charles River Associates, Comparison of Natural Gas Models: Task 2-Outline of Phase I Report, July 1983.

Charles River Associates, Comparison of Natural Gas Models: Task 3-Assessment of Leading Models of the Natural Gas Market, January 1983.

Charles River Associates, Comparison of Natural Gas Models: Task 5-Economic Structure. Regulatory Assumptions, and Empirical Implementation, March 1983.

Charles River Associates, Comparison of Natural Gas Models: Task 6-Interim Report-Forecasting Properties of the TERA Model, December 1982.

Colleries Management Corporation, Relationship Between the Costs of Temporary Shutdown, Mothballing, Standby, and Reopening of Uranium Mines and Mills in the U.S., April 1983.

Colleries Management Corporation, Standardized Cost Expectations Associated with the Temporary Shutdown. Mothballing, Standby and Reopening of Uranium Mines and Mills in the U.S., April 1983.

Colorado Nuclear Corporation, Data Base for the Internotional EUREKA Model, May 16, 1983.

Computer Sciences Corporation, Cartridge Actuated Device (CAD) Requirements Test Reports. Aug. 26, 1983.

Computer Sciences Corporation, Program Objectives Memorandum (POM) Formulation Test Reports, Aug. 26, 1983.

Computer Sciences Corporation, War Reserve Material Test Reports, Sept. 21, 1983.

Decision Analysis Corporation, 1981 Sales-for-Resale Volumes by Purchasers (FERC Form 2). January 1983.

Decision Analysis Corporation, Analysis of Interstate Pipeline Industrial Sales Agreements-Minimum Bill Dala Collection Forms, July 1983.

Decision Analysis Corporation, Analysis of Interstate Pipeline Sales Agreements-Final Report: Summary of Industrial Sales Minimum Bill Research Results, August 1983.

Decision Analysis Corporation, Analysis of Interstate Pipeline Sales Agreemen/s-Pipeline Reports, February 1983.

Decision Analysis Corporation, Analysis of Interstate Pipeline Sales Agreements-Pipeline Reports, November 1982.

Decision Analysis Corporation, Field and Main Line Industrial Sales of Natural Gas (FERC Form 2), January 1983. 
Decision Analysis Corporation, Study of Interstate Pipeline Sales Agreements: Methodology for Subtask I-Statistical Analysis of Pipeline Company Sales Agreements, Ottober 1982.

Dugan, R. C., and W. T. Jewell, Computer Simulation Harmonics Study: Analysis of the Effects on Two Distribution Feeders of Harmcnics Produced by the Proposed John F. Long 100-House Photovoltaic Development, Interim Report, ORNL/Sub/81-95011/1, Oak Ridge National Laboratory, August 1983.

Dugan, R. C., T. R. Fisher, G. Gilker, J. A. Kischefsky, C. D. Ko, S. A. Thomas, and V. Y. Tong, Protection of Electric Distribution Systems with Dispersed Storage and Generation (DSG) Device:, ORNL/CON-123, Oak Ridge National Laboratory, September 1983.

ESG Associates, Inc., An Automated System to Link the International Energy Data Base and International Energy Annual Tables. Apr. 11, 1983.

ESS Associates, Inc., An Automated System to Produce Maps Showing World-Wide Flows of Energy Commodities, Mar. [6, 1983.

ESG Associates, Inc., Computer Graphics System for World Oil Outlook Tables: User's Manual, Feb. 10, 1983.

ESG Associates, Inc., Design of Tables and Graphs to Be Produced from the International Energy Data Base, Feb. 14, 1983.

ESG Associates, Inc., First Set of Enhanced Management Reports Produced fromt the International Energy Data Base, Aug. 12, 1983.

ESG Associates, Inc., Improved Procedures for Computer Generation of Maps Showing International Trade in Crude Oil, Coal, and Natural Gas, July 15, 1983.

ESG Associates, Inc., Improved Procedures for Updating the International Energy Data Base with New Quarterly Oil Statistics Data, vols. I and II, June 10, 1983.

ESG Associates, Inc., Improvements in Publication Activities Through Use of the International Energy Data Base. Nov. 29, 1982.

ESG Associates, Inc., Management Reports Produced from the International Energy Data Base. Apr. 15, 1983.

ESG Associates, Inc., Mathods for Generating Management Reports from the International Energy Data Base, Apr. 15, 1983.

ESG Associates, Inc., Possibilities for Improvement in Analytic Capahilities, Dec. 29, 1982.

ESG Associates, Inc., Procedure to Ensure Consistency of Reports Produced from the International Energy Data Base, Sept. 30, 1983.

ESG Associates, Inc., Second Set of Enhanced Management Reports Produced from the International Energy Data Base (Volumes I and II), Sept. 30, 1983.

ESG Associates, Inc., Seminar Notes on Use of the International Energy Data Base, Jan. 31, 1983.

Enscore, E. E., Jr., R. L. Gordon, and A. L. Soyster, George Washington University, Developme... and Studies for a Short-Term Coal Supply Model for the Intermediate Future Forecasting System (IFFS), Firal Report Volumes I and II, Apr. 15, 1983.

Evaluation Research Corporation, Computerization of Form ElA-64A Frame-System Documentation. Jan. 20, 1983.

Evaluation Research Corporation. Development of the TEPACS Information Processing System (TIPS)--System Design Specification, May 1983. 
Evaluation Research Corporation, Form ElA-64A System Assessment-Draft Final Report, Feb. 22, 1983.

Evaluation Research Corporation, Form EIA-64A System Assessment-Extended System Assessmont. Oct. 25, 1982.

Evaluation Research Corporation, Form EIA-64A System Assessment-Final Report, Mar. 22, 1983.

Evaluation Research Corporation, Review of Manual and Automated Data Handling Procedures-Natural Gas: Alternative Fuel Demand Due to Natural Gas Deficiencies Repon (FERC-50)-Final Report, Apr. 29, 1983.

Evaluation Research Corporation, Review of Manual and Automated Data Handling Procedures-Natural Gas: Interstate Pipelines' Annual Repon of Gas Supply-FERC-IS, June 3, 1983.

Evalvation Research Corporation, Review of Manual and Automated Data Handling Procedures-Natural Gas: Natural Gas Pipeline Company Monthly Statement (FERCIi)-Final Report, July \&, 1983.

Evaluation Research Corporation, Standards Review of the Monthly Petroleum Supply Reporing System, Sept. 21, 1983.

Evaluation Research Corporation, Standards Review of the Petroleum Supply Reporting System-Task Management Plan, July 22, 1983.

Facility and Manufacturing Automation, Inc., Aerial Infrared Thermography: A Review of Three DOE-Sponsored Projects, Final Report, March 1983.

Fagan, T. J., Westinghouse Electric Corp., "Annual Ownership Costs for High-Efficiency Heat Pumps in Well-Insulated Residences," Proceedings of Heat Pump Technology Conference. CONF-821151-1, OkJahoma State University, Stillwater, 1982.

Falk, J. E., and G. P. McCormick, George Washington University, A Differentiable Approximation to the Supply Curves, Aug. 11, 1983.

Falk, J. E., and G. P. McCormick, George Washington University, Examples of Several Oligopoly "Solutions," May 17, 1983.

Falk, J. E., and G. P. McCormick, George Washington University, User's Manual for the International Coal Trade Model, May 16, 1983.

Fiorato, A. E., "Evaluation of Thermal Mass Effects in Buildings Using Laboratory Tests," pp. 225-64 in Proceedings of the Building Thermul Mass Seminar 1982, ed. G. E. Courville and E. L. Bales, CONF-8206130, Oak Ridge National Laboratory, August 1983.

Fitzgerald, W. M., Independent Expert Review of "Investor Perceptions of Nuclear Power." May 26, 1983.

Fitzgerald, W. M., Independent Expert Review of "Model Documentation for 9 DGEM: The 9 Sector Dynamic General Equilihrium Model," Mar. 30, 1983.

Frank, H. J., Independent Expert Review of Energy Prices and Expenditures Data Report: 1970 1980," Mar. 37, 1983.

Fre dman, D. A., A Review of Two Approaches to Modeling Midterm Energy Demand-Final Report, March 1983.

Freedman, D. A., Bootstrapping an Econometric Model: Some Empirical Results-Final Report, March 1983. 
Gordon, R. L., Independent Expert Keview of "DOE Model Documentation, The National Coal Model (Volume IV)." Apr. 27, 1983.

Gordon, R. L., Independent Expert Review of "DOE Model Documentation, The National Coal Model (Volumes I. II, and III)," Apr. I, 1983.

Greene, D. L., R. Barnes, R. Lee, and TERA Associates, An Overview of the Wharton School Assessments of the Short-Term Integrated Forecasting System, DOE/NBB-0046, Energy Information Administration, U. S. Department of Energy, July 1983.

Gruy Petroleum Technology, Inc., Disaggregate/Unconventional Natural Gas Analysis: Compilation and Processing of OCS Production Data, Sept. 1, 1983.

Gruy Petroleum Technology, Inc., Disaggregate/Unconventional Natural Gas Analysis: Correlations for Determining Hydrocarbon Recovery from Impermeable Gas Reservoirs, June 3, 1983.

Gruy Petroleum Technology, Inc., Disaggregate/Unconventional Natural Gas Anulysis: Correlations for Projecting Production from Tight Gas Reserwoirs-Final Report, July 20, 1983.

Gruy Petroleum Technology, Inc., Disaggregate/Unconventional Natural Gas Analysis: Design of a Computer Model for Projecting Drilling and Production in Tight Gas Sands, Dec. 30, 1982.

Gruy Petroleum Technology, Inc., Disaggregate/Unconventional Natural Gas Analysis: Design of a Model for P. ojecting Drilling and Production of Devonian Shale Gas, Mar. 24, 1983.

Gruy Petroleum Technology, Inc., Disaggregate/Unconventional Natural Gas Analysis: Initial Data Base for Tight Gas-Appendix Data Pages, July 15, 1983.

Gruy Petroleum Technology, Inc., Disaggregate/Unconventional Natural Gas Analysis: Initial Data Base for Tight Gas, Nov. 3, 1982.

Gruy Petroleum Technology, Inc., Disaggregate/Unconventional Natural Gas Analysis: Modeling the Profitability of Drilling for Tight Gas and Devonian Shale Gas, Aug. 10, 1983.

Gruy Petroleum Technology, Inc., Disaggregate/Unconventional Natural Gas Analysis: Regional Profiles of Oil and Gas Production, Sept. 6, 1983.

International Energy Associates Limited, A Study of Decommissioning Data in the U.S., France. Sweden, Switzerland, Japan, and Germany for Light-Water Reactors-Final Report, December 1982.

International Energy Associates Limited, Analysis of Foreign Uranium Supply in the Intermediat? Term 1982-2000: Task I-Production Center Identification and Characterization, July II, 1983.

Labys, W. C. Independent Expert Review of "On Domestic Petroleum Drilling," Nov. 29, 1982.

Lawton, E. A., L. Irwin, A. Lawler, and L. N. Bohanan, Shock Hydrodynamics Division, Whittaker Corp., Highly Efficient Commercial Pulse-Combustion Gas-Fired Water Heater-R\&D Report. ORNL/Sub/79-24711/1, Oak Ridge National Laboratory, December 1982.

MAXIMA Corporation, Appendix C: Printout of the Western (Raw) Demonstrated Reserve Base by Coalbed, Rank and Type of Mining, October 1982.

Martini, W. R., "A Revised Isothermal Analysis Program for Stirling Engines," pp. 743-48 in Proceedings of the 18th IECEC, vol. 2, American Institute of Chemical Engineers, New York, 1983. 
Mathtech, Appendix X: WINES Methadology-Appendix to the DOE Commercial Nuclear Power Report, April 1983.

Mathtech, World Energy Forecasting: Methodologie:" and Recommended Strategies, March 1983.

Mathtech, World Integrated Nuclear Evaluation System (WINES)-Users Guide and Model Documentation Report, April i983.

McDonald, S. L., Independent Expert Review of "An Analysis of the Crude Oil Windfall Profit Tax," Nov. 11, 1983.

Metz, P. D., -Ground-Coupled Heat Pump System Experimental Results," ASHRAE Trans. 89(2b), 407-15 (1983).

Middleton, M. C., and R. S. Sauber, Kelvinator Compressor Co., Research and Development of Energy-Efficient Appliance Motor-Compressors: Volume IV-Production Demonstration and Field Test. ORNL/Sub/78-7229/4, Oak Ridge National Laboratory, September 1983.

Murphy, K. P., and B. A. Phillips, "Development of a Residential Gas Absorption Heat Pump," pp. 1911-14 in Proceedings, 18th Intersociety Energy Conversion Engineering Conference, vol. 4, American Institute of Chemical Engineers, New York, August 1983.

Nall, D. H., Independent Expert Review of Methodological Issues in the Non-Residential Buildings Energy Consumption Survey," July 29, 1983.

Native A:nerican Consultants Inc., Data Flow Withir the Short-Term Integrated Forecasting. July $20,1183$.

Native American Consultants Inc., Review of Existing Information Related to Short-Term Forecast Evaluation for DOE/EIA, Feb. 18, 1983.

Native American Consultants Inc., Software Tools for Consistency Review of STIF/STEO Forecasts and Historical Data, June 1983.

Nelson, J. D., R. E. Wardwell, S. R. Abt, and W. P. Staub, Consolidation of Tailings, NUREG/CR-3204, U.S. Nuclear Regulatory Commission, ORNL/TM-8690, Oak Ridge National Laboratory, September 1983.

Nelson, J. D., R. L. Volpe, R. E. Wardwell, S. A. Schumm, and W. P. Staub, Design Considerations for Long-Term Stabilization of Uranium Mill Tailings Impoundments, NUREG/CR-3397, U.S. Nuclear Regulatory Commission, ORNL-5979, Oak Ridge National Laboratory, September 1983.

Nguyen, H. T. N., A New Aggregation Methodology Applied to Residential Air Conditioner Loads, ORNL/Sub/79-7685/2\&40, Oak Ridge National Laboratory, February 1983.

Nortneast-Midwest Institute, Federal Energy Information Requirements, Apr. 11, 1983.

Nuclear Assurance Corporation, Near-Term Plutonium Market Outlook, March 1983.

Nuclear Assurance Corporation, U.S. Spent Fuel Storage Analysis_Final Report, March 1983.

Nuclear Resources International, Enrichment/Uranium Market Interactions: Utility Inventory Policies, July 1983.

Oak Ridge Associated Universities, A Reevaluation of the Supply and Disposition of Natural Gas System-Final Report, March 1983.

Oak Ridge Associated Universities, An Evaluation of Natural Gas Storage Data. January 1983.

Oakes, E. H., and A. H. Voelker, Wilderness Designation of BLM Lands and Impacts to the Availability of Eneräy Resources, ORNL/TM-8310, Oak Ridge National Laboratory, February 1983. 
Performance Development Corporation, Evaluation and Recommendation for OP-90 Software and Hardware for Office of Chief of Naval Operations OP-90IM, June 24, 1983.

Planning Research Corporation, DRD Metadata Public Use Energy Statistics Data Base Linkage. October 1982.

Planning Research Corporation, DRD/PUE LDB Time Series Maintenance System Users Manual, February 1983.

Planning Research Corporation, Executive Summary: Suggestions for Standardization of EIA's Definitions of Energy Terms-I. Motor Gasoline Products, Feb. 23, 1983.

Planning Research Corporation, Information Retrieval (V2) Program Maintenance Manual, January 1983.

Planning Research Corporation, Information Retrieval (V2) System Specification Dacument. January 1983.

Planning Research Corporation, Information Retrievul Users Guide-Version 3, Apr. 4, 1983.

Planning Research Corporation, Time Series Maintenance System-Maintenance Manual, October 1982.

Planning Research Corporation, Time Series Maintenance System-Users Manual, October 1982.

Putnam, Hayes, \& Bartlett, Inc., Alternative Energy Futures: A Review of Low Energy Growth Forecasts and Least-Cost Planning Studies, June 1983.

Resource Dynamics Corporation, State Rulemaking and Utility Pricing for Cogeneration-Final Report, December 1982.

S. M. Stoller Corporation, Nuclear Industry Structure for the Energy Information Administration Nuclear Industry Data Requirements Review, June 10, 1983.

S. M. Stoller Corporation, Working Paper on Data Requirements and Federal Data Systems for Energy Information Administration Data Requirements Review. Aug. 5, 1983.

S. M. Stoller Corporation, Working Paper on Review of User Needs for the Energy Information Administration Nuclear Industry Data Requirements Reviews, June 24, 1983.

SIMCON Inc., Performance Work Statement-Code 50-Final Report, June 1983.

SIMCON Inc., Performance Work Statement-Code 501-Final Report. June 1983.

SIMCON Inc., Performance Work Statement-Code 501-Supporting Documentation, June 1583.

SIMCON' inc., Performance Work Statement-Code 502_Final Report, May 1983.

SIMCON Inc., Performance Work Statement-.Code 502-Supporting Documentation, June 1983.

SIMCON Inc., Performance Work Statement-Code 503-Final Report, May 1983.

SIMCON Inc., Performance Work Statement-Code 503-Supporting Documentation, June 1983.

SIMCON Inc., Performance Work Statement Project--Quality Assurance Surveillance, June 1983.

Schot,, J. R., J. D. Biegel, and E. F. Wilkinson, "Quantitative Aeria! Survey of Building Heat Loss," pp. 18794 in Thermai Infrared Sensing Diagnostics (Thermosense V), Proceedings SPIE 37I, ed. G. E. Courville, International Society for Optical Engineering, Belingham, Wash., April 1983.

Schuenemeyer. J. H., Independent Expert Review of "An Economic Analysis of Natural Gas Resources and Supply, and Related Documents," Apr. 1, 1983. 
Seddon, J., and C. H. Petrich, Case Studies: Developing Land Uses in Surface Mine Reclamation, OSM/TR-1-83, Office of Surface Mining, ORNL/TM-80i7, Oak Ridge National Laboratory, June 1983.

Seddon, J., and C. H. Petrich, Managemenl of Public Impacts in Surface Mining. ORNL/TM-7672, Oak Ridge National Laboratory, March 1983.

Stoney, W. E., Energy Systems Group, Independent Expert Review of The Cost Effectiveness of Solar and Conservation in New Home Construction," Feb. 16, 1983.

Synergic Resources Corporation, RAMC Surface Mining Cost Equations Development-Working Paper, February 1983.

Synergic Resources Corporation, RAMC Underground Mining Cost Equations Development-Workizg Paper. February 1983.

TRW Inc., An Evaluation of the EIA-764 Petroleum Product Sales Identification Survey, Mar. 30, 1983.

TRW Inc., An Overview of Procedures and Practices in Inter-Ltility Bulk Power Transactions, Mar. 4, 1983.

TRW Inc., Documentation/User's Guide for the EIA-764 Petroleum Product Identification Survey. Miar. 25, 1983.

TRW Inc., E1A-764-Survey Control System Users/Operators Guide, Mar. 18, 1983.

TRW Inc., E1A-764-Survey Processing Specifications for Automated Systems and Form Edits, Mar. 18, 1983.

TRK Inc., Report on Manual Verification of the Name and Address File for the EIA-764 Survey, Mar. 18, 1983.

TRW Inc., Representation of Bulk Power Transactions in the National Coal Model's Representation of Inter-Regional Bulk Power Transfer, Mar. 4, 1983.

TRW Inc., Some Observations Regarciing Modijucations to the National Coal Model's Representation of Inter-Regional Bulk Power Transfer, Mar. 4, 1983.

Technology Management Corporation/ManTech International Corporation, Configuration Management Plan (CMP) for the NAVWPNENGSUPP.ACT Integrated Production Management System (IPMS), Sept. 30, 1983.

Technology Management Corporation/ManTech International Corporation, Data Requirements (RD) for the NAVWPNENGSUPPACT Integrated Production Management System (IPMS), Ser:.. 30, 1983.

T=chnclogy Management Corporation/ManTech International Corporation, Functional Description (FD) for the NAVWPNENGSUPPACT Integrated Production Management System (IPMS), Sept. 30, 1983.

Technology Management Corporation/ManTech International Corporation, System/Subsystem Interface Specification for the NAVWPNENGSUPPACT Integrated Production Management System (IPMS), Sept. 30, 1983.

Terasawa, K. L., Independent Expert Revi'w of "The U.S.A. Net Exporter of Energy by the Year 2000?"- Apr. 12, 1983.

Topping, W. F., Development of a High-Efficiency, Automatic-Defrosting P.efrigerator-Freezer, Phase II-Field Test, ORNL/Sub/77-7255/3, Oak Ridge National Laboratory, December 1982. 
Toscano, W. M., D. H. Walker, and R. D. Tetreault, Research and Development of Highly Energy-Efficient Supermarket Refrigeration Systems, Volume 2-Supplemental Laboratory Testing. ORNL/Sub/80-61601/2, Oak Ridge National Laboratory, June 1983.

Vasilakis, A. D., J. Gerstmann, and E. A. Vineyard, "Design and Development Testing of an Improved High-Efficiency Water Heater," ASHRAE Trans. 8\%(1), 5-18 (1983).

Vasilakis, A. D., and J. Gerstmann, Development of a High-Efficiency Gas-Fired Water Heater. Phase II-Production Prototype Design and Development Executive Summary and Task Reports, ORNL/Sub/77-7381/3, Oak Ridge National Laboratory, April 1983.

Wang. Y., A Dynamic Model for an Induction Motor and Its Verification, ORNL/Sub/79-7685/1 \&40, Oak Ridge National Laboratory, February 1983.

Wardwell, R. E., J. D. Nelson, S. R. Abt, and W. P. Staub, In Situ Dewatering Techniques for Uranium Mill Tailings, U.S. Nuclear R:gulatory Commission, NUREG/CR-3202, U.S. Nuclear Regulatory Commission, ORNL/TM-8689, Oak Ridge National Laboratory, September 1983.

Wood, J. T., and R. A. Grot, "Description of a Facility for Evaluating Infrared Imaging Systems for Building Applications," pp. 246-49 in Thermal Infrared Sensing Diagnostics (Thermosense V). Proceedings SPIE 371, ed. G. E. Courville, International Society for Optical Engineering, Bellingham, Wash., April 1983.

Wright, N., J. D. Nelson, and G. Smith, Laboratory Testing of Hydrologic Characteristics of Soils and Tailings from the Union Carbide's A-9 Pit. Colorado State University Report, June 1983.

Zaininger, H. W., and P. R. Barnes, Investigate Alternative Interconnection Strategies for Arrays of Wind Turbine Generators, ORNL/Sub-82/69604/1, Oak Ridge National Labcratory, December 1982.

\subsection{INVITED SPEAKERS}

\begin{tabular}{ccc}
\hline \multicolumn{1}{c}{ Date } & \multicolumn{1}{c}{ Subject } & \multicolumn{1}{c}{ Speaker } \\
\hline $\begin{array}{c}\text { October 21, } \\
1982\end{array}$ & $\begin{array}{c}\text { Fearless Forecasting: How } \\
\text { the USGS Estimates Oil and }\end{array}$ & $\begin{array}{c}\text { A. B. Coury, Geologist } \\
\text { U.S. Geological Survey }\end{array}$ \\
Govember 2 & Advanced Absorption & Denver \\
& Cycles & Ben A. Phillips, President \\
& & Phillips Engineering \\
Secember 2 & Research Opportunities in & St. Joseph, Mich. \\
& Civil Defense & Jiri Nehnevajsa, Professor \\
December 3 & American Public Opinion and & University of Pittsburgh \\
& Civil Defense & Jiri Nehnevajsa, Professor \\
December 16 & Behavioral and Social Aspects & University of Pittsburgh \\
& of Energy: A Preview of & Paul C. Stern \\
& the National Academy Report & National Academy of Sciences \\
& Washington, D.C. \\
December 17 & Structure of Incentives and & Malcolm Gillis \\
& Risk Sharing in Petroleum & Harvard Institute \\
& Agreements Between Companies & for International \\
& and Governments: An Inter- & Development, Harvard \\
& national Perspective &
\end{tabular}


INVTTED SPEAKERS icoutinged)

\begin{tabular}{|c|c|c|}
\hline Date & Subject & Speaker \\
\hline $\begin{array}{c}\text { February 14, } \\
1983\end{array}$ & Risk and Culture & $\begin{array}{l}\text { Aaron Wildavsky } \\
\text { University of California at } \\
\text { Berkeley }\end{array}$ \\
\hline February 14 & $\begin{array}{l}\text { The Politics of Mistrust: } \\
\text { Estimating American Oil and } \\
\text { Gas Resources }\end{array}$ & $\begin{array}{l}\text { Aaron Wildavsky } \\
\text { University of Californis at } \\
\text { Berkeley }\end{array}$ \\
\hline March 7 & $\begin{array}{l}\text { The Role of Energy Data and } \\
\text { Technical Information in } \\
\text { Policy Formulation for } \\
\text { Developing Countries }\end{array}$ & $\begin{array}{l}\text { Miedi-Himie Neufville } \\
\text { Ministry of Lands, } \\
\text { Mines, and Energy } \\
\text { Government of Liberia } \\
\text { Monrovia, Liberia }\end{array}$ \\
\hline May 4 & $\begin{array}{l}\text { Energy and Human Aspects } \\
\text { of Integration of Day- } \\
\text { light and Electric Light } \\
\text { in Buildings }\end{array}$ & $\begin{array}{l}\text { E. M. Ne'eman, Professor } \\
\text { Eucrgy \& Environment Division } \\
\text { Lawrence Berkeley Laboratory } \\
\text { (on leave from Israel } \\
\text { Institute of Technology) }\end{array}$ \\
\hline May 19 & $\begin{array}{l}\text { Class B Monitoring of } \\
\text { Homes Using a 24-Channel } \\
\text { Data Recorder }\end{array}$ & $\begin{array}{l}\text { John Hill, Tom Hartman, } \\
\text { and G. B. Graves } \\
\text { ESG Company } \\
\text { Atlanta }\end{array}$ \\
\hline May 27 & $\begin{array}{l}\text { Overview on Hot Water } \\
\text { District Heating in } \\
\text { Sweden }\end{array}$ & $\begin{array}{l}\text { Peter Margen } \\
\text { Studsvik Laboratory } \\
\text { Sweden }\end{array}$ \\
\hline June 8-9 & $\begin{array}{l}\text { Evaluation Research and } \\
\text { Technology Transfer }\end{array}$ & $\begin{array}{l}\text { Todd R. LaPorte, Professor } \\
\text { Institute of Government } \\
\text { Studies, University of } \\
\text { California, Berkeley }\end{array}$ \\
\hline July 22 & $\begin{array}{l}\text { Usage Under a Permanent Tirm -of- } \\
\text { Day Electricity Pricing } \\
\text { Schedule }\end{array}$ & $\begin{array}{l}\text { Jerry A. Hausman } \\
\text { Massachusetts Institute } \\
\text { of Technology, Cambridge }\end{array}$ \\
\hline August 17 & Three Types of Risk Analysis & $\begin{array}{l}\text { Jerome R. Ravetz } \\
\text { University of Leeds } \\
\text { Leeds, United Kingdom }\end{array}$ \\
\hline August 18 & $\begin{array}{c}\text { Insurance as the Third Mode } \\
\text { of Technology Regulation }\end{array}$ & $\begin{array}{l}\text { Jerome R. Ravetz } \\
\text { University of Leeds } \\
\text { Leeds, United Kingdom }\end{array}$ \\
\hline August 29 & $\begin{array}{l}\text { Public Attitudes Toward Siting } \\
\text { of Nuclear Power Plants }\end{array}$ & $\begin{array}{l}\text { William R. Freudenburg } \\
\text { Washington State University } \\
\text { Pullman, Wash. }\end{array}$ \\
\hline August 30 & $\begin{array}{l}\text { Needed Improvements in Social } \\
\text { Impact Assessment Methodologies }\end{array}$ & $\begin{array}{l}\text { William F. Freudenburg } \\
\text { Washington State University } \\
\text { Pullman, Wash. }\end{array}$ \\
\hline
\end{tabular}




\subsection{STUDENT PAPERS}

Surjaseputra, Hanindijo, Earlham College, Richmond, Ind., student in the GLCA/ACM program, The Market Potential Estimations for Residential Water Heating Technologies, informal report.

Watson, Regina, DePauw University, Greencastle, Ind., student in the GLCA/ACM program, The Utility Segment of the United States Coal Market, informal report.

\subsection{FINANCIAL STATEMENT AND PERSONNEL SUMMARY}

The following charts provide an outline of the work of the Energy Division. The first chart is a listing of sponsors, expenditures, and commitments of the scientific staff, and the second shows a division of personnel by discipline.

\section{ENERGY DIVISION SPONSORS, EXPENDTURES, AND COMMITMENTS} OF SCTENTIFIC STAFT FOR FY 1983

\begin{tabular}{|c|c|c|c|c|c|}
\hline \multirow[b]{2}{*}{ Sponsor } & \multirow{2}{*}{$\begin{array}{l}\text { Expendi- } \\
\text { tures } \\
\left(10^{3} s\right)\end{array}$} & \multicolumn{2}{|c|}{$\begin{array}{l}\text { Scientific staff } \\
\text { (person-years) }\end{array}$} & \multirow{2}{*}{$\begin{array}{l}\text { Direct } \\
\text { person- } \\
\text { year } \\
\text { costs } \\
\left(10^{3} 5\right)\end{array}$} & \multirow{2}{*}{$\begin{array}{l}\text { Subcontract } \\
\text { costs } \\
\text { with } \\
\text { overhezde } \\
\left(10^{3} \mathrm{~s}\right)\end{array}$} \\
\hline & & $\begin{array}{l}\text { Energy } \\
\text { Division }\end{array}$ & $\begin{array}{c}\text { Other } \\
\text { divisions }\end{array}$ & & \\
\hline \multicolumn{6}{|c|}{ Department of Energy Work } \\
\hline $\begin{array}{l}\text { Conservation and Renewable Energy } \\
\text { Buildings and Community Systems } \\
\text { Electric Energy Systems } \\
\text { Gecthermal } \\
\text { Industrial } \\
\text { Multi-sector } \\
\text { Solar energy } \\
\text { State/local programs } \\
\text { Transportation }\end{array}$ & $\begin{array}{r}9,469 \\
3,513 \\
134 \\
603 \\
467 \\
184 \\
454 \\
196\end{array}$ & $\begin{array}{r}28.7 \\
6.3 \\
1.0 \\
2.5 \\
2.3 \\
1.3 \\
4.6 \\
1.3\end{array}$ & $\begin{array}{l}6.2 \\
1.2 \\
0.0 \\
1.7 \\
0.0 \\
0.0 \\
0.0 \\
0.0\end{array}$ & $\begin{array}{r}3,275 \\
729 \\
117 \\
369 \\
220 \\
140 \\
386 \\
122\end{array}$ & $\begin{array}{r}4,830 \\
2,485 \\
0 \\
86 \\
167 \\
13 \\
86 \\
34\end{array}$ \\
\hline Transportation & 15,020 & 48.0 & 9.1 & 5,358 & 7,701 \\
\hline $\begin{array}{l}\text { Economic Regulatory Administration } \\
\text { Office of Special Counsel for Compliance }\end{array}$ & 8 & 0.0 & 0.0 & 1 & 5 \\
\hline Energy Information Administration & 4,835 & 12.3 & 1.8 & 1,366 & 3,192 \\
\hline \multirow[t]{2}{*}{$\begin{array}{l}\text { Energy Research } \\
\text { Office of Energy Research } \\
\text { Office of Fusion Energy }\end{array}$} & $\begin{array}{r}28 \\
270 \\
\end{array}$ & $\begin{array}{l}0.1 \\
1.2\end{array}$ & $\begin{array}{l}0.0 \\
0.8\end{array}$ & $\begin{array}{r}10 \\
225\end{array}$ & $\begin{array}{r}16 \\
0\end{array}$ \\
\hline & 298 & 1.3 & 0.8 & 235 & 16 \\
\hline $\begin{array}{l}\text { Envirosmental Protection, Safety and } \\
\text { Emergency Preparedness }\end{array}$ & 999 & 3.9 & 0.0 & 396 & 490 \\
\hline Federal Energy Regulatory Commission & 141 & 1.2 & 0.0 & 129 & 0 \\
\hline \multirow[t]{2}{*}{$\begin{array}{l}\text { Fossil Energy } \\
\text { Office of Coal Utilization } \\
\text { Office of Oil, Gas, Shale, and Coal Liquids } \\
\text { Planning and Eavironment Division }\end{array}$} & $\begin{array}{r}84 \\
161 \\
470\end{array}$ & $\begin{array}{l}0.0 \\
1.0 \\
2.0\end{array}$ & $\begin{array}{l}0.4 \\
0.5 \\
0.3\end{array}$ & $\begin{array}{l}38 \\
156 \\
290\end{array}$ & $\begin{array}{r}07 \\
0 \\
141\end{array}$ \\
\hline & 715 & 3.0 & 1.2 & 484 & 208 \\
\hline
\end{tabular}


SPONSORS, EXPENDTIURSS, AND COMMIMMENIS (contined)

\begin{tabular}{|c|c|c|c|c|c|}
\hline \multirow[b]{2}{*}{ Sponsor } & \multirow{2}{*}{$\begin{array}{c}\text { Expendi- } \\
\text { tures } \\
\left(10^{3} \$\right)\end{array}$} & \multicolumn{2}{|c|}{$\begin{array}{l}\text { Scientific staff } \\
\text { (person-years) }\end{array}$} & \multirow{2}{*}{$\begin{array}{c}\text { Direct } \\
\text { person- } \\
\text { year } \\
\text { costs } \\
\left(10^{3} s\right)\end{array}$} & \multirow{2}{*}{$\begin{array}{l}\text { Subcontract } \\
\text { costs } \\
\text { with } \\
\text { overbead }^{c} \\
\left(10^{3} \$\right)\end{array}$} \\
\hline & & $\begin{array}{l}\text { Energy } \\
\text { Division }\end{array}$ & $\begin{array}{c}\text { Other } \\
\text { divisions" }\end{array}$ & & \\
\hline Management and odministration & 48 & 0.3 & 0.0 & 48 & $\mathbf{0}$ \\
\hline \multirow[t]{2}{*}{$\begin{array}{l}\text { Nuclear Energy } \\
\text { Defense waste management } \\
\text { Uranium earichment }\end{array}$} & $\begin{array}{l}417 \\
150 \\
\end{array}$ & $\begin{array}{l}3.1 \\
0.2 \\
\end{array}$ & $\begin{array}{l}0.2 \\
0.0 \\
\end{array}$ & $\begin{array}{r}367 \\
19 \\
\end{array}$ & $\begin{array}{r}37 \\
0 \\
\end{array}$ \\
\hline & 567 & 3.3 & 0.2 & 386 & 37 \\
\hline Policy, Planning and Analysis & 55 & C.1 & 0.0 & 13 & 38 \\
\hline \multirow[t]{2}{*}{$\begin{array}{l}\text { Bonneville Power Admigistration } \\
\text { Oak Ridge Operations Office } \\
\text { San Francisco Operations Office }\end{array}$} & $\begin{array}{r}358 \\
187 \\
90\end{array}$ & $\begin{array}{l}0.9 \\
0.9 \\
0.7\end{array}$ & $\begin{array}{l}0.0 \\
0.1 \\
0.0\end{array}$ & $\begin{array}{r}124 \\
111 \\
86\end{array}$ & $\begin{array}{r}129 \\
10 \\
0\end{array}$ \\
\hline & 635 & 2.5 & 0.1 & 321 & 139 \\
\hline $\begin{array}{l}\text { Argonne National Laboratory } \\
\text { Batteile Pacific Northwest Laboratory } \\
\text { Clinch Rivet Breoder Reactor Project Office }\end{array}$ & $\begin{array}{r}25 \\
14 \\
194\end{array}$ & $\begin{array}{l}0.2 \\
0.1 \\
1.6\end{array}$ & $\begin{array}{l}0.0 \\
0.0 \\
0.0\end{array}$ & $\begin{array}{r}20 \\
10 \\
155\end{array}$ & $\begin{array}{r}0 \\
0 \\
16\end{array}$ \\
\hline Clinch River Breoder Reactor Project Office & 233 & 1.9 & O.C & 185 & 16 \\
\hline Total DOE work & 23.554 & 77.8 & 13.1 & 8,922 & 11,842 \\
\hline
\end{tabular}

Other Federal Agencies Work

Nuclear Regulatory Commission

Office of Nuclear Material! Safety

and Safeguards

Office of Nuclear Reactor Regulation

Office of Facility Operations

Office of Health, Siting and Wasie

Management

General and other

\begin{tabular}{rrrrr}
836 & 4.3 & 0.5 & 533 & 189 \\
481 & 1.5 & 0.1 & 195 & 38 \\
228 & 1.2 & 0.4 & 182 & 17 \\
390 & 1.0 & 0.0 & 113 & 195 \\
102 & 0.6 & 0.0 & 72 & 0 \\
\hline 2,037 & 8.6 & $\frac{1.0}{n n}$ & $\frac{1,095}{439}$
\end{tabular}

Department of the Air Force

Ballistic Missile Office

Engineering and Services Center

Military Traffic Management Command

\begin{tabular}{|c|c|c|c|c|}
\hline 42 & 0.3 & 0.0 & 27 & 5 \\
\hline 102 & 0.4 & 0.0 & 44 & 26 \\
\hline 3 & 0.0 & 0.0 & 2 & 0 \\
\hline 147 & (3) & & & \\
\hline
\end{tabular}

Department of the Army

Civilian Personnel Center

Materiel Development and Readiness

Command

Construction Engineering Research

Laboratory

Facilities Engineering Support Agency

\begin{tabular}{rrrrr}
2 & 0.0 & 0.0 & 1 & 0 \\
404 & 2.0 & 0.0 & 210 & 83 \\
29 & 0.2 & 0.0 & 24 & 0 \\
45 & 0.3 & 0.0 & 37 & 0 \\
\hline 480 & $\frac{0.5}{2.5}$ & 0.0 & $\frac{272}{83}$
\end{tabular}

Department of the Interior Bureau of Land Managemert

Bureau of Mines

$\begin{array}{rrr}71 & 0.2 & 0.0 \\ 8 & 0.0 & 0.0\end{array}$

29 
SPONSORS, EXPENDITURSS, AND COMMIMMENTS (contined)

\begin{tabular}{|c|c|c|c|c|c|}
\hline \multirow[b]{2}{*}{ Sponsor } & \multirow{2}{*}{$\begin{array}{c}\text { Expendi- } \\
\text { tures } \\
\left(10^{3} \$\right)\end{array}$} & \multicolumn{2}{|c|}{$\begin{array}{l}\text { Scientific staff } \\
\text { (person-years) }\end{array}$} & \multirow{2}{*}{$\begin{array}{c}\text { Direct } \\
\text { person- } \\
\text { year } \\
\text { costsb } \\
\left(10^{3} 5\right)\end{array}$} & \multirow{2}{*}{$\begin{array}{l}\text { Subcontract } \\
\text { costs } \\
\text { with } \\
\text { overhead } \\
\left(10^{3} 5\right)\end{array}$} \\
\hline & & $\begin{array}{l}\text { Energy } \\
\text { Division }\end{array}$ & $\begin{array}{c}\text { Other } \\
\text { divisions }\end{array}$ & & \\
\hline Minerals Management Service & 232 & 1.5 & 0.6 & 187 & 32 \\
\hline \multirow[t]{2}{*}{ Office of Surface Mining } & 511 & 1.1 & 0.0 & 128 & 322 \\
\hline & 822 & 2.8 & 0.6 & 348 & 386 \\
\hline Department of Justice & 46 & 0.0 & 0.0 & $\mathbf{0}$ & 38 \\
\hline Department of Labor & 6 & 0.0 & 0.0 & 1 & 0 \\
\hline \multicolumn{6}{|l|}{ Department of the Navy } \\
\hline Naval Air Systems Command & 258 & 0.2 & 0.0 & 26 & 228 \\
\hline David W. Taylor Naval Ship R\&D Center & 194 & 0.2 & 0.6 & 72 & 52 \\
\hline $\begin{array}{l}\text { Naval Weapons Center } \\
\text { Ni.val Weapons Engineering Support }\end{array}$ & 24 & 0.1 & 0.0 & 9 & 15 \\
\hline Activity & 587 & 1.0 & 0.0 & 110 & 363 \\
\hline Marine Corps & 163 & 0.1 & 0.0 & 15 & 131 \\
\hline Naval Civil Engineerirgg Laboratory & 64 & 0.6 & 0.0 & 59 & 0 \\
\hline Naval Material Command & 6 & 0.1 & 0.0 & 6 & $\mathbf{0}$ \\
\hline Naval Military Personnel Command & 274 & 2.4 & 0.0 & 206 & 29 \\
\hline Naval Sea Systems Command & 287 & 0.0 & 0.0 & 8 & 272 \\
\hline Naval Supply Systems Command & 9 & 0.0 & 0.0 & 1 & 0 \\
\hline Navy Aviation Logistics Center & 7 & 0.1 & 0.0 & 7 & 0 \\
\hline Navy Management Systems Support Office & 1 & 9.0 & 0.0 & $\mathbf{0}$ & 0 \\
\hline \multirow[t]{2}{*}{ Navy Regional Data Automation Center } & 1,045 & 0.8 & 0.0 & 97 & 865 \\
\hline & 2,919 & 5.6 & 0.6 & $\overline{616}$ & 1,955 \\
\hline $\begin{array}{l}\text { Department of State--Agency for } \\
\text { International Development }\end{array}$ & 201 & 1.0 & 0.0 & 113 & 10 \\
\hline Synthetic Fuels Corporation & 33 & 0.2 & 0.0 & 31 & 0 \\
\hline Tennessee Valley Authority & 33 & 0.3 & 0.0 & 31 & 0 \\
\hline Environmental Protection Agency & 38 & 0.1 & 0.3 & 34 & 0 \\
\hline Department of Transportation & 299 & 1.5 & 0.0 & 128 & 62 \\
\hline Federal Emergency Management Agency & 451 & 2.7 & 0.3 & 288 & 22 \\
\hline Total other federal agencies work & 7,510 & 26.0 & 2.8 & 3,030 & 3,006 \\
\hline \multicolumn{6}{|c|}{ Privalr Organizations Work } \\
\hline Electric Power Research Institute & 125 & 1.2 & 0.0 & 111 & 3 \\
\hline Total thi-DOE work & 7,615 & 27.2 & 2.8 & 3,141 & 3,009 \\
\hline Total DOE work & 23,554 & 77.8 & 13.1 & 8,922 & 11,842 \\
\hline Total Energy Division work & 31,189 & 105.0 & 15.9 & 12,063 & 14,851 \\
\hline
\end{tabular}

'Includes other research and support divisions such as I'lant and Equipment Division, Instrumentation and Controls Division, Y-12 Plant Crafts and Maintenance, and Central Engineering Services.

bIncludes technical staff labor costs for Energy Dirision and other research and support divisions and Laboratory overhead.

'Includes Laboratory overhead $v$ 'here it app!ies but excludes the subcontract increniental tax of $\$ 194,000$ charged to the Energy Division during FY 1983. This tax is to pay for the ccsts of procurement, auditing, and accounting. 


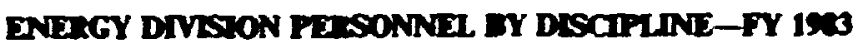

October 1983

\begin{tabular}{|c|c|c|c|c|c|c|c|c|}
\hline Discipline & EIS & RUS & EAS & DAS & ERRS & P\&P & $\begin{array}{l}\text { Adminis- } \\
\text { tration }\end{array}$ & Toeal \\
\hline \multicolumn{9}{|c|}{ Professional } \\
\hline \multicolumn{9}{|l|}{ Social sciences } \\
\hline Anthropologists & & 1.0 & & & & & & 1.0 \\
\hline Anchitects & & 1.0 & & & 1.0 & & & 2.0 \\
\hline Ecoacmists & & & 15.0 & & & & & 15.0 \\
\hline Geographess & .0 & 8.5 & & & & 1.0 & & 10.5 \\
\hline Ph:losophers & & 0.5 & & & & & & 0.5 \\
\hline Planners & & 1.0 & & 1.0 & & & & 2.0 \\
\hline Political scientists & & 20 & & & & & & 20 \\
\hline Psychologists & & 1.0 & & & & & & 1.0 \\
\hline Science eduation & & & & & 0.5 & & & 0.5 \\
\hline Sociologists & & 2.0 & & 1.5 & & & & 3.5 \\
\hline Other & & 1.0 & & & & & & 1.0 \\
\hline Toul social sciences & & & & & & & & 39.0 \\
\hline \multicolumn{9}{|l|}{ Physical and life sciences } \\
\hline Biologists & 3.0 & 0.5 & & 20 & & & & 5.5 \\
\hline Chemists & 4.0 & & & 2.0 & 1.0 & & & 7.0 \\
\hline Ecotogists & 1.0 & & & & & & & 1.0 \\
\hline Geologists & 4.0 & & & & & & & 4.0 \\
\hline Math maticians/statisticians & & 1.0 & & 6.0 & 1.0 & & & 8.0 \\
\hline Meteorologists & 3.0 & & & & & & & 3.0 \\
\hline Physicists & & 2.0 & & 1.0 & 5.0 & 1.0 & & 9.0 \\
\hline $\begin{array}{l}\text { Toeal physical and } \\
\text { life sciences }\end{array}$ & & & & & & & & 37.5 \\
\hline \multicolumn{9}{|l|}{ Engineering sciences } \\
\hline Chemical engineers & 3.C & 1.0 & & 2.0 & 5.0 & & 1.0 & 12.0 \\
\hline Civil engineers & & 1.0 & & & & & & 1.0 \\
\hline Electrical engineers & 1.0 & 1.0 & & & 6.0 & & & 8.0 \\
\hline Engineering physicists & & & & & 1.0 & & & 1.0 \\
\hline Engineering scientists & & 1.0 & & & 2.0 & & & 3.0 \\
\hline Industrial engineen & & & & 1.0 & & & & i.c \\
\hline Mechanical engineers & 5.0 & 2.0 & & 3.0 & 13.0 & 1.0 & & 24.0 \\
\hline Nuclear enginoers & & & & & & 1.0 & & 1.0 \\
\hline Operations rescarch & & & & 1.0 & & & & 1.0 \\
\hline Systems analysts & & & & 1.0 & & & & 1.0 \\
\hline Other & & & & & 1.0 & & & 1.0 \\
\hline Total engineering sciences & & & & & & & & 54.0 \\
\hline
\end{tabular}

Administrotive and rechnical suprort

Accountants

Accounting clerks

Administrative assistants

Data center analysts

1.0

1.0

Librarians

2.0

1.0

$1.0 \quad 10$

$1.0 \quad 1.0$

1.0

$$
\begin{aligned}
& 3.0 \\
& 1.0
\end{aligned}
$$


183

ENERGY DIVISLON PERSONNEL (centinad)

\begin{tabular}{|c|c|c|c|c|c|c|c|c|}
\hline Discipline & EIS" & RUS & EAS & DAS & ERRS & P\&P & $\begin{array}{l}\text { Adminis- } \\
\text { tration }\end{array}$ & Toul \\
\hline $\begin{array}{l}\text { Secretaries } \\
\text { Technicians }\end{array}$ & 4.5 & 6.5 & 3.5 & 5.5 & $\begin{array}{l}8.0 \\
4.0\end{array}$ & 1.0 & 3.5 & $\begin{array}{r}32.5 \\
4.0\end{array}$ \\
\hline $\begin{array}{l}\text { Total administrative and } \\
\text { technical support }\end{array}$ & & & & & & & & 43.5 \\
\hline Total & 29.5 & 37.0 & 18.5 & 29.0 & 48.5 & 5.0 & 6.5 & 174.0 \\
\hline
\end{tabular}




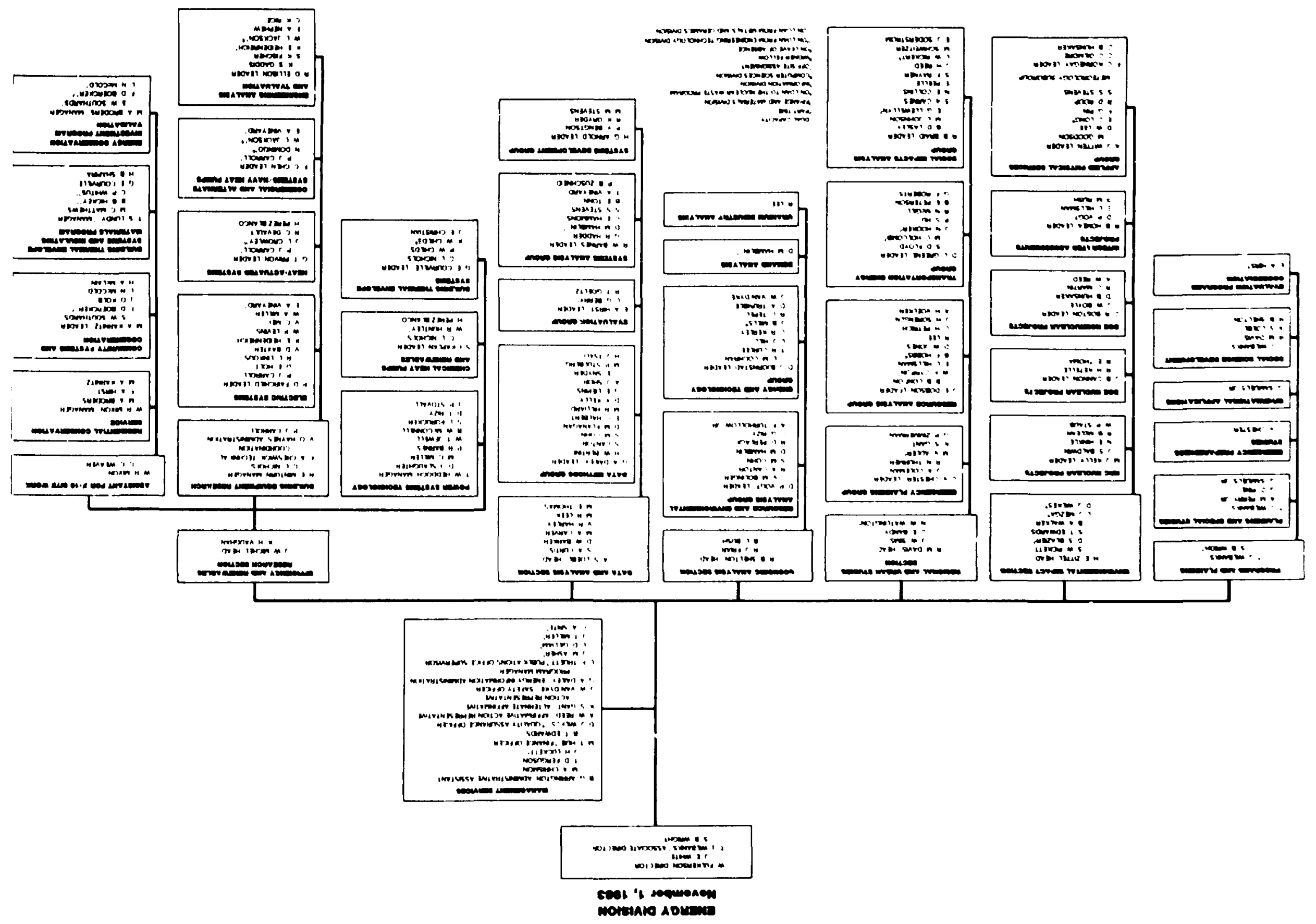




\section{Internal Uistribution}

1. R. L. Absher

2. M. V. Adler

3-7. H. G. Arnold

8. B. G. Arrington

9. J. M. Asher

10. T. L. Ashwood

11. D. W. Barker

12. P. R. Barnes

13. V. D. Baxter

14. L. G. Berry

15. D. J. Bjornstad

16. D. S. Blazier

17. J. L. Bledsoe

18. C. R. Boston

19. H. I. Bowers

20. R. B. Braid

21. M. A. Broders

22. M. A. Brown

23. K. C. Brunson

24. D. W. Burton

25. B. L. Bysh

26. J. B. Cannon

27. R. A. Cantor

28. S. Cantor

29. S. A. Carnes

30. P. J. Carroll

31. F. C. Chen

32. C. V. Chester

33. R. O. Chester

34. M. A. Chrismon

35. J. E. Christian

36. L. G. Christophorou

37. L. M. Cochran

38. S. M. Cohn

39. E. D. Copenhaver

40. G. E. Courville

41. C. C. Coutant

42. K. E. Cowser

43. T. R. Curlec

44. S. A. Curtis
45. G. A. Dailey

46. S. J. Dale

47. R. M. Davis

48. R. C. DeVault

49. N. Domingo

50. R. C. Durfee

51. B. T. Edwards

52. R. D. Ellison

53. C. J. Emerson

54. L. D. Eyman

55. T. A. Ferguson

56. S. K. Fischer

57. R. J. Friar

58. W. Fulkerson

59. K. S. Gant

60. L. D. Gilliam

61. C. C. Gilmore

62. P. A. Gnadt

63. R. T. Goeltz

64. D. L. Greene

65. R. K. Gryder

66. G. R. Hadder

67. E. C. Halbert

68. D. M. Hamblin

69. C. E. Hammons

70. V. O. Haynes

71. T. L. Hebble

72. D. M. Hetrick

73. S. G. Hildebrand

74. M. R. Hilliard

75. E. L. Hillsman

76. N. E. Hinkle

77. E. A. Hirst

78. M. C. Holcomb

79. P. S. T. Hu

80. T. L. Hudson

81. M. T. Huie

82. D. B. Hunsaker

83. W. L. Jackson

84. M. L. Johnson 
85. S. 1. Kaplan

86. R. J. Kedl

87. C. D. Kelly

88. D. Y. Kelly

89. C. R. Kerley

90. R. H. Ketelle

91. J. O. Kolb

92. C. H. Krause

93. M. A. Kuliasha

94. D. W. Lee

95. R. Lee

96. M. R. Leek

97. A. S. Loebl

98. T. S. Lundy

99. J. F. Martin

100. L. N. McCold

101. B. W. McConnell

102. D. L. McElroy

1C3. R. N. McGill

104. H. A. McLain

105. V. C. Mei

106. L. J. Mezga

107. J. W. Michel

108. M. C. Miller

109. R. E. Minturn

110-114. W. R. Mixon

115. E. A. Nephew

116. C. L. Nichols

1'7. W. W. Parker

118 E. B. Peelle

119. R. D. Perlack

120. A. M. Perry

121. B. E. Peterson

122. C. H. Petrich

123. S. W. Pickett

124. F. G. Pin

125. G. D. Pine

126. S. L. Purucker

127. S. F. Rayner

128. T. W. Raddoch

129. J. H. Reed

130. S. A. Reed

131. D. E. Reichle

132. C. K. Rice
133. L. W. Rickert

134. C. G. Rizy

135. D. T. Rizy

136. G. F. Roberts

137. R. D. Roop

138. R. M. Rush

139. G. Samuels, Jr.

140. M. Schweitzer

141. R. B. Shelton

142. D. J. Slaughter

143. E. J. Soderstrom

144. J. H. Sorensen

145. C. A. Srite

146. W. P. Staub

147. M. M. Stevens

148. R. A. Stevens

149. J. P. Stovall

i50. L. E. Stratton

151. M. P. Stulberg

152. R. C. Tepel

153. R. E. Thoma

154. M. E. Thomas

155. B. E. Tonn

156. L. F. Truett

157. H. J. Tsao

158. K. H. Vaughan

159. E. A. Vineyard

160. A. H. Voelker

161. D. P. Vogt

162. P. J. Walsh

163. C. R. Weisbin

164. R. L. Wendt

165. C. D. West

166. G. W. Westley

167. J. E. White

168. C. Whitmire

169. T. J. Wilbanks

170. B. Y. Wilkes

171. D. J. Wilkes

172. D. L. Wilson

173. A. J. Witten

174. S. B. Wright

175. T. Wrigit

176. S. L. Youn, 
177. G. P. Zimmerman

178. K. W. Zimmerman

179. H. E. Z: II

180. P. B. Zuschneid

181-182. Central Research Library
183-184. Document Reference Section

185. Emergency Technology Library

186-188. Laboratory Records Department

189. Laboratory Records Department-RC

190. ORNL Patent Section

\section{Extermal Distribution}

191-192. Office of the Assistant Manager for Energy Research and Development, DOE-ORO

193. MERT Division Library, ORAU

194-273. Office of Information Services, ORAU

274-484. Given distribution as shown in DOE/TIC-4500 under General, Miscellaneous, and Progress Reports, Nuclear and Nonnuclear Categories (25 copies, NTIS)

485-1085. Energy Division External Distribution 